\title{
WestVirginiaUniversity
}

THE RESEARCH REPOSITORY @ WVU

Graduate Theses, Dissertations, and Problem Reports

2005

\section{Investigation of soil-geosynthetic interface properties}

Jonathan Niemiec

West Virginia University

Follow this and additional works at: https://researchrepository.wvu.edu/etd

\section{Recommended Citation}

Niemiec, Jonathan, "Investigation of soil-geosynthetic interface properties" (2005). Graduate Theses, Dissertations, and Problem Reports. 4180.

https://researchrepository.wvu.edu/etd/4180

This Thesis is protected by copyright and/or related rights. It has been brought to you by the The Research Repository @ WVU with permission from the rights-holder(s). You are free to use this Thesis in any way that is permitted by the copyright and related rights legislation that applies to your use. For other uses you must obtain permission from the rights-holder(s) directly, unless additional rights are indicated by a Creative Commons license in the record and/ or on the work itself. This Thesis has been accepted for inclusion in WVU Graduate Theses, Dissertations, and Problem Reports collection by an authorized administrator of The Research Repository @ WVU. For more information, please contact researchrepository@mail.wvu.edu. 


\title{
Investigation of Soil-Geosynthetic Interface Properties
}

\author{
By \\ Jonathan Niemiec \\ Thesis submitted to the \\ College of Engineering and Mineral Resources \\ at West Virginia University \\ in partial fulfillment of the requirements \\ for the degree of \\ Master of Science \\ in \\ Civil Engineering
Hema Siriwardane, Ph.D., Chair
Udaya Halabe, Ph.D.
Roger Viadero, Ph.D. \\ Department of Civil and Environmental Engineering \\ Morgantown, West Virginia
2005
}

Keywords: Interface Properties, Geosynthetics, Pullout Test, Direct Shear Test 


\title{
ABSTRACT \\ Investigation of Soil-Geosynthetic Interface Properties
}

\author{
Jonathan Niemiec
}

The purpose of this study was to investigate and gain a better understanding of soil-geosynthetic interface properties. By using two pullout devices, designed specifically for this research study, and a direct shear device the behavior of soilgeosynthetic interfaces and pullout resistance has been investigated. The two pullout devices contained pullout boxes with dimensions 18 " $\times 12^{\prime \prime} \times 6$ " $(45.7 \mathrm{~cm} \times 30.5 \mathrm{~cm} \times$ $15.2 \mathrm{~cm})$ and $48^{\prime \prime} \times 18^{\prime \prime} \times 6 "$ (122cm $\left.\times 45.7 \mathrm{~cm} \times 15.2 \mathrm{~cm}\right)$. Instrumentation for measuring load and displacement was completed. Normal stresses on the soil-geosynthetic interface were applied by using rubber airbags, which were built to fit the pullout devices. A clamping mechanism and guide system was designed to prevent synthetic/clamp separation and to avoid rotation of the specimen during testing. Experimental data was collected and compared for three soil types and three geosynthetic materials. Results show that the water content, geosynthetic properties, normal pressure and soil properties all have an effect on soil-geosynthetic interface behavior. 


\section{ACKNOWLEDGMENTS}

The author wishes to express a great appreciation to all who gave support in the process of this research project. A special thanks to Dr. Hema Siriwardane, graduate advisor and committee chairperson, for his assistance and guidance throughout this research project. Participation on the examining committee of Dr. Udaya Halabe and Dr. Roger Viadero is greatly appreciated. The author would also like to thank the Federal Highway Administration (FHWA) for providing financial support for this project entitled “Characterization, Evaluation and Implementation of Fiber Reinforced Polymer (FRP) Composites for Highway Infrastructure” through the Constructed Facilities Center (CFC) at West Virginia University. Finally, for the encouragement during the completion of this thesis the author would like to express gratitude to friends and family. 


\section{TABLE OF CONTENTS}

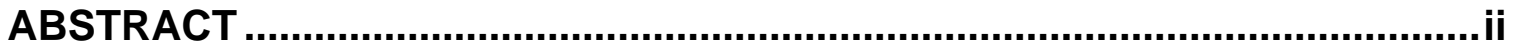

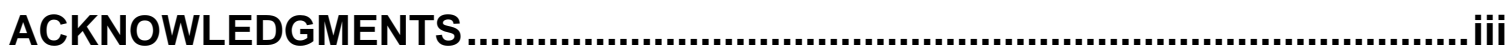

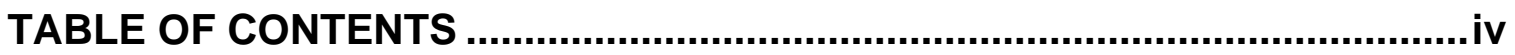

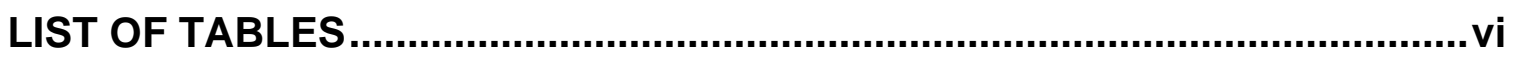

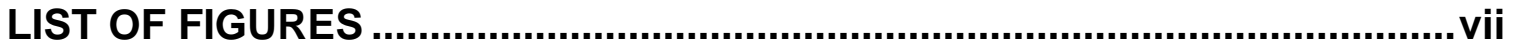

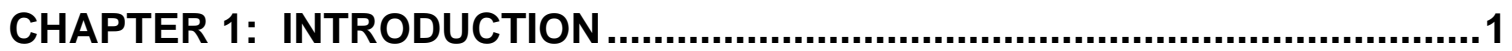

$1.1 \quad$ Background .................................................................................................................... 1

$1.2 \quad$ Direct Shear Testing Programs .................................................................................. 2

$1.3 \quad$ Pullout Testing Programs............................................................................................. 4

1.4 Applications of Geosynthetics in Transportation Infrastructure....................... 9

CHAPTER 2: EXPERIMENTAL APPARATUS …....................................11

$2.1 \quad$ Design of Pullout Boxes .......................................................................................... 11

2.2 Equipment used for Pullout Testing ....................................................................... 18

2.3 Instrumentation used for Pullout Testing............................................................... 24

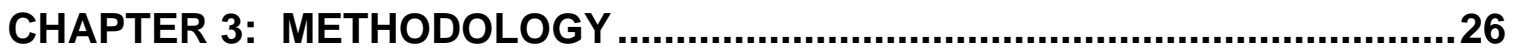

3.1 Direct Shear Testing ................................................................................................ 26

3.1.1 Material Selection for Direct Shear Testing …………………………......... 26

3.1.2 Placement of Materials for Direct Shear Testing.......................................... 34

3.1.3 Procedures for Direct Shear Testing ............................................................... 35

3.1.4 Calculations for Direct Shear Testing............................................................ 42

$3.2 \quad$ Pullout Testing ................................................................................................................ 44

3.2.1 Material Selection for Pullout Testing ........................................................... 45 
3.2.2 Placement of Materials for Pullout Testing ............................................. 45

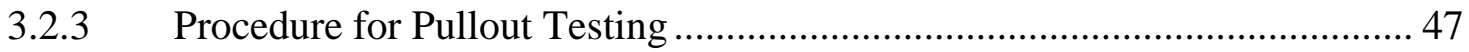

3.2.4 Calculations for Pullout Testing .......................................................... 48

CHAPTER 4: RESULTS AND DISCUSSION................................................50

4.1 Direct Shear Test Results and Discussion...................................................... 50

4.2 Effects of Geosynthetic Material Properties on Direct Shear Tests Results 100

4.3 Pullout Box A Test Results and Discussion .................................................. 103

4.4 Pullout Box B Test Results and Discussion.............................................. 165

4.5 Effects of Soil Properties on Pullout Test Results...................................... 166

4.6 Effects of Geosynthetic Properties on Pullout Test Results .......................... 181

4.7 Effects of Moisture Content on Pullout Test Results.................................... 193

4.8 Comparison of Direct Shear and Pullout Test Results................................. 205

CHAPTER 5: SUMMARY AND CONCLUSIONS .........................................212

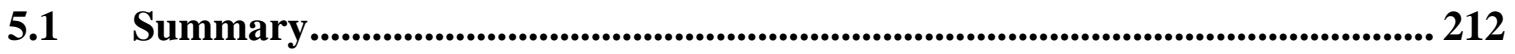

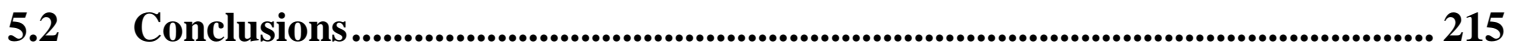

5.2.1 Conclusions for Direct Shear Test Results ............................................ 215

5.2.2 Conclusions for Pullout Test Results ...................................................... 215

5.2.3 Conclusions for the Comparison of Direct Shear and Pullout Test Results 216

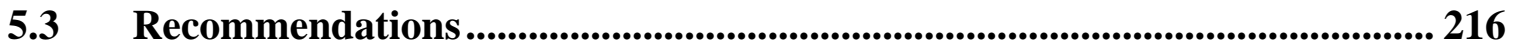

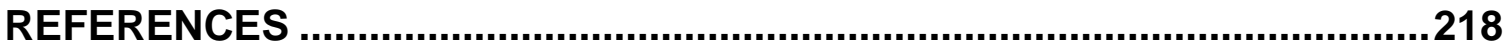




\section{LIST OF TABLES}

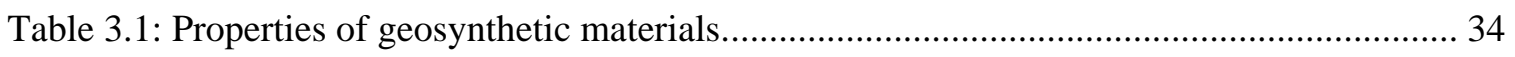

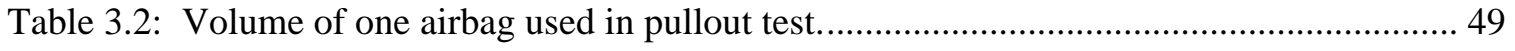

Table 4.1: Summary of direct shear test results and geosynthetic material properties................. 99

Table 4.2: Summary of pullout test results and geosynthetic material properties....................... 164

Table 5.1: Summary of direct shear and pullout test results with geosynthetic material properties 


\section{LIST OF FIGURES}

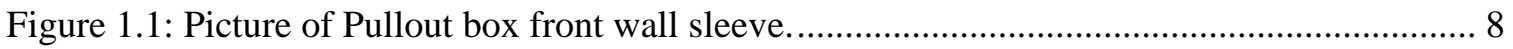

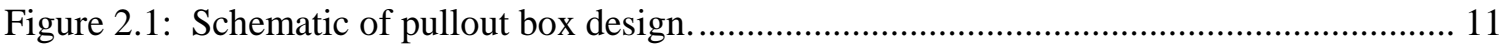

Figure 2.2: Dimetric view of displacement Finite Element model for pullout box A.................. 12

Figure 2.3: Profile view of displacement Finite Element model for pullout box A. .................... 13

Figure 2.4: Plan view of displacement Finite Element model for pullout box A......................... 14

Figure 2.5: Dimetric view of displacement Finite Element model for box B. ............................. 15

Figure 2.6: Profile view of displacement Finite Element model for box B.................................. 16

Figure 2.7: Plan view of Finite Element model showing displacement for box B...................... 17

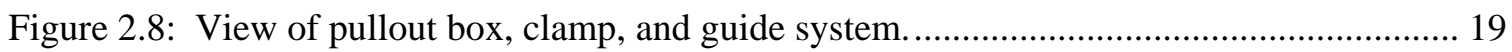

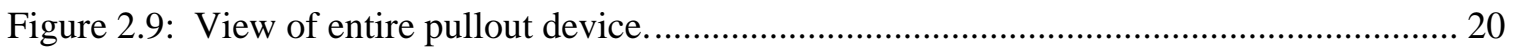

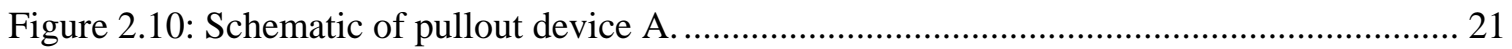

Figure 2.11: Schematic of pressurized air bag for pullout box A................................................. 22

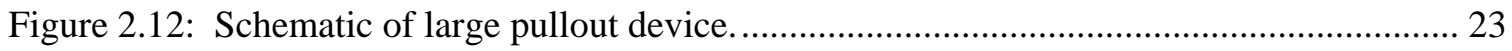

Figure 2.13: View of pullout device containing pullout box B.................................................. 24

Figure 2.14: (a) Calibration of load cell and voltmeter for pullout box A and (b) Calibration of

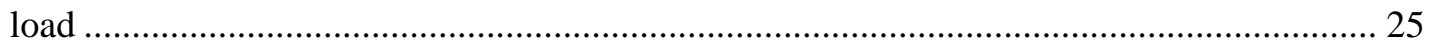

Figure 3.1: Grain Size Distribution for sand used in Direct Shear tests...................................... 28

Figure 3.2: Grain Size Distribution for silt used in Direct Shear tests. ....................................... 29

Figure 3.3: Grain Size Distribution for clay used in Direct Shear tests. ..................................... 30

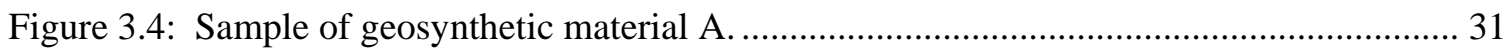

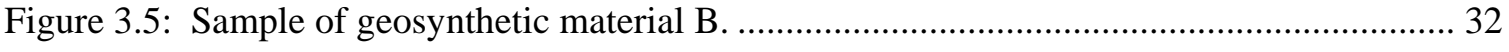

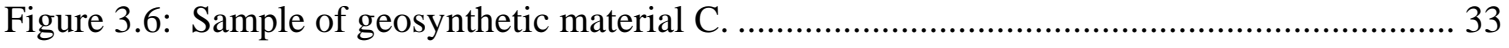

Figure 3.7: Shear box with mounting screws to present uniform gap......................................... 35

Figure 3.8: Shear box inside frame with framing screws tight................................................... 36

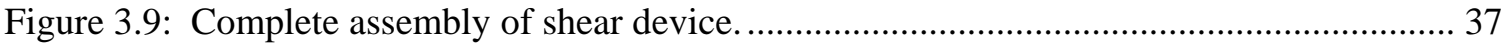

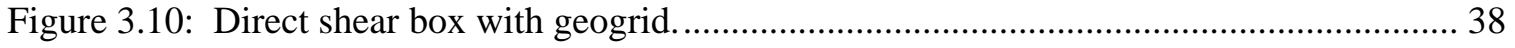

Figure 3.11: Direct shear box with geogrid clamped to frame..................................................... 39

Figure 3.12: Direct shear box with wood block and geotextile.................................................. 41

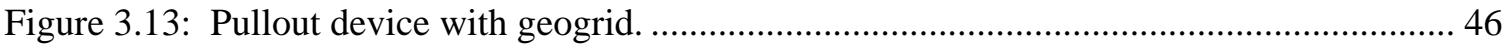

Figure 4.1: Direct shear test results for sand-sand interface at $\mathrm{S}_{\mathrm{n}}=35.3 \mathrm{kPa}$........................... 51

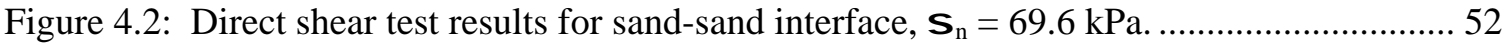


Figure 4.3: Direct shear test results for sand-sand interface, $\mathbf{S}_{\mathrm{n}}=103.9 \mathrm{kPa} \ldots \ldots \ldots \ldots \ldots \ldots \ldots \ldots \ldots . . . . . . . . . . . . . . .53$

Figure 4.4: Direct shear failure envelope, sand - sand interface. ….......................................... 54

Figure 4.5: Direct shear test results for material A-sand interface at $\mathrm{S}_{\mathrm{n}}=35.3 \mathrm{kPa} \ldots \ldots \ldots \ldots \ldots \ldots . . . . . . . . .55$

Figure 4.6: Direct shear test results for material A-sand interface at $\mathrm{S}_{\mathrm{n}}=69.6 \mathrm{kPa} \ldots \ldots \ldots \ldots \ldots \ldots \ldots . . . . . . . .56$

Figure 4.7: Direct shear test results for material A-sand interface at $\mathrm{S}_{\mathrm{n}}=103.9 \mathrm{kPa} \ldots \ldots \ldots \ldots \ldots \ldots . . . . . . .57$

Figure 4.8: Direct shear failure envelope for material A-sand interface. .................................... 58

Figure 4.9: Direct shear test results for material B-sand interface, $\mathrm{S}_{\mathrm{n}}=35.3 \mathrm{kPa} \ldots \ldots \ldots \ldots \ldots \ldots \ldots \ldots . . . . . . . . . .59$

Figure 4.10: Direct shear test results for material B-sand interface, $\mathrm{S}_{\mathrm{n}}=69.6 \mathrm{kPa} \ldots \ldots \ldots \ldots \ldots \ldots \ldots . . . . . . . .60$

Figure 4.11: Direct shear test results for material B-sand interface, $\mathrm{S}_{\mathrm{n}}=103.9 \mathrm{kPa} \ldots \ldots \ldots \ldots \ldots \ldots . . . . . . .61$

Figure 4.12: Direct shear failure envelope, material B - sand interface. …................................. 62

Figure 4.13: Direct shear test results, material C-sand interface, $\mathrm{S}_{\mathrm{n}}=35.3 \mathrm{kPa}$........................ 63

Figure 4.14: Direct shear test results, material C-sand interface, $\mathrm{S}_{\mathrm{n}}=69.6 \mathrm{kPa}$........................ 64

Figure 4.15: Direct shear test results, material C-sand interface, $\mathrm{S}_{\mathrm{n}}=103.9 \mathrm{kPa} . \ldots \ldots \ldots \ldots \ldots \ldots \ldots . . . . . . . . .65$

Figure 4.16: Direct shear failure envelope, material C - sand interface. ….................................. 66

Figure 4.17: Direct shear test results for sand-sand interface at $\sigma_{\mathrm{n}}=35.3 \mathrm{kPa}$ with $10 \%$ water

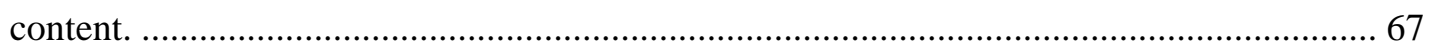

Figure 4.18: Direct shear test results for sand-sand interface at $\sigma_{\mathrm{n}}=69.6 \mathrm{kPa}$ with $10 \%$ water

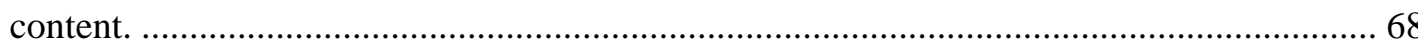

Figure 4.19: Direct shear test results for sand-sand interface at $\sigma_{\mathrm{n}}=103.9 \mathrm{kPa}$ with $10 \%$ water content.

Figure 4.20: Direct shear failure envelope for sand-sand interface with $10 \%$ water content....... 70

Figure 4.21: Direct shear test results for sand-sand interface at $\sigma_{\mathrm{n}}=35.3 \mathrm{kPa}$ with $15 \%$ water

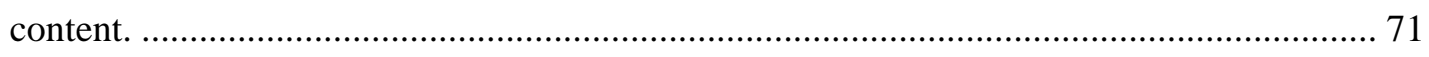

Figure 4.22: Direct shear test results for sand-sand interface at $\sigma_{\mathrm{n}}=69.6 \mathrm{kPa}$ with $15 \%$ water

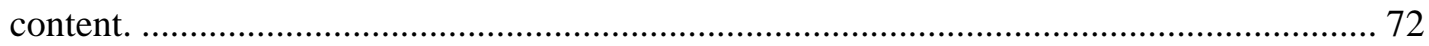

Figure 4.23: Direct shear test results for sand-sand interface at $\sigma_{\mathrm{n}}=103.9 \mathrm{kPa}$ with $15 \%$ water

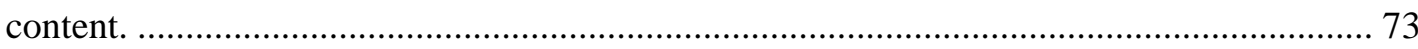

Figure 4.24: Direct shear failure envelope for sand-sand interface with 15\% water content....... 74 Figure 4.25: Direct shear test results for silt-silt interface at $\sigma_{\mathrm{n}}=35.3 \mathrm{kPa}$ with $0 \%$ water content. 
Figure 4.26: Direct shear test results for silt-silt interface at $\sigma_{\mathrm{n}}=69.6 \mathrm{kPa}$ with $0 \%$ water content.

Figure 4.27: Direct shear test results for silt-silt interface at $\sigma_{\mathrm{n}}=103.9 \mathrm{kPa}$ with $0 \%$ water content.

Figure 4.28: Direct shear failure envelope for silt-silt interface with $0 \%$ water content

Figure 4.29: Direct shear test results for silt-silt interface at $\sigma_{\mathrm{n}}=35.3 \mathrm{kPa}$ with $10 \%$ water content.

Figure 4.30: Direct shear test results for silt-silt interface at $\sigma_{\mathrm{n}}=69.6 \mathrm{kPa}$ with $10 \%$ water content.

Figure 4.31: Direct shear test results for silt-silt interface at $\sigma_{\mathrm{n}}=103.9 \mathrm{kPa}$ with $10 \%$ water content.

Figure 4.32: Direct shear failure envelope for silt-silt interface with $10 \%$ water content

Figure 4.33: Direct shear test results for silt-silt interface at $\sigma_{\mathrm{n}}=35.3 \mathrm{kPa}$ with $15 \%$ water content.

Figure 4.34: Direct shear test results for silt-silt interface at $\sigma_{\mathrm{n}}=69.6 \mathrm{kPa}$ with $15 \%$ water content.

Figure 4.35: Direct shear test results for silt-silt interface at $\sigma_{\mathrm{n}}=103.9 \mathrm{kPa}$ with $15 \%$ water content. 85

Figure 4.36: Direct shear failure envelope for silt-silt interface with 15\% water content 86

Figure 4.37: Direct shear test results for clay-clay interface at $\sigma_{\mathrm{n}}=35.3 \mathrm{kPa}$ with $0 \%$ water content.

Figure 4.38: Direct shear test results for clay-clay interface at $\sigma_{\mathrm{n}}=69.6 \mathrm{kPa}$ with $0 \%$ water content.

Figure 4.39: Direct shear test results for clay-clay interface at $\sigma_{\mathrm{n}}=103.9 \mathrm{kPa}$ with $0 \%$ water content. 89

Figure 4.40: Direct shear failure envelope for clay-clay interface with $0 \%$ water content. 90

Figure 4.41: Direct shear test results for clay-clay interface at $\sigma_{\mathrm{n}}=35.3 \mathrm{kPa}$ with $10 \%$ water content.

Figure 4.42: Direct shear test results for clay-clay interface at $\sigma_{\mathrm{n}}=69.6 \mathrm{kPa}$ with $10 \%$ water content.

Figure 4.43: Direct shear test results for clay-clay interface at $\sigma_{\mathrm{n}}=103.9 \mathrm{kPa}$ with $10 \%$ water content. 93

Figure 4.44: Direct shear failure envelope for clay-clay interface with 10\% water content. 
Figure 4.45: Direct shear test results for clay-clay interface at $\sigma_{\mathrm{n}}=35.3 \mathrm{kPa}$ with $15 \%$ water

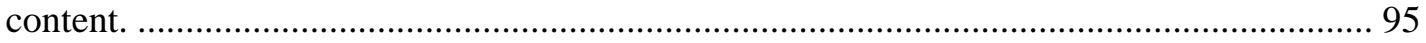

Figure 4.46: Direct shear test results for clay-clay interface at $\sigma_{\mathrm{n}}=69.6 \mathrm{kPa}$ with $15 \%$ water content.

Figure 4.47: Direct shear test results for clay-clay interface at $\sigma_{\mathrm{n}}=103.9 \mathrm{kPa}$ with $15 \%$ water content. 97

Figure 4.48: Direct shear failure envelope for clay-clay interface with 15\% water content. ....... 98 Figure 4.49: Direct shear test results for material A, B, and C-sand interface at $\mathrm{S}_{\mathrm{n}}=35.3 \mathrm{kPa} 100$ Figure 4.50: Direct shear test results for material A, B, and C-sand interface at $\mathrm{S}_{\mathrm{n}}=69.6 \mathrm{kPa} 101$ Figure 4.51: Direct shear test results for material A, B, and C-sand interface at $\mathrm{S}_{\mathrm{n}}=103.9 \mathrm{kPa}$

Figure 4.52: Pullout test results for material A-sand interface at $\mathrm{S}_{\mathrm{n}}=103.4 \mathrm{kPa} \ldots \ldots \ldots \ldots \ldots \ldots \ldots \ldots . . . . . . . .104$

Figure 4.53: Pullout test results for material A-sand interface at $\mathrm{S}_{\mathrm{n}}=69 \mathrm{kPa} \ldots \ldots \ldots \ldots \ldots \ldots \ldots \ldots \ldots . . . . . . . . . . . . .105$

Figure 4.54: Pullout test results for material A-sand interface at $\mathrm{S}_{\mathrm{n}}=103.4 \mathrm{kPa} \ldots \ldots \ldots \ldots \ldots \ldots \ldots . . . . . . . . .106$

Figure 4.55: Pullout failure envelope for material A - sand interface........................................ 107

Figure 4.56: Pullout test results for material B-sand interface at $\mathrm{S}_{\mathrm{n}}=34.5 \mathrm{kPa} \ldots \ldots \ldots \ldots \ldots \ldots \ldots \ldots . . . . . . . . . . .108$

Figure 4.57: Pullout test results for material B-sand interface at $\mathrm{S}_{\mathrm{n}}=69 \mathrm{kPa} \ldots \ldots \ldots \ldots \ldots \ldots \ldots \ldots \ldots . . . . . . . . . . . . . .109$

Figure 4.58: Pullout test results for material B-sand interface at $\mathrm{S}_{\mathrm{n}}=103.4 \mathrm{kPa} \ldots \ldots \ldots \ldots \ldots \ldots \ldots . . . . . . . . .110$

Figure 4.59: Pullout failure envelope for material B - sand interface. ...................................... 111

Figure 4.60: Pullout test results for material $\mathrm{C}$ - sand interface at $\mathrm{S}_{\mathrm{n}}=34.5 \mathrm{kPa} \ldots \ldots \ldots \ldots \ldots \ldots \ldots . . . . . . . . .112$

Figure 4.61: Pullout test results for material C - sand interface at $\mathrm{S}_{\mathrm{n}}=69 \mathrm{kPa} \ldots \ldots \ldots \ldots \ldots \ldots \ldots \ldots . . . . . . . . . . .113$

Figure 4.62: Pullout test results for material C - sand interface at $\sigma_{\mathrm{n}}=103.4 \mathrm{kPa} . \ldots \ldots \ldots \ldots \ldots \ldots . . . . . . . .114$

Figure 4.63: Pullout failure envelope for material C-sand interface. ........................................ 115

Figure 4.64: Pullout test results for material A - silt interface at $\mathrm{S}_{\mathrm{n}}=34.5 \mathrm{kPa}$ and $0 \%$ water content.

Figure 4.65: Pullout test results for material A - silt interface at $\mathrm{S}_{\mathrm{n}}=69 \mathrm{kPa}$ and $0 \%$ water content.

Figure 4.66: Pullout test results for material A - silt interface at $\mathrm{S}_{\mathrm{n}}=103.4 \mathrm{kPa}$ and $0 \%$ water content. 118

Figure 4.67: Pullout failure envelope for material A - silt interface at $0 \%$ water content. 119 
Figure 4.68: Pullout test results for material A - silt interface at $\mathrm{S}_{\mathrm{n}}=34.5 \mathrm{kPa}$ and $10 \%$ water content.

Figure 4.69: Pullout test results for material A - silt interface at $\mathrm{S}_{\mathrm{n}}=69 \mathrm{kPa}$ and $10 \%$ water content.

Figure 4.70: Pullout test results for material A - silt interface at $\mathrm{S}_{\mathrm{n}}=103.4 \mathrm{kPa}$ and $10 \%$ water content.

Figure 4.71: Pullout failure envelope for material A - silt interface at 10\% water content.

Figure 4.72: Pullout test results for material A - silt interface at $\mathrm{S}_{\mathrm{n}}=34.5 \mathrm{kPa}$ and $15 \%$ water content.

Figure 4.73: Pullout test results for material A - silt interface at $S_{n}=69 \mathrm{kPa}$ and $15 \%$ water content.

Figure 4.74: Pullout test results for material A - silt interface at $\mathrm{S}_{\mathrm{n}}=103.4 \mathrm{kPa}$ and $15 \%$ water content. 126

Figure 4.75: Pullout failure envelope for material A - silt interface at 15\% water content. 127

Figure 4.76: Pullout test results for material B - silt interface at $\mathrm{S}_{\mathrm{n}}=34.5 \mathrm{kPa}$ and $0 \%$ water content.

Figure 4.77: Pullout test results for material B - silt interface at $\mathrm{S}_{\mathrm{n}}=69 \mathrm{kPa}$ and $0 \%$ water content.

Figure 4.78: Pullout test results for material B - silt interface at $\mathrm{S}_{\mathrm{n}}=103.4 \mathrm{kPa}$ and $0 \%$ water content.

Figure 4.79: Pullout failure envelope for material B - silt interface at $0 \%$ water content.

Figure 4.80: Pullout test results for material B - silt interface at $\mathrm{S}_{\mathrm{n}}=34.5 \mathrm{kPa}$ and $10 \%$ water content.

Figure 4.81: Pullout test results for material B - silt interface at $\mathrm{S}_{\mathrm{n}}=69 \mathrm{kPa}$ and $10 \%$ water content.

Figure 4.82: Pullout test results for material B - silt interface at $\mathrm{S}_{\mathrm{n}}=103.4 \mathrm{kPa}$ and $10 \%$ water content.

Figure 4.83: Pullout failure envelope for material B - silt interface at 10\% water content........ 135

Figure 4.84: Pullout test results for material B - silt interface at $\mathrm{S}_{\mathrm{n}}=34.5 \mathrm{kPa}$ and $15 \%$ water content. 
Figure 4.85: Pullout test results for material B - silt interface at $\mathrm{S}_{\mathrm{n}}=69 \mathrm{kPa}$ and $15 \%$ water content.

Figure 4.86: Pullout test results for material B - silt interface at $\mathrm{S}_{\mathrm{n}}=103.4 \mathrm{kPa}$ and $15 \%$ water content. 138

Figure 4.87: Pullout failure envelope for material B - silt interface at 15\% water content 139

Figure 4.88: Pullout test results for material C - silt interface at $\mathrm{S}_{\mathrm{n}}=34.5 \mathrm{kPa}$ and $0 \%$ water content.

Figure 4.89: Pullout test results for material C - silt interface at $\mathrm{S}_{\mathrm{n}}=69 \mathrm{kPa}$ and $0 \%$ water content.

Figure 4.90: Pullout test results for material C - silt interface at $\mathrm{S}_{\mathrm{n}}=103.4 \mathrm{kPa}$ and $0 \%$ water content.

Figure 4.91: Pullout failure envelope for material C - silt interface at $0 \%$ water content.

Figure 4.92: Pullout test results for material C - silt interface at $\mathrm{S}_{\mathrm{n}}=34.5 \mathrm{kPa}$ and $10 \%$ water content.

Figure 4.93: Pullout test results for material C - silt interface at $S_{n}=69 \mathrm{kPa}$ and $10 \%$ water content.

Figure 4.94: Pullout test results for material C - silt interface at $\mathrm{S}_{\mathrm{n}}=103.4 \mathrm{kPa}$ and $10 \%$ water content.

Figure 4.95: Pullout failure envelope for material C - silt interface at 10\% water content........ 147

Figure 4.96: Pullout test results for material C - silt interface at $\mathrm{S}_{\mathrm{n}}=34.5 \mathrm{kPa}$ and $15 \%$ water content.

Figure 4.97: Pullout test results for material C - silt interface at $\mathrm{S}_{\mathrm{n}}=69 \mathrm{kPa}$ and $15 \%$ water content.

Figure 4.98: Pullout test results for material C - silt interface at $\mathrm{S}_{\mathrm{n}}=103.4 \mathrm{kPa}$ and $15 \%$ water content.

Figure 4.99: Pullout failure envelope for material C - silt interface at 15\% water content........ 151

Figure 4.100: Pullout test results for material B - clay interface at $\sigma_{\mathrm{n}}=34.5 \mathrm{kPa}$ and $0 \%$ water content.

Figure 4.101: Pullout test results for material B - clay interface at $\sigma_{\mathrm{n}}=69 \mathrm{kPa}$ and $0 \%$ water content.

Figure 4.102: Pullout test results for material B - clay interface at $\sigma_{\mathrm{n}}=103.4 \mathrm{kPa}$ and $0 \%$ water content. 
Figure 4.103: Pullout failure envelope for material B - clay at $0 \%$ water content.

Figure 4.104: Pullout test results for material B - clay interface at $\sigma_{\mathrm{n}}=34.5 \mathrm{kPa}$ and $10 \%$ water content. 156

Figure 4.105: Pullout test results for material B - clay interface at $\sigma_{\mathrm{n}}=69 \mathrm{kPa}$ and $10 \%$ water content.

Figure 4.106: Pullout test results for material B - clay interface at $\sigma_{\mathrm{n}}=103.4 \mathrm{kPa}$ and $10 \%$ water content. 158

Figure 4.107: Pullout failure envelope for material B - clay interface at 10\% water content. ... 159 Figure 4.108: Pullout test results for material B - clay interface at $\sigma_{\mathrm{n}}=34.5 \mathrm{kPa}$ and $15 \%$ water content.

Figure 4.109: Pullout test results for material B - clay interface at $\sigma_{\mathrm{n}}=69 \mathrm{kPa}$ and $15 \%$ water content.

Figure 4.110: Pullout test results for material B - clay interface at $\sigma_{\mathrm{n}}=103.4 \mathrm{kPa}$ and $15 \%$ water content.

Figure 4.111: Pullout failure envelope for material B - clay interface at 15\% water content.... 163

Figure 4.112: Pullout test results for material A-sand interface at $34.5 \mathrm{kPa}$. 165

Figure 4.113: Pullout test results for material A-sand and silt interface at $\mathrm{S}_{\mathrm{n}}=34.5 \mathrm{kPa}$ and $0 \%$ water content. 166

Figure 4.114: Pullout test results for material A-sand and silt interface at $\mathrm{S}_{\mathrm{n}}=69 \mathrm{kPa}$ and $0 \%$ water content. 167

Figure 4.115: Pullout test results for material A-sand and silt interface at $\mathrm{S}_{\mathrm{n}}=103.4 \mathrm{kPa}$ and $0 \%$ water content.

Figure 4.116: Pullout test results for material C-sand and silt interface at $\mathrm{S}_{\mathrm{n}}=34.5 \mathrm{kPa}$ and $0 \%$ water content.

Figure 4.117: Pullout test results for material C-sand and silt interface at $\mathrm{S}_{\mathrm{n}}=69 \mathrm{kPa}$ and $0 \%$ water content. 170

Figure 4.118: Pullout test results for material C-sand and silt interface at $\mathrm{S}_{\mathrm{n}}=103.4 \mathrm{kPa}$ and $0 \%$ water content.

Figure 4.119: Pullout test results for material B-silt and clay interface at $\mathrm{S}_{\mathrm{n}}=34.5 \mathrm{kPa}$ and $10 \%$ water content.

Figure 4.120: Pullout test results for material B-silt and clay interface at $\mathrm{S}_{\mathrm{n}}=69 \mathrm{kPa}$ and $10 \%$ water content. 
Figure 4.121: Pullout test results for material B-silt and clay interface at $\mathrm{S}_{\mathrm{n}}=103.4 \mathrm{kPa}$ and $10 \%$ water content.

Figure 4.122: Pullout test results for material B-silt and clay interface at $\mathrm{S}_{\mathrm{n}}=34.5 \mathrm{kPa}$ and $15 \%$ water content.

Figure 4.123: Pullout test results for material B-silt and clay interface at $\mathbf{S}_{\mathrm{n}}=69 \mathrm{kPa}$ and $15 \%$ water content. 176

Figure 4.124: Pullout test results for material B-silt and clay interface at $\mathrm{S}_{\mathrm{n}}=103.4 \mathrm{kPa}$ and $15 \%$ water content.

Figure 4.125: Pullout test results for material B-sand, silt and clay interfaces at $0 \%$ water content and $\mathrm{S}_{\mathrm{n}}=34.5 \mathrm{kPa}$. 178

Figure 4.126: Pullout test results for material B-sand, silt, and clay interfaces at $0 \%$ water content and $\mathrm{s}_{\mathrm{n}}=69 \mathrm{kPa}$.

Figure 4.127: Pullout test results for material B-sand, silt, and clay interfaces at $0 \%$ water content and $\mathrm{S}_{\mathrm{n}}=103.4 \mathrm{kPa}$. 180

Figure 4.128: Pullout test results for geosynthetic-sand interfaces at $\mathrm{S}_{\mathrm{n}}=34.5 \mathrm{kPa}$. 181

Figure 4.129: Pullout test results for geosynthetic-sand interfaces at $S_{n}=69 \mathrm{kPa}$. 182

Figure 4.130: Pullout test results for geosynthetic-sand interface at $\mathrm{S}_{\mathrm{n}}=103.4 \mathrm{kPa}$. 183

Figure 4.131: Pullout results for materials A, B, and C, $\mathrm{S}_{\mathrm{n}}=34.5 \mathrm{kPa}$, silt $0 \%$ water content. 184

Figure 4.132: Pullout test results for materials A, B, and C-silt interfaces at $\mathrm{S}_{\mathrm{n}}=34.5 \mathrm{kPa}$ and silt $10 \%$ water content. 185

Figure 4.133: Pullout test results for materials A, B, and C-silt interfaces at $\mathrm{S}_{\mathrm{n}}=34.5 \mathrm{kPa}$ and silt $15 \%$ water content. 186

Figure 4.134: Pullout test results for materials A, B, and C-silt interfaces at $\mathrm{S}_{\mathrm{n}}=69 \mathrm{kPa}$ and silt $0 \%$ water content. 187

Figure 4.135: Pullout test results for materials A, B, and C-silt interfaces at $\mathbf{S}_{\mathrm{n}}=69 \mathrm{kPa}$ and silt $10 \%$ water content. 188

Figure 4.136: Pullout test results for materials A, B, and C-silt interfaces at $\mathrm{S}_{\mathrm{n}}=69 \mathrm{kPa}$ and silt $15 \%$ water content. 189

Figure 4.137: Pullout test results for materials A, B, and C-silt interfaces at $\mathbf{S}_{\mathrm{n}}=103.4 \mathrm{kPa}$ and silt $0 \%$ water content. 
Figure 4.138: Pullout test results for materials A, B, and C-silt interfaces at $\mathrm{S}_{\mathrm{n}}=103.4 \mathrm{kPa}$ and silt $10 \%$ water content.

Figure 4.139: Pullout test results for materials A, B, and C-silt interfaces at $\mathrm{S}_{\mathrm{n}}=103.4 \mathrm{kPa}$ and silt $15 \%$ water content. 192

Figure 4.140: Pullout test results for material A-silt interface at 0, 10, and 15\% water contents and $\mathrm{S}_{\mathrm{n}}=34.5 \mathrm{kPa}$.

Figure 4.141: Pullout test results for material A-silt interface at 0, 10, and 15\% water contents and $\mathrm{S}_{\mathrm{n}}=69 \mathrm{kPa}$. 194

Figure 4.142: Pullout test results for material A-silt interface at 0, 10, and 15\% water contents and $\mathrm{S}_{\mathrm{n}}=103.4 \mathrm{kPa}$. 195

Figure 4.143: Pullout test results for material B-silt interface at $\mathrm{S}_{\mathrm{n}}=34.5 \mathrm{kPa}$ with 0,10 and $15 \%$ water contents. 196

Figure 4.144: Pullout test results for material B-silt interface at $\mathrm{S}_{\mathrm{n}}=69 \mathrm{kPa}$ with 0, 10 and 15\% water contents.

Figure 4.145: Pullout test results for material B-silt interface at $\mathrm{S}_{\mathrm{n}}=103.4 \mathrm{kPa}$ with 0,10 and $15 \%$ water contents.

Figure 4.146: Pullout test results for material C-silt interface at $S_{n}=34.5 \mathrm{kPa}$ with 0,10 and $15 \%$ water contents.

Figure 4.147: Pullout test results for material C-silt interface at $\mathrm{S}_{\mathrm{n}}=69 \mathrm{kPa}$ with 0,10 and 15\% water contents.

Figure 4.148: Pullout test results for material C-silt interface at $\mathrm{S}_{\mathrm{n}}=103.4 \mathrm{kPa}$ with 0,10 and $15 \%$ water contents

Figure 4.149: Pullout test results for material B-clay interface at $S_{n}=35.4 \mathrm{kPa}$ and 0,10 and $15 \%$ water contents.

Figure 4.150: Pullout test results for material B-clay interface at $\mathrm{S}_{\mathrm{n}}=69 \mathrm{kPa}$ and 0, 10 and 15\% water contents. 203

Figure 4.151: Pullout test results for material B-clay interface at $\mathrm{S}_{\mathrm{n}}=103.4 \mathrm{kPa}$ and 0,10 and $15 \%$ water contents.

Figure 4.152: Pullout and direct shear test results for geosynthetic-sand interfaces at $\mathrm{S}_{\mathrm{n}}=34.9$

$\mathrm{kPa}$. 
Figure 4.153: Pullout and direct shear test results geosynthetic-sand interfaces at $\mathbf{S}_{\mathrm{n}}=69.3 \mathrm{kPa}$.

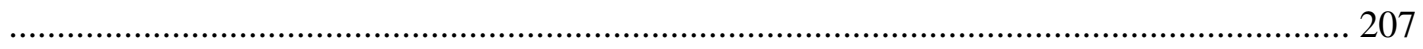

Figure 4.154: Pullout and direct shear results for geosynthetic-sand interfaces at $\mathrm{S}_{\mathrm{n}}=103.7 \mathrm{kPa}$. 208

Figure 4.155: Pullout and direct shear test results for material A -sand interface with 0\% water content.

Figure 4.156: Pullout and direct shear test results for material B-sand interface with $0 \%$ water content. 210

Figure 4.157: Pullout and direct shear test results for material C -sand interface with $0 \%$ water content. 


\section{CHAPTER 1: INTRODUCTION}

\subsection{Background}

Due to low mass density (mass per unit area) and high strength properties, geosynthetics have many advantages over other soil reinforcing techniques [Madhav et al., 1998]. Geosynthetic materials have been used in a number of geotechnical applications including soil reinforcements since early 1980's in North America and several other countries in the world. Significant amounts of work on geosyntheticreinforced soil retaining structures have been done in Japan since early 1980s [Tatsuoka and Leshchinsky, 1994]. A number of case histories on the use of geosynthetics for reinforcing soil retaining walls are described in the literature [Miki et. al, 1994; Tateyama et. al, 1994; Hori et. al, 1994; Tatsuoka and Leshchinsky, 1994].

A literature review was performed to gain knowledge of recent work that has been done in the area of soil-geosynthetic interface properties. Two specific testing methods were considered: the direct shear test and geosynthetic pullout test. Though these are the two primary methods of interest, other methods can also be considered to obtain a more general understanding of the material and its uses. Several papers were reviewed; a group that was of most interest is included in this report.

Two tests commonly used to evaluate soil-geosynthetic interface properties are the direct shear test and the pullout test. These are the tests that are used in the present study. Because direct shear and pullout testing devices yield similar characteristics, a two-phase program consisting of these tests has been used [Cazzuffi et al., 1993; Bauer and Zhao, 1993]. This enables a complete investigation of the soils and geosynthetics that are being used. Exploring the influence of the orientation of the synthetic and shear plane as well as soil dilatancy effects is very important especially for reinforced embankments and retaining walls [Bauer and Zhao, 1993]. However, interface plane orientation is not explored in the present study. 


\subsection{Direct Shear Testing Programs}

Direct shear testing has been used to study soil-geosynthetic properties [Cazzuffi et al., 1993; Dove and Frost, 1999; Bauer and Zhao, 1993; Moss and Anderson, 2000; Moss, 1999; and Matsuoka et al, 2001]. The purpose of direct shear testing is to find interface properties. The interfaces in the present study are made up of soil and geosynthetic materials. The properties that are found from direct shear testing consist of the angle of friction and cohesion between the soil-soil, soil-geosynthetic, and geosynthetic-geosynthetic interfaces. Some possible influences can be explored outside of the interface. Examples of these influences are boundary conditions, soil density, and reinforcement characteristics, such as tensile strength. Previous research work that has been done in this area is discussed in this section.

When determining failure values of interface shear stress a stress-strain curve is used. In the present study the peak shear stress value was used to determine failure. However, the residual shear stress value can also be used. The residual shear stress value is reached when the shear resistance remains constant. It is usually reported as the last shear stress value recorded during a test [Moss, 1999].

When a dense granular soil reinforced with geogrid is sheared the soil particles dilate and cause tensile strains in the geogrid [Bauer and Zhao, 1993]. These strains are proportional to the amount of dilation that occurs. The shear resistance of the system is a direct result of the orientation of geogrid with respect to the shear plane. The highest resistance was found when the shear box orientation was at an angle of 60 degrees [Bauer and Zhao, 1993]. However, the goal of our study is to investigate soil-geosynthetic interface properties, not to explore the orientation effects of the interface plane.

The direct shear box can vary in size. An apparatus with contact area of $0.1 \mathrm{~m}^{2}$ was developed for direct shear and pullout testing [Cazzuffi et al., 1993]. An electronic testing machine on both uniaxial and biaxial oriented geogrids applied vertical and horizontal loads. A large box was built with dimensions $1000 \times 1000 \times 940$ mm for direct shear testing which could perform tests from zero to ninety degrees inclination of the interface plane [Bauer and Zhao, 1993]. Constant displacement rates ranging from 0.1 to $5 \mathrm{~mm} / \mathrm{min}$ are generally used for direct shear tests. However, based on experimental data, soil-geosynthetic interaction was not influenced by the rate of 
displacement [Cazzuffi et al., 1993]. The displacement rate in the current study is 2 $\mathrm{mm} / \mathrm{min}$.

Different soils have been used in the past to identify interface properties using direct shear testing [Cazzuffi et al., 1993; Bauer and Zhao, 1993]. A silty sand and gravel were used for direct shear testing [Cazzuffi et al., 1993]. A poorly graded coarse sand with modified proctor test density of $19.8 \mathrm{kN} / \mathrm{m}^{3}$ and optimum moisture content of 11 percent was used in addition to a well-graded crushed limestone aggregate [Bauer and Zhao, 1993]. The limestone had a modified proctor test dry density of $22 \mathrm{kN} / \mathrm{m}^{3}$ and optimum moisture content of 6.8 percent. A natural sand was used in the present study with properties found in chapter two. A polyester mesh and a uniaxial polyethylene grid geosynthetic were used. For direct shear testing natural sand was used in the present study (see Figure 3.1) along with geosynthetics with properties found in Table 3.1.

Compaction was done in different layers to achieve the desired soil density in all of the laboratory experiments [Bauer and Zhao, 1993]. In all situations the soil was placed into the box in layers approximately $150 \mathrm{~mm}$ thick, then manually leveled and compacted with an electric impact hammer until the soil reached the top of the box. The reinforcement was placed once the soil had reached the appropriate level and then folded in a way to prevent separation during the test. Moisture and density are typically known and sometimes checked with a nuclear gauge. In the present study soil and geosynthetics were placed in a similar manner. This is discussed further in chapter two.

Data obtained from geogrid-soil interfaces were very similar to those of soil-soil interfaces. The angle of friction decreased as the normal pressure increased [Cazzuffi et al., 1993]. This behavior is explored with direct shear and pullout testing in the present study.

New developments in direct shear testing have recently been introduced. The first is a new in-situ direct shear test. This test is run in the field by simply pulling an imbedded latticed shearing frame horizontally with ropes or chains [Matsuoka et al, 2001]. The simplicity and accuracy makes this process very desirable. Large versions of this test can be run on more granular soils like rockfills and a smaller version can be used for sand and clay. Another new development in direct shear testing is the cylindrical direct shear test. This test is designed around the present $0.3 \mathrm{~m}$ (12 in) direct shear 
apparatus [Moss and Anderson, 2000]. There are two main differences between the cylindrical direct shear test and the standard direct shear test. The cylindrical direct shear test allows a constant contact area to be used throughout the entire test. This is advantageous because many geosynthetic interfaces loose strength as the contact area decreases. The other difference is the ability to measure unlimited displacements, which the standard direct shear test cannot do. A pressure chamber is mounted to the device and is used to apply a constant normal pressure throughout the test. Geosyntheticgeosynthetic interface properties have been successfully measured with this method and the process of measuring soil-geosynthetic interfaces is under evaluation [Moss and Anderson, 2000]. The type of direct shear test used in the present study is a standard direct shear test.

\subsection{Pullout Testing Programs}

Direct shear testing has been used to study soil-geosynthetic properties [Farrag and Griffin, 1993; Cazzuffi et al., 1993; Raju and Fannin, 1997; Collin and Berg, 1993; Gurung, 2000; Yuan et al., 2003; Alobaidi et al., 1997; Allen et al., 1992; Lopes and Ladeira, 1996; and Razaqpur et al., 1993]. In the present study pullout tests are used to measure the properties of soil-geosynthetic interfaces. There are two main interface characteristics determined from pullout tests. These are the angle of friction and the cohesion. There are also other factors we will explore that may influence the test results. These factors include boundary conditions, moisture content, soil characteristics and reinforcement characteristics.

Many different pullout device setups have been used in the past. This illustrates the need for a standard pullout procedure to be developed in order to have consistent and comparable results among researchers [Farrag and Griffin, 1993].

Classically there are two methods of pullout testing: those tests that are controlled by displacement and those controlled by loading. The load-controlled method can be used to apply loading cycles or a constant load can be applied throughout the entire test to measure creep characteristics. Tests that are performed with a constant

displacement rate are called displacement-controlled tests. Very similar results were 
produced between the constant displacement rate and cyclic loading methods [Raju and Fannin, 1997]. The present study is based on a constant displacement method. The displacement rate is approximately equal to $6 \mathrm{~mm} / \mathrm{min}$ for all specimens.

Several parameters were evaluated at the Geosynthetic Engineering Research Laboratory in Louisiana [Farrag and Griffin, 1993]. These parameters include: effects of boundary conditions, moisture content, and soil confinement. A constant confining pressure $48.2 \mathrm{kN} / \mathrm{m}^{2}$ (7 psi) and displacement rate of $1.5 \mathrm{~mm} / \mathrm{min}$ (0.06 in/min) were used for each specimen except when testing the effects of boundary conditions, where a pressure of $48 \mathrm{kN} / \mathrm{m}^{2}$ and a displacement rate of $4 \mathrm{~mm} / \mathrm{min}$ were used. These testing parameters are similar to those in the present study. In the present study a constant displacement rate of approximately $6 \mathrm{~mm} / \mathrm{min}$ was used along with confining pressures of $34.5 \mathrm{kPa}$ (5 psi), $69 \mathrm{kPa}$ (10 psi), and $103.4 \mathrm{kPa}$ (15 psi).

A two-phase program was used to examine the relationship of soil-geosynthetic and geosynthetic-geosynthetic interfaces [Cazzuffi et al., 1993]. Phase one consisted of direct shear and pullout testing and phase two consisted of triaxial tests. Constant displacement rates of 0.1 and $0.5 \mathrm{~mm} / \mathrm{min}$ were used. The rate of displacement was found to play a negligible role in the results. Also found was that the residual shear resistance is almost half of the peak resistance.

Pullout resistance of geogrids under two different conditions was evaluated [Collin and Berg, 1993]. The first was a short-term, constant displacement test at a pullout rate of $1 \mathrm{~mm} / \mathrm{min}$. The second was a long-term (approximately 1000 hours) sustained load pullout test. Once the 1000-hour mark was reached in the long-term test method, the sample was displaced at a constant rate of $1 \mathrm{~mm} / \mathrm{min}$. Due to limitations and the scope of their study no differences were found between the long-term and short-term pullout test results. However, enough data was analyzed to conclude that this type of testing should be further evaluated in the future with more testing variables, such as confining pressure, soil type, and geogrid type.

Anchors embedded in reinforced soil have not been investigated fully. However, anchors embedded in unreinforced soil have been investigated in the past [Gurung, 2000]. A theoretical model was developed that helped in the assessment of anchors embedded in 
unreinforced soil. The predictions of the model, when compared to published results of soil-reinforcement pullout tests, were satisfactory.

Two important factors when analyzing a reinforced soil-geosynthetic system is the coefficient of interaction $\left(\mathrm{C}_{\mathrm{i}}\right)$ and the efficiency factor $\left(f_{\mathrm{ds}}\right)$. The coefficient of interaction allows the peak interface shear strength from the pullout tests to be compared with the residual internal shear strength of the soil [Yuan et al, 2003]. The coefficient of interaction $\left(C_{i}\right)$ is defined as [Yuan et al, 2003]:

$$
C_{i}=\frac{F}{2(A)\left(\sigma_{n} \tan \phi+c\right)}
$$

$$
\text { where: } \quad \begin{array}{ll}
F & =\text { maximum pullout load }(\mathrm{kN}) \\
2 & =\text { considers both surfaces of specimen in contact with soil } \\
A & =\text { initial embedded area of specimen }\left(\mathrm{m}^{2}\right) \\
\sigma_{n} & =\text { total normal stress applied to the geogrid specimen }(\mathrm{kPa}) \\
\phi & =\text { residual friction angle of the soil being used in testing (degrees) } \\
c & =\text { residual cohesion of the soil being used in testing }(\mathrm{kPa})
\end{array}
$$

The efficiency factor, which is sometimes called the friction ratio, allows the soil-soil interface angle of friction to be compared to the soil-geosynthetic interface angle of friction. The efficiency factor is defined as [Cazzuffi et al, 1991]:

$$
f_{d s}=\frac{\tan \phi_{s g}}{\tan \phi_{s s}}
$$

where: $\quad F_{\mathrm{sg}} \quad=$ friction angle of the soil-geosynthetic interface (degrees)

$$
F_{\mathrm{ss}} \quad=\text { friction angle of the soil (degrees) }
$$


Load transfer mechanisms for pullout tests have also been evaluated in the past [Alobaidi et al., 1997]. In order to determine the relationship between shear stress and horizontal displacement (at the soil-geosynthetic interface) a strain-softening model was used. After a small displacement in the specimen the peak pullout force was reached in the free-end of the geotextile (the embedded end without direct loading applied to it) except when breakage occurred. Also found was that when using an average interface friction angle the pullout resistance was overestimated.

At a large intersection in Seattle, Washington six large geosynthetic-reinforced soil retaining walls were constructed [Allen et al., 1992]. The purpose was to retain preload fills for bridge abutments temporarily. One of the walls with a height of $12.6 \mathrm{~m}$ was investigated. This wall supported a $5.3 \mathrm{~m}$ surcharge of fill above the top of the wall. Internal stresses and stains were measured by instrumentation that was installed at the site in the $12.6 \mathrm{~m}$ high wall. It was concluded that the overall strains and creep behavior was lower than expected and therefore existing design criteria is conservative [Allen et al., 1992].

Inextensible and extensible reinforcements have been tested and are able to be analyzed [Gurung and Iwao, 1998]. However, all of the reinforcements used in our study are extensible.

It has been found that a sleeve placed on the inner front wall of the pullout box will reduce the lateral earth pressure on the front wall and is commonly used in laboratory geosynthetic pullout testing [Lopes and Ladeira, 1996; Farrag and Griffin, 1993]. An increase in maximum pullout force of $10 \%$ and an increase in average vertical stress can occur in the absence of the front wall sleeve [Lopes and Ladeira, 1996]. In the testing device developed in the present study, a sleeve is included on the inner front wall of the pullout box to eliminate these influencing factors (see Figure 1.1). 


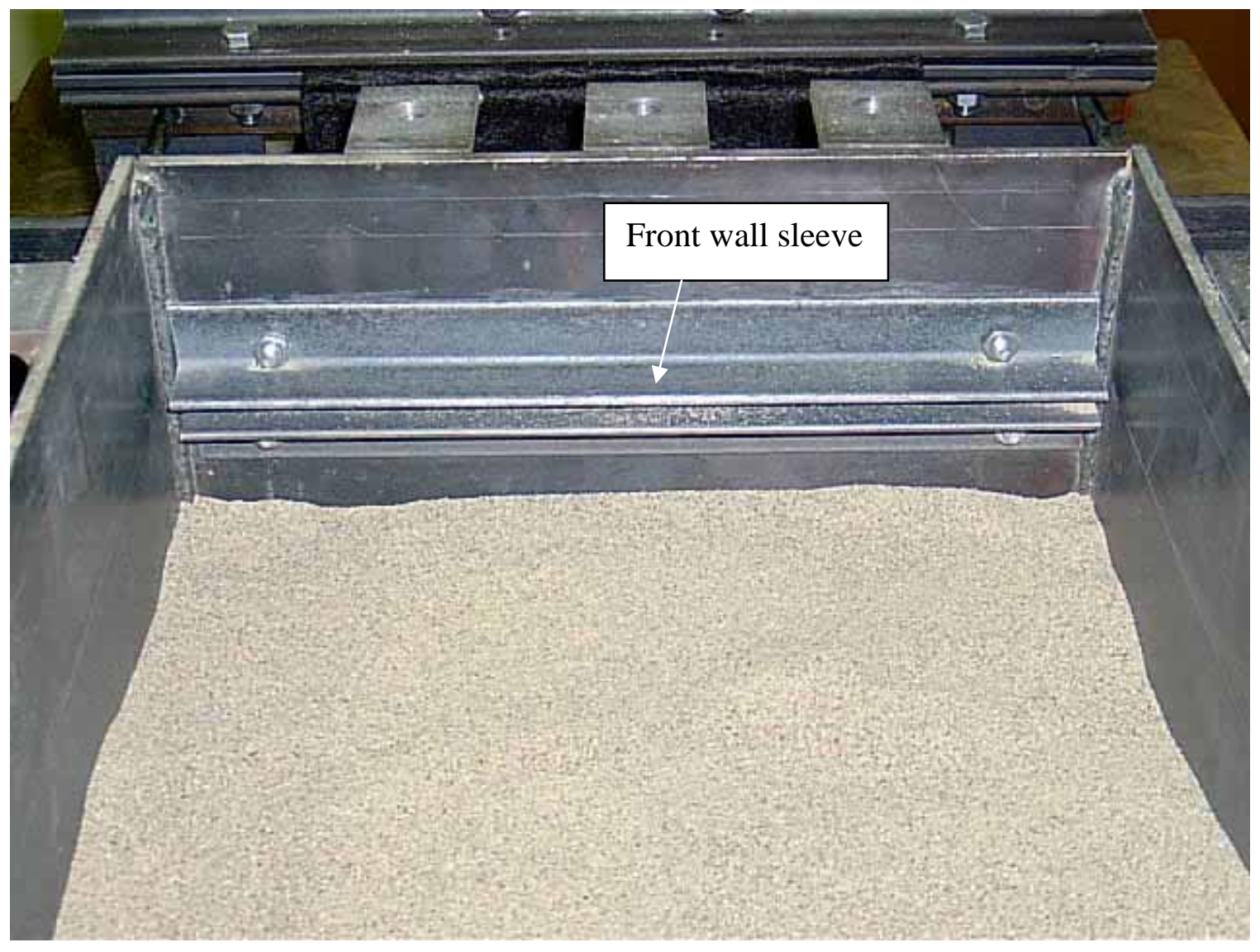

Figure 1.1: Picture of Pullout box front wall sleeve. 
A procedure for placement of the soil in the pullout box is important. The geotechnical properties of the soil are typically known. Characteristics such as density and moisture content are important because they can effect the interaction of the soil and geosynthetic. The soil should be placed in several leveled and compacted layers and this procedure should be carried out for all tests [Cazzuffi et al., 1993]. This is consistently done in the present study.

Placement and care for geosynthetics are important issues that may sometimes be overlooked. Geosynthetics that are mechanically damaged can significantly reduce pullout resistance [Razaqpur et al., 1993]. Friction between the sidewall and geosynthetic may reduce the normal pressure on the specimen. A distance of $15 \mathrm{~cm}$ (6 in) between the specimen and box sidewall was found to be the minimum distance needed to reduce this effect [Farrag and Griffin, 1993]. However, Lopes and Ladeira (1996) found that specimen width had very little effect on the pullout response, though there was a tendency of interface shear increase as the specimen width was reduced [Lopes and Ladeira, 1996].

The normal loading system for pullout testing can be done in different ways. One way is by using a jacking device [Farrag, K. and Griffin, P., 1993; and Lopes and Ladeira, 1996]. This is done by attaching the jack or jacks to the top of the pullout box lid. Using the jacks to apply a downward force can create a normal loading pressure on the reinforced soil system. Another method for applying normal pressure is by using pressurized airbags [Elias et al, 1998; and Collin and Berg, 1993]. This is the method that is used in the present study. However, unlike the study that was just mentioned our device contains two airbags. Both airbags are placed inside the pullout box. One is positioned on top of the reinforced soil and one on the bottom of the reinforced soil. This creates a more realistic in-situ condition.

\subsection{Applications of Geosynthetics in Transportation Infrastructure}

Geosynthetics are used in many applications and transportation infrastructure is one of them. Geotextiles, which were originally called filter clothes, emerged in the late fifties. They were used primarily by the transportation industry as a filtering agent in 
place of traditional graded aggregates [Ingold, 1994]. The interface properties found in the present study can be used in determining the proper use of geosynthetics in transportation infrastructure.

Recently geosynthetics have been used in roadways for added stability and drainage, which can increase the life of the roadway. Typically flexible pavements are used in these applications; however, geosynthetics are also used in unpaved roads. They can be used to separate layers. They can also be used to increase bearing capacity of the roadway [Tingle and Webster, 2003]. It was found that geosynthetics can prevent subgrade particles from moving into the base course layer, which can decrease the amount of rutting on a road [Al-Qadi and Appea, 2003]. In flexible pavements geosynthetics can improve the strength considerably in the elasto-plastic range. However, in the elastic range geosynthetics did not provide much improvement from traditional methods [Wathugala et al., 1996].

Reflective cracking is a major problem where geosynthetics can be useful. Geogrid reinforcements have been shown to delay the appearance of reflective cracking in overlayed roads [Kuo and Hsu, 2003]. A Reinforcing Factor, $R$, can be used to assess the reinforcing benefits of reducing the amount of reflective cracking [Cleveland et al., 2003].

Geosynthetics are known to be very useful when improving drainage conditions for pavements. It was found that fly ash is well suited for use with many geotextiles, and even under high hydraulic gradients no clogging was observed [Kutay and Aydilek, 2003]. However, long term performance should be further investigated.

Geosynthetics are also used to reinforce bridge abutments. Several parameters can control the effect of such a system. These parameters include: geometry, material properties and construction sequence. It was found that the modulus of the geogrid is the most significant of these parameters [Ashmawy et al., 2003]. The modulus of the Geogrid controlled strains within the geogrid layers and influenced wall deformation and settlement at the surface. 


\section{CHAPTER 2: EXPERIMENTAL APPARATUS}

\subsection{Design of Pullout Boxes}

Two pullout devices were built for this study. One contained pullout box A and the other contained pullout box B. Pullout box A was built before pullout box B. Box A is 6" $(15.2 \mathrm{~cm})$ deep, $12^{\prime \prime}(30.5 \mathrm{~cm})$ wide, and 18" $(45.7 \mathrm{~cm})$ long. In order to test the strength of this box it was pressurized to 70 psi in the laboratory. This pressure is far beyond the limit that would be applied during normal testing. The test was successful therefore experimentation was initiated.

The pullout boxes were used to study soil-geosynthetic interface properties. Various soil types and geosynthetics were used to create different interfaces. Details of these properties are discussed in chapter three. Effects of different soil and geosynthetic properties on these interfaces were explored. The basic design of these pullout boxes is shown in Figure 2.1.

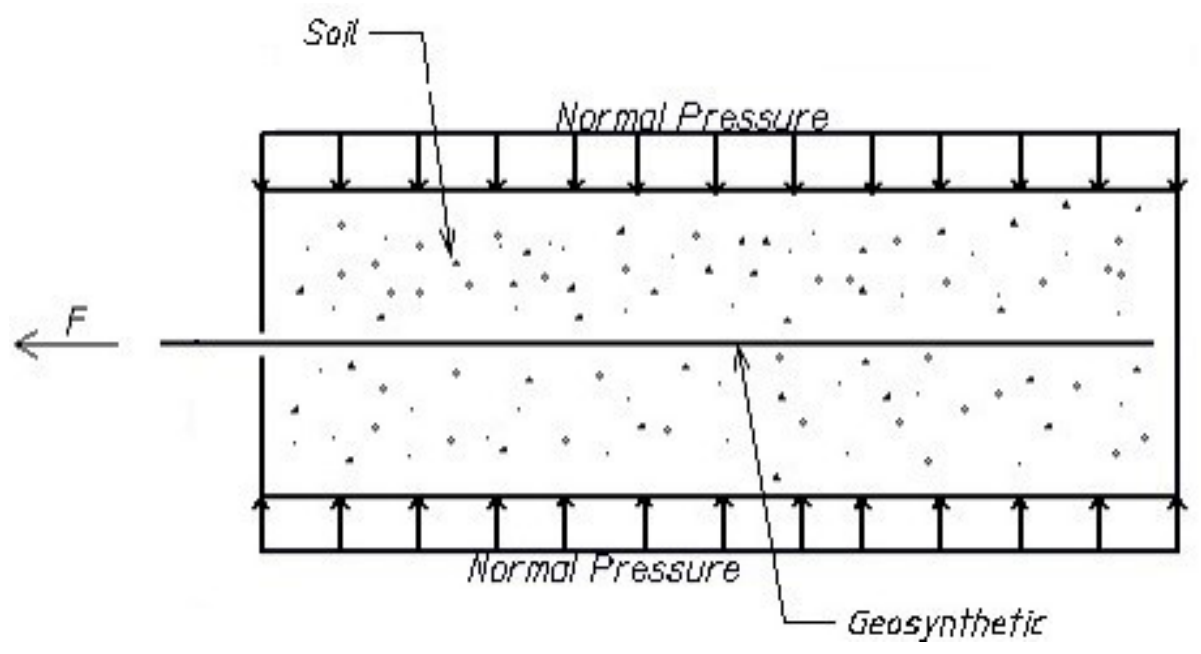

Figure 2.1: Schematic of pullout box design. 
The larger pullout box (pullout box B), which was designed for testing in this study, was modeled after pullout box A. Pullout box B was 6" (15.2 m) deep, 18" (45.7 m) wide, and 48" (122 cm) long. Having two pullout boxes of different sizes would allow the test results of the larger pullout box to be compared with the test results of the smaller pullout box and the effects of boundary conditions and specimen size to be studied. Analysis of the performance of pullout box B was done using Finite Element computer modeling software. The deflections in this model for pullout box B were compared with the deflections of the model for the existing pullout box A. In these models the normal pressure used was 200 psi, which was far more pressure than what was used in actual testing. After trying several ideas a final plan was developed. Figures 2.2 through 2.7 show some typical models taken from this process.

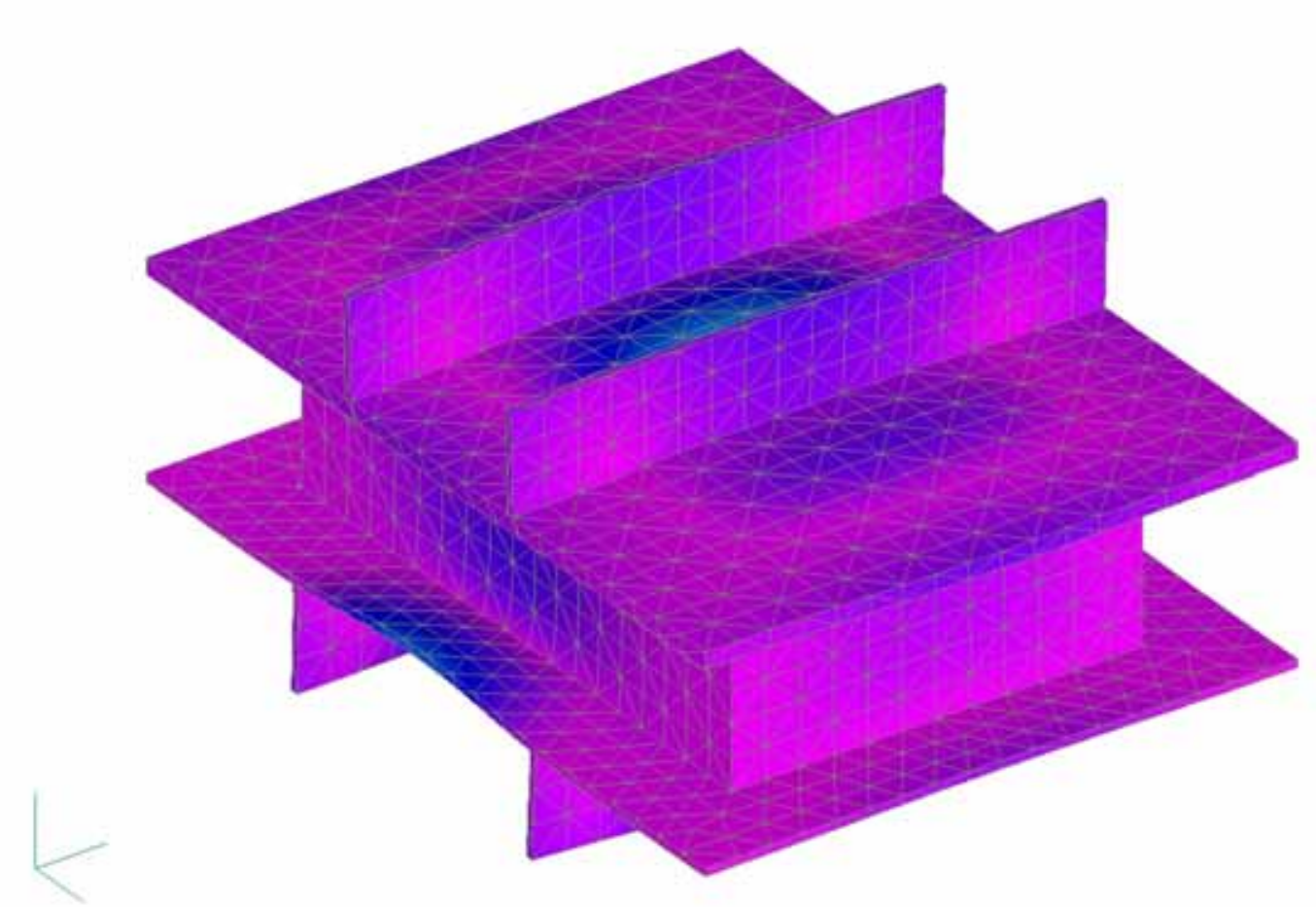

Figure 2.2: Dimetric view of displacement Finite Element model for pullout box A. 


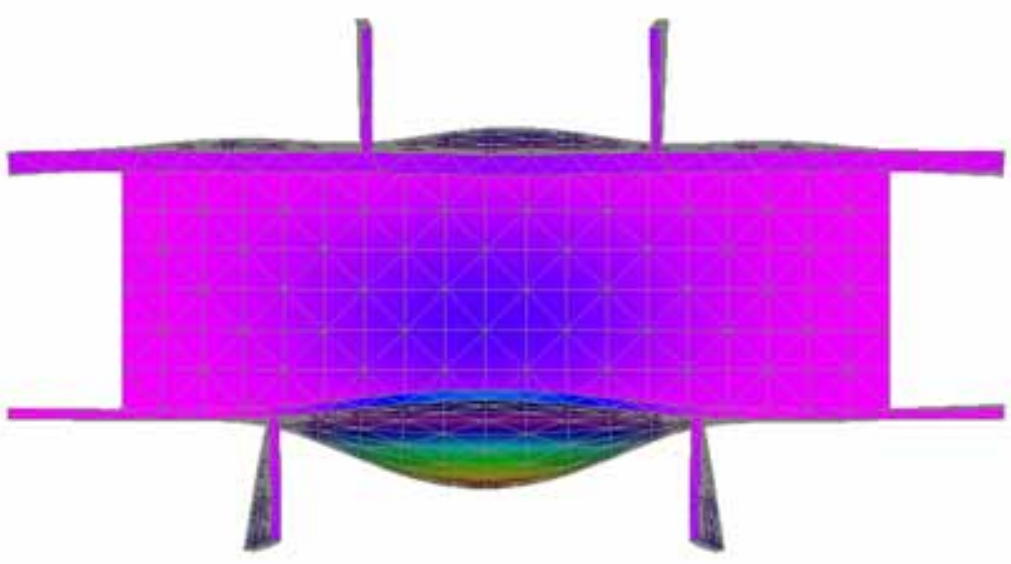

Den

Figure 2.3: Profile view of displacement Finite Element model for pullout box A. 


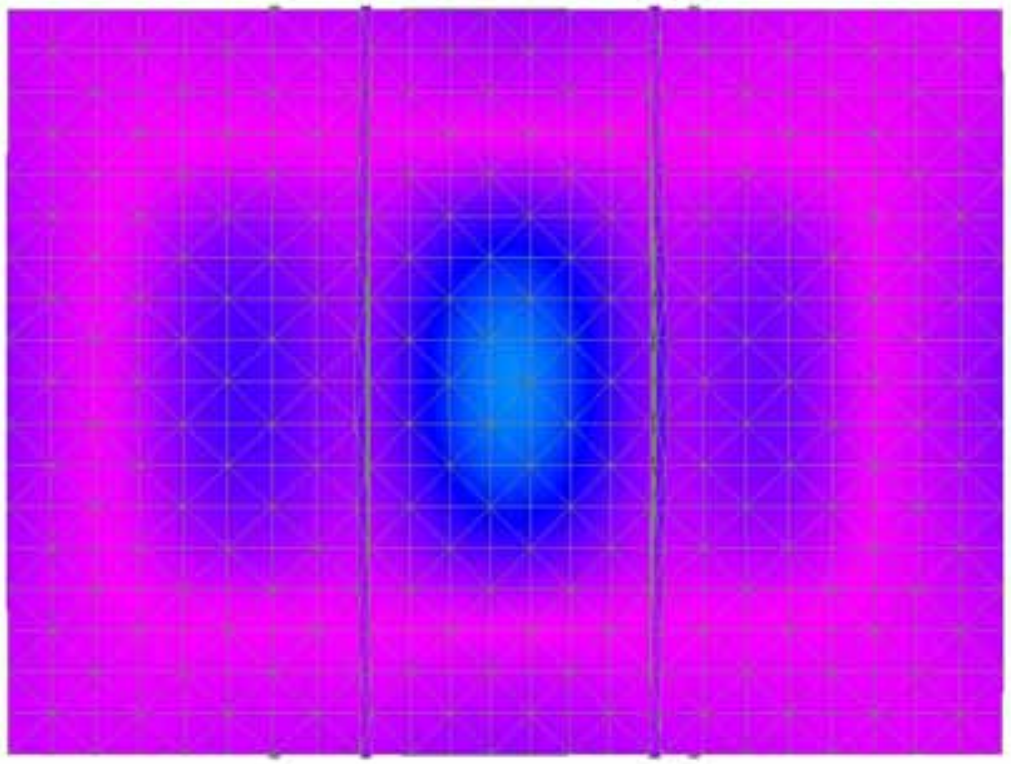

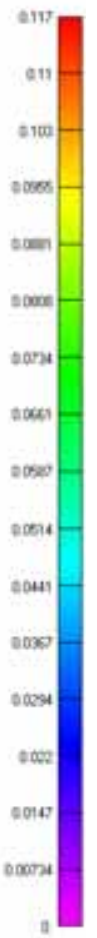

Figure 2.4: Plan view of displacement Finite Element model for pullout box A. 


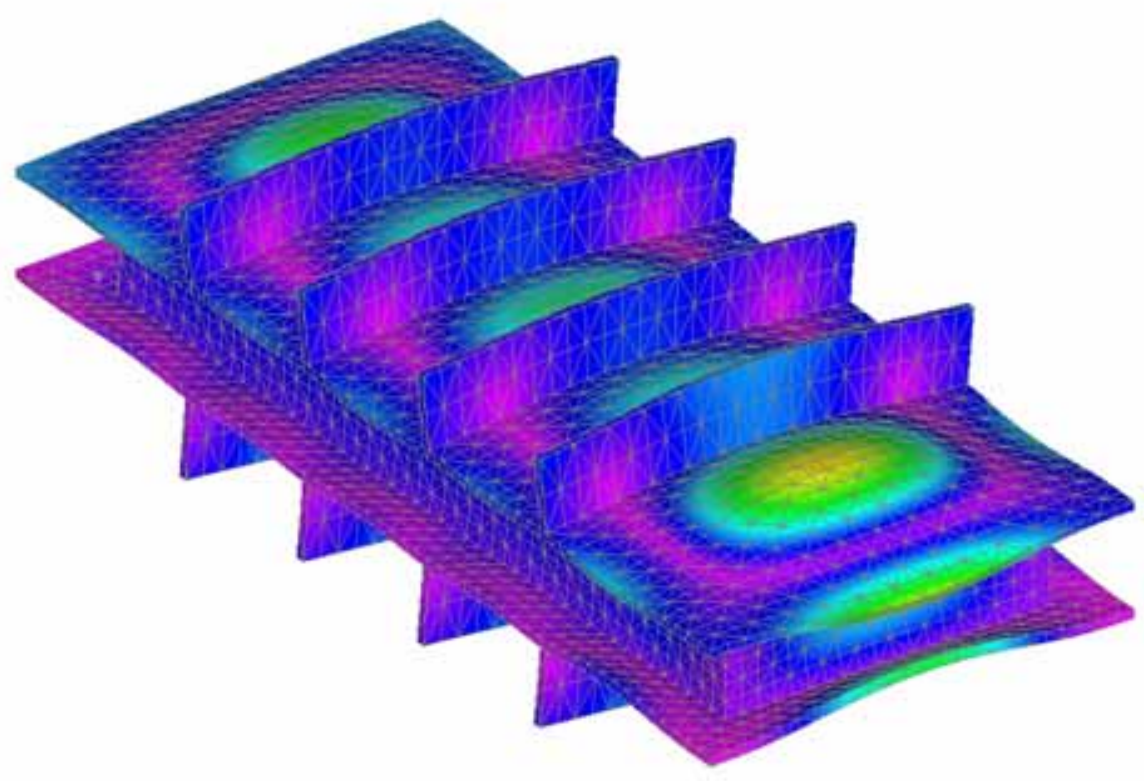

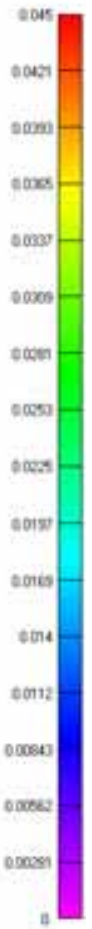

Figure 2.5: Dimetric view of displacement Finite Element model for box B. 


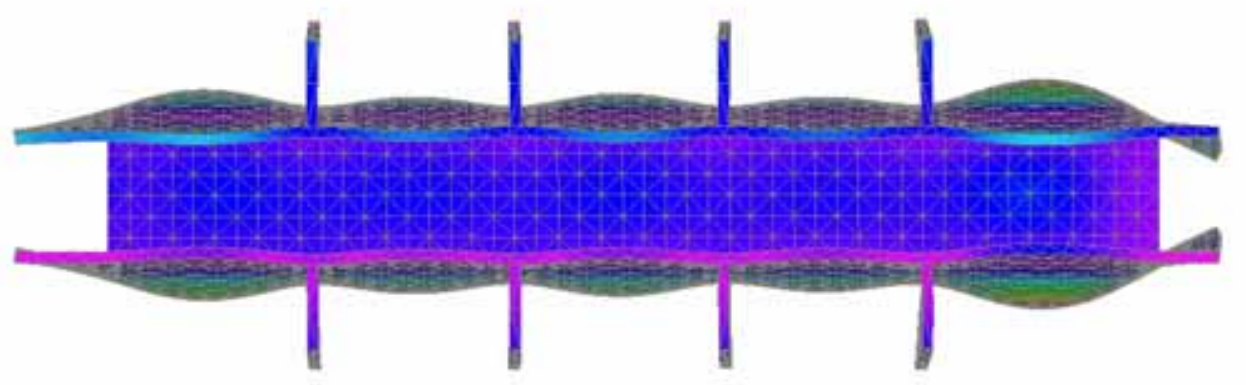

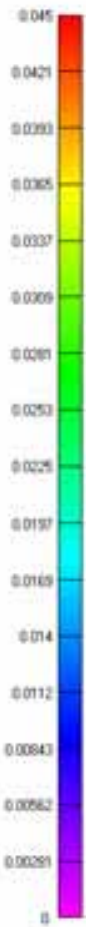

Figure 2.6: Profile view of displacement Finite Element model for box B. 


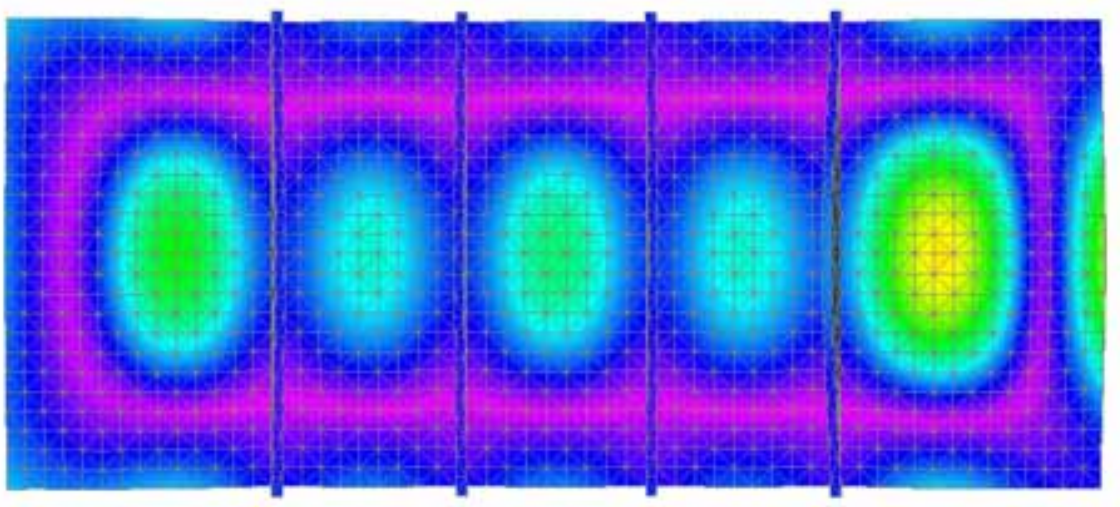

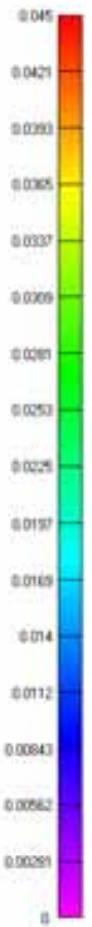

Figure 2.7: Plan view of Finite Element model showing displacement for box B. 


\subsection{Equipment used for Pullout Testing}

The major components for the pullout test device with box A are described below. A clamping mechanism was built to hold the geosynthetic during pullout (see Figure 2.8). This clamp is made up of two 1.5" $(3.81 \mathrm{~cm})$ steel angles as well as one steel plate. The angle and plate thickness is 0.25 " (6.35 mm) to provide appropriate stiffness. This has shown to be sufficient in size and strength. The synthetic was wrapped around the plate,

which was secured between the two angles. This prevents synthetic/clamp separation and allowed a smooth transition from the box to the clamp. The clamping mechanism was linked to a load cell through a combination of connections as seen in Figure 2.9. This allowed the pullout force to be distributed to the load cell. The load cell was connected to a worm gear screw jack that provided the needed force to displace the material.

A guide system was positioned to avoid clamp and geosynthetic rotation during testing (see Figures 2.8 and 2.9). This guide system allows the clamp to be conveyed across two steel rods $(3 / 8$ " diameter), one on each side, and gives additional stability to the pullout system. Each rod is greased before each test to reduce friction, and passes through the clamp, where it is fastened to the frame by two steel angles. Without this guide system rotational displacement could not be avoided and would result in unstable characteristics within the device. 


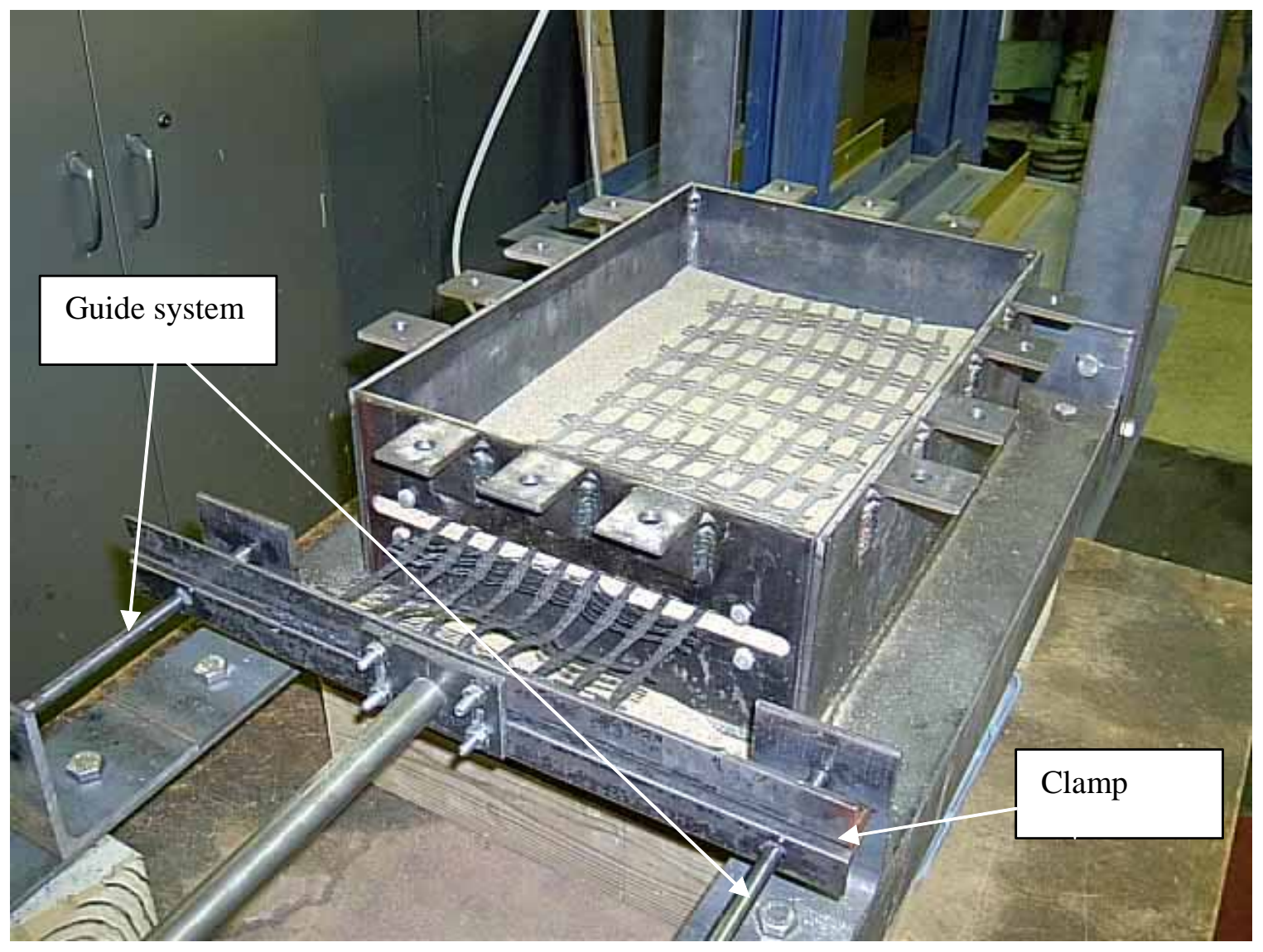

Figure 2.8: View of pullout box, clamp, and guide system. 


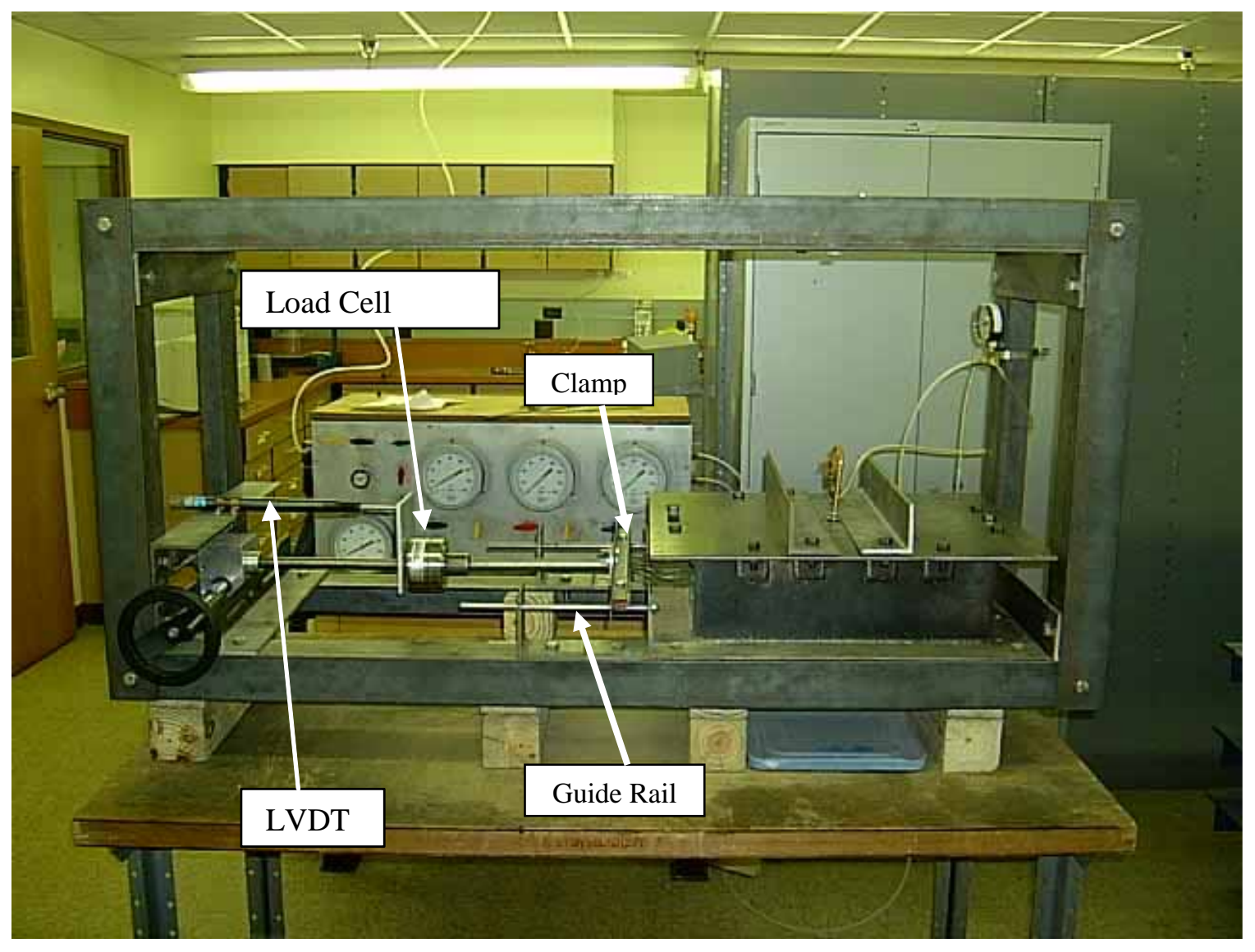

Figure 2.9: View of entire pullout device. 
Normal pressure was applied to the reinforced soil-geosynthetic system by two identical confining air bags. One bag was placed in the bottom of the pullout box and the other bag was placed on top of the reinforced soil inside the pullout box. The air bags were assembled manually in the laboratory by folding $1 / 16$ " thick rubber in such a way that an air pocket was formed between the rubber layers and the ends were glued together. These airbags were very reliable and performed well under pressurized conditions. Positioning of the air bags in box A can be seen in Figure 2.10 a schematic of the entire pullout device containing pullout box A. A schematic of the air bag can be seen in Figure 2.11.
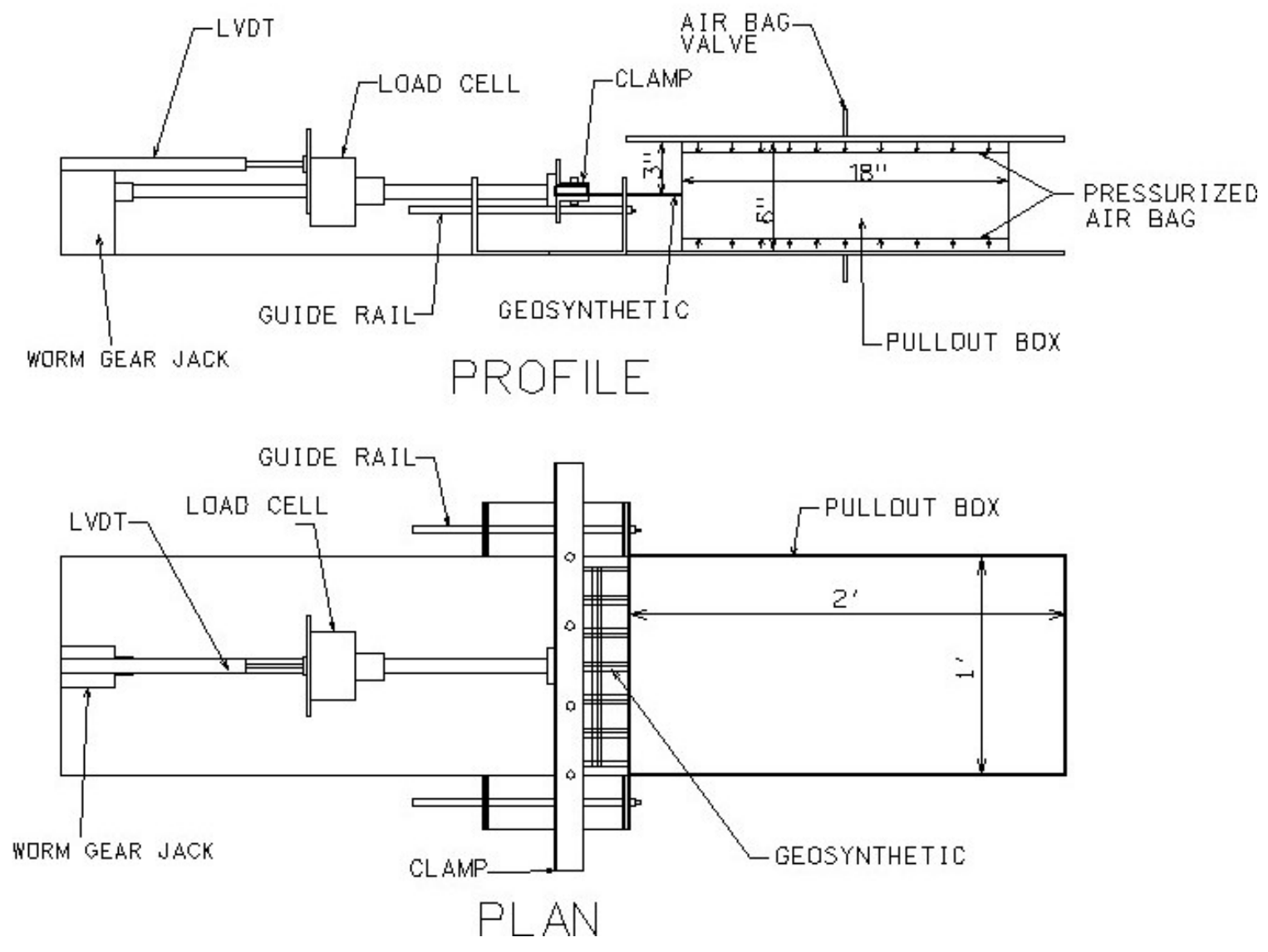

Figure 2.10: Schematic of pullout device A. 


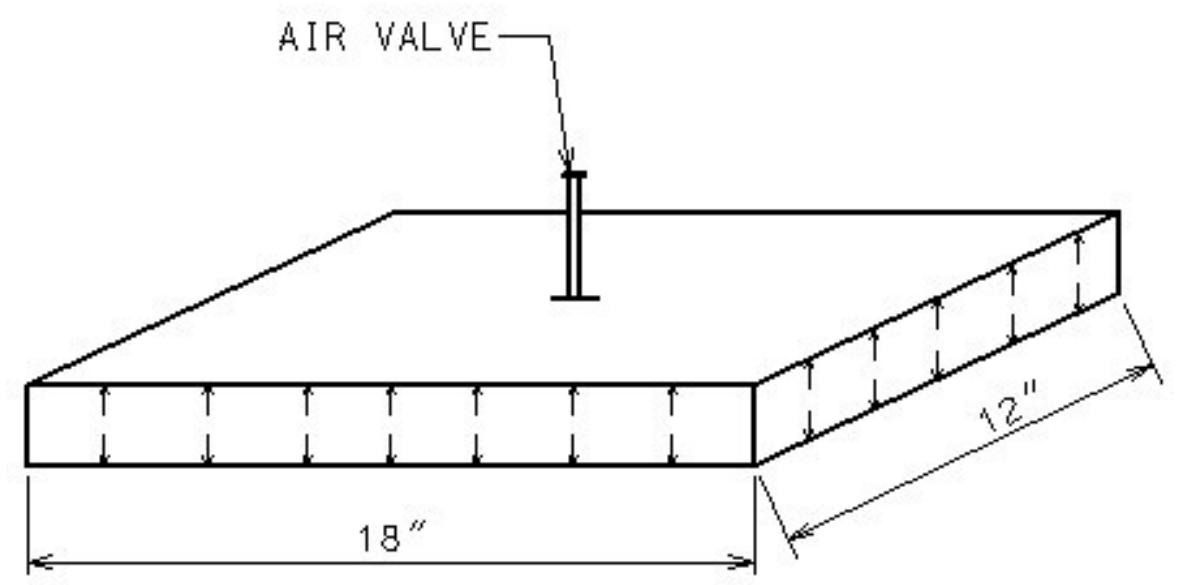

Figure 2.11: Schematic of pressurized air bag for pullout box A.

Complete assembly of the pullout device can be seen in Figure 2.9. This consisted of bolting together the frame that surrounds the box and instrumentation and setting up the main connection from the jack to geosynthetic material. The connection was made up of a clamp, steel rod, load cell, and jack extension. The clamping mechanism was adjusted several times in order to reach the needed stiffness.

Design of the pullout device with box B was based on the design of the existing device. All components included in the existing device are present in the larger device. The only major difference is the method of displacement. Pullout displacement, when using box B, was done using a variable speed motor. This ensured a constant displacement rate and proved to be reliable. Components were simply scaled up in size for the larger device due to the expected increase in pullout load. See Figure 2.12 and 2.13 for complete views of the larger pullout device. 


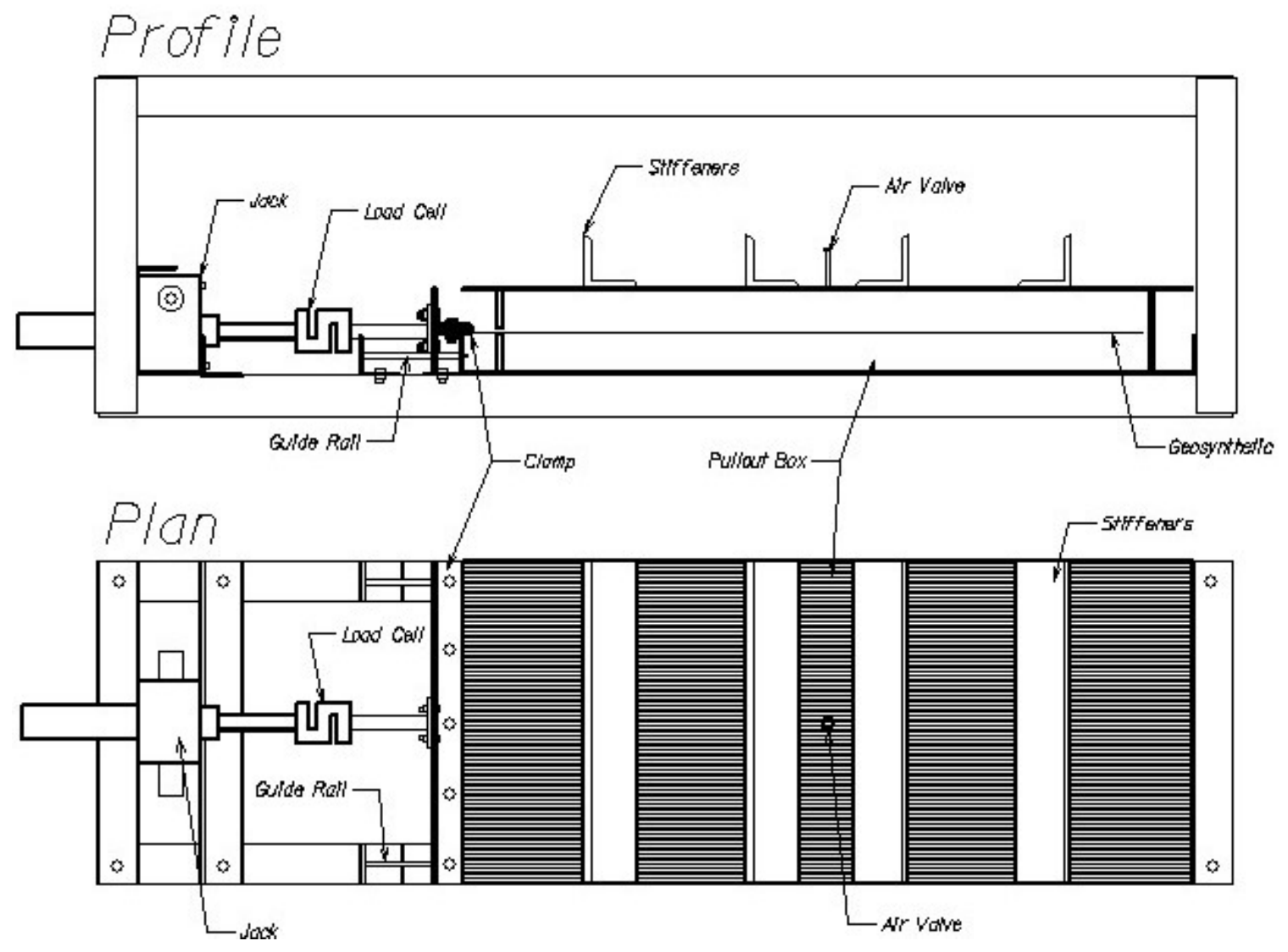

Figure 2.12: Schematic of large pullout device. 


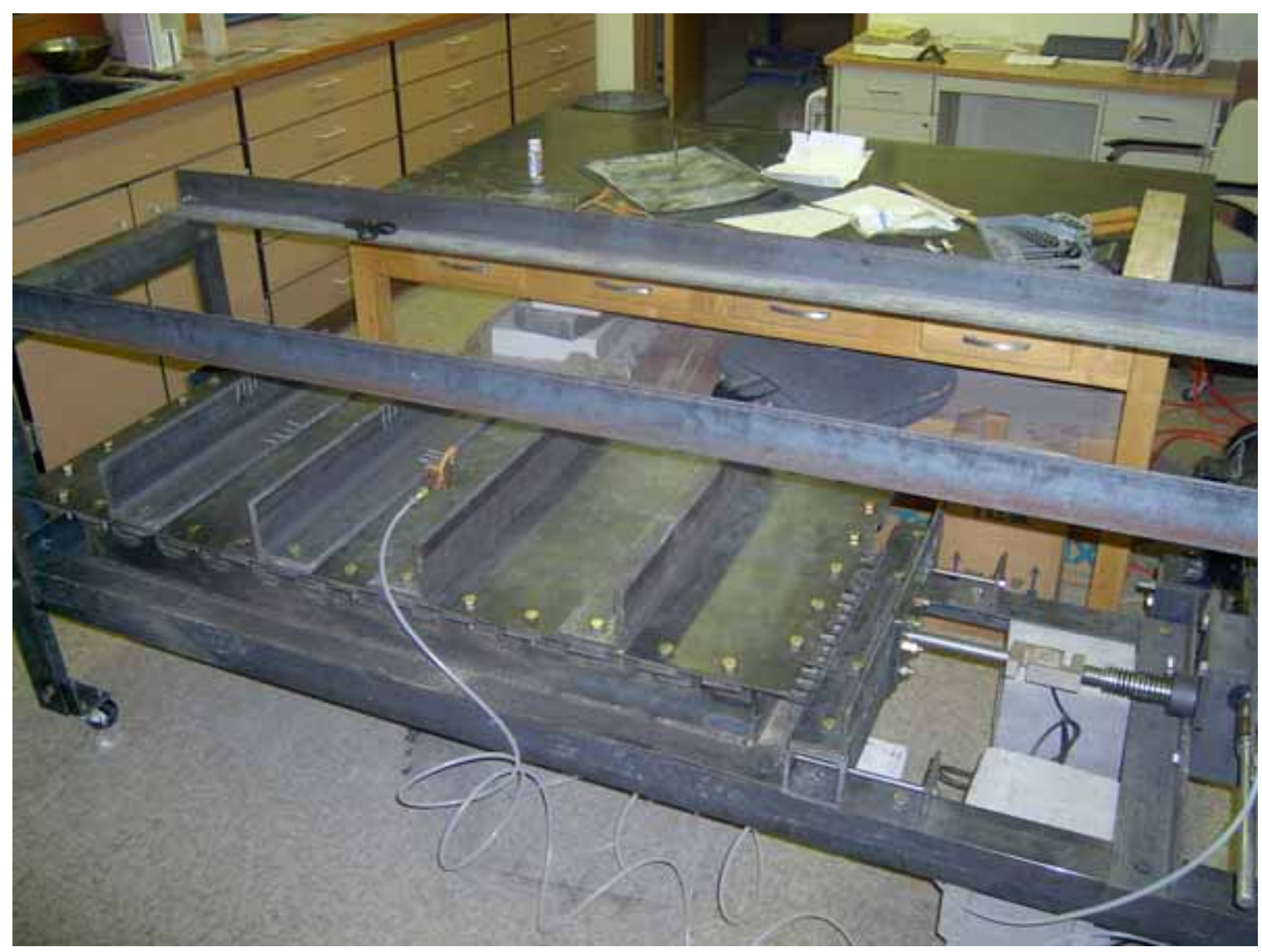

Figure 2.13: View of pullout device containing pullout box $B$.

\subsection{Instrumentation used for Pullout Testing}

For the pullout device with box A an LVDT was mounted above the jack and measured linear displacement while the load cell simultaneously measured the direct pullout force. This enabled the determination of a stress-strain relationship. The load cell and LVDT were both connected to separate display read-out units. A Transtek, Inc. Model 1003-S0100 is used in conjunction with the LVDT and initially a Lebow Products EATON model No. 7530 was used with the load cell. However, this load cell read-out unit began to malfunction so the voltage output from the load cell was then read by a voltmeter and converted into a force. This load cell as well as the load cell used with the larger pullout device was calibrated with the voltmeter by simply placing weights on the load cell and reading the voltage output. This enabled a linear relationship to be presented as shown in Figure 2.14. 


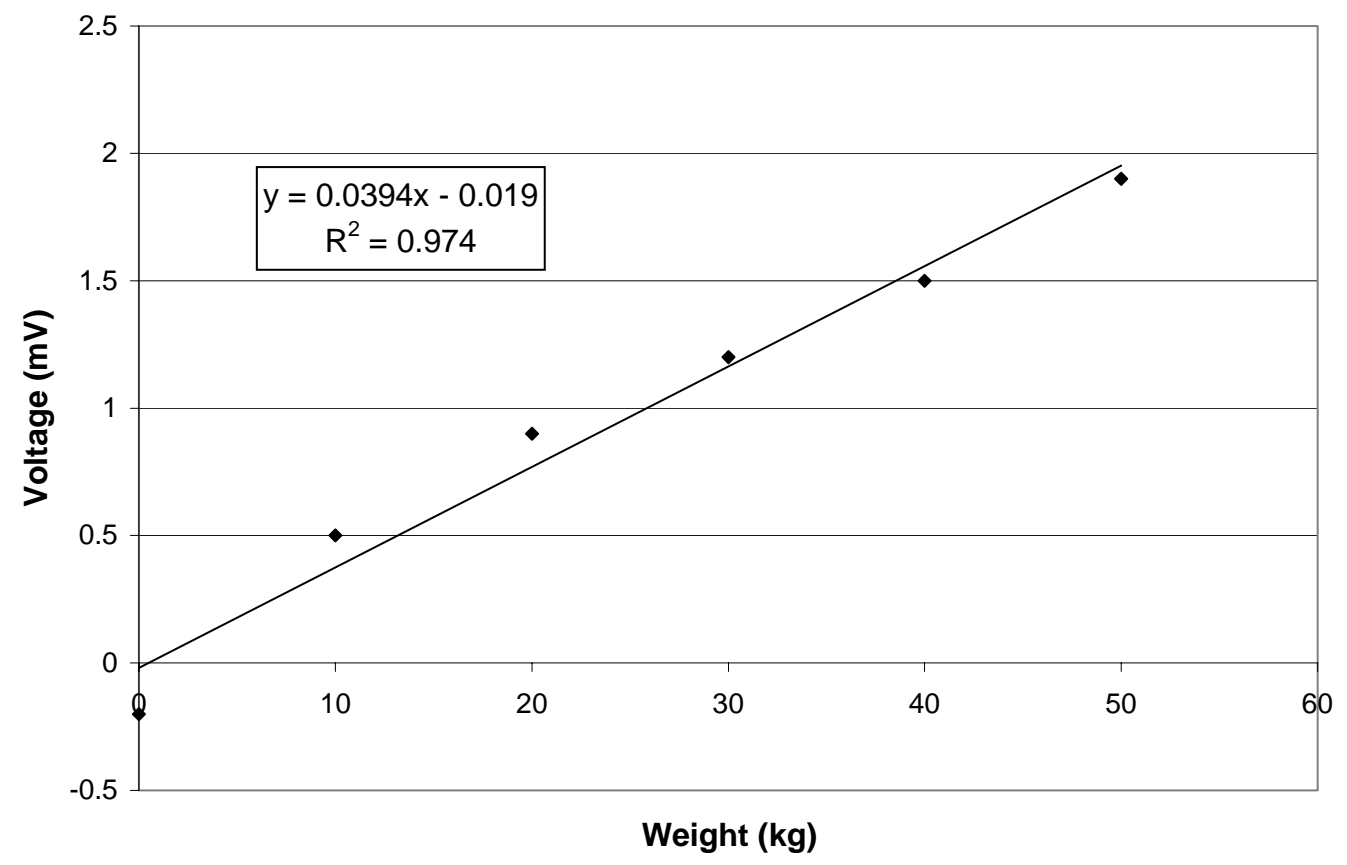

(a)

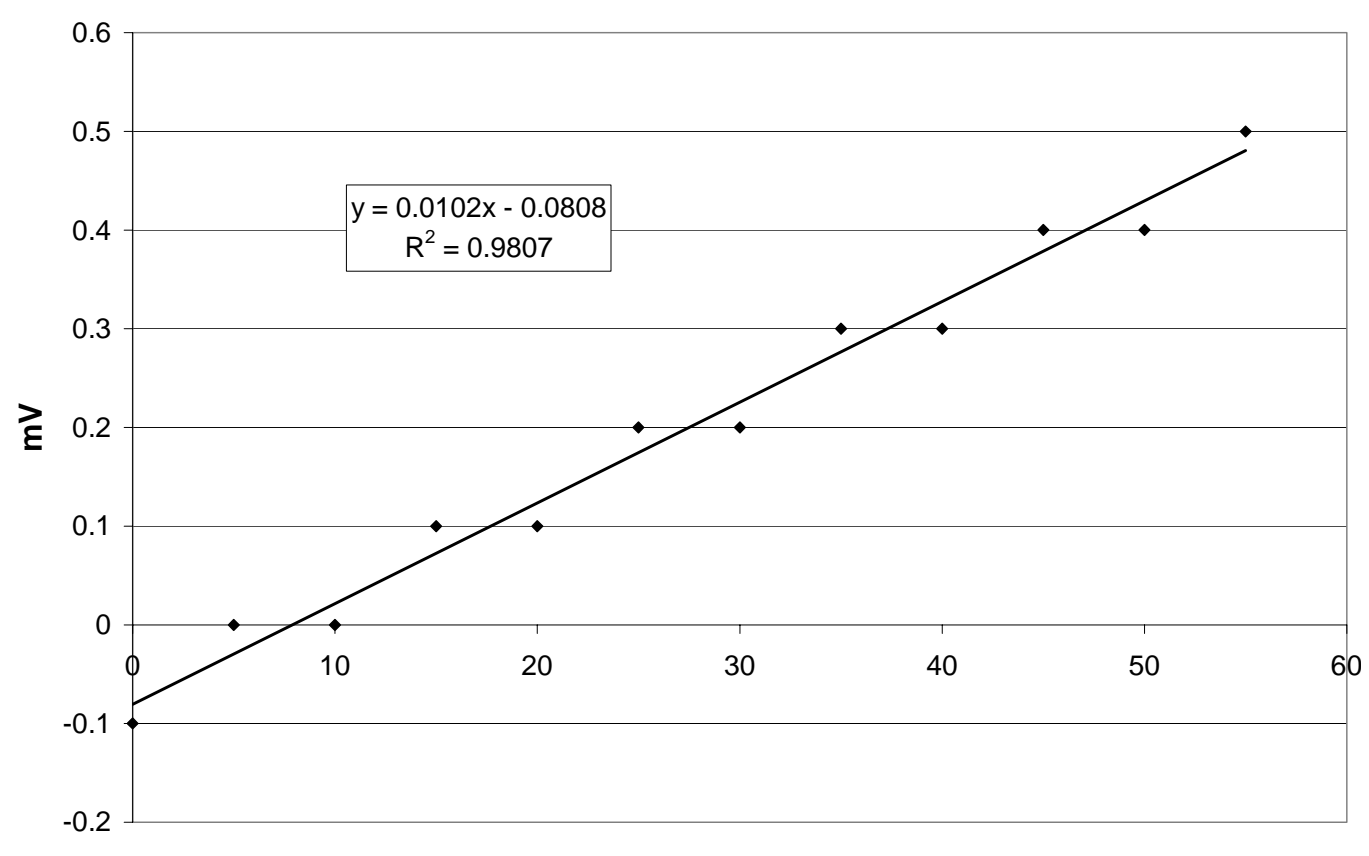

Weight (kg)

(b)

Figure 2.14: (a) Calibration of load cell and voltmeter for pullout box $A$ and (b) Calibration of load cell and voltmeter for pullout box $B$. 


\section{CHAPTER 3: METHODOLOGY}

\subsection{Direct Shear Testing}

A standard direct shear device with contact area of $0.01 \mathrm{~m}^{2}$ was used for all direct shear testing. The horizontal displacement was measured with an electronic dial gauge and the shear force was determined with a loading ring. Data collection for direct shear testing was done exclusively by a data acquisition system. A constant rate of displacement of $2 \mathrm{~mm} / \mathrm{min}$ was used for all tests. A variable speed motor supplied this displacement rate.

Tests were performed on a soil-soil interfaces and sand-geosynthetic interfaces. Three geosynthetics were used. One woven geogrid, one knitted geogrid and one nonwoven needle-punched geotextile. For each specimen configuration two tests were run to ensure reliability. A new geosynthetic sample was used for each test to avoid any fatigue in the sample. A minimum of three normal stresses were used for all interfaces in order to create a failure envelope graph. These normal stresses are $35.3 \mathrm{kPa}$ (5.1 psi), $69.6 \mathrm{kPa}(10.1 \mathrm{psi})$ and $103.9 \mathrm{kPa}(15.1 \mathrm{psi})$. These values were chosen because they are the closest values attainable to 5 psi (34.5 kPa), 10 psi (69 kPa), and 15 psi (103.4 kPa), which are the normal stress values used for pullout testing in the present study.

\subsubsection{Material Selection for Direct Shear Testing}

Three soil types were used for all direct shear testing. Natural sand was selected as the sand type in direct shear tests for determining soil-geosynthetic interface properties. The grain size distribution of the sand used in this study is shown in Figure 3.1. As seen in this figure, the sand is a poorly graded material with $\mathrm{D}_{10}$ equal to approximately $0.17 \mathrm{~mm}$.

The second and third soils that were used in this study have a mixture of the same natural sand and clay (Kaolinite). Different percentages of clay were added to the sand in

order to achieve workable silt and clay materials. Several mixtures were evaluated before 
choosing a mixture for further testing. Soil classification was done using both the AASHTO and USCS methods. Workability and soil class were the two major contributing factors in making the decision for a final soil mixture.

Four different mixtures were considered when choosing an appropriate silt and clay for this test program. The first mixture was made up of 15\% clay and $85 \%$ sand. This soil was classified by AASHTO as A-2-4 "silty sand" and SM-SC "silty clayey sand" by USCS. The second mixture consisted of $25 \%$ clay and $75 \%$ sand. This soil was also classified by AASHTO as A-2-4 "silty sand" and SM-SC "silty clayey sand" by USCS. Because the mixture with $15 \%$ clay has a greater workability than that of the $25 \%$ clay and both mixtures were classified as silts it was chosen as the silt that would be used in this study. A grain size distribution for this silt can be seen in Figure 3.2.

The third mixture was made up of 35\% clay and $65 \%$ sand. This soil was classified as A-4 "silty soil” by AASHTO and SC "clayey sand" by USCS. The fourth and final mixture that was considered was made up of $40 \%$ clay and $60 \%$ sand. This material was also classified as SC "clayey sand" by USCS and classified as A-6 "clayey soil” by AASHTO. A percentage equal to $35 \%$ clay was the minimum for a soil to be considered a clay material under the AASHTO classification system. For this reason and because the $35 \%$ clay mixture has greater workability it was chosen for the clay material to be used in this study. A grain size distribution for this clay can be seen in Figure 3.3. 


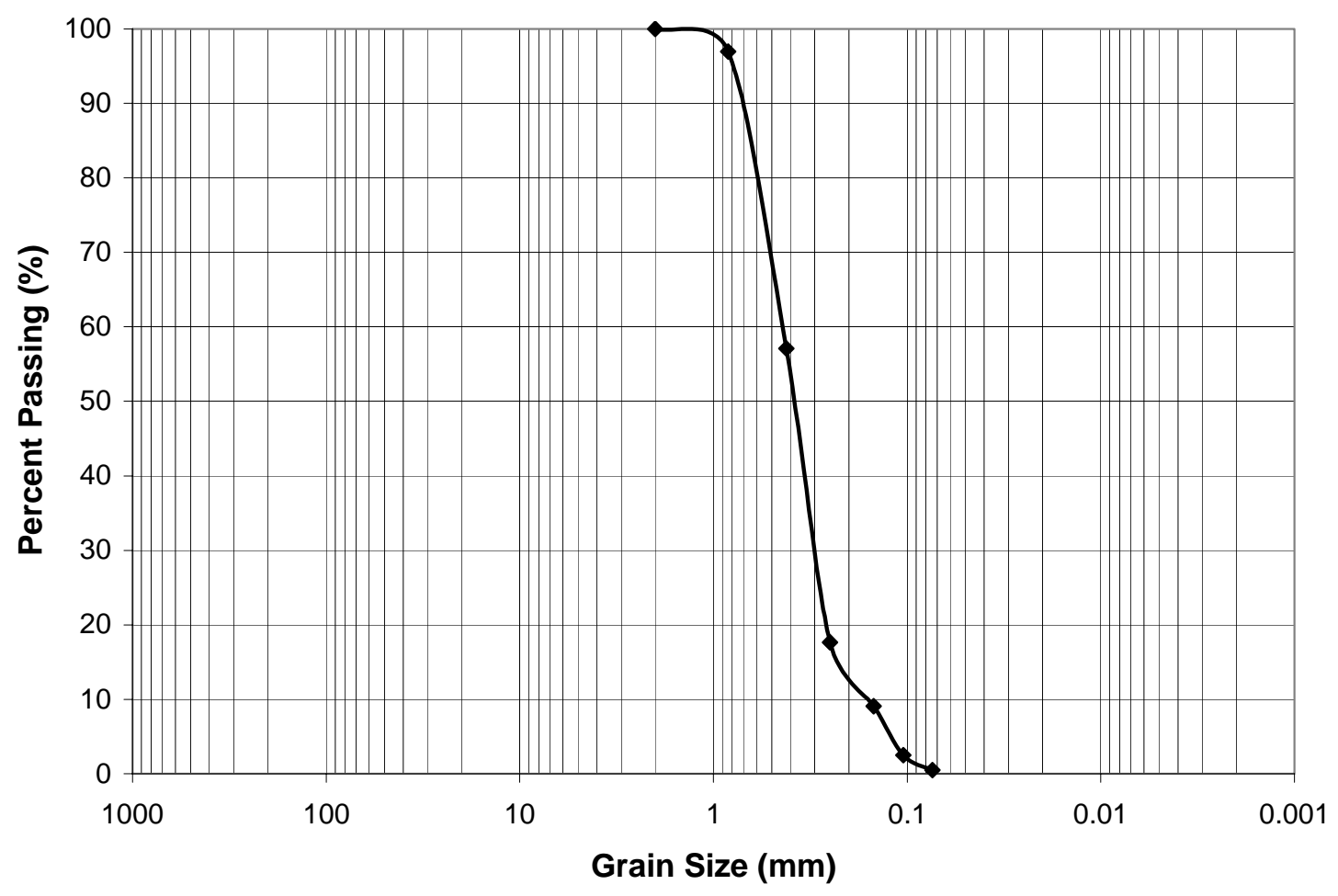

Figure 3.1: Grain Size Distribution for sand used in Direct Shear tests. 


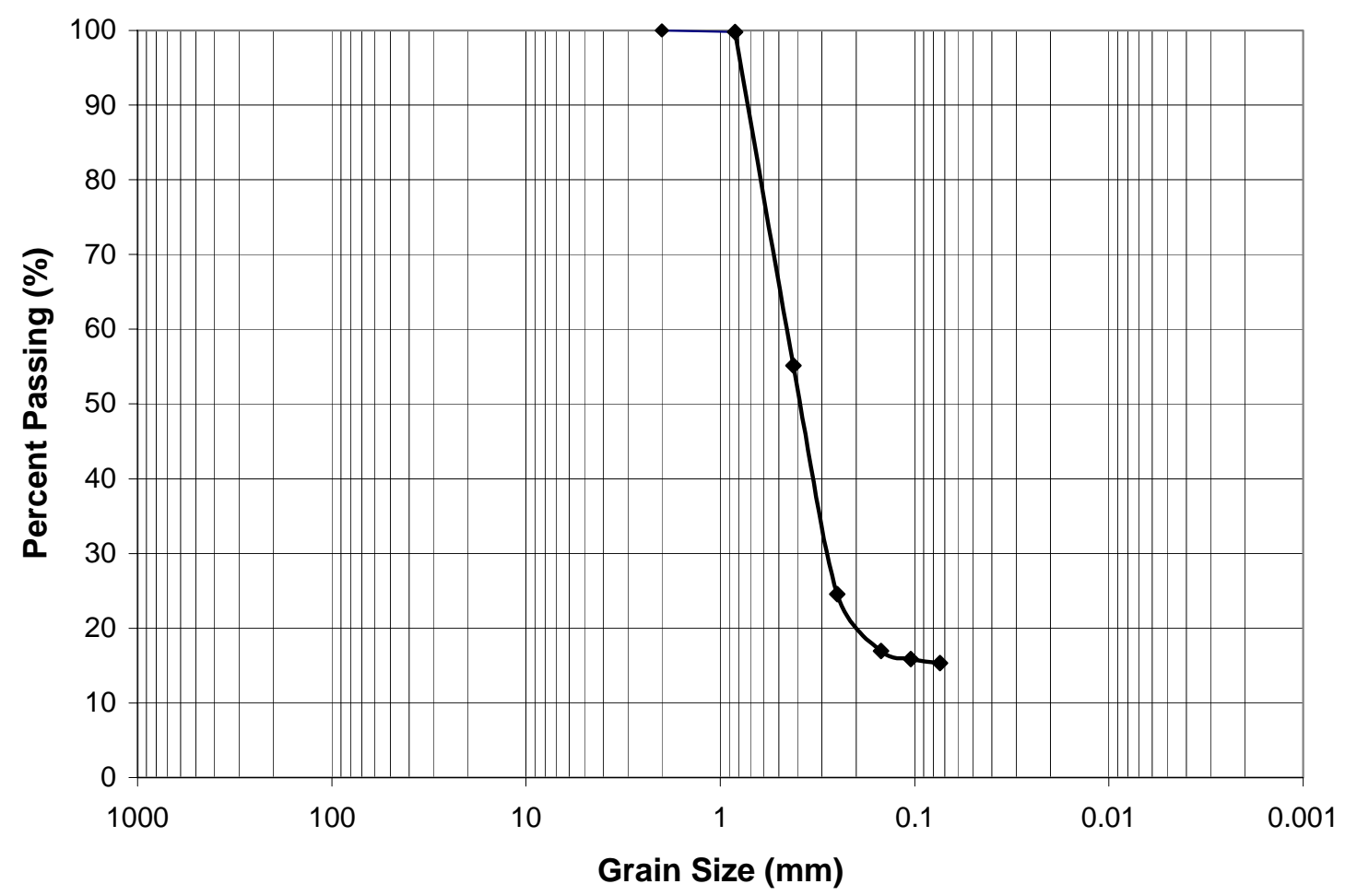

Figure 3.2: Grain Size Distribution for silt used in Direct Shear tests. 


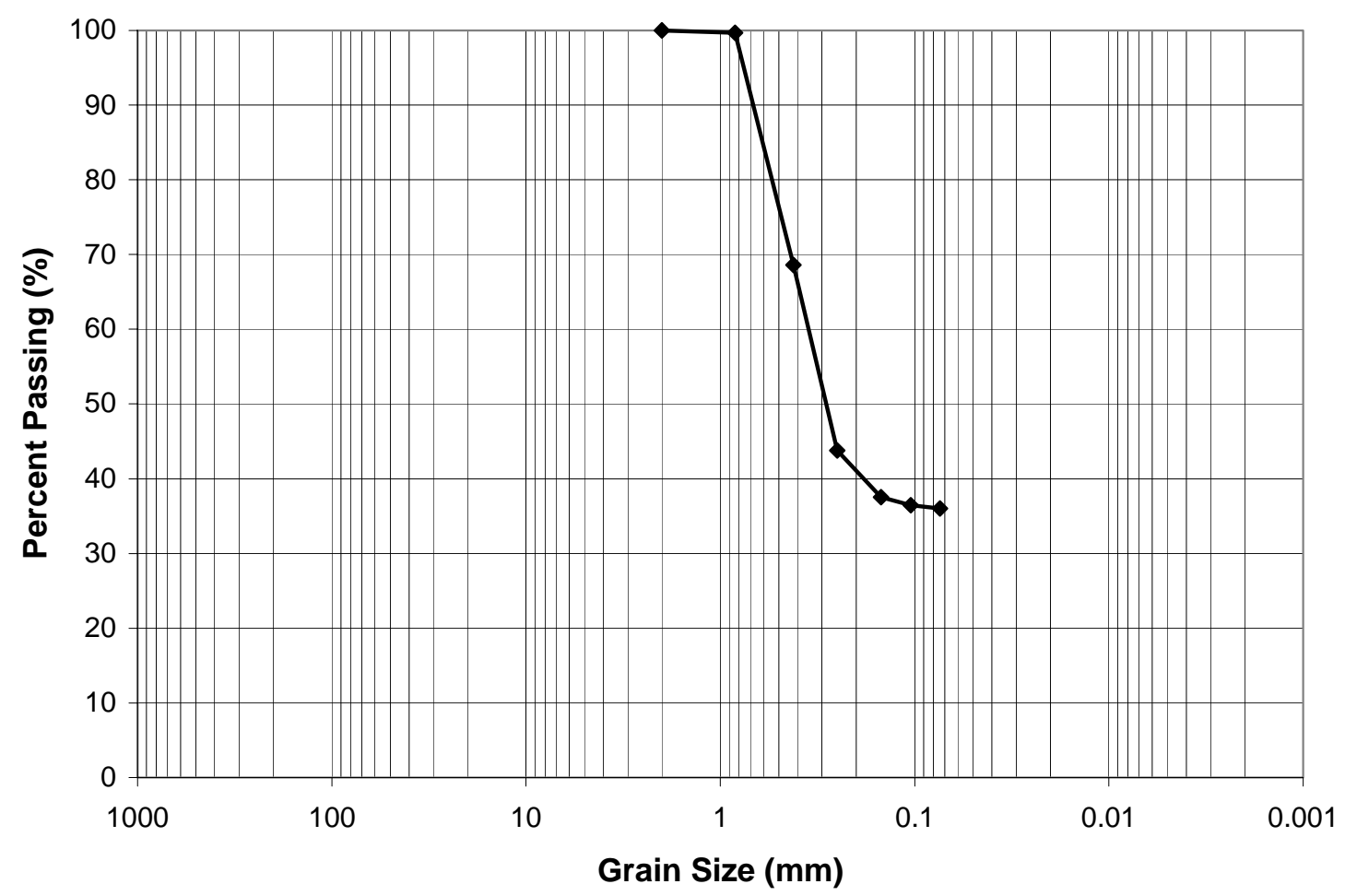

Figure 3.3: Grain Size Distribution for clay used in Direct Shear tests. 
The geosynthetic materials, which were selected for direct shear testing, consist of two geogrids and one geotextile. The two geogrids are made up of polyester with a polymeric coating. Both geogrids are uniaxial materials which means they are made to function in one direction. One is a woven material (material A) and the other is knitted (material B), see Figures 3.4 and 3.5. The geotextile used in this study (material C) is a polypropylene, nonwoven, needle-punched fabric, see Figure 3.6. Unlike geogrids, geotextiles have no apertures on their surface. These geosynthetics were selected because of their different characteristics. Effects of these properties are explored in the present study. Properties of these geosynthetics are found in Table 3.1.

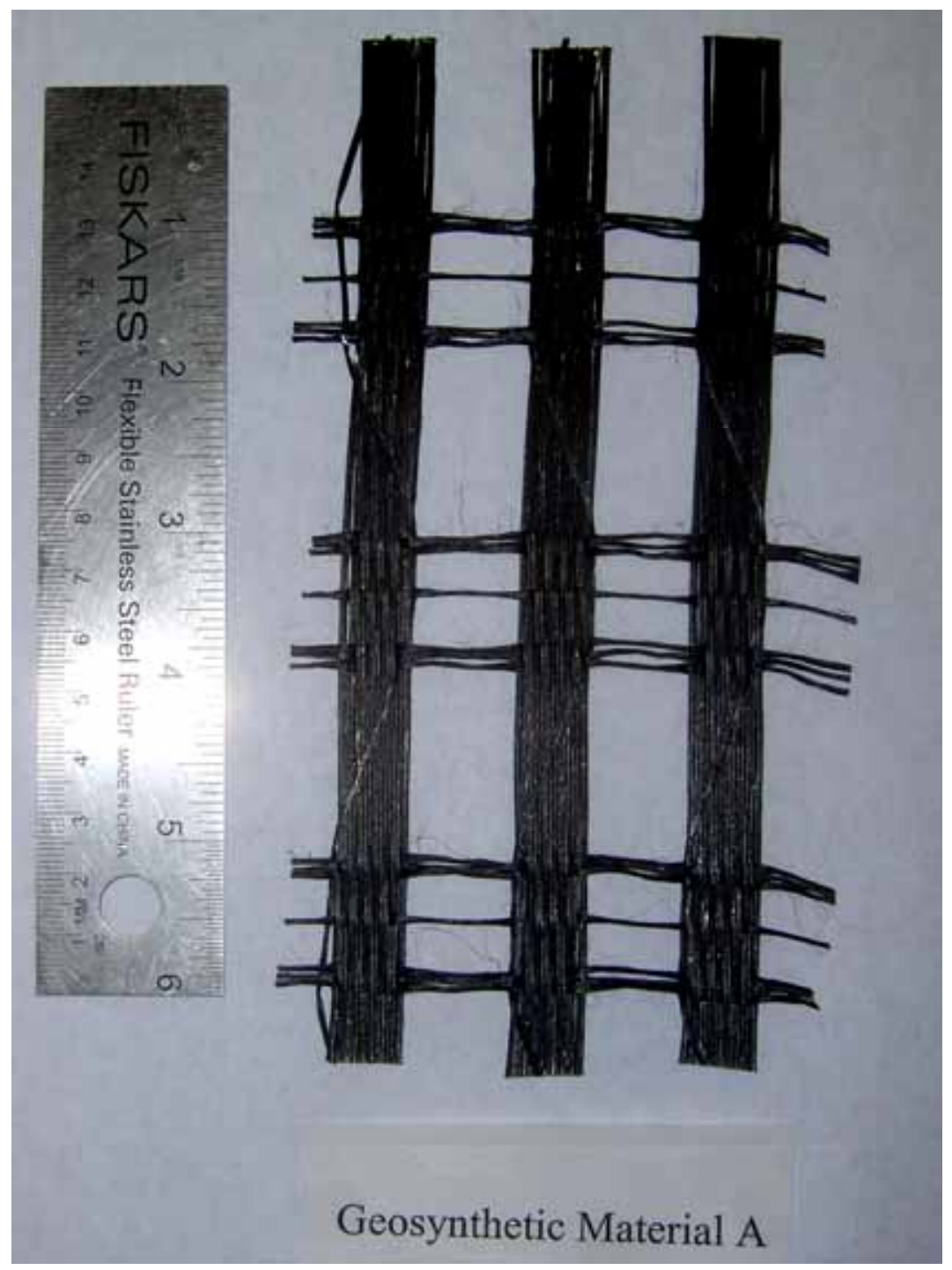

Figure 3.4: Sample of geosynthetic material A. 


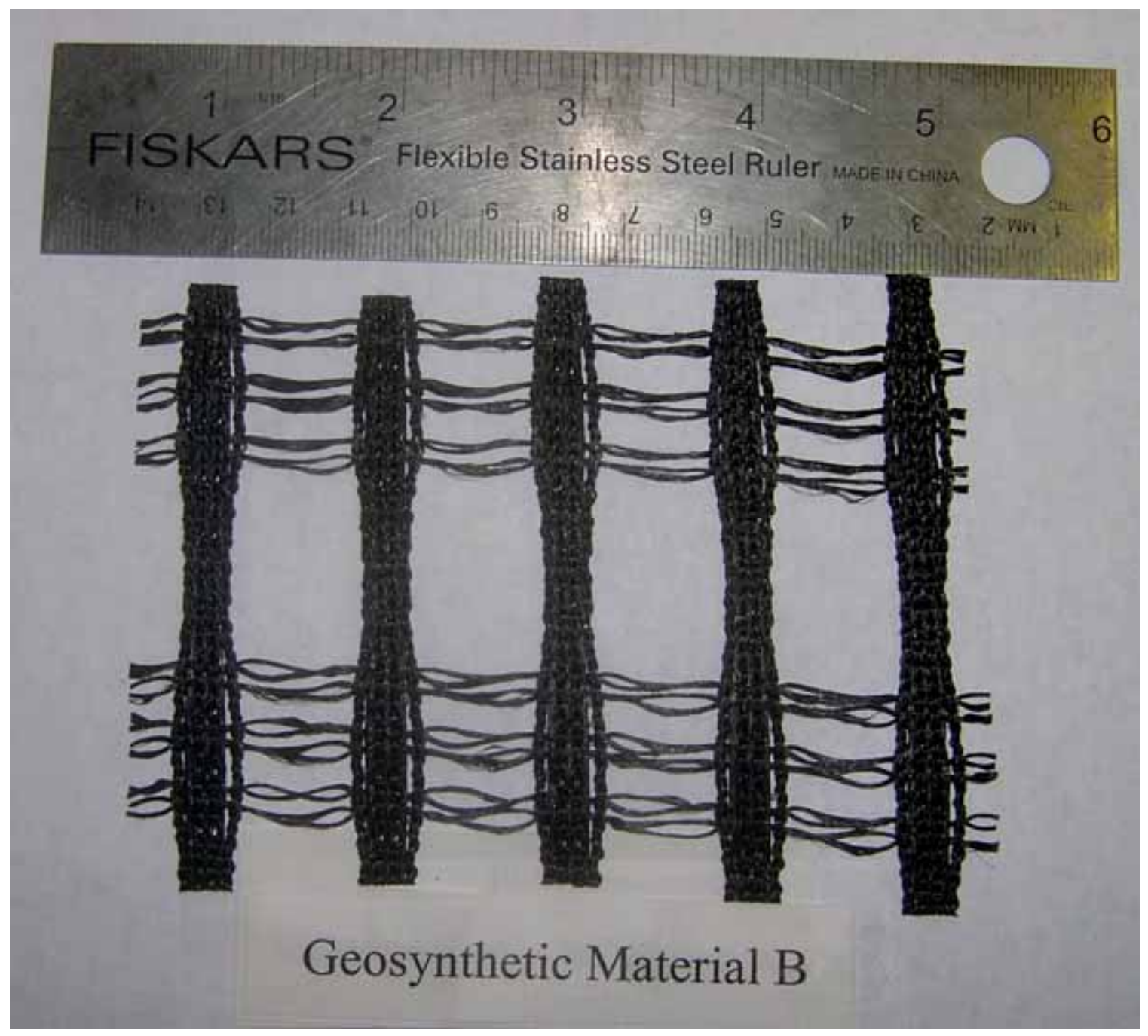

Figure 3.5: Sample of geosynthetic material B. 

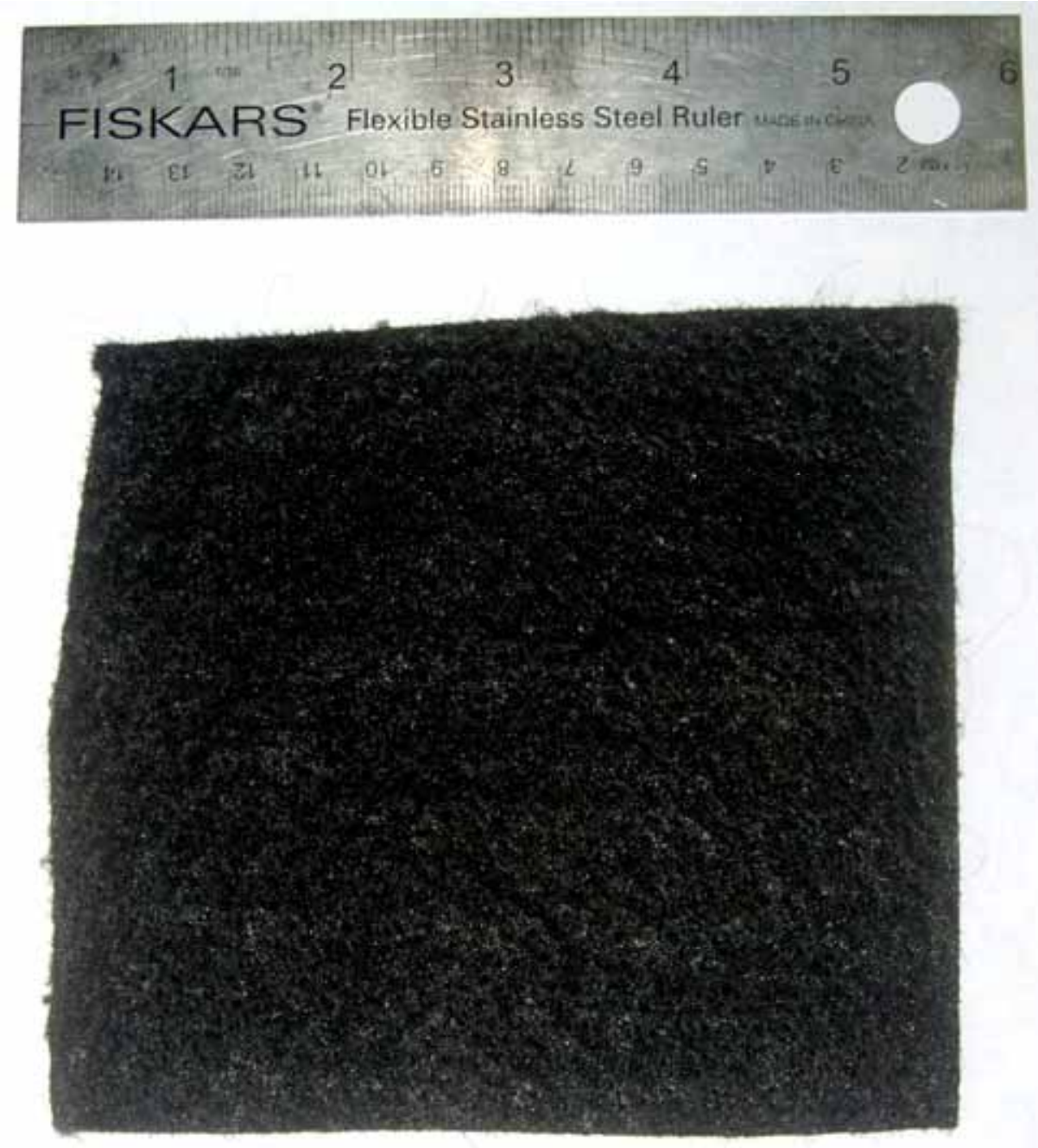

Geosynthetic Material C

Figure 3.6: Sample of geosynthetic material C. 
Table 3.1: Properties of geosynthetic materials.

\begin{tabular}{|c|c|c|c|c|}
\hline $\begin{array}{c}\text { Geosynthetic } \\
\text { Material }\end{array}$ & $\begin{array}{c}\text { Tensile } \\
\text { Strength } \\
(\mathrm{kN} / \mathrm{m})\end{array}$ & $\begin{array}{c}\text { Grid } \\
\text { Aperture } \\
\text { Size, MD } \\
(\mathbf{m m})\end{array}$ & $\begin{array}{c}\text { Grid } \\
\text { Aperture } \\
\text { Size, XMD } \\
(\mathbf{m m})\end{array}$ & $\begin{array}{c}\text { Mass per } \\
\text { Unit Area } \\
\left(\mathrm{g} / \mathrm{m}^{2}\right)\end{array}$ \\
\hline$A$ & 120 & 65 & 20 & 415 \\
\hline B & 35 & 40 & 25 & 170 \\
\hline C & 0.36 & N/A & N/A & $310^{*}$ \\
\hline
\end{tabular}

*Value was calculated in laboratory.

\subsubsection{Placement of Materials for Direct Shear Testing}

When testing soil-soil interfaces the soil was simply poured into the direct shear box in layers. Each layer was then leveled, and lightly compacted manually until desired height of soil was reached. The weight and volume of soil used for each test was recorded. This was done to calculate the density of the soil.

When testing soil-geogrid (materials A and B) interfaces soil was placed in the bottom half of the direct shear box and manually compacted. One end of the geogrid was clamped to the traveling section of the direct shear box. The other end was then folded over the bottom container and clamped to the direct shear frame. The framing clamp was removed when the normal loading was applied so no interference with the traveling container would take place. The material was folded in the direction of movement so no slack would occur in the geogrid during the test. This method proved to be reliable and consistent with ASTM D-5321 standards (Standard Test Method for Determining the 
Coefficient of Soil and Geosynthetic or Geosynthetic and Geosynthetic Friction by the Direct Shear Method). See Figures 3.10 and 3.11.

When testing sand-geotextile (material C) interface, sand was first placed in the bottom half of the direct shear box and manually compacted. To create a material C-sand interface the fabric was wrapped around and fixed to a wooden block and inserted into the top half of the direct shear box. This allowed a material C-sand interface to exist. Procedures for all of these methods are outlined in the following section.

\subsubsection{Procedures for Direct Shear Testing}

The procedure for direct shear testing of soil-soil interfaces is given below.

1. Connect direct shear frame with mounting screws, but do not tighten completely. Provide spacing of approximately $1 / 8$ " with spacing screws. Tighten mounting screws to present a uniform gap on all sides of the box (see Figure 3.7).

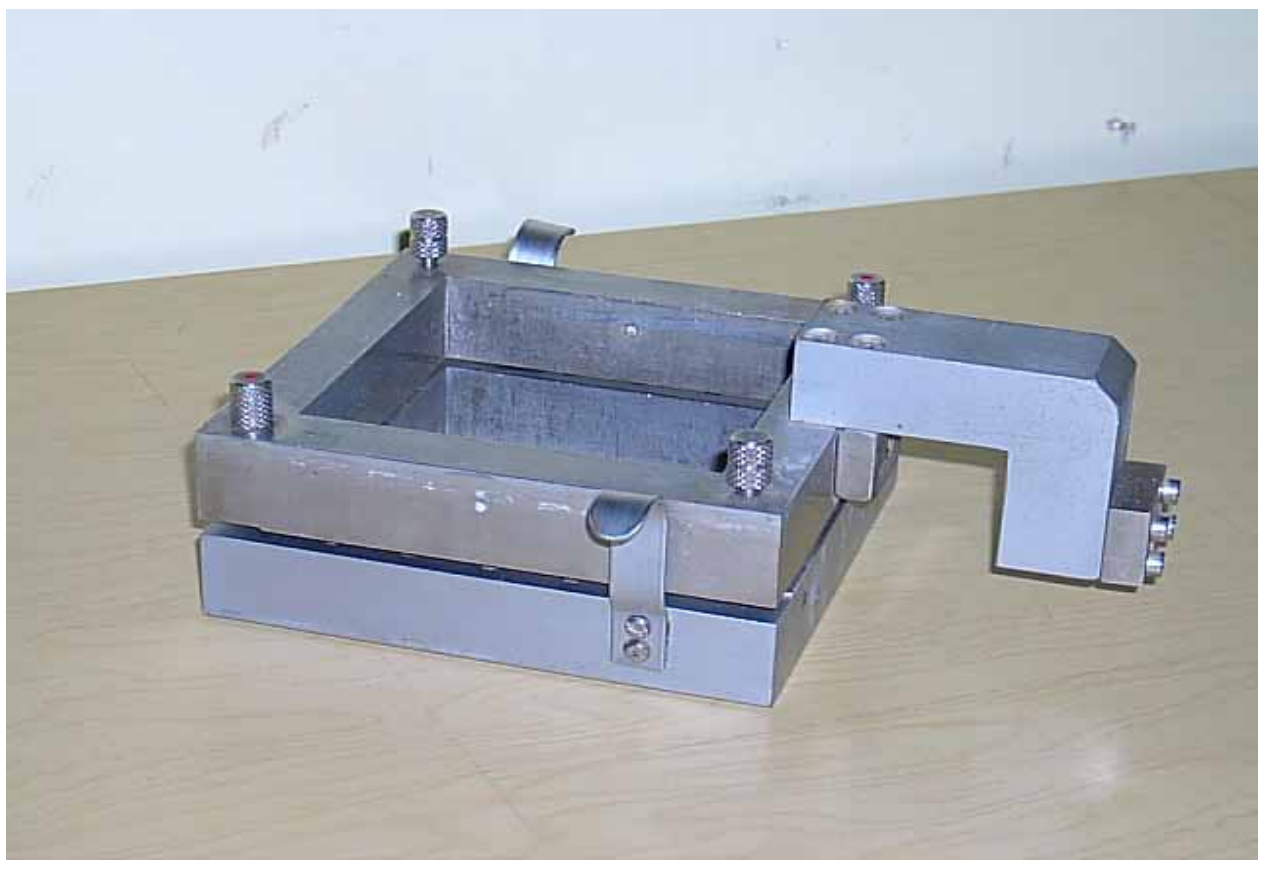

Figure 3.7: Shear box with mounting screws to present uniform gap. 
2. Put the shear box inside frame and tighten frame screws (see Figure 3.8).

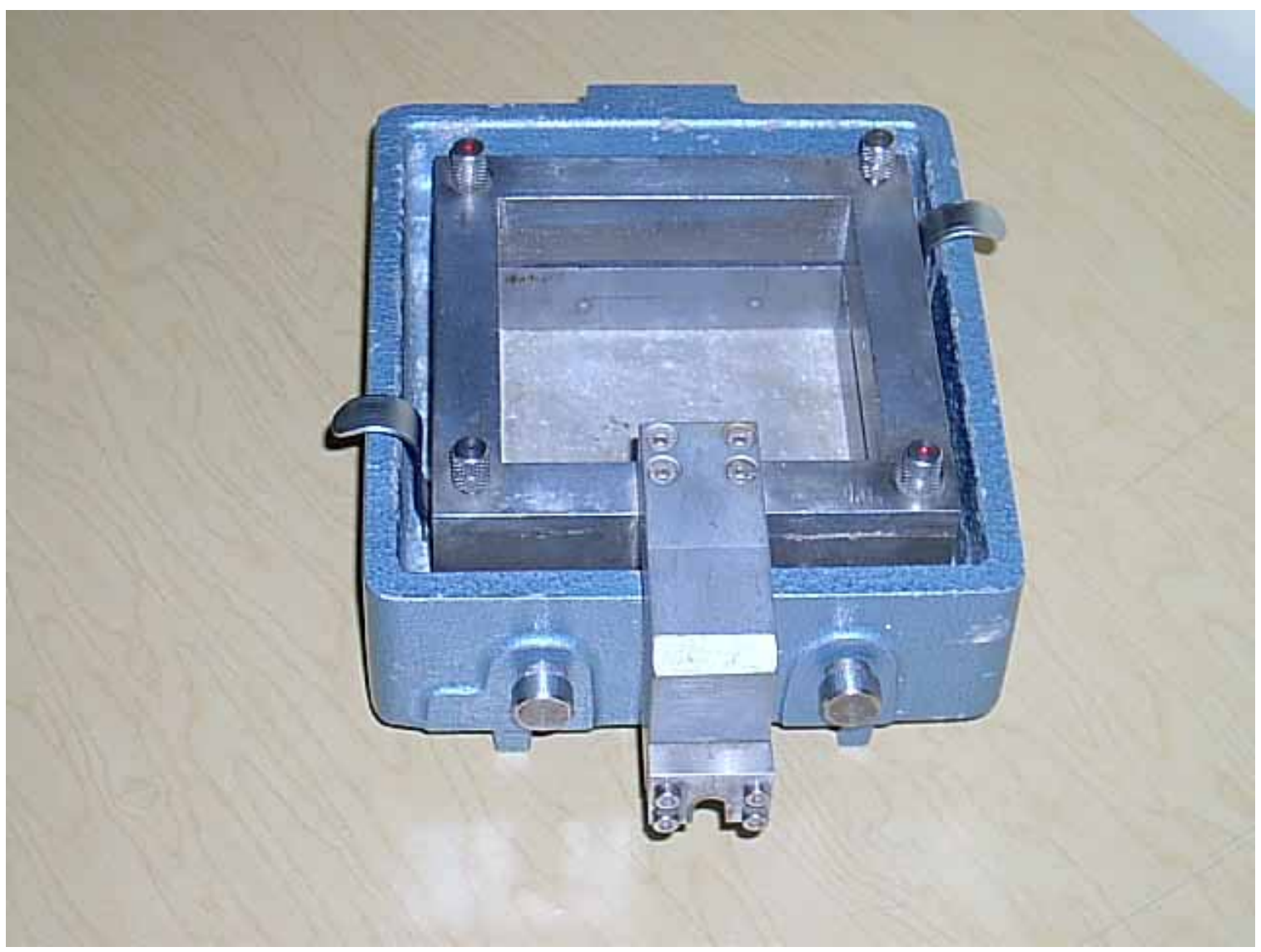

Figure 3.8: Shear box inside frame with framing screws tight.

3. Insert bottom plate, porous stone then grooved plate (grooves parallel to motion) in bottom of direct shear box. Place soil in even layers and level and compact each layer. Bring soil to desired height so equal amounts are distributed above and below box gap.

4. Place plate, porous stone and loading cap on top of the soil sample. 
5. Place hanger on box and place assigned weight on arm hanger (see Figure 3.9).

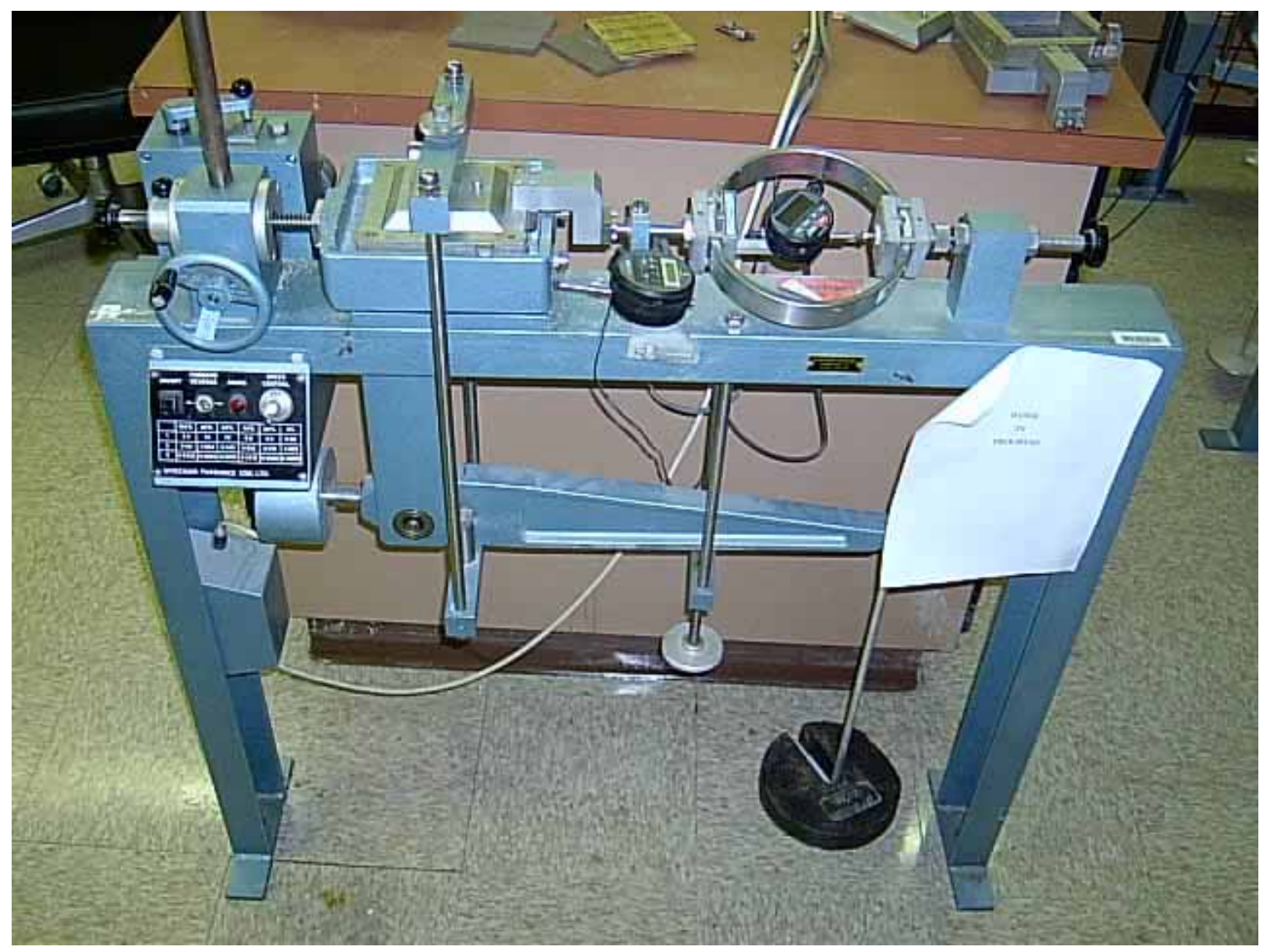

Figure 3.9: Complete assembly of shear device.

6. Remove the mounting and spacing screws before you begin to shear the sample.

7. Set the units on horizontal displacement and loading ring device to inches and obtain an initial reading by advancing the wheel while in neutral. 
8. Set the appropriate speed on shear device, shift device into selected gear and clear the readings on horizontal displacement and force gauges.

9. Clear old data from the computer. Start the test on computer, by selecting "run", and then start motor on direct shear device.

10. Continue the test until a shear deformation greater than ten percent of the original length $(10 \mathrm{~cm})$ of the sample has been reached.

The procedure for direct shear testing of sand-geogrid interfaces is given below.

1. Acquire geogrid sample approximately $20 \mathrm{~cm}\left(7.87^{\prime \prime}\right)$ long and $10 \mathrm{~cm}\left(3.94^{\prime \prime}\right)$ wide.

2. Place geogrid and bottom half of direct shear box inside the direct shear frame (see Figure 3.10).

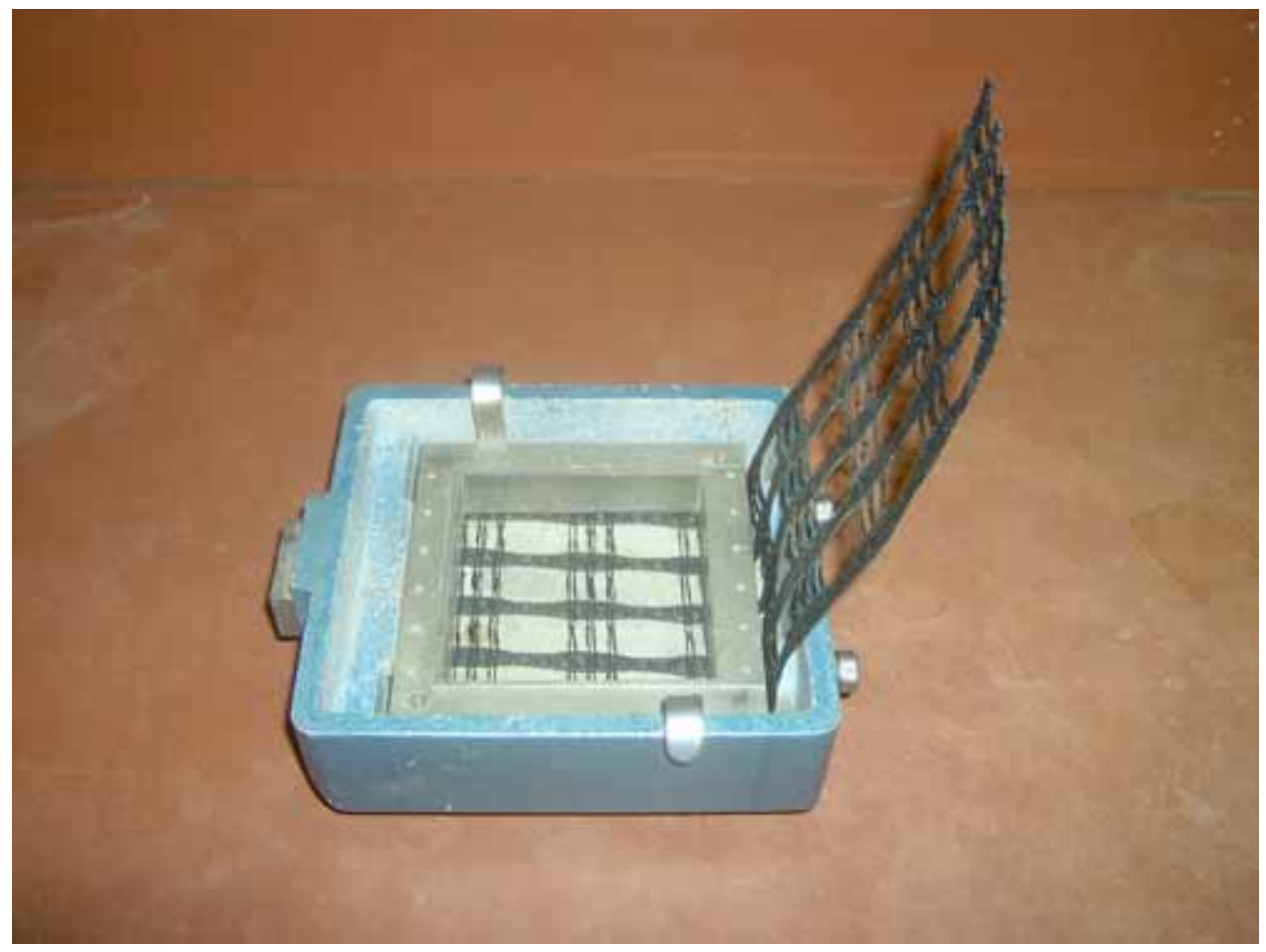

Figure 3.10: Direct shear box with geogrid. 
3. Tighten frame screws to hold direct shear box and geogrid in place.

4. Place soil in bottom half of direct shear box and manually level and compact soil.

5. Fold excess geogrid over the bottom half of direct shear box and soil. Clamp end of greogrid to direct shear frame so no slack is developed before test is run (see Figure 3.11).

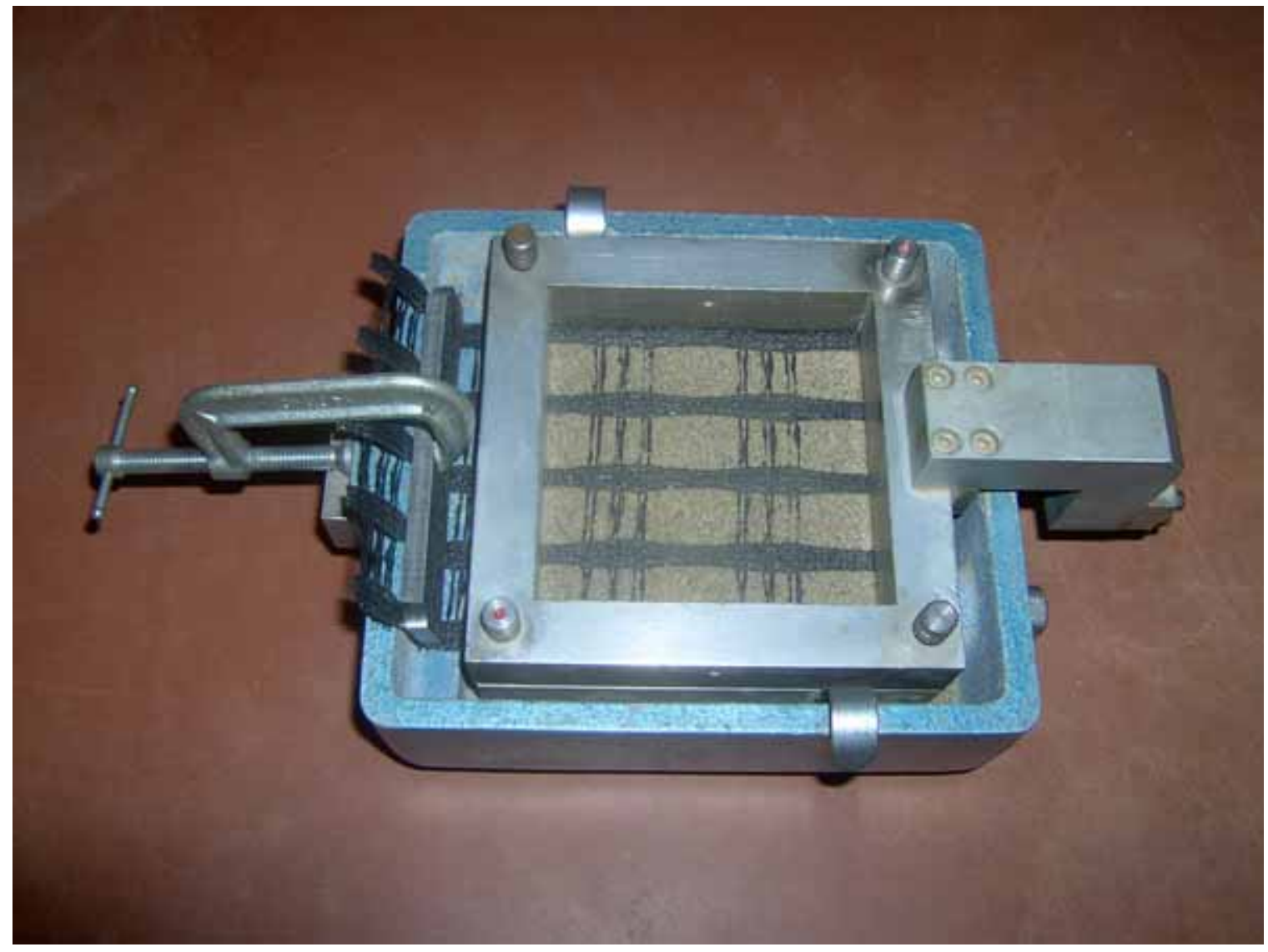

Figure 3.11: Direct shear box with geogrid clamped to frame. 
6. Place soil in top of direct shear box and level and compact soil.

7. Place plate, porous stone and loading cap on top of the soil sample.

8. Place hanger on box and place assigned weight on arm hanger (see Figure 3.9).

9. Remove the mounting and spacing screws before you begin to shear the sample.

10. Set the units on horizontal displacement and loading ring device to inches and obtain an initial reading by advancing the wheel while in neutral.

11. Set the appropriate speed on shear device, shift device into selected gear and clear the readings on horizontal displacement and force gauges.

12. Clear old data from the computer. Start the test on computer, by selecting "run", and then start motor on direct shear device.

13. Remove the clamp from end of geogrid so motion will not be restricted

14. Continue the test until a shear deformation greater than ten percent of the original length $(10 \mathrm{~cm})$ of the sample has been reached.

The procedure for direct shear testing of sand-geotextile interfaces is given below.

1. Acquire geotextile sample approximately $20 \mathrm{~cm}\left(7.87^{\prime \prime}\right)$ long and $20 \mathrm{~cm}$ wide.

2. Place bottom half of direct shear box inside the direct shear frame.

3. Place soil in bottom half of direct shear box and manually level and compact soil.

4. Place wood block with geotextile into top half of box (see Figure 3.12). 


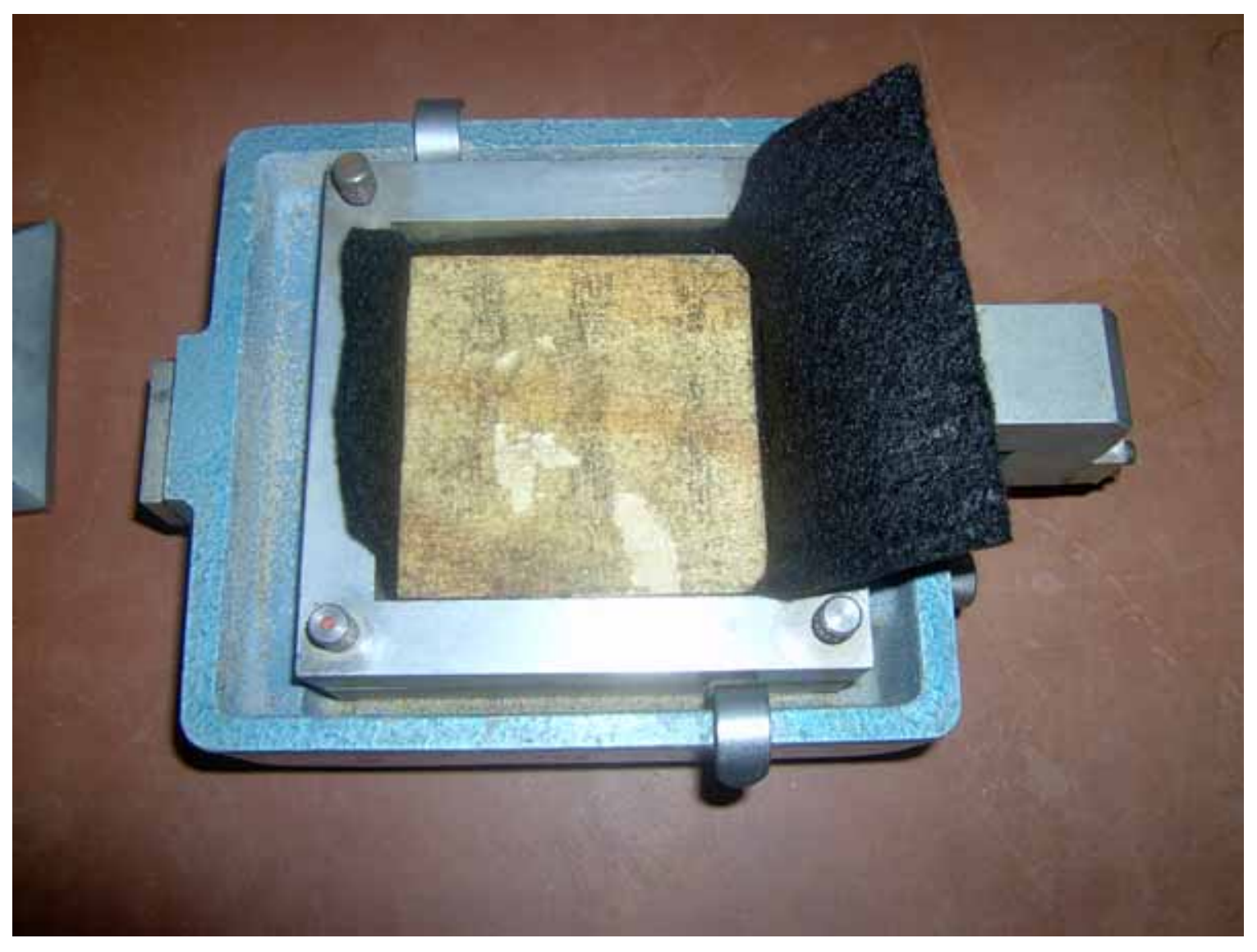

Figure 3.12: Direct shear box with wood block and geotextile.

5. Place plate, porous stone and loading cap on top of the soil sample.

6. Place hanger on box and place assigned weight on arm hanger (see Figure 3.9).

7. Remove the mounting and spacing screws before you begin to shear the sample.

8. Set the units on horizontal displacement and loading ring device to inches and obtain an initial reading by advancing the wheel while in neutral.

9. Set the appropriate speed on shear device, shift device into selected gear and clear the readings on horizontal displacement and force gauges.

10. Clear old data from the computer. Start the test on computer, by selecting "run", and then start motor on direct shear device.

11. Continue the test until a shear deformation greater than ten percent of the original length $(10 \mathrm{~cm})$ of the sample has been reached. 


\subsubsection{Calculations for Direct Shear Testing}

A data acquisition system was used to record the displacement and shear force applied to the specimen. A standard direct shear device with a square container was used for testing. Therefore the corrected area was needed. The corrected area is defined by the following equation [ASTM D5321, 1998]:

$$
A_{c}=A_{o}-(d W)
$$

where:

$$
\begin{aligned}
A_{c}= & \text { corrected area }\left(\mathrm{m}^{2}\right) \\
A_{o}= & \text { initial specimen contact area }\left(\mathrm{m}^{2}\right) \\
d= & \text { horizontal displacement }(\mathrm{m}) \\
W= & \text { specimen contact width in a direction perpendicular to that of } \\
& \text { shear force application }(\mathrm{m})
\end{aligned}
$$

For each shear force recorded a shear stress value was calculated. The following equation was used to calculate shear stress [ASTM D-5321, 1998]:

$$
t=\left(F_{s} / A_{c}\right)
$$

where:

$$
\begin{aligned}
t & =\text { shear stress }(\mathrm{kPa}) \\
F_{s} & =\text { shear force }(\mathrm{kN}) \\
A_{c} & =\text { corrected area }\left(\mathrm{m}^{2}\right)
\end{aligned}
$$


A maximum shear stress at or before ten percent strain was used to locate failure for each specimen. The strain equation used in this study was:

$$
\varepsilon=\frac{\Delta l}{l} \times 100
$$

where: $\quad \mathrm{e}=$ percent strain $(\%)$

$$
\begin{aligned}
& \mathrm{Dl}=\text { change in original length }(\mathrm{cm}) \\
& l=\text { original length }(\mathrm{cm})
\end{aligned}
$$

The normal loading was calculated by dividing the normal force applied by the corrected area. The normal force consisted of three plates inserted on top of the specimen, a hanger, and a combination of weights that were supported by the hanger. The weights that were applied to the specimen were multiplied by ten because of the effect of a moment arm on the direct shear device. The normal stress equation was:

$$
\sigma_{n}=\frac{W_{p}+W_{h}+\left(10 \times W_{w}\right)}{A_{c}}
$$

where:

$$
\begin{aligned}
& \mathbf{S}_{n}=\text { normal stress }(\mathrm{kPa}) \\
& W_{p}=\text { weight of plates }(\mathrm{kN}) \\
& W_{h}=\text { weight of hanger }(\mathrm{kN}) \\
& W_{w}=\text { weight of added weights }(\mathrm{kN}) \\
& A_{c}=\text { corrected area }\left(\mathrm{m}^{2}\right)
\end{aligned}
$$

Shear stress values at failure were averaged and plotted against the average of the two corresponding normal stress values at failure. These stress values were plotted to create the failure envelope. Once this graph was created a trend line was placed to obtain the angle of friction and effective cohesion. The trend line was forced through the origin of the graph when testing sand because sand has no cohesion. The effective cohesion is 
equal to the y-intercept of the trend line. The following equation was used to calculate the angle of friction [ASTM D-5321, 1998]:

$$
\delta_{p}=\tan ^{-1}\left(\omega_{p}\right)
$$

where: $\quad d_{p}=$ angle of friction corresponding to the peak shear stress (degrees)

$w_{p}=$ the coefficient of friction corresponding to the peak shear stress (slope of the trend line)

\subsection{Pullout Testing}

Two pullout boxes of different size were used in this study. This was done to explore the effects of boundary conditions and specimen size. The first box designed and built is the smaller of the two. Nearly all of the tests run in this study were done using this box. In this study the smaller pullout box will be referred to as "pullout box A" and the larger box as "pullout box B”.

When using box A the horizontal displacement was measured with an electronic LVDT and the shear force was determined with a load cell. Data collection for pullout testing was done manually by reading a load cell voltage display every $0.1^{\text {" }}$ of displacement. The displacement rate for pullout box A was done manually by turning a hand wheel. This was done at a rate approximately equal to $5 \mathrm{~mm} / \mathrm{min}$.

When using box B a load cell voltage display was read and converted into a force. The displacement was done using a variable speed motor. This motor was run at a constant rate of $5 \mathrm{~mm} / \mathrm{min}$ and a voltage was read every thirty seconds. This corresponds to one reading every $0.1^{\prime \prime}$ of displacement.

Tests were performed on soil-geosynthetic interfaces. Three geosynthetics were used. These are the same geosynthetics that were used for direct shear testing. For each specimen configuration two tests were run to ensure reliability. A new geosynthetic sample was used for each test to avoid any fatigue in the sample. Three normal stresses 
were used for all interfaces in order to create a failure envelope graph. These normal stresses were $34.5 \mathrm{kPa}(5 \mathrm{psi}), 69 \mathrm{kPa}(10 \mathrm{psi})$ and $103.4 \mathrm{kPa}$ (15 psi).

\subsubsection{Material Selection for Pullout Testing}

Sand, silt and clay were the three types of soils selected for pullout testing. The first of three soils used for pullout testing was a natural sand. This is the same sand used for direct shear testing. Its grain size distribution properties can be seen in Figure 3.1. The silt and clay materials used for pullout testing were also the same materials that were used for direct shear testing. Their grain size distribution can be found in Figures 3.2 and 3.3.

The silt and clay used for pullout testing was also tested with different moisture contents. Three different moisture contents were used: $0 \%, 10 \%$ and $15 \%$. The effects of these moisture contents are explored in this study. The geosynthetic materials used in pullout testing are the same materials used in the direct shear testing. These geosynthetic materials and their properties are discussed in Section 3.1.1. Their properties are summarized in Table 3.1.

\subsubsection{Placement of Materials for Pullout Testing}

The soil was placed in the pullout box in several layers then manually leveled and compacted. Each layer was approximately 1.5" thick. This was done until the midpoint of the box was reached. Then the geosynthetic was placed through the front slot and on the compacted soil as seen in Figure 3.13. The geosynthetic material was placed in such a way that the maximum contact area was utilized without touching the back or sidewalls. This resulted in approximately $0.1261 \mathrm{~m}^{2}$ of contact area. Finally, the remainder of the soil was placed on top of the geosynthetic in the same manner as the bottom layers. 


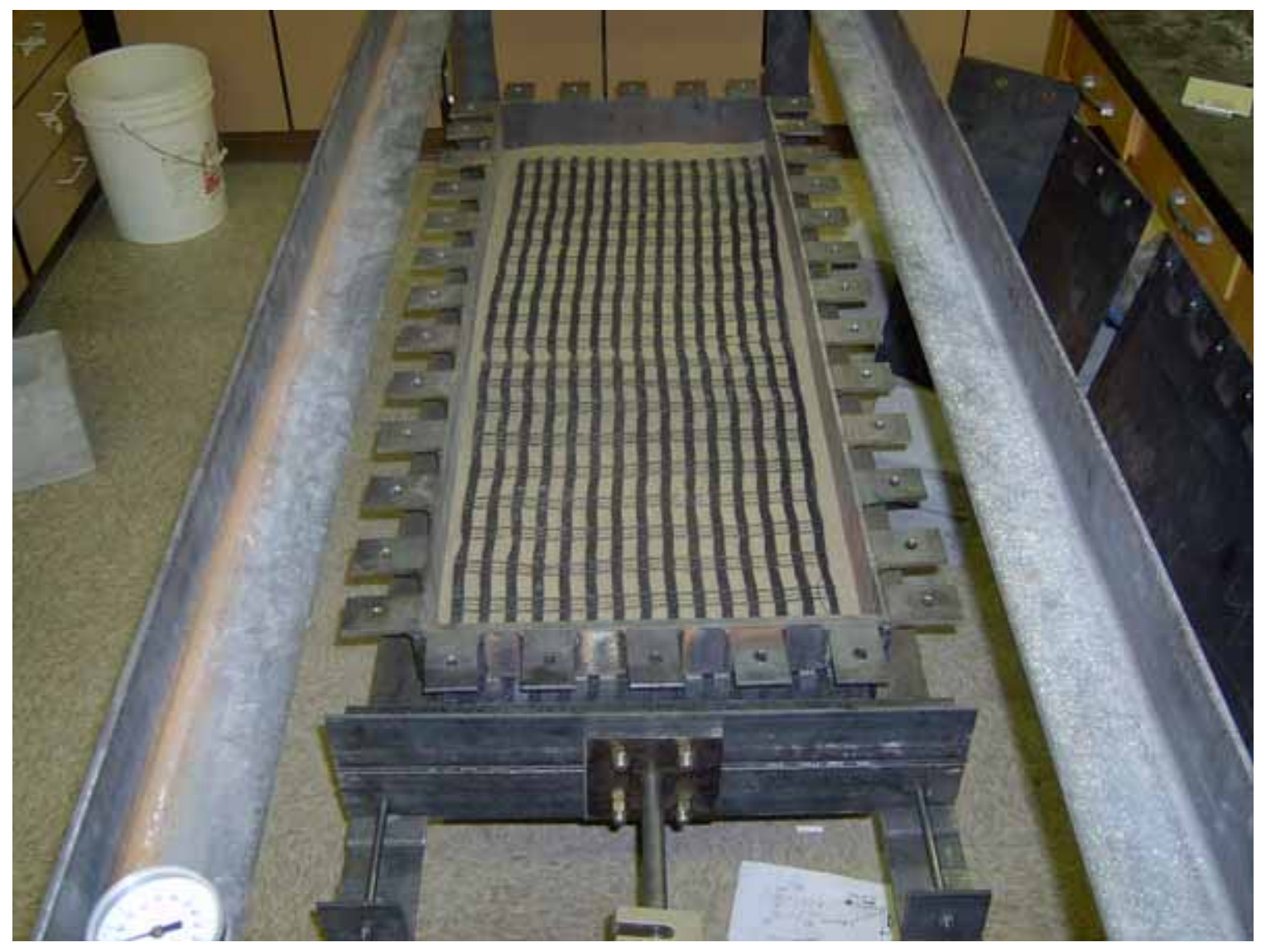

Figure 3.13: Pullout device with geogrid. 


\subsubsection{Procedure for Pullout Testing}

Data collection during pullout tests was done manually. Though a machine controlled constant displacement rate is ideal, as done with pullout box B, it has been shown that displacement rate effects are minimized if the rate of displacement is below 6 $\mathrm{mm} / \mathrm{min}$ [Farrag et al., 1993]. The procedure for pullout testing of both boxes is given below.

1. Obtain and weigh more than enough soil to be used for test.

2. Insert air bag into bottom of box and connect to air hose.

3. Distribute soil in several layers evenly into box, level, and compact each layer. Do this until soil reaches the midpoint of the box.

4. Assemble clamp with geosynthetic attached.

5. Insert geosynthetic into the soil box and connect clamp to pullout shaft.

6. Measure and record distance of geosynthetic to back wall of the soil box at each node.

7. Distribute soil in several layers evenly into top half of box, level, and compact each layer. Do this until soil reaches the marked line on inside of box, which is $1 / 2$ " from the top of the box.

8. Insert top air bag, place lid onto box, and connect airbags to the air pressure regulator.

9. Fasten lid and top stiffeners with bolts.

10. Weigh leftover soil.

11. Record an initial reading and proceed with test.

12. When test is done remove lid, top airbag and carefully remove top half of soil until geosynthetic is showing.

13. Measure and record distance of geosynthetic to back wall of the soil box. 


\subsubsection{Calculations for Pullout Testing}

The calculations for pullout testing are similar to those in direct shear testing. The data obtained from a pullout test includes the pullout force and the displacement. The displacement recorded was the front (end connected to the clamp) displacement of the material, which may not be equal to the rear (end embedded in soil) displacement of the material. This means that the geosynthetic material was stretching during testing. It was not possible to determine if the geosynthetic material was sliding and therefore the contact area was assumed to be constant. The pullout force is divided by twice the original area to calculate the shear stress as seen below. This is done because unlike direct shear tests, pullout tests have two interfaces: one on each side of the geosynthetic [Koener, 1998]. The equation used for shear stress during testing was:

$$
\tau=\frac{F_{p}}{2 A_{o}}
$$

where: $\quad \tau=$ shear stress $(\mathrm{kPa})$

$$
F_{p}=\text { pullout force }(\mathrm{kN})
$$$$
A_{o}=\text { original area of specimen }\left(\mathrm{m}^{2}\right)
$$

When the data was analyzed only the average stresses were considered. This means that the effects of the geogrid apertures were not taken into consideration for geosynthetic materials A and B. The normal stress was simply the pressure that was being applied by the airbag system. These pressures were $34.5 \mathrm{kPa}(5 \mathrm{psi}), 69 \mathrm{kPa}(10 \mathrm{psi})$ and $103.4 \mathrm{kPa}$ (15psi).

The density of soil for each test was found by dividing the mass of the soil used by the volume of soil used. By simply weighing a container of soil before testing and then weighing the same container after the soil has been placed and subtracting the two numbers, the weight of the soil used was found. The volume of the two airbags must be found in order to know the density of soil used. This was done by first filling the pullout box, while empty, with uncompacted soil and measuring the mass of that soil $\left(\mathrm{m}_{\mathrm{s} 1}\right)$. Knowing the volume of the box $\left(\mathrm{V}_{1}\right)$ this density was found $(\mathrm{g})$. Then a deflated airbag 
was placed in the bottom of the pullout box and uncompacted soil was again filled to the top of the box and the mass was measured $\left(\mathrm{m}_{\mathrm{s} 2}\right)$. To find the volume of this soil $\left(\mathrm{V}_{\mathrm{s} 2}\right)$ the mass $\left(\mathrm{m}_{\mathrm{s} 2}\right)$ was divided by $\mathrm{g}$. The difference in the two volumes $\left(\mathrm{V}_{\mathrm{s} 1}-\mathrm{V}_{\mathrm{s} 2}\right)$ resulted in the volume of the airbag. These calculations are shown in Table 3.2. By using this volume and the mass of the soil within the box, the density of soil used in each test was calculated.

Table 3.2: Volume of one airbag used in pullout test.

\begin{tabular}{|c|c|c|c|}
\hline & \multicolumn{3}{|c|}{ VOLUME OF AIRBAG } \\
\hline \multirow{3}{*}{ 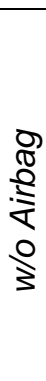 } & $\begin{array}{l}\text { Mass of Soil }(\mathrm{kg}) \text {, } \\
\mathrm{m}_{\mathrm{s} 1}\end{array}$ & $=$ & 32.535 \\
\hline & $\begin{array}{l}\text { Volume of Soil } \\
\qquad\left(\mathrm{m}^{3}\right), \mathrm{V}_{\mathrm{s} 1}\end{array}$ & $=$ & 0.0212 \\
\hline & $\begin{array}{c}\text { Density }\left(\mathrm{kg} / \mathrm{m}^{3}\right) \text {, } \\
\mathrm{g}\end{array}$ & $=$ & 1531.95 \\
\hline \multirow{3}{*}{ 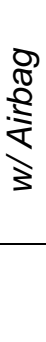 } & $\begin{array}{c}\text { Mass of Soil }(\mathrm{kg}), \\
\mathrm{m}_{\mathrm{s} 2}\end{array}$ & $=$ & 30.518 \\
\hline & $\begin{array}{l}\text { Volume of Soil } \\
\qquad\left(\mathrm{m}^{3}\right), \mathrm{V}_{\mathrm{s} 2}\end{array}$ & $=m_{\mathrm{s} 2} / g=$ & 0.0199 \\
\hline & $\begin{array}{c}\text { Volume of Airbag } \\
\qquad\left(\mathrm{m}^{3}\right)\end{array}$ & $=\mathrm{V}_{\mathrm{s} 1}-\mathrm{V}_{\mathrm{s} 2}=$ & 0.0013 \\
\hline
\end{tabular}

Shear stress values at failure were averaged and plotted against the average of the two corresponding normal stress values at failure. These stress values were plotted to create the failure envelope. Once this graph was created a trend line was placed to obtain the angle of friction and effective cohesion. The effective cohesion is equal to the $y$ intercept of the trend line. The angle of friction was calculated using Equation 3.5 as shown for direct shear tests in Section 3.1.4. 


\section{CHAPTER 4: RESULTS AND DISCUSSION}

\subsection{Direct Shear Test Results and Discussion}

This section shows and discusses the results from direct shear testing. Three different soils were tested: sand, silt and clay. Six different interfaces were tested using sand. The first was a sand-sand interface at zero percent water content. Sand-sand interface was also tested at ten and fifteen percent water contents. The properties of the sand used in all direct shear tests can be found in section 3.1.1. The fourth interface tested was a geogrid-sand interface. This geogrid is referred to as material A. The fifth interface tested was also a geogrid-sand interface. This geogrid is referred to as material B. The sixth and final interface tested with sand was a geotextile-sand interface. This geotextile was referred to as material C. All geosynthetic properties can be found in Table 3.1. Silt-silt interfaces and clay-clay interfaces were also tested using zero, ten and fifteen percent water content. Grain size distributions of these silt and clay materials can be found in Figures 3.2 and 3.3.

A minimum of three normal stresses were used. These are $35.3 \mathrm{kPa}$ (5.1 psi), 69.6 $\mathrm{kPa}(10.1 \mathrm{psi})$ and $103.9 \mathrm{kPa}$ (15.1 psi). Two tests were run for each specimen configuration to ensure reliability and a new geosynthetic sample was used for each test to avoid any fatigue in the specimen. The results and discussions are presented in this section.

Figures 4.1, 4.2 and 4.3 show the direct shear stress-strain relationship for sandsand interface. Figure 4.4 illustrates the failure envelope for this interface. An angle of friction equal to 26.7 degrees and an effective cohesion of zero were recorded. 
DIRECT SHEAR TEST RESULTS

Sand-Sand Interface, $0 \%$ water content, $S_{n}=35.3 \mathrm{kPa}$

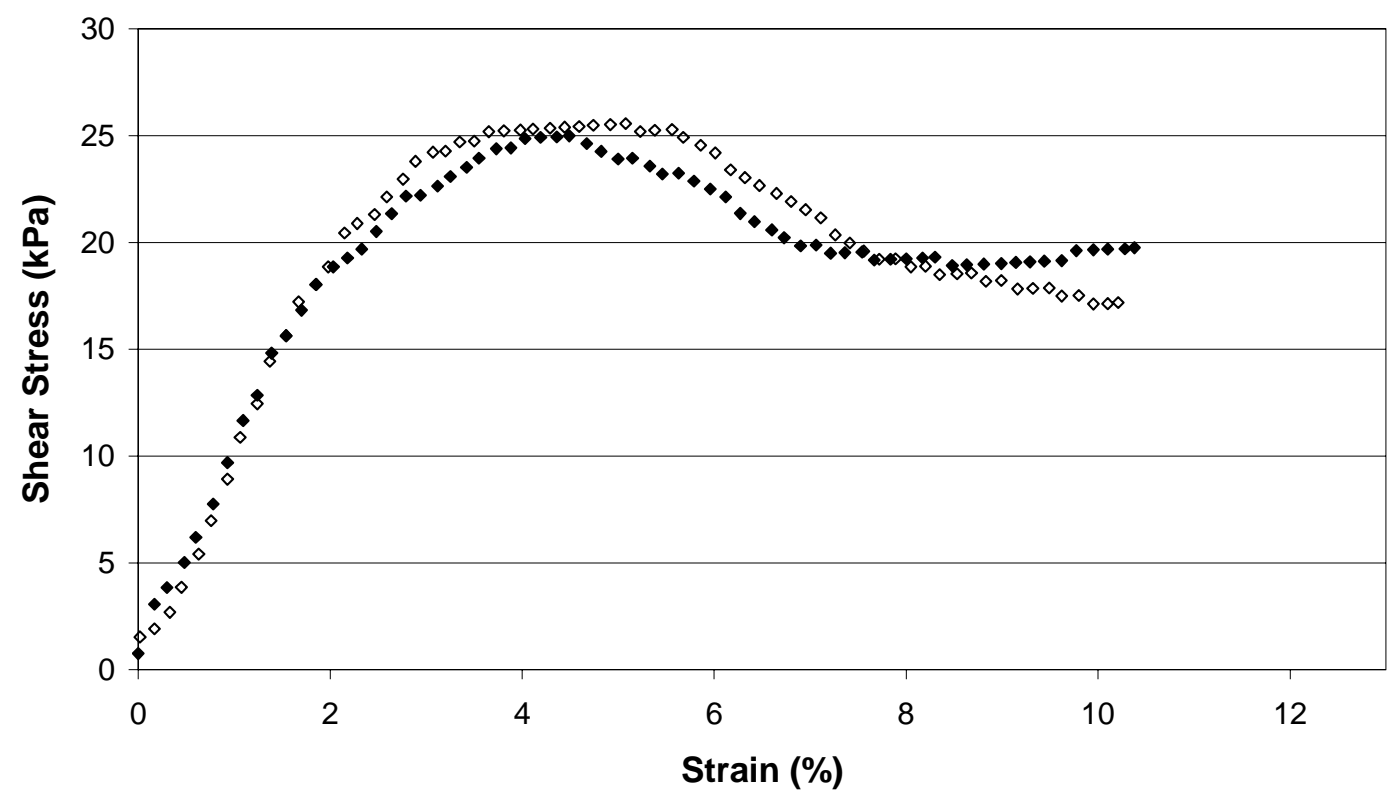

Figure 4.1: Direct shear test results for sand-sand interface at $S_{n}=35.3 \mathrm{kPa}$. 
DIRECT SHEAR TEST RESULTS

Sand-Sand Interface, $0 \%$ water content, $S_{n}=69.6 \mathrm{kPa}$

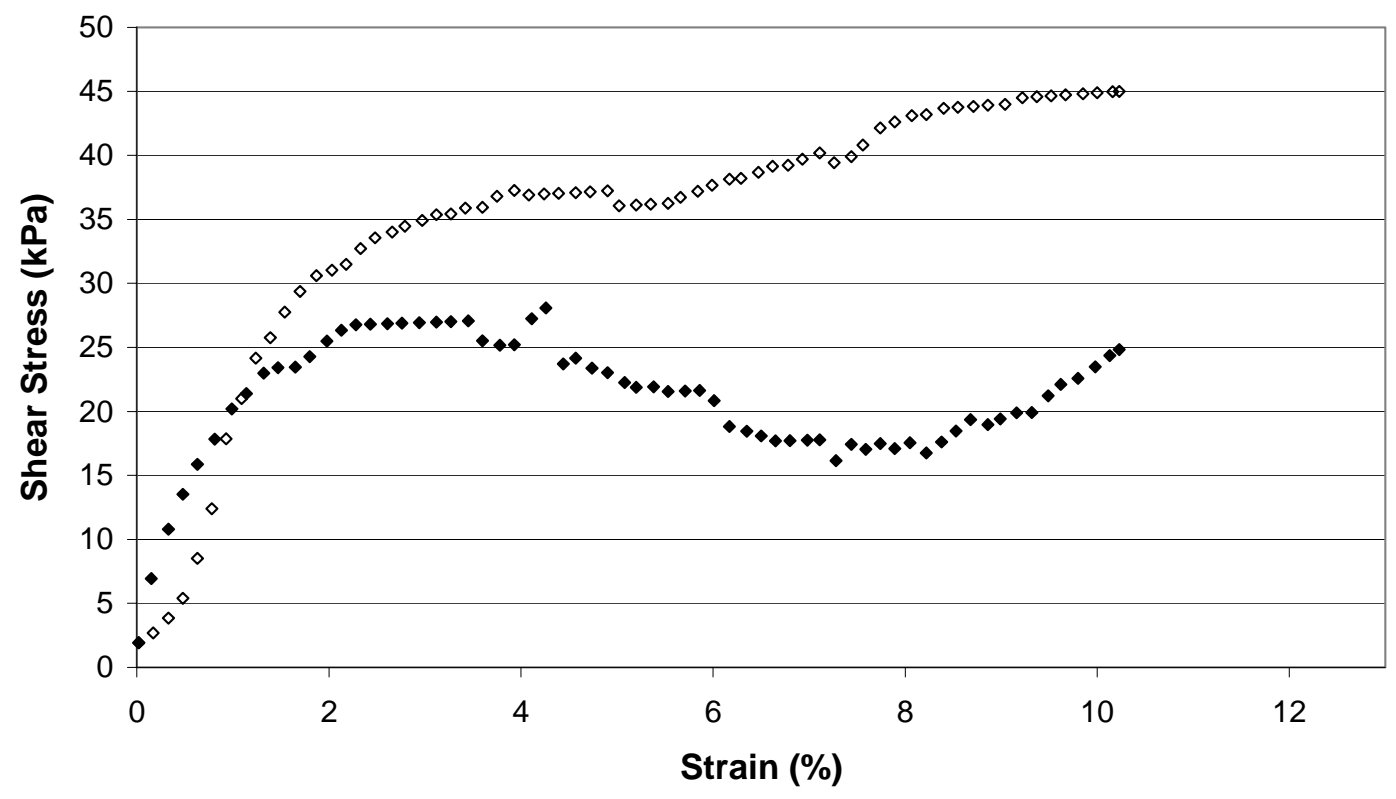

Figure 4.2: Direct shear test results for sand-sand interface, $S_{n}=69.6 \mathrm{kPa}$. 


\section{DIRECT SHEAR TEST RESULTS}

Sand-Sand Interface, $0 \%$ water content, $S_{n}=103.9 \mathrm{kPa}$

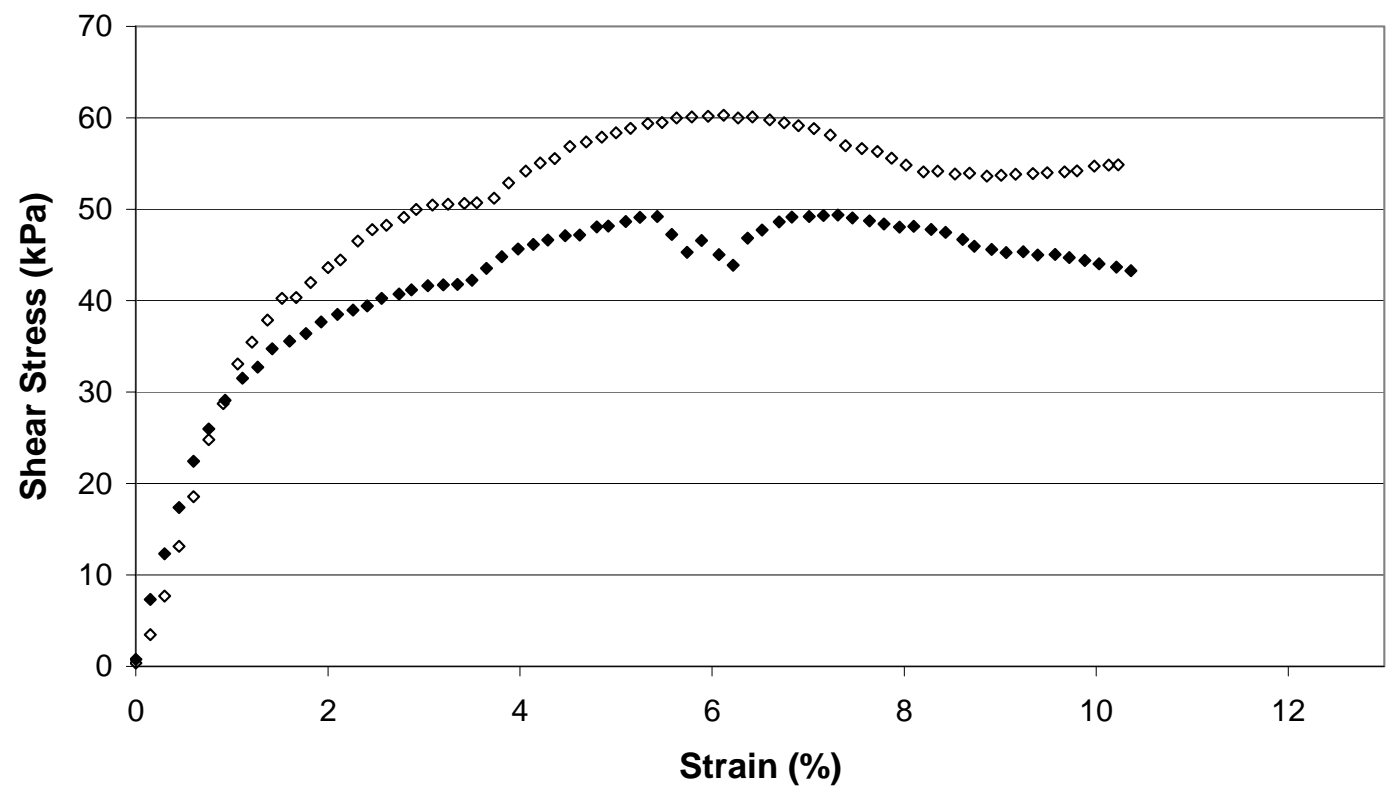

Figure 4.3: Direct shear test results for sand-sand interface, $S_{n}=103.9 \mathrm{kPa}$. 
DIRECT SHEAR FAILURE ENVELOPE

Sand-Sand Interface, $0 \%$ water content

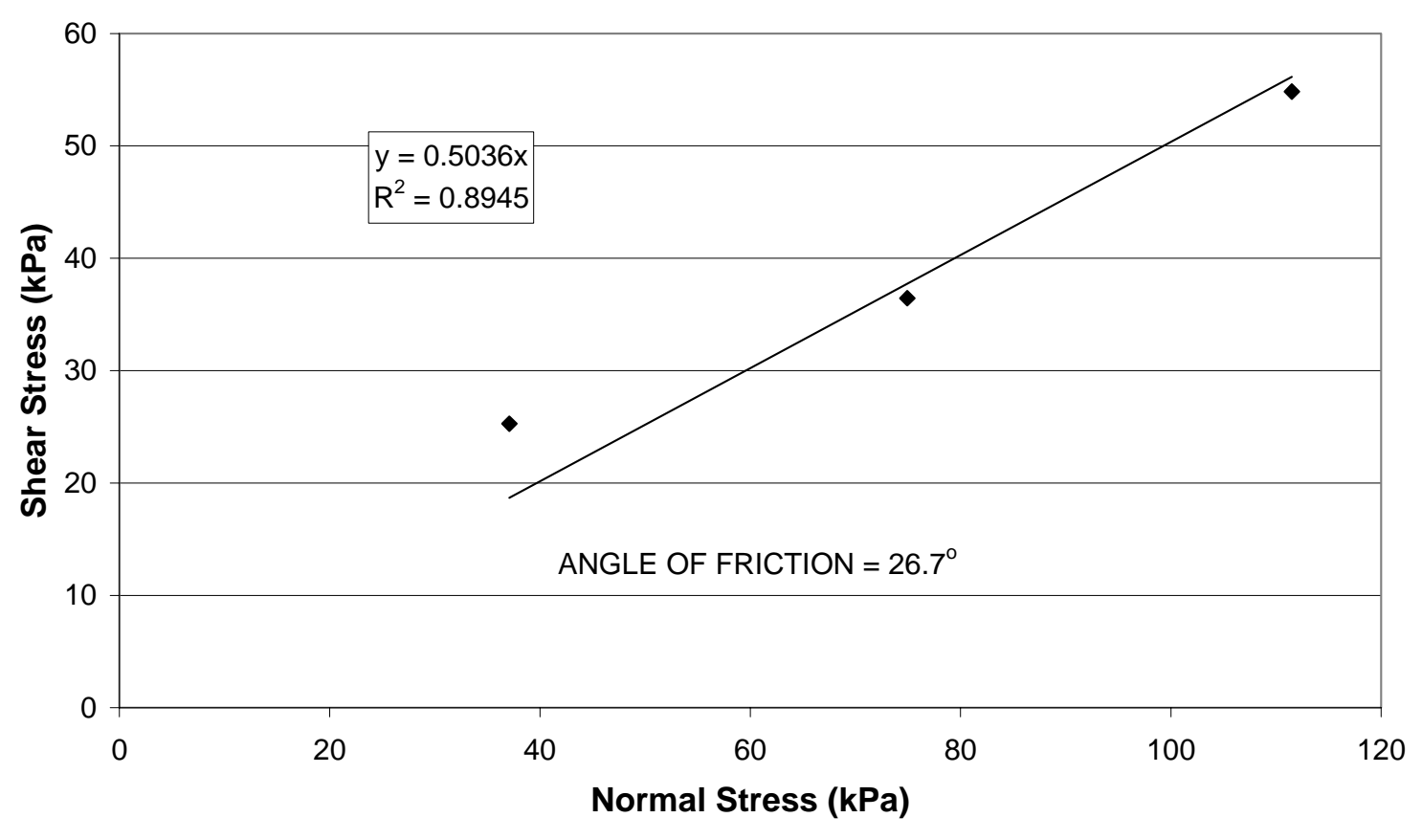

Figure 4.4: Direct shear failure envelope, sand - sand interface. 
Figures 4.5, 4.6 and 4.7 show the stress-strain relationship for material A-sand interface. Figure 4.8 shows the failure envelope for this interface. This failure envelope presents an angle of friction of 27 degrees and an effective cohesion of zero.

\section{DIRECT SHEAR TEST RESULTS \\ Material A - Sand Interface, $S_{n}=35.3 \mathrm{kPa}$}

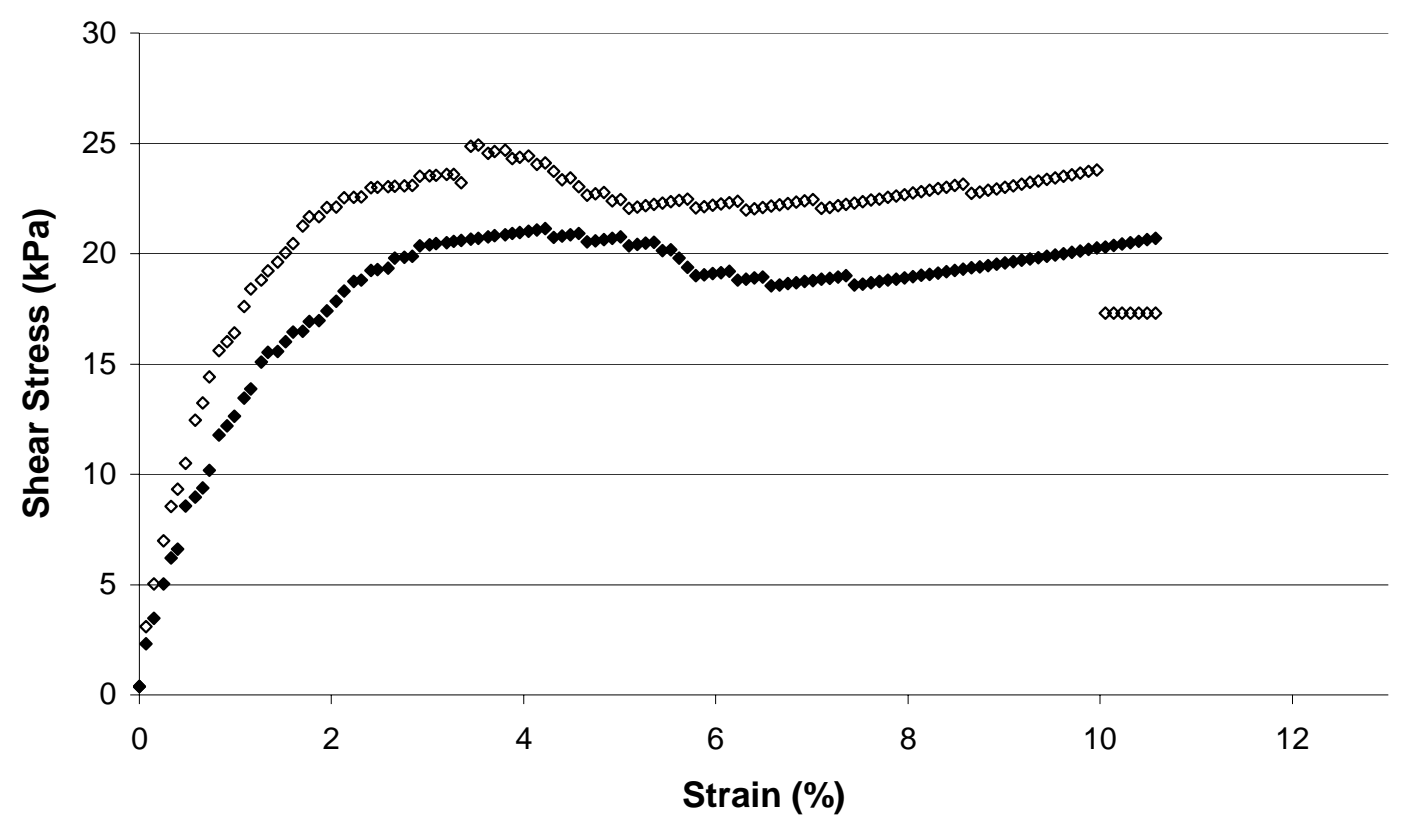

Figure 4.5: Direct shear test results for material A-sand interface at $S_{n}=35.3 \mathrm{kPa}$. 
DIRECT SHEAR TEST RESULTS

Material A - Sand Interface, $S_{n}=69.6 \mathrm{kPa}$

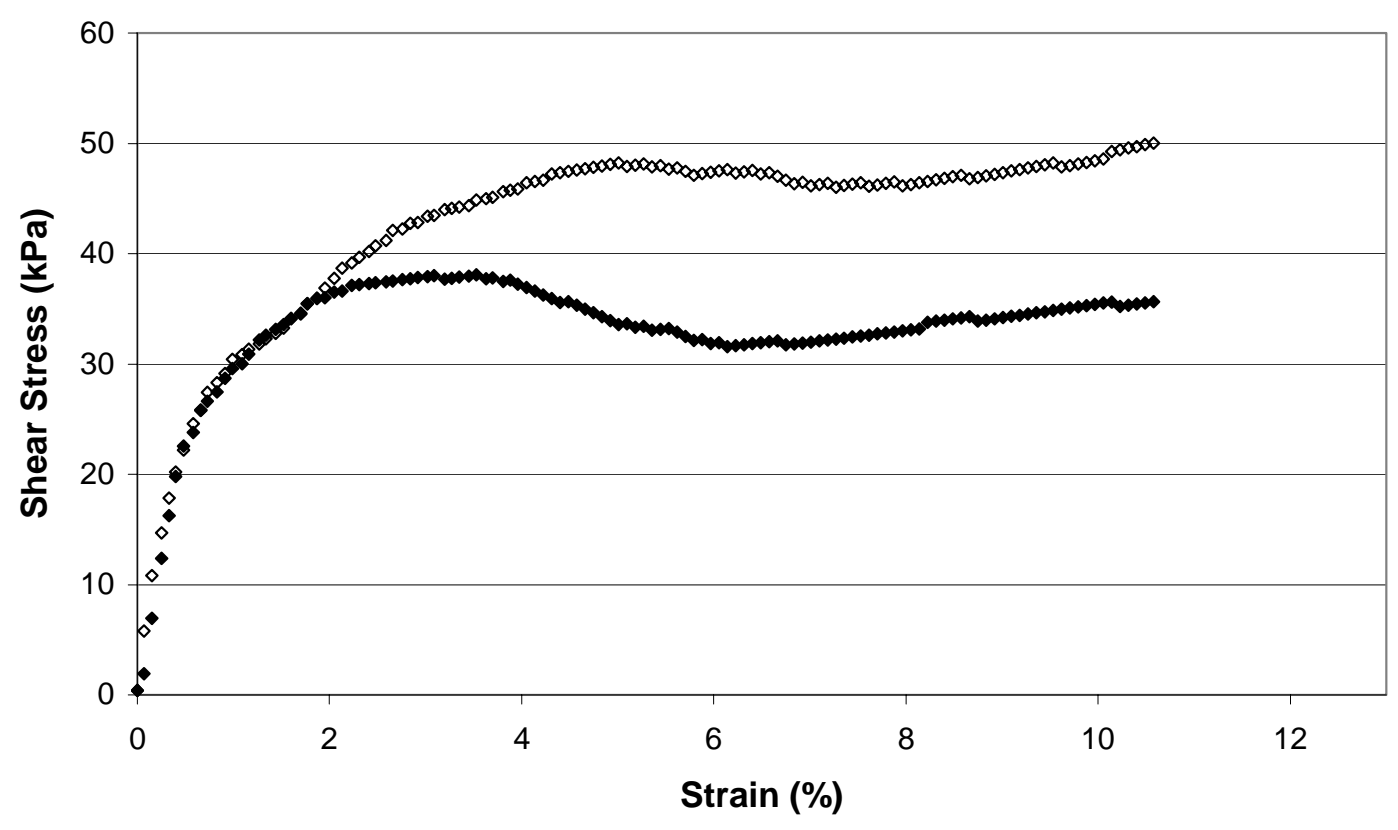

Figure 4.6: Direct shear test results for material A-sand interface at $S_{n}=69.6 \mathrm{kPa}$. 


\section{DIRECT SHEAR TEST RESULTS}

Material A - Sand Interface, $S_{n}=103.9 \mathrm{kPa}$

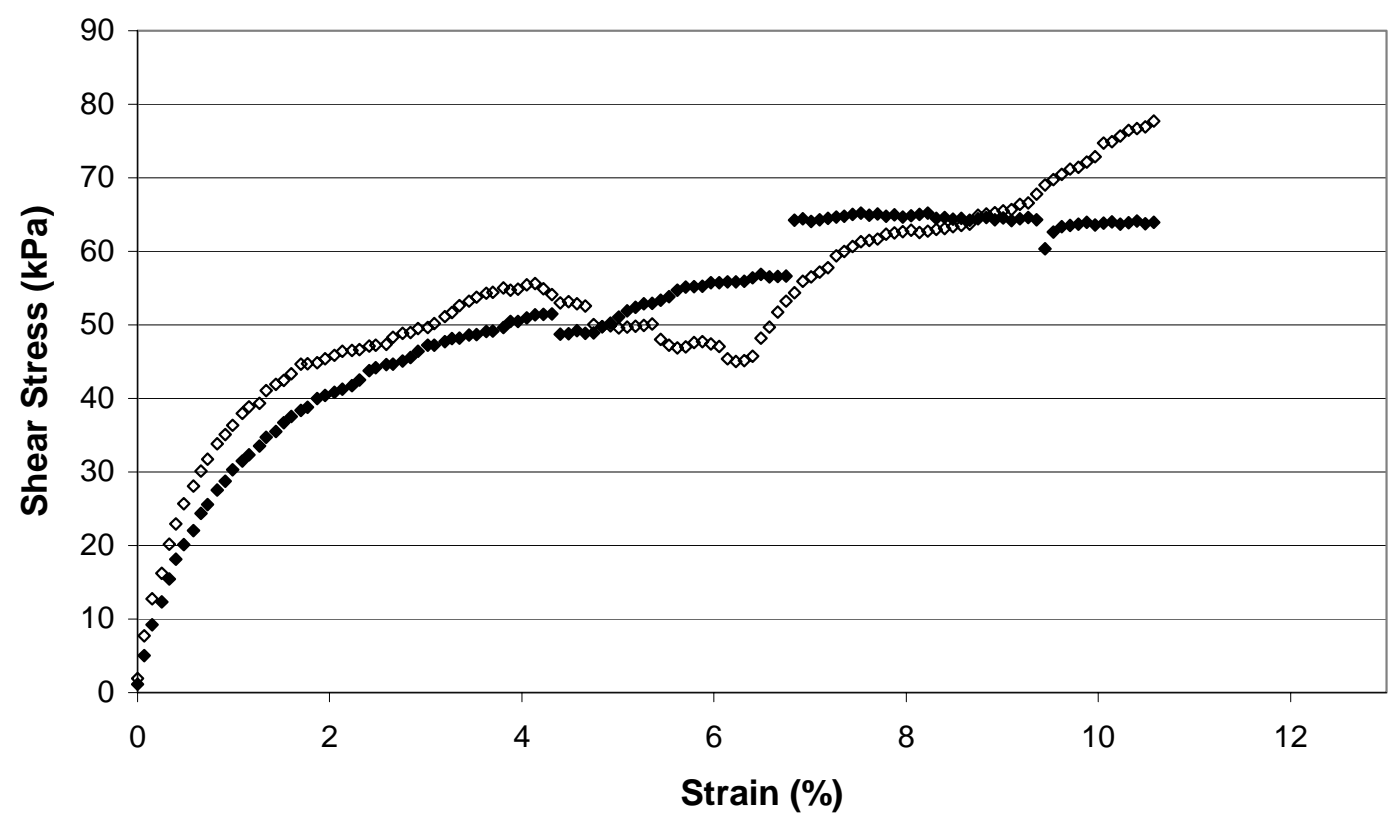

Figure 4.7: Direct shear test results for material A-sand interface at $S_{n}=103.9 \mathrm{kPa}$. 


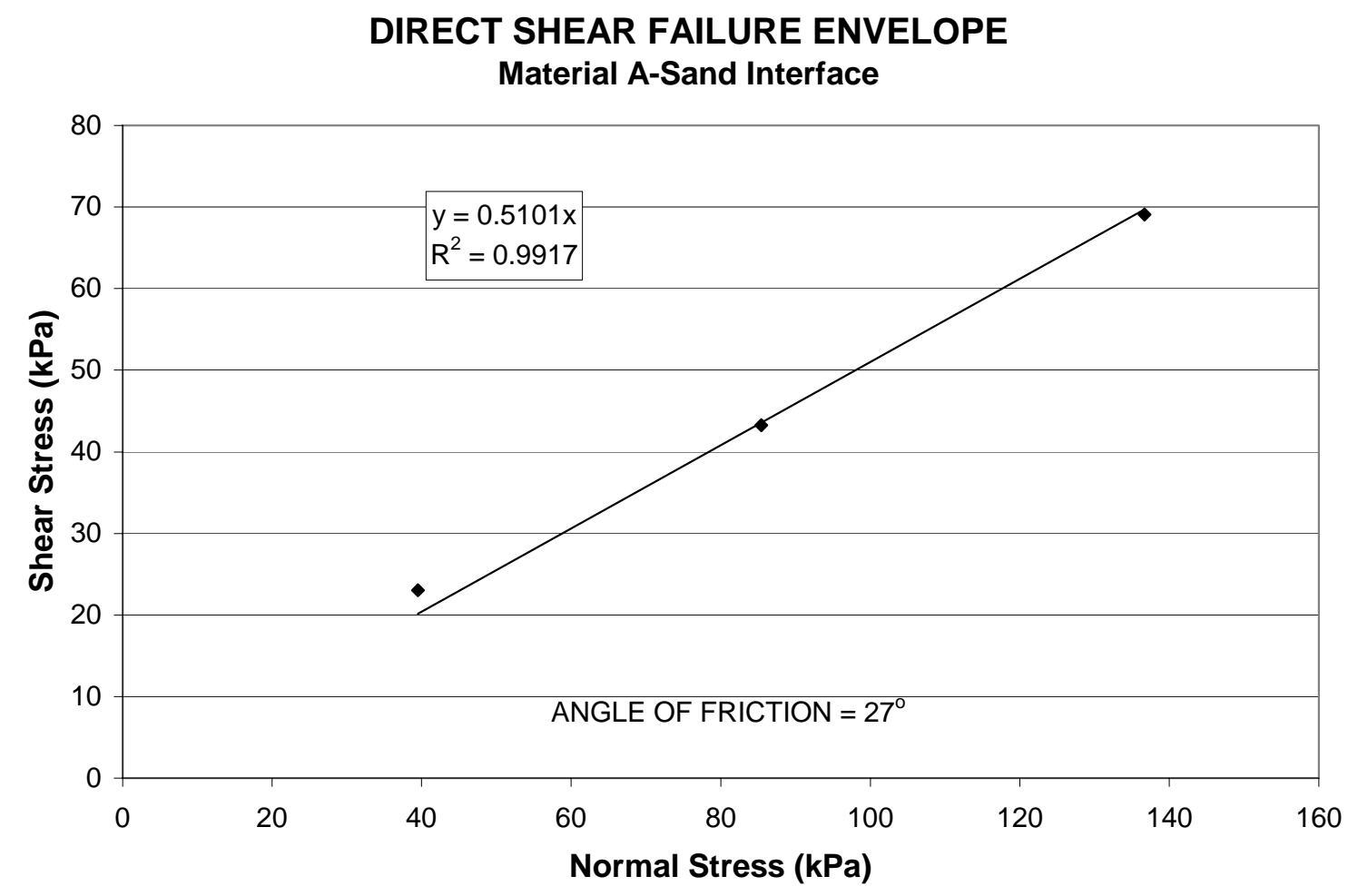

Figure 4.8: Direct shear failure envelope for material A-sand interface. 
In the following three figures, Figure 4.9, 4.10 and 4.11, the direct shear stressstrain relationship for material B-sand is presented. An angle of friction equal to 31.5 degrees is shown in Figure 4.12. This figure illustrates the failure envelope for the interface and shows an effective cohesion of zero.

DIRECT SHEAR RESULTS

Material B - Sand Interface, $S_{n}=35.3 \mathrm{kPa}$

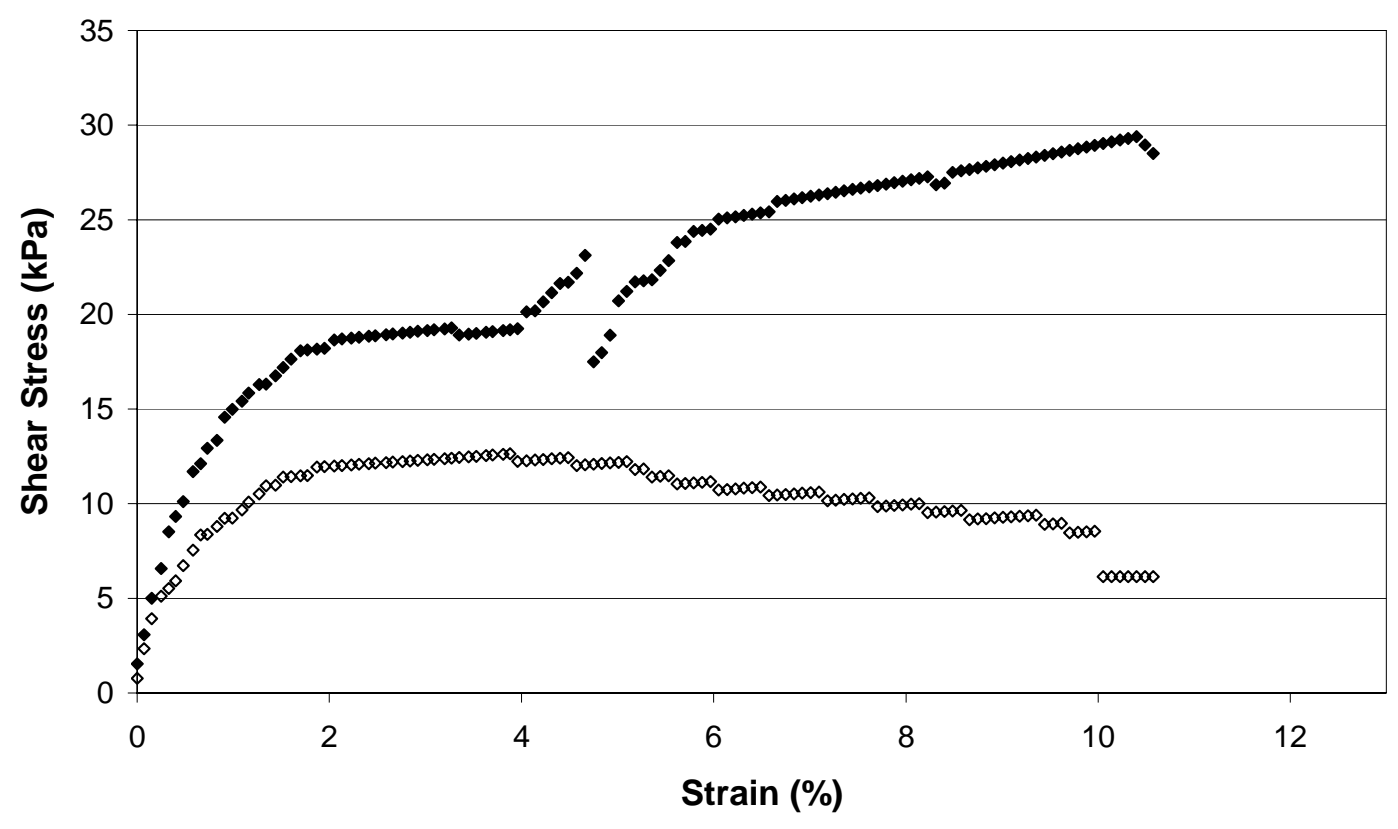

Figure 4.9: Direct shear test results for material B-sand interface, $S_{n}=35.3 \mathrm{kPa}$. 
DIRECT SHEAR RESULTS

Material B - Sand Interface, $S_{n}=69.6 \mathrm{kPa}$

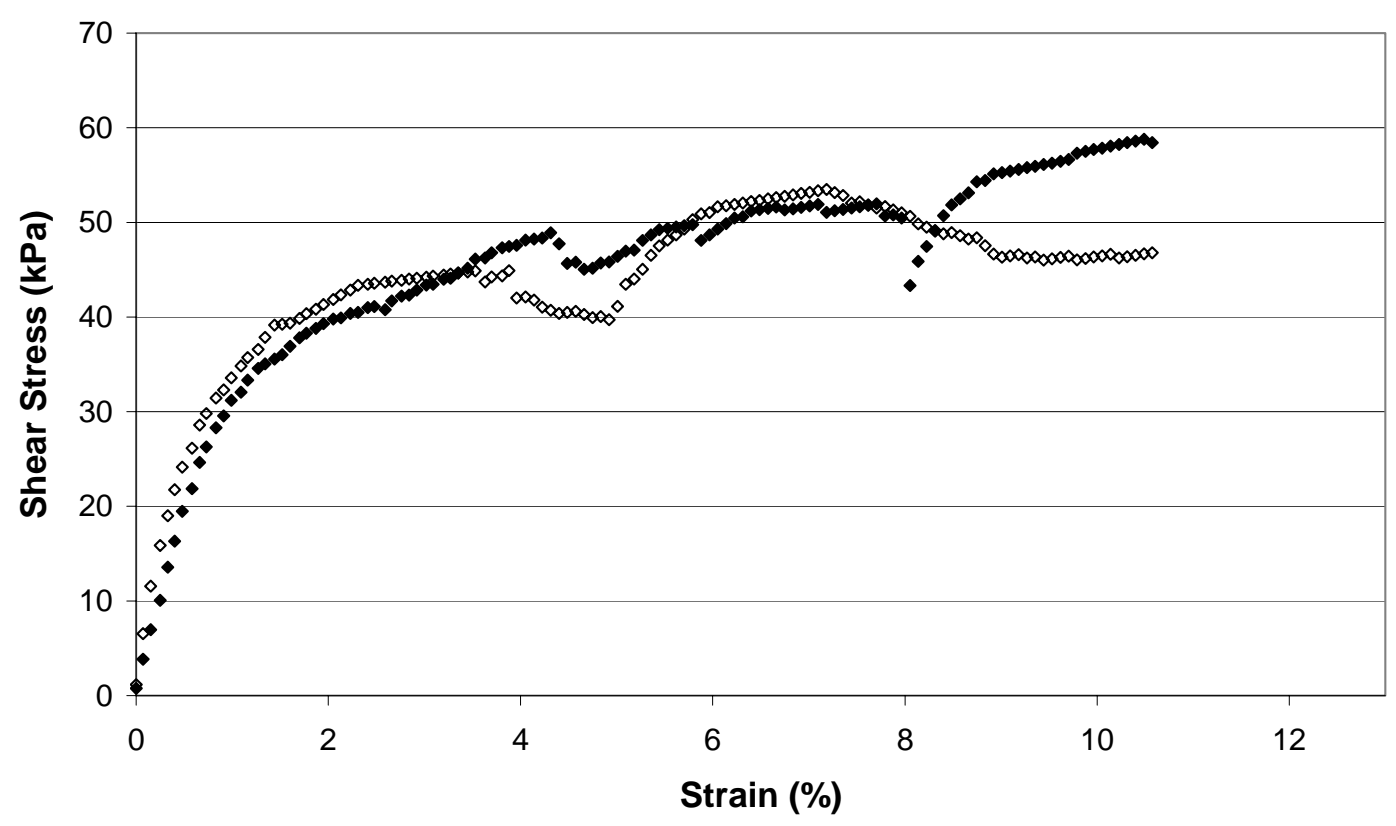

Figure 4.10: Direct shear test results for material B-sand interface, $S_{n}=69.6 \mathrm{kPa}$. 
DIRECT SHEAR RESULTS

Material B - Sand Interface, $S_{n}=103.9 \mathrm{kPa}$

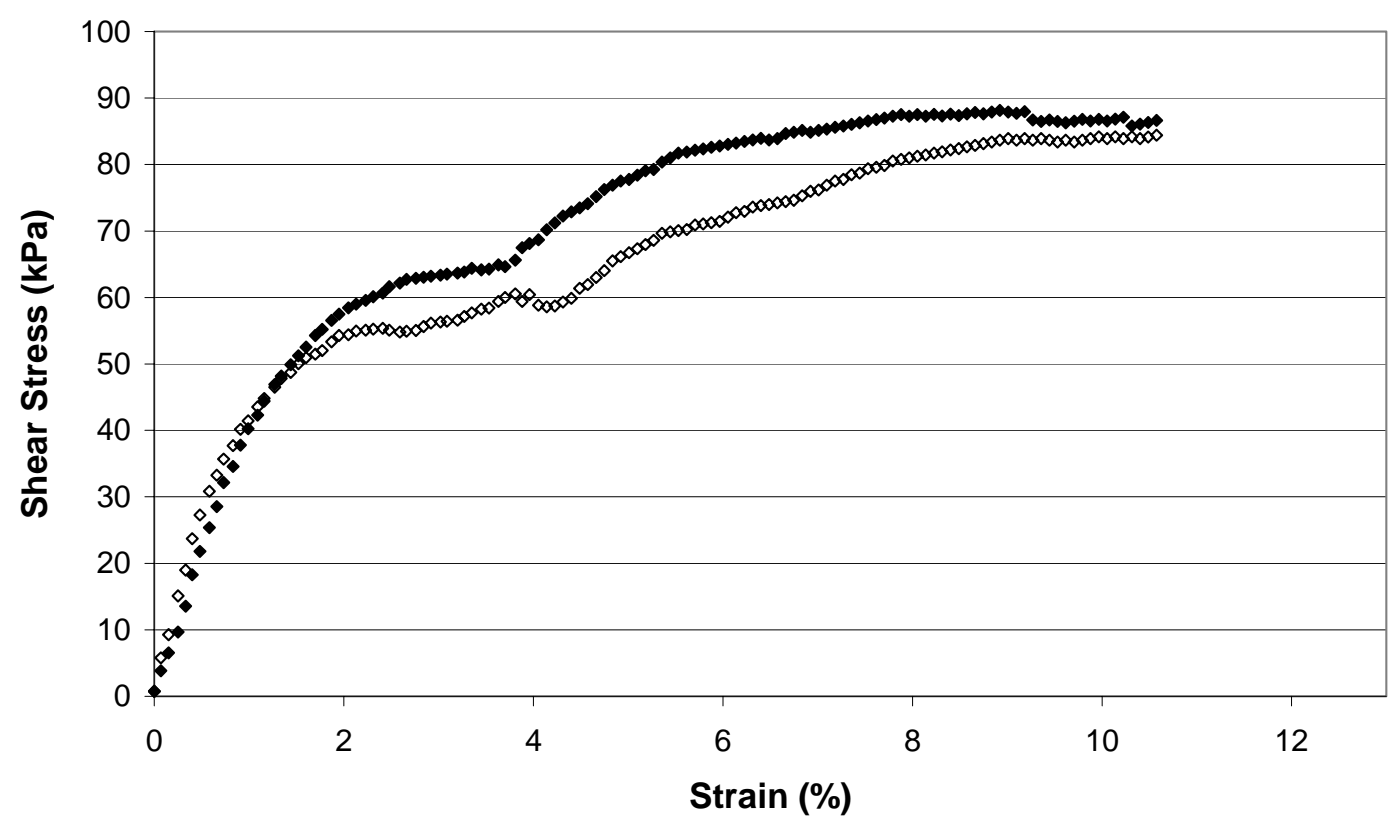

Figure 4.11: Direct shear test results for material B-sand interface, $S_{n}=103.9 \mathrm{kPa}$. 


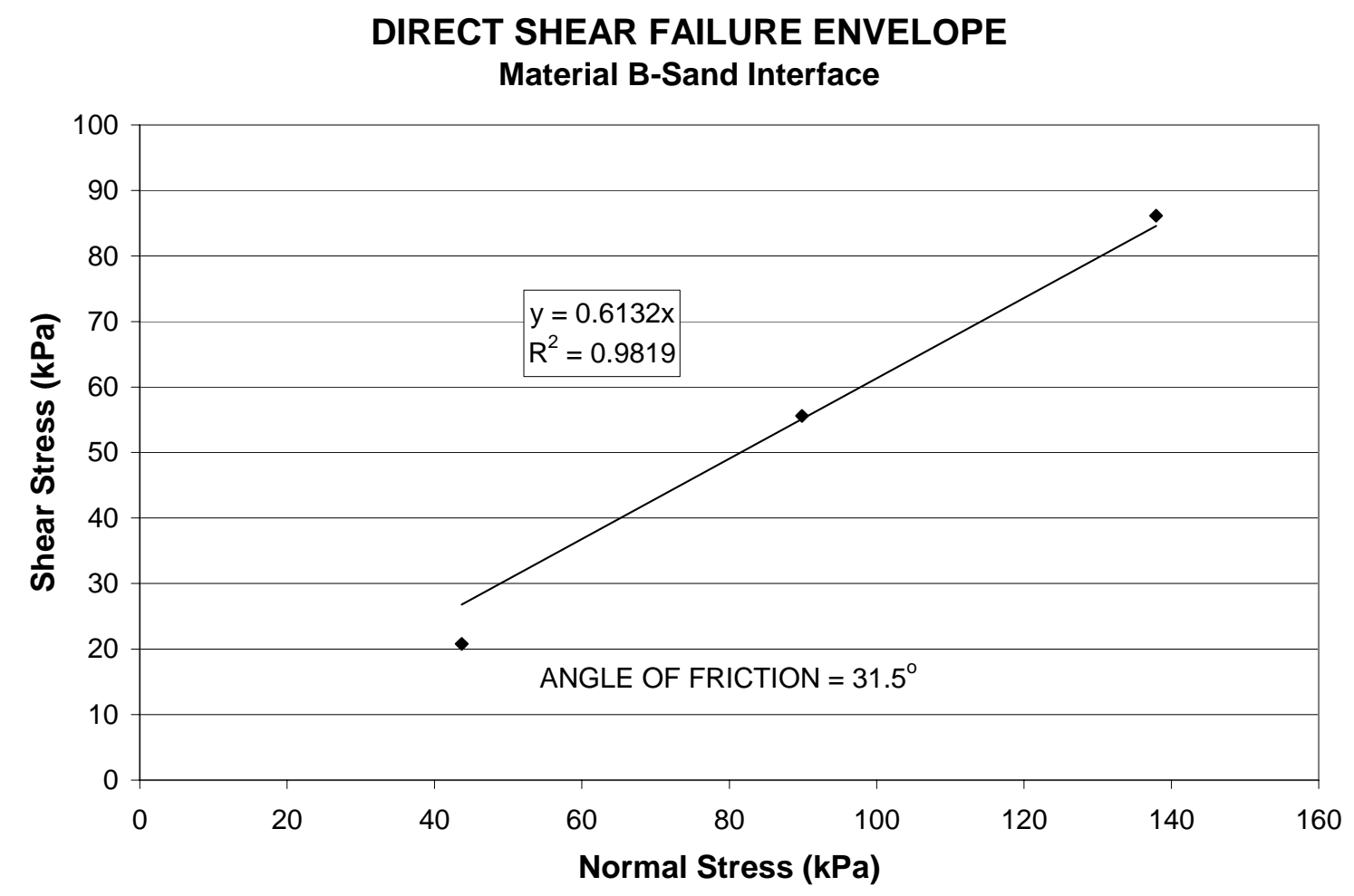

Figure 4.12: Direct shear failure envelope, material B - sand interface. 
Figures 4.13, 4.14 and 4.15 show the direct shear stress-strain relationship for material C-sand interface. Figure 4.16 illustrates the failure envelope for this interface. An angle of friction equal to 29.5 degrees and an effective cohesion equal to zero were recorded. This angle of friction is also similar to the angle of friction reported for the sand-sand interface.

Material C - Sand Interface, $S_{n}=35.3 \mathrm{kPa}$

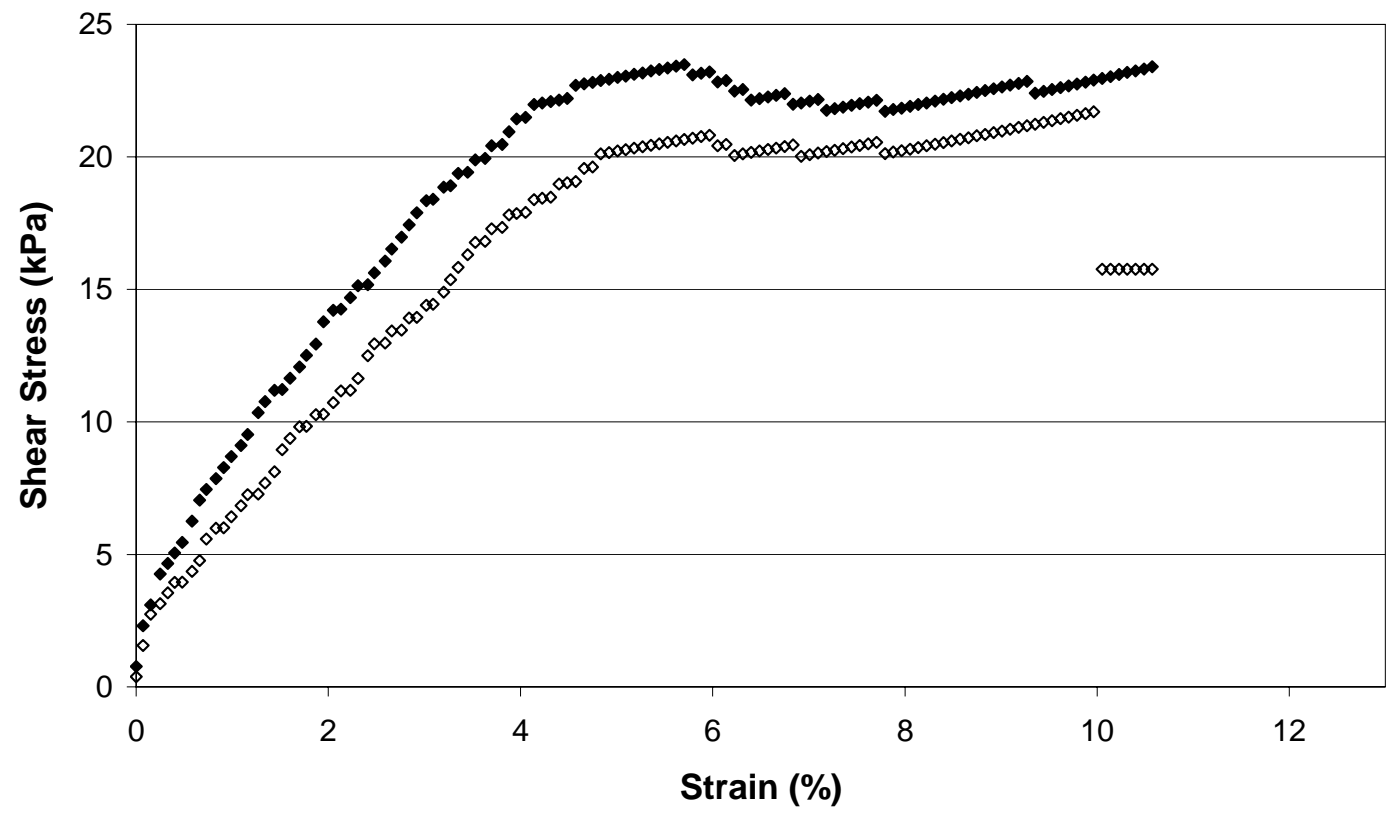

Figure 4.13: Direct shear test results, material C-sand interface, $S_{n}=35.3 \mathrm{kPa}$. 
DIRECT SHEAR RESULTS

Material C - Sand Interface, $S_{n}=69.6 \mathrm{kPa}$

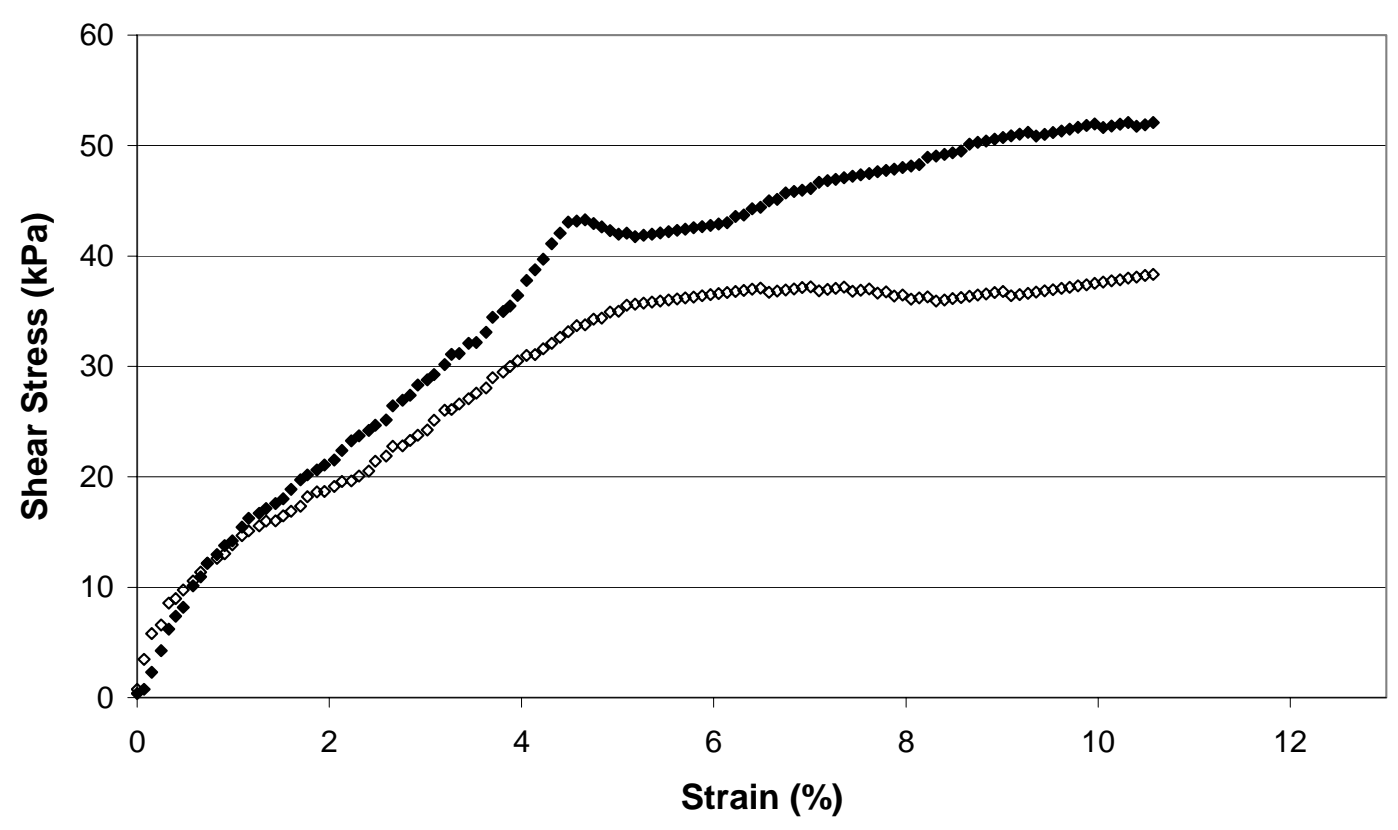

Figure 4.14: Direct shear test results, material C-sand interface, $S_{n}=69.6 \mathrm{kPa}$. 
DIRECT SHEAR RESULTS

Material C - Sand Interface, $S_{n}=103.9 \mathrm{kPa}$

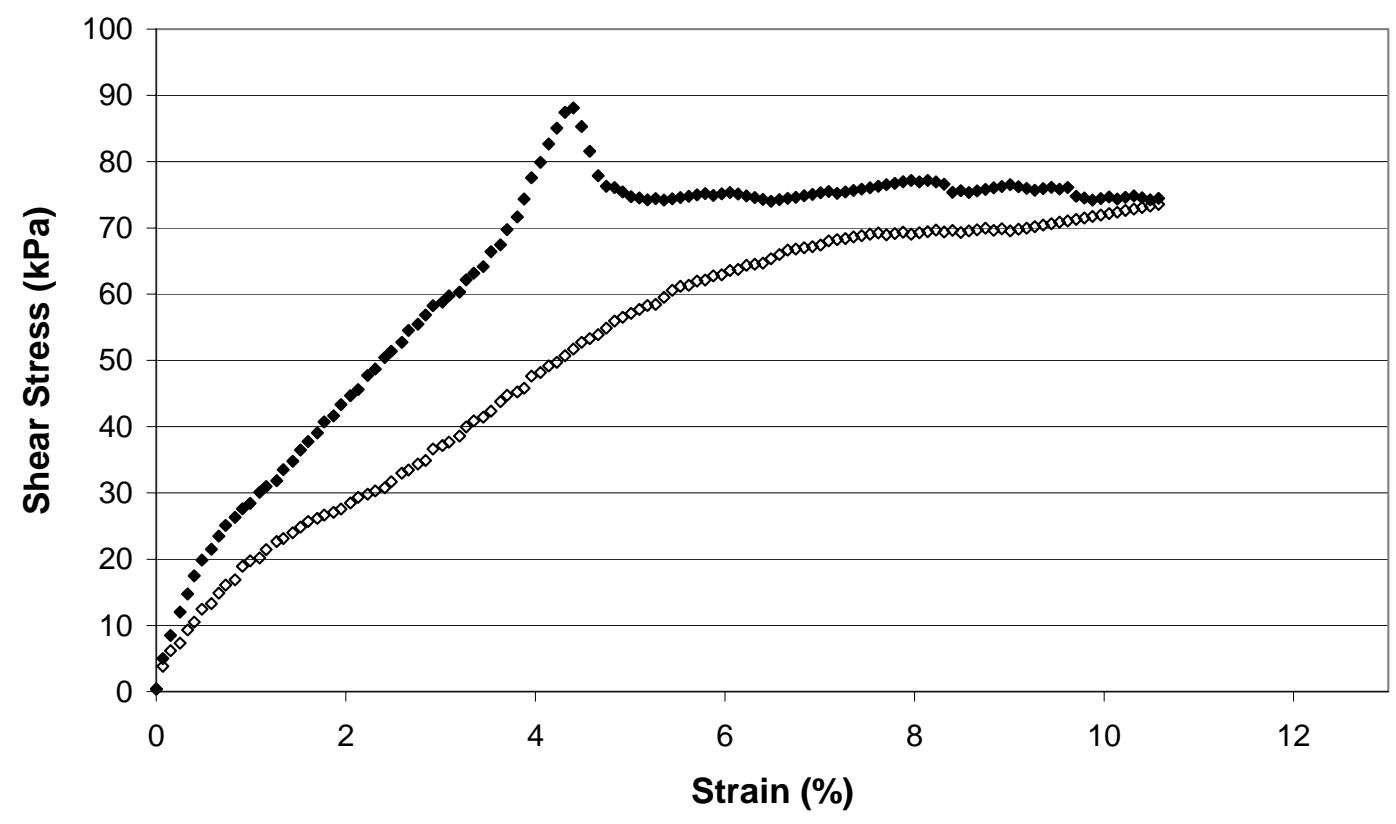

Figure 4.15: Direct shear test results, material C-sand interface, $S_{n}=103.9 \mathrm{kPa}$. 


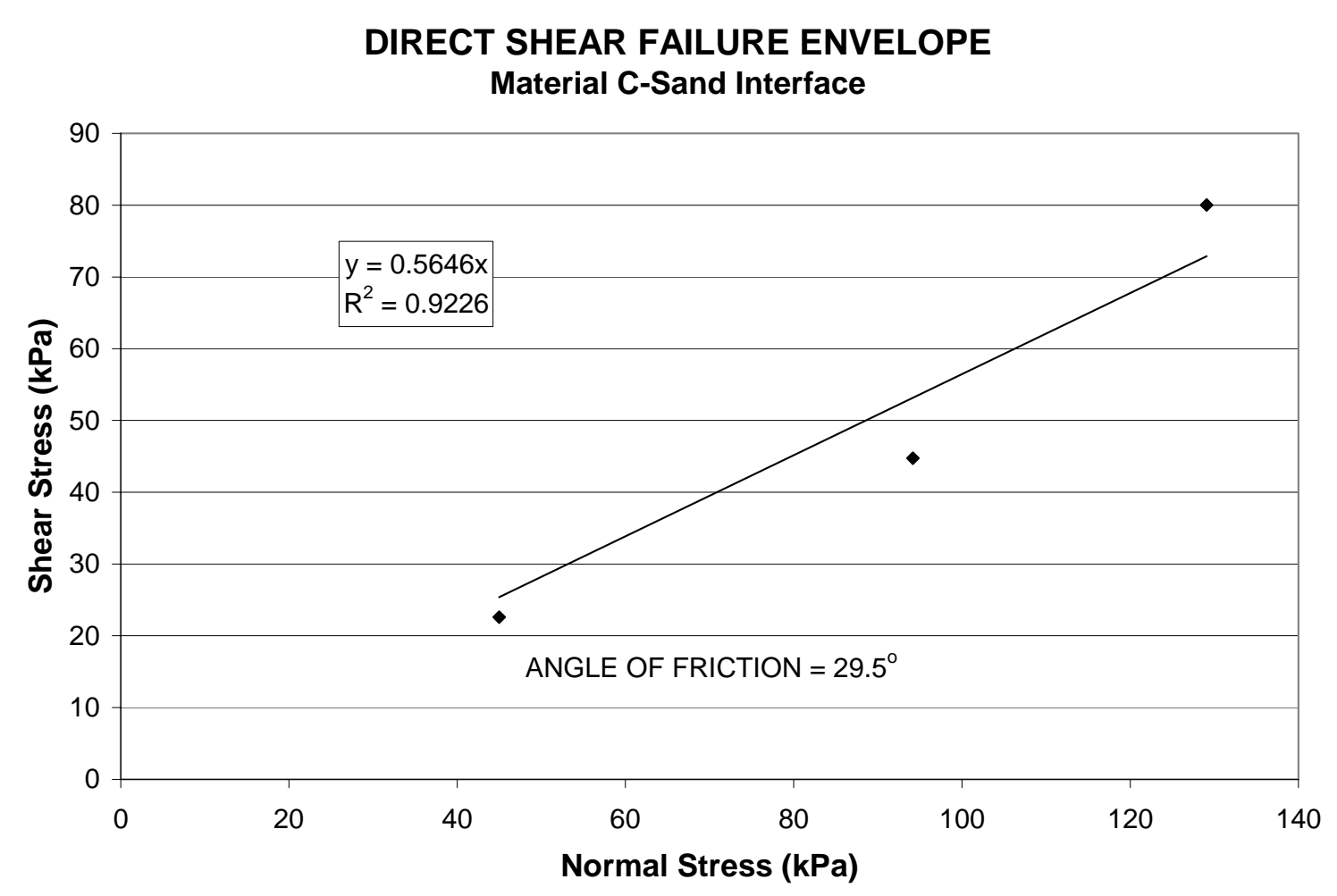

Figure 4.16: Direct shear failure envelope, material C - sand interface. 
Figures 4.17, 4.18 and 4.19 show the direct shear stress-strain relationship for sand-sand interface. Figure 4.20 illustrates the failure envelope for this interface. An angle of friction equal to 24.1 degrees and an effective cohesion of $5.5 \mathrm{kPa}$ were recorded.

\section{DIRECT SHEAR TEST RESULTS \\ Sand-Sand Interface, $10 \%$ water content, $S_{n}=35.3 \mathrm{kPa}$}

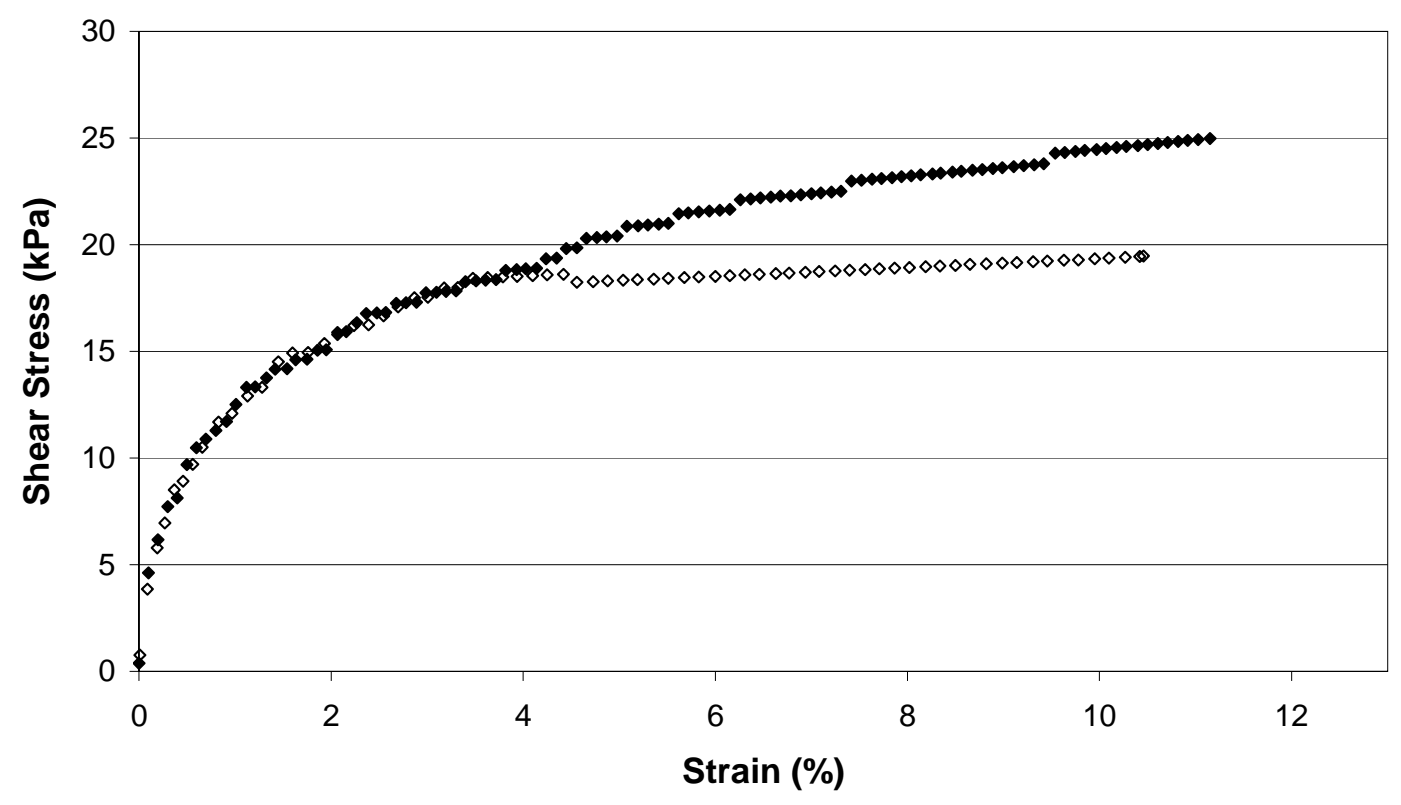

Figure 4.17: Direct shear test results for sand-sand interface at $\sigma_{\mathrm{n}}=35.3 \mathrm{kPa}$ with $10 \%$ water content. 
DIRECT SHEAR TEST RESULTS

Sand-Sand Interface, $10 \%$ water content, $S_{n}=69.6 \mathrm{kPa}$

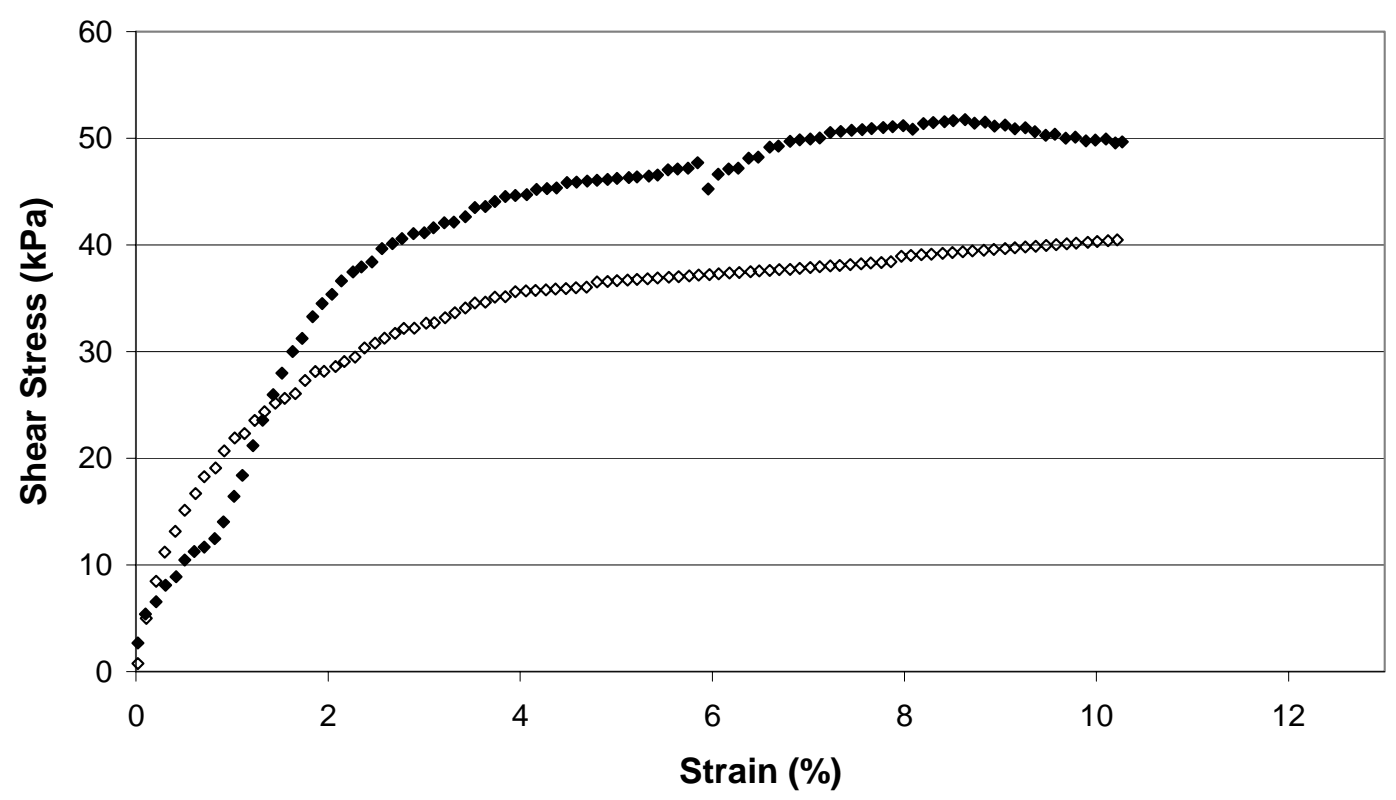

Figure 4.18: Direct shear test results for sand-sand interface at $\sigma_{\mathrm{n}}=69.6 \mathrm{kPa}$ with $10 \%$ water content. 
DIRECT SHEAR TEST RESULTS

Sand-Sand Interface, $10 \%$ water content, $S_{n}=103.9 \mathrm{kPa}$

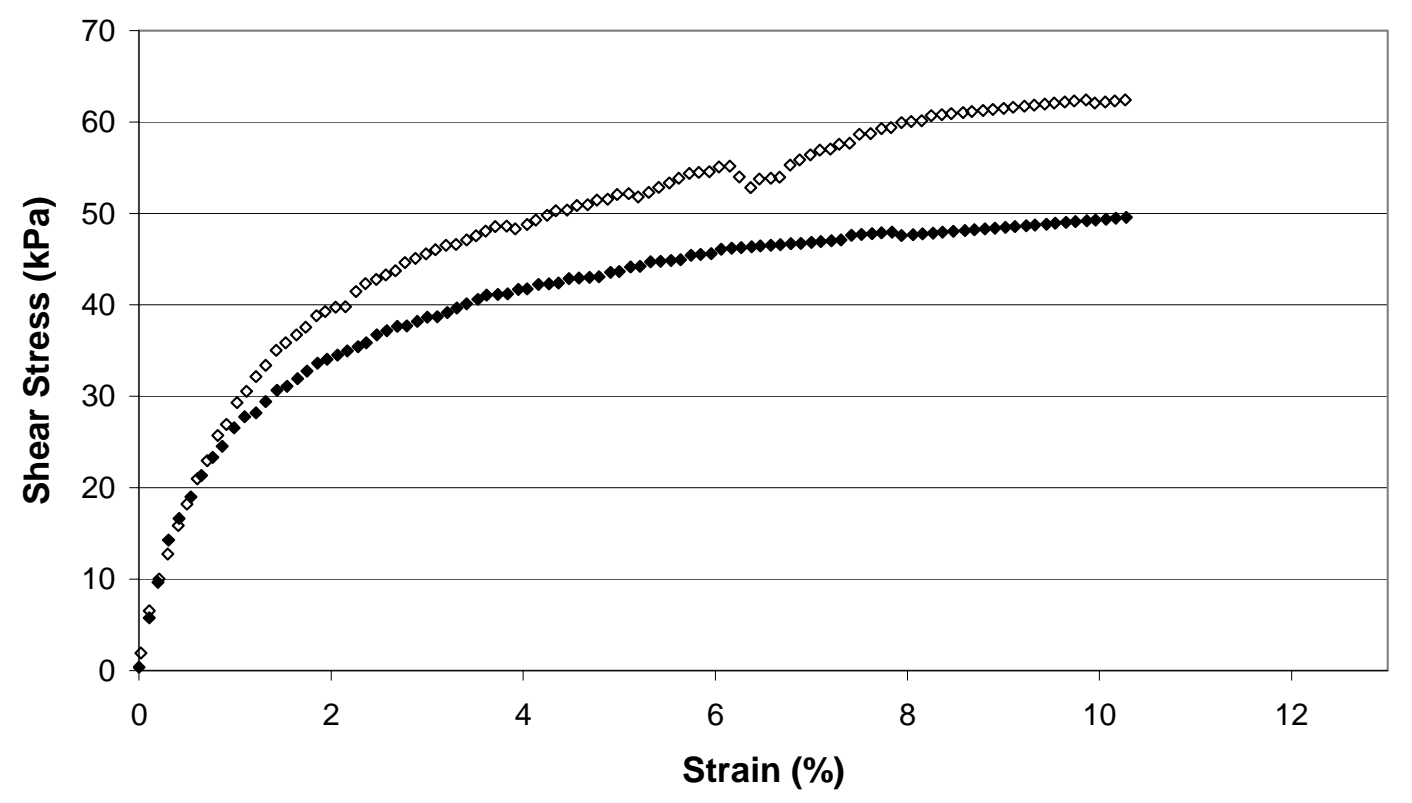

Figure 4.19: Direct shear test results for sand-sand interface at $\sigma_{\mathrm{n}}=103.9 \mathrm{kPa}$ with $10 \%$ water content. 
DIRECT SHEAR FAILURE ENVELOPE

Sand-Sand Interface, $10 \%$ water content

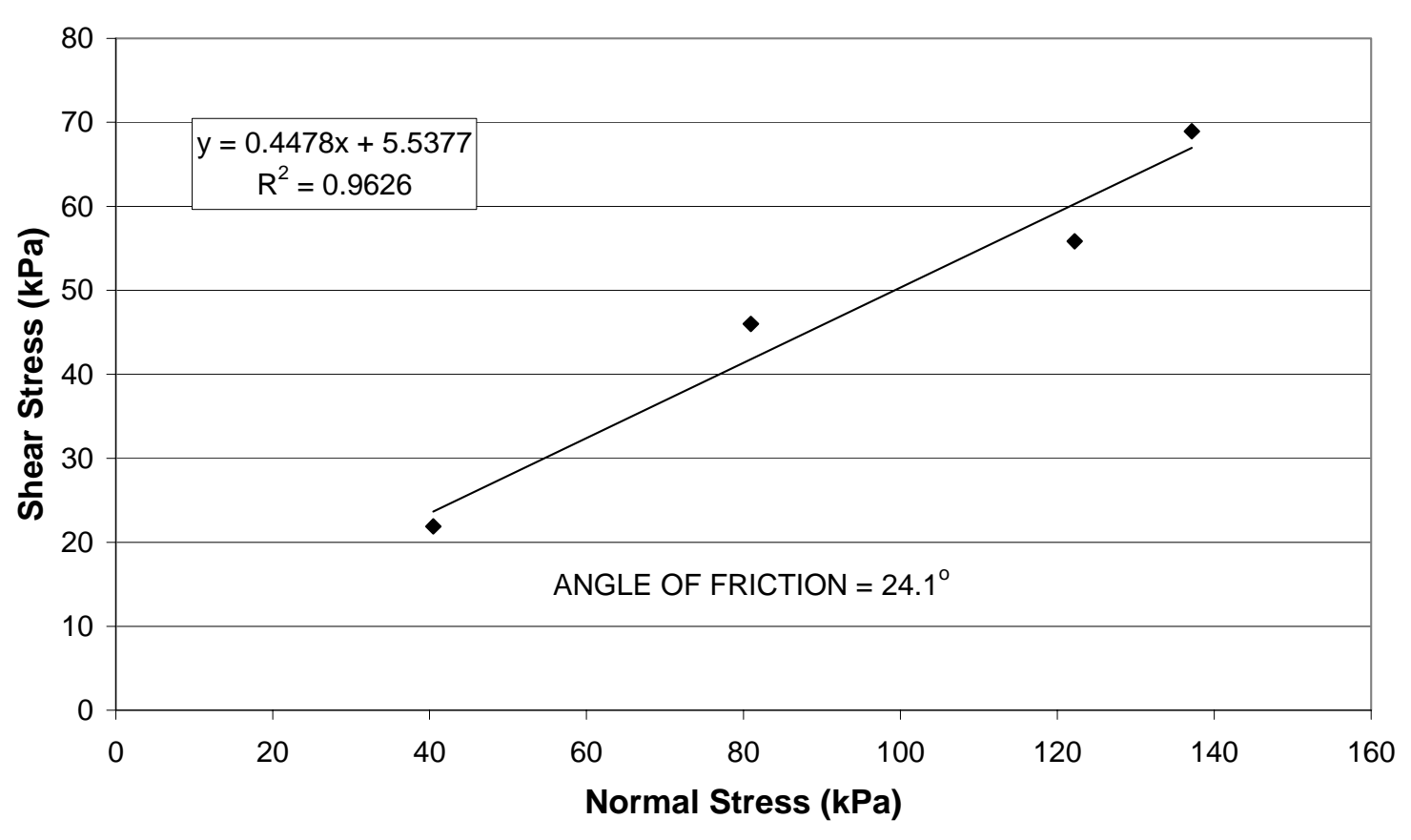

Figure 4.20: Direct shear failure envelope for sand-sand interface with $10 \%$ water content. 
Figures 4.21, 4.22 and 4.23 show the stress-strain relationship for material A-sand interface. Figure 4.24 shows the failure envelope for this interface. This failure envelope presents an angle of friction of 23.1 degrees and an effective cohesion of $5.6 \mathrm{kPa}$.

DIRECT SHEAR RESULTS

Sand-Sand Interface, $15 \%$ water content, $S_{n}=35.3 \mathrm{kPa}$

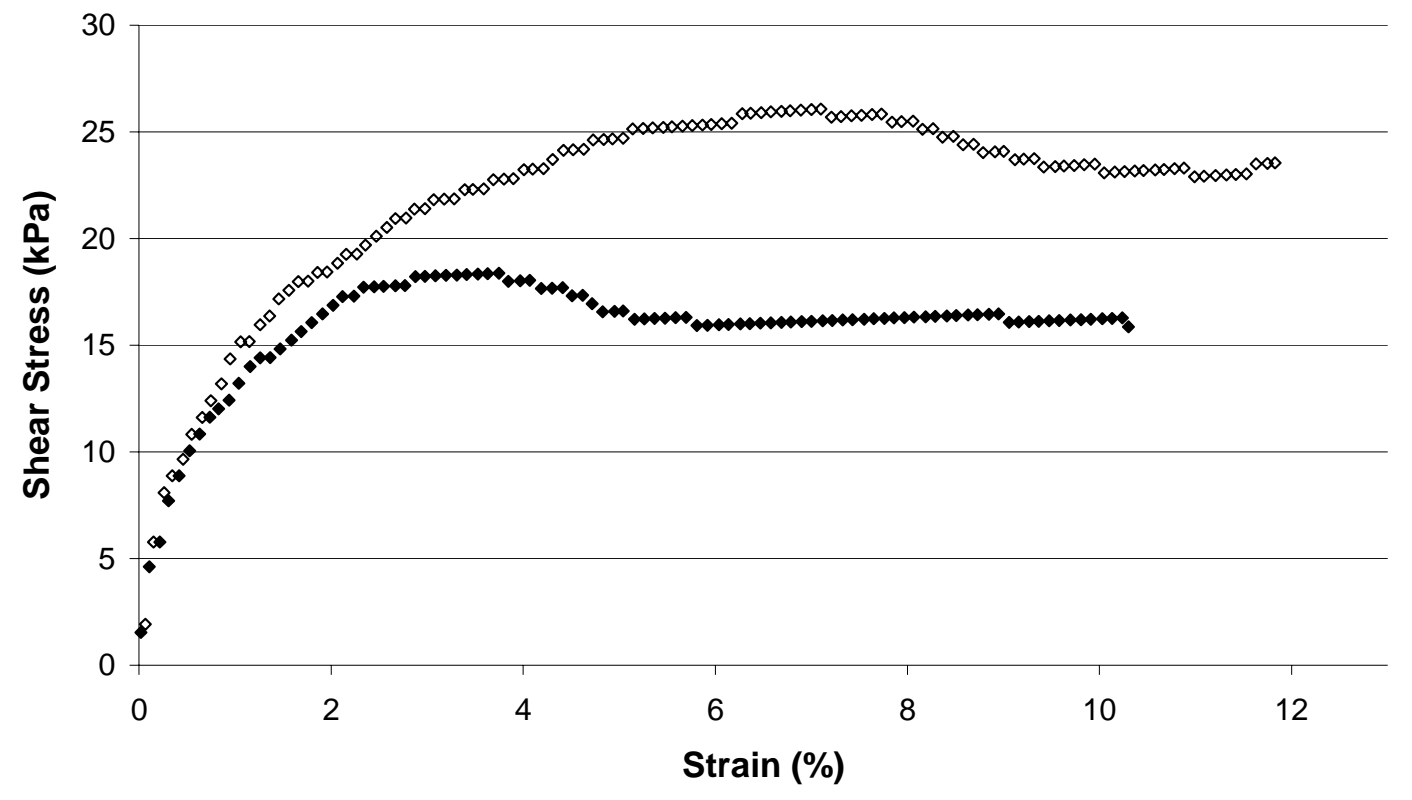

Figure 4.21: Direct shear test results for sand-sand interface at $\sigma_{\mathrm{n}}=35.3 \mathrm{kPa}$ with $15 \%$ water content. 
DIRECT SHEAR RESULTS

Sand-Sand Interface, $15 \%$ water content, $S_{n}=69.6 \mathrm{kPa}$

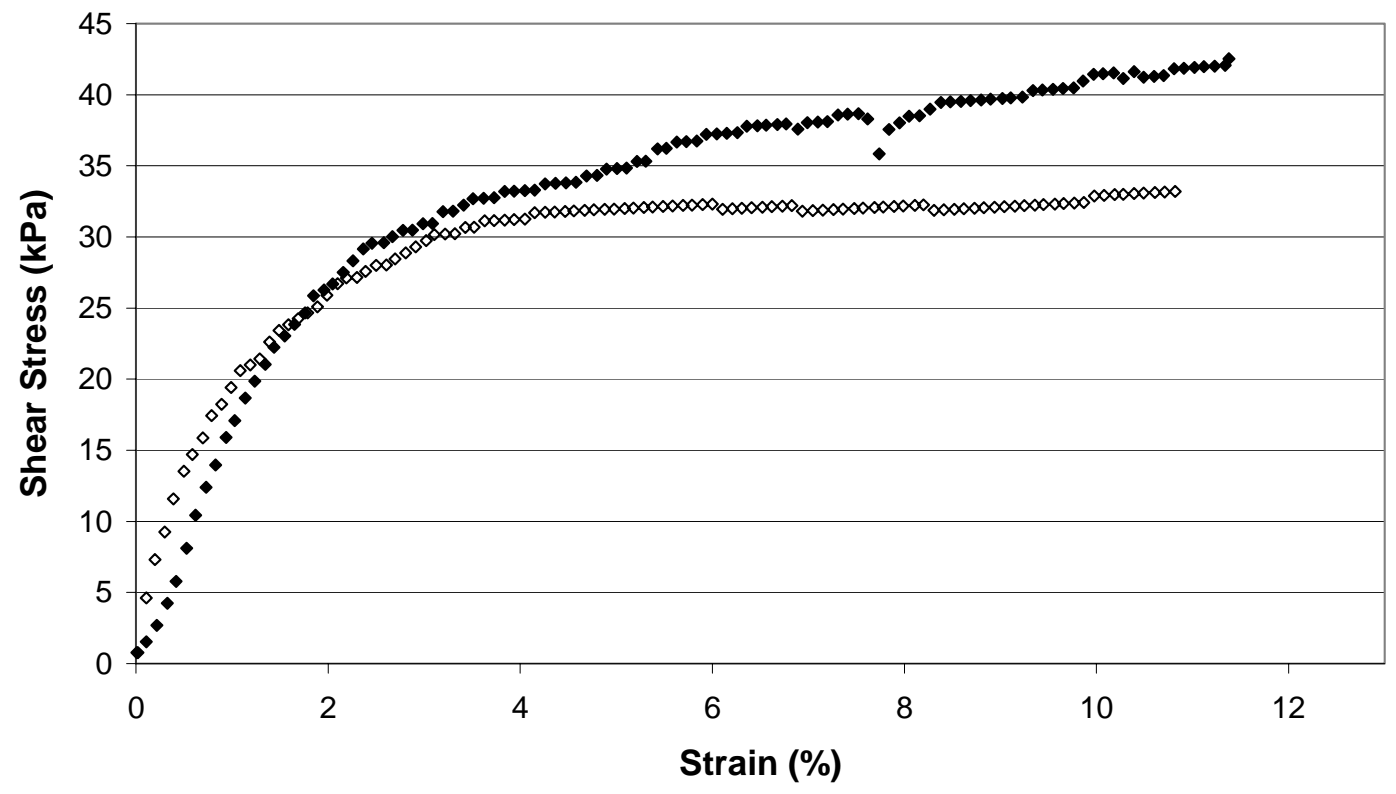

Figure 4.22: Direct shear test results for sand-sand interface at $\sigma_{\mathrm{n}}=69.6 \mathrm{kPa}$ with $15 \%$ water content. 


\section{DIRECT SHEAR RESULTS}

\section{Sand-Sand Interface, $15 \%$ water content, $S_{n}=103.9 \mathrm{kPa}$}

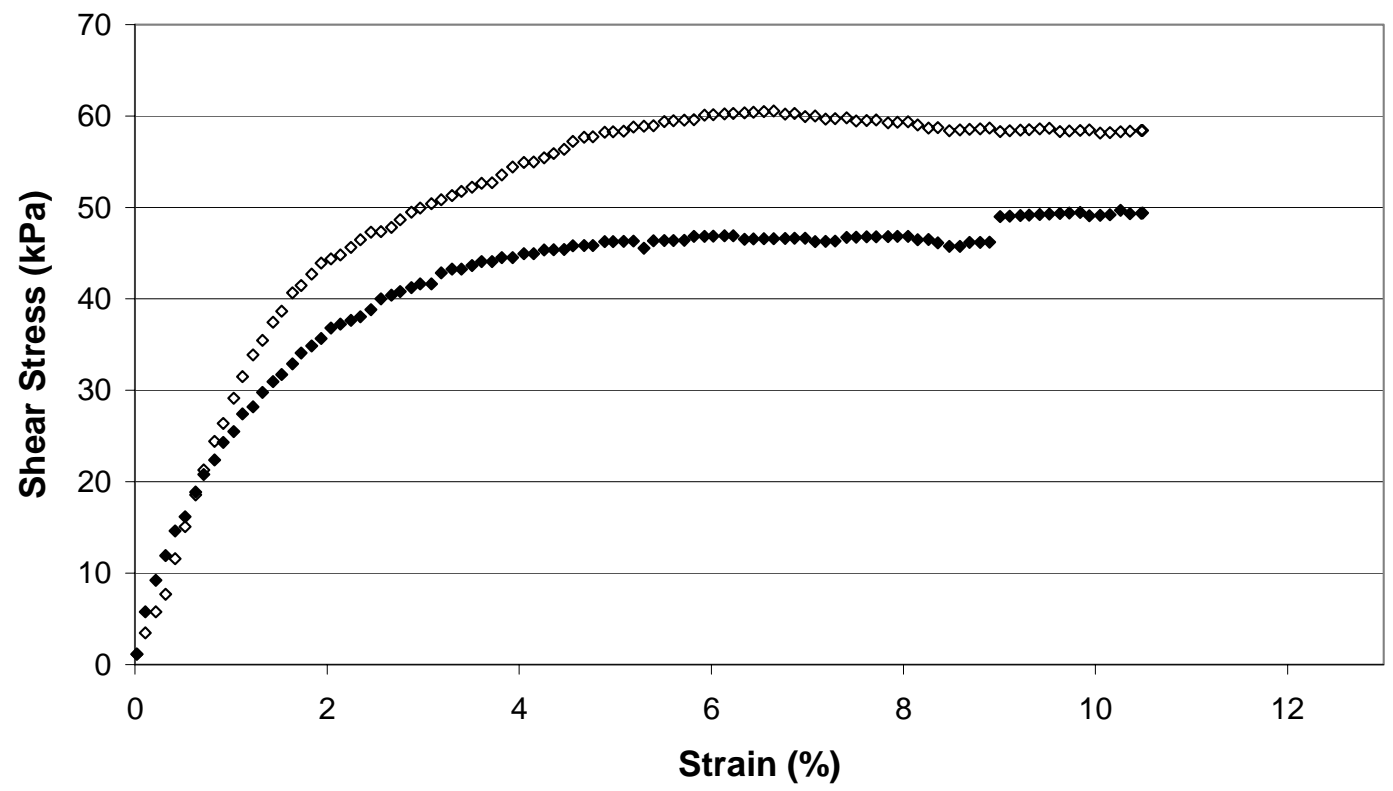

Figure 4.23: Direct shear test results for sand-sand interface at $\sigma_{\mathrm{n}}=103.9 \mathrm{kPa}$ with $15 \%$ water content. 
DIRECT SHEAR FAILURE ENVELOPE

Sand-Sand Interface, 15\% water content

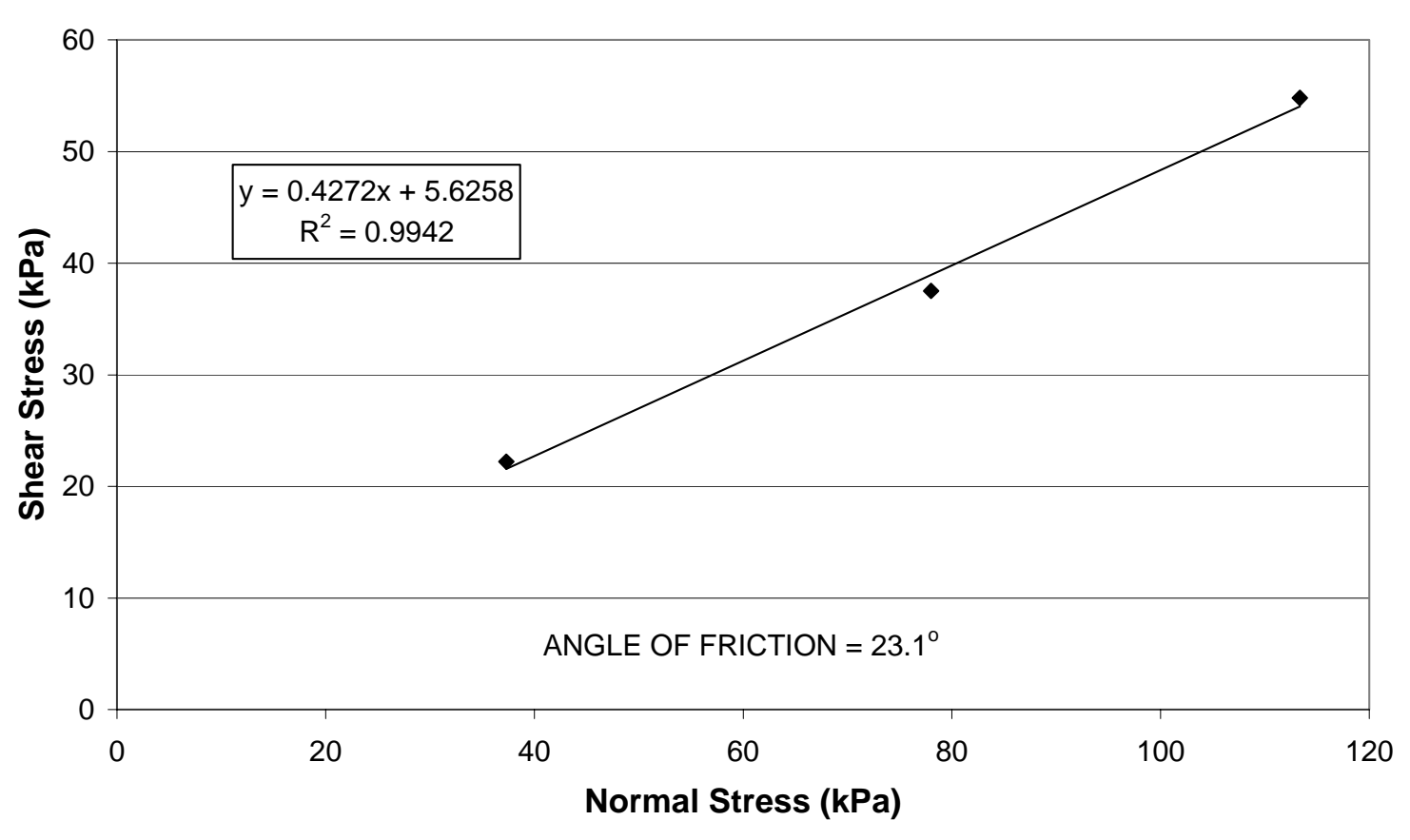

Figure 4.24: Direct shear failure envelope for sand-sand interface with $15 \%$ water content. 
In the following three figures, Figure 4.25, 4.26 and 4.27, the direct shear stressstrain relationship for material B-sand is presented. An angle of friction equal to 30.2 degrees is shown in Figure 4.28. This figure illustrates the failure envelope for the interface and shows an effective cohesion of $0.6 \mathrm{kPa}$.

DIRECT SHEAR RESULTS

Silt-Silt Interface, $0 \%$ water content, $S_{n}=35.3 \mathrm{kPa}$

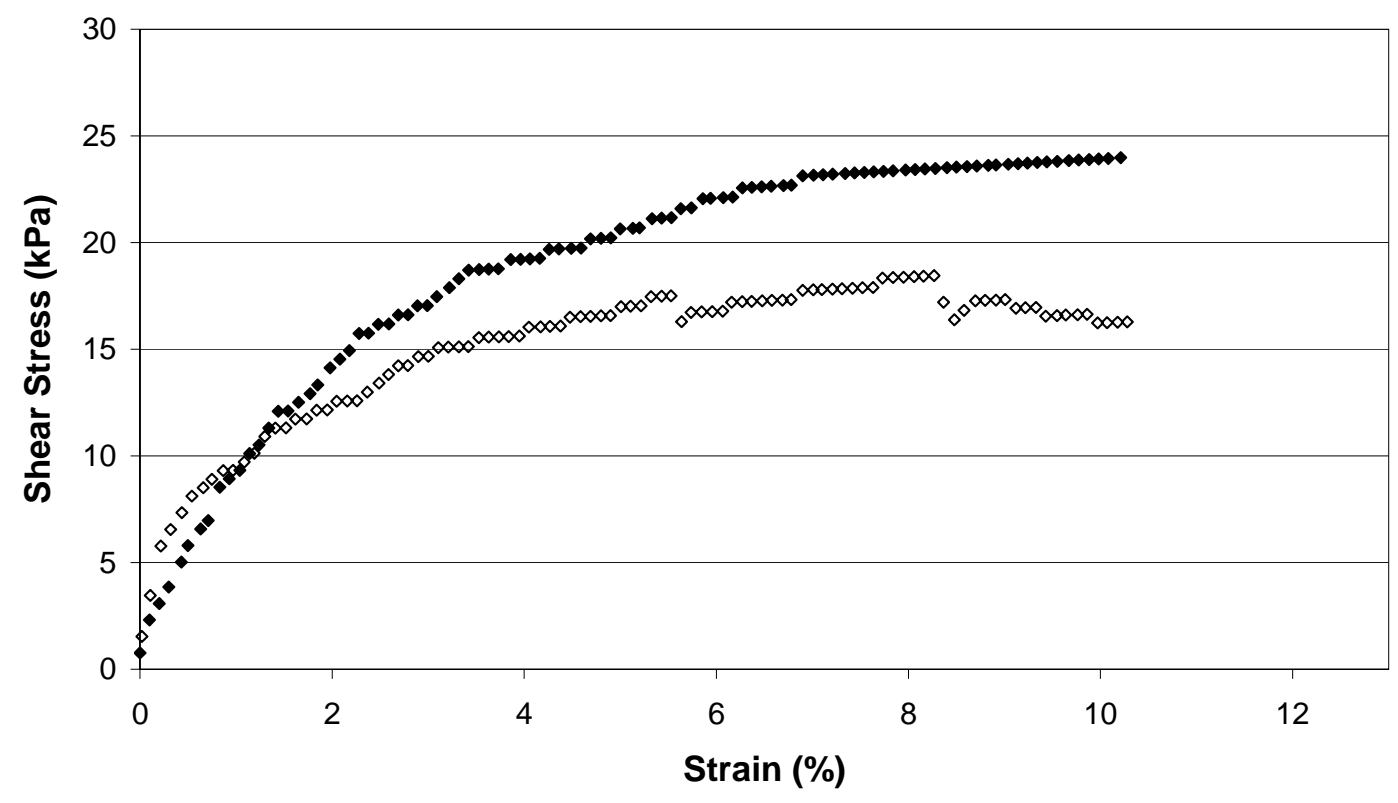

Figure 4.25: Direct shear test results for silt-silt interface at $\sigma_{\mathrm{n}}=35.3 \mathrm{kPa}$ with $0 \%$ water content. 
DIRECT SHEAR RESULTS

Silt-Silt Interface, $0 \%$ water content, $S_{n}=69.6 \mathrm{kPa}$

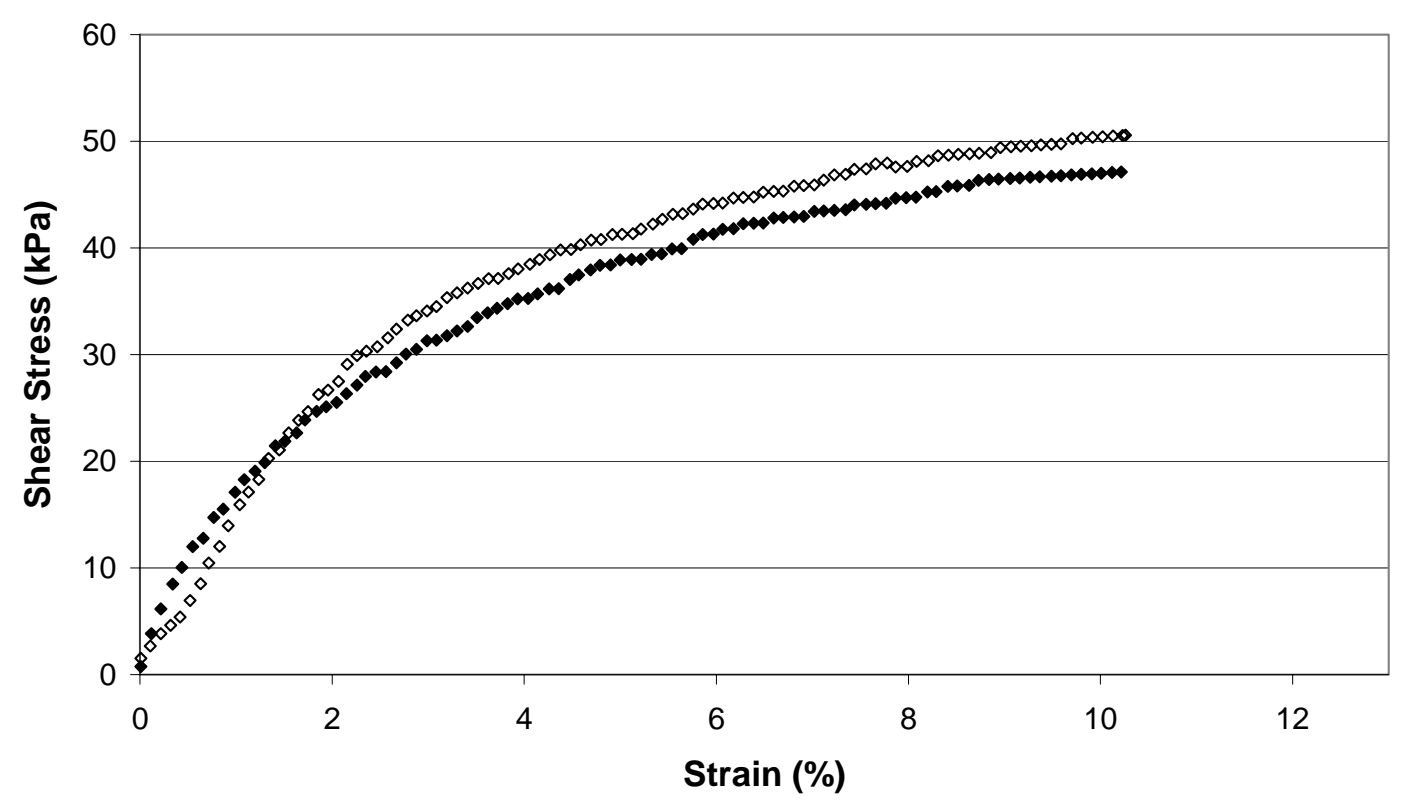

Figure 4.26: Direct shear test results for silt-silt interface at $\sigma_{\mathrm{n}}=69.6 \mathrm{kPa}$ with $0 \%$ water content. 
DIRECT SHEAR RESULTS

Silt-Silt Interface, $0 \%$ water content, $S_{n}=103.9 \mathrm{kPa}$

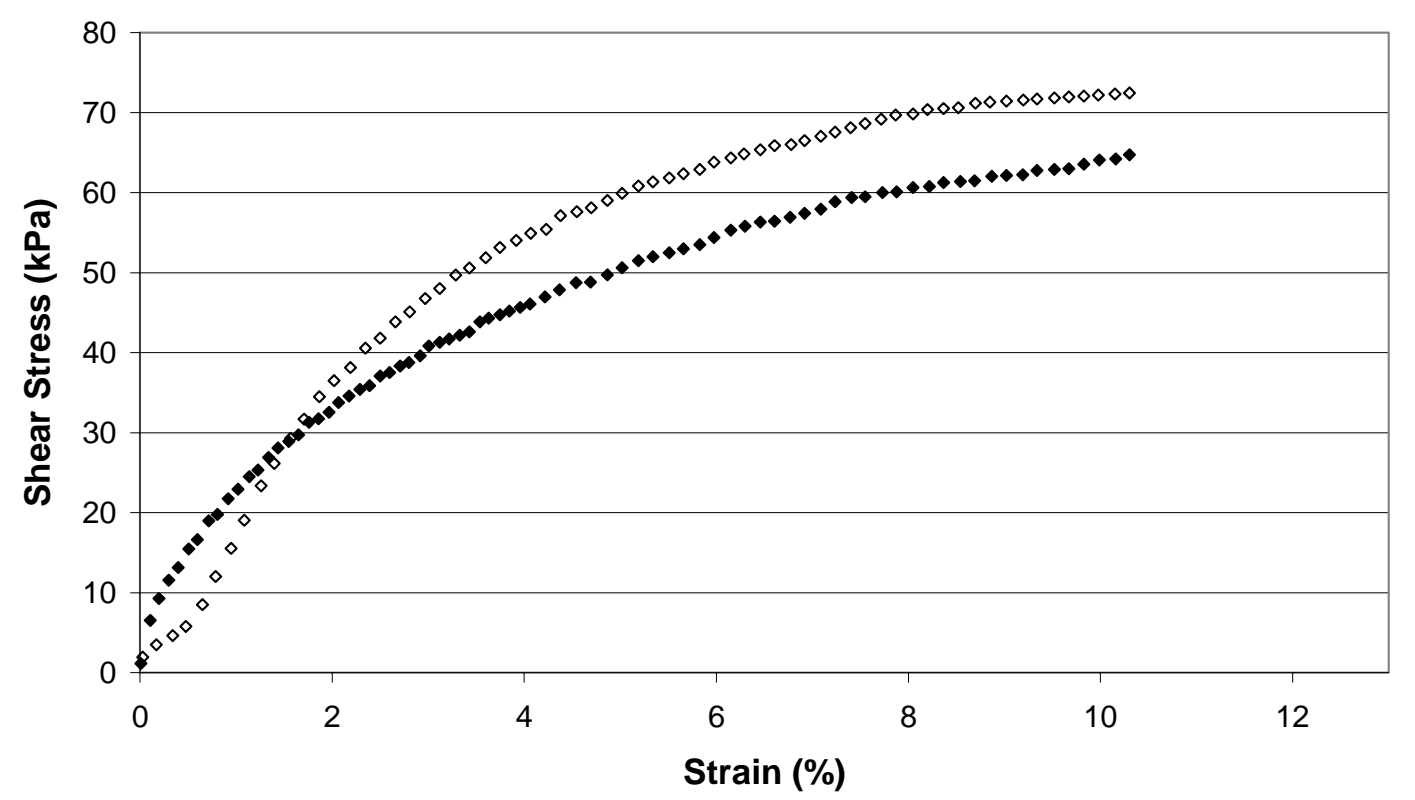

Figure 4.27: Direct shear test results for silt-silt interface at $\sigma_{\mathrm{n}}=103.9 \mathrm{kPa}$ with $0 \%$ water content. 
DIRECT SHEAR FAILURE ENVELOPE

Silt-Silt Interface, $0 \%$ water content

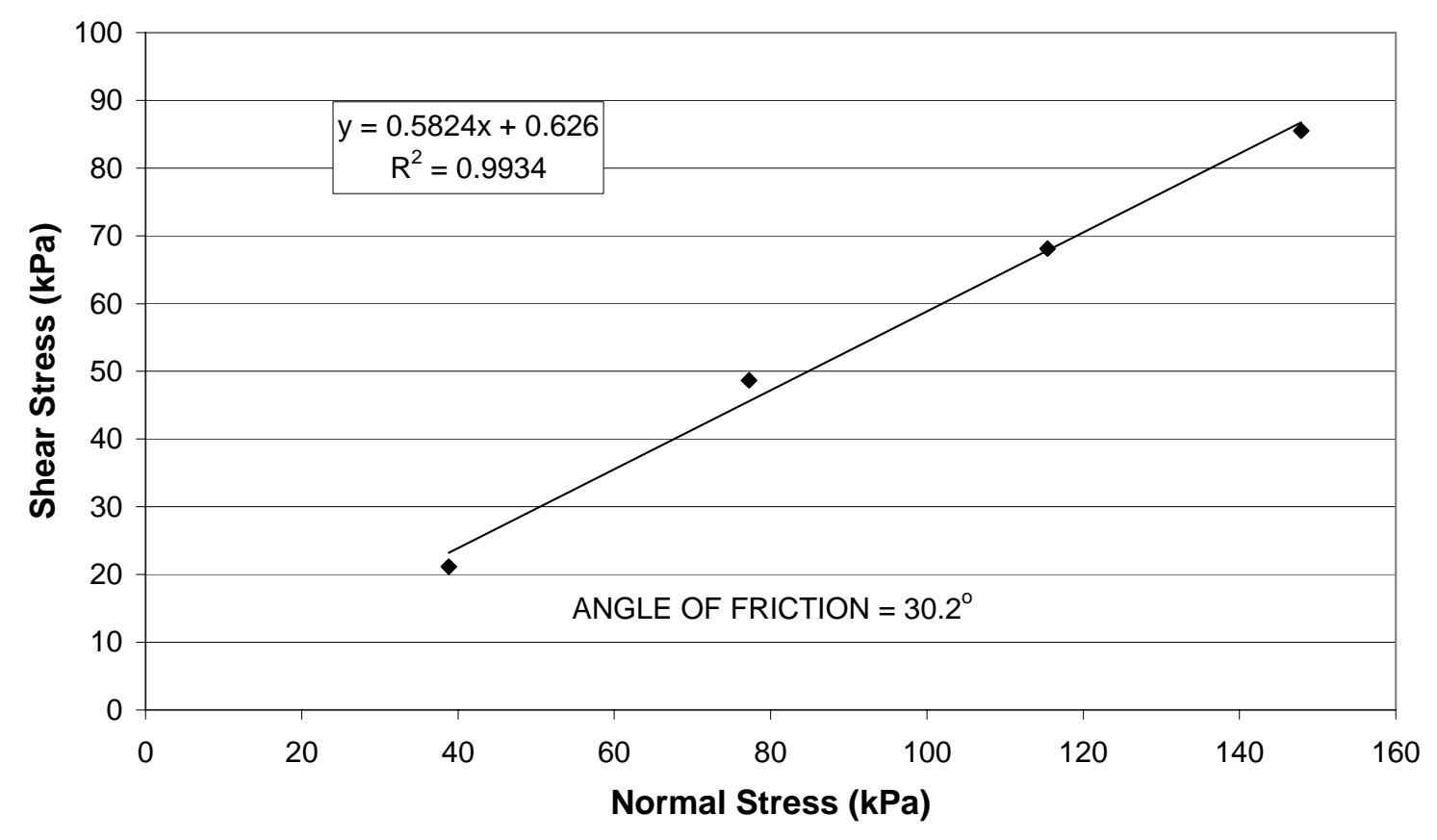

Figure 4.28: Direct shear failure envelope for silt-silt interface with $0 \%$ water content. 
Figures 4.29, 4.30 and 4.31 show the direct shear stress-strain relationship for sand-sand interface. Figure 4.32 illustrates the failure envelope for this interface. An angle of friction equal to 26.2 degrees and an effective cohesion of $4.9 \mathrm{kPa}$ were recorded.

\section{DIRECT SHEAR RESULTS}

Silt-Silt Interface, $10 \%$ water content, $S_{n}=35.3 \mathrm{kPa}$

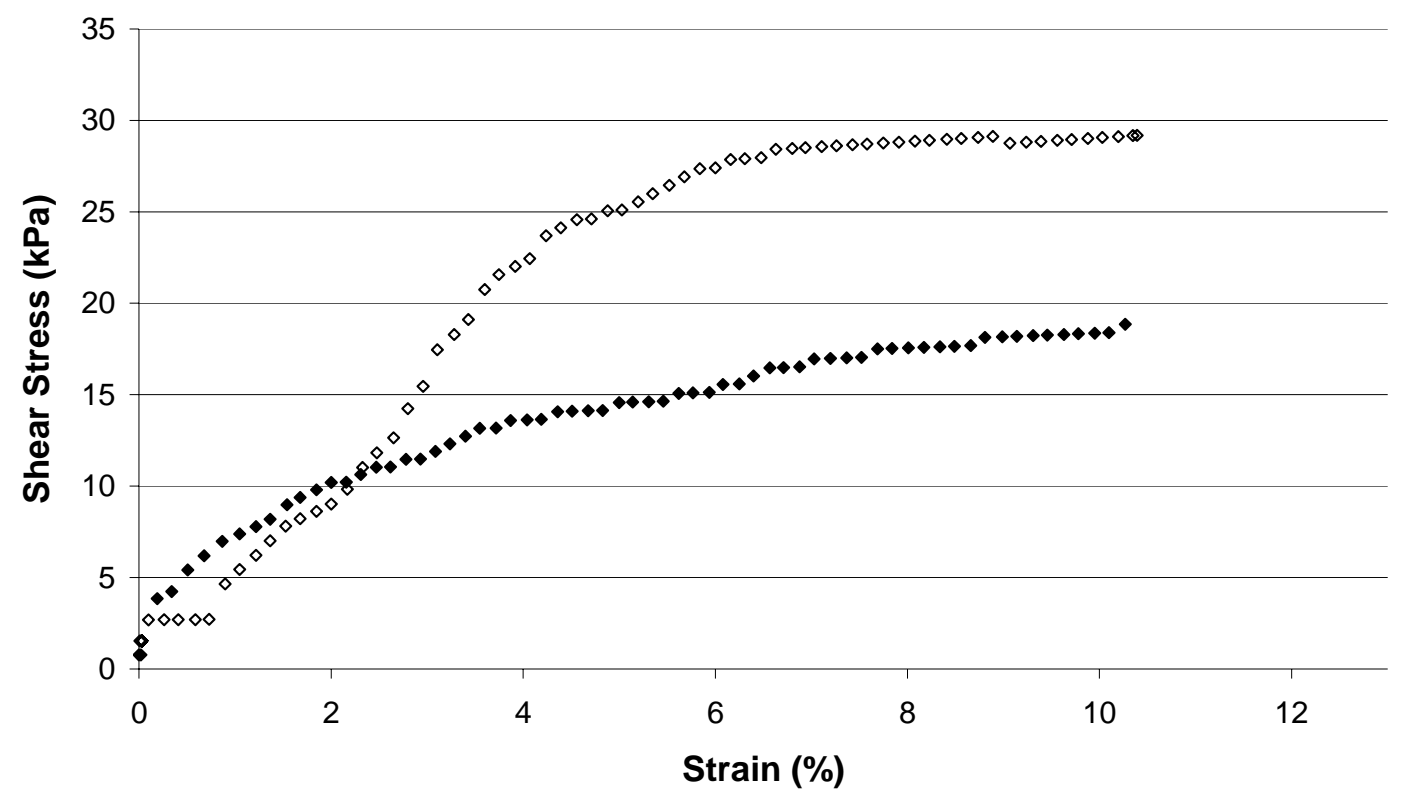

Figure 4.29: Direct shear test results for silt-silt interface at $\sigma_{\mathrm{n}}=35.3 \mathrm{kPa}$ with $10 \%$ water content. 


\section{DIRECT SHEAR RESULTS}

Silt-Silt Interface, $10 \%$ water content, $S_{n}=69.6 \mathrm{kPa}$

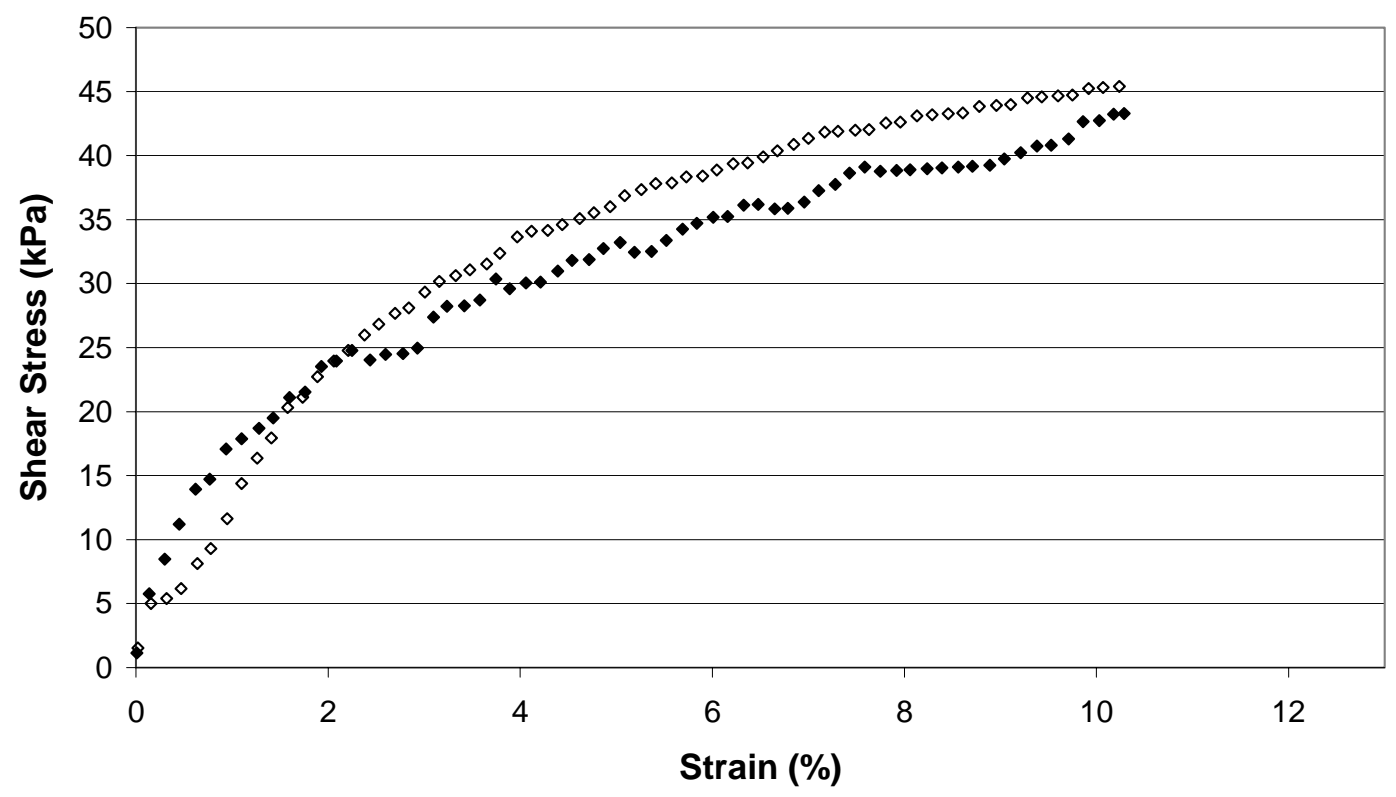

Figure 4.30: Direct shear test results for silt-silt interface at $\sigma_{\mathrm{n}}=69.6 \mathrm{kPa}$ with $10 \%$ water content. 
DIRECT SHEAR RESULTS

Silt-Silt Interface, $10 \%$ water content, $S_{n}=103.9 \mathrm{kPa}$

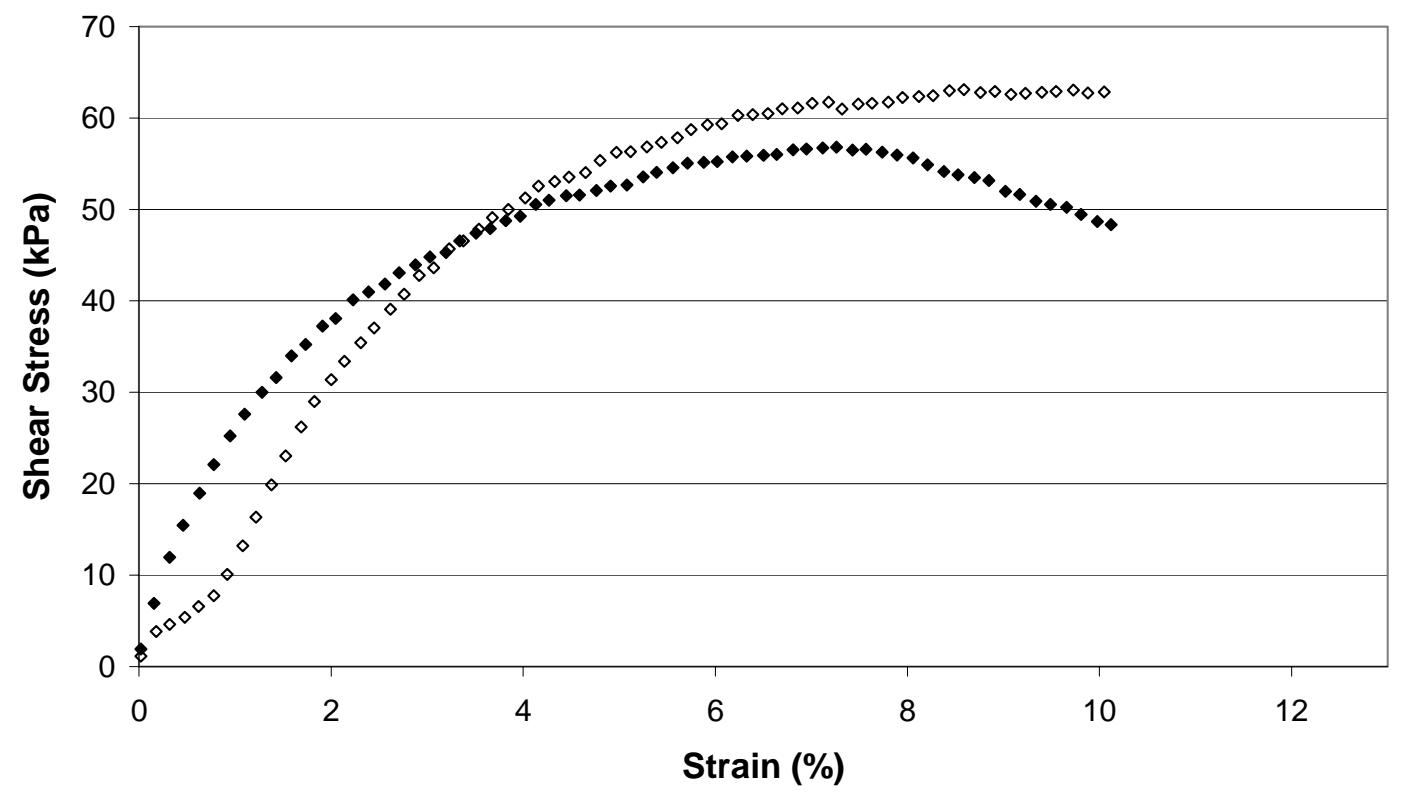

Figure 4.31: Direct shear test results for silt-silt interface at $\sigma_{\mathrm{n}}=103.9 \mathrm{kPa}$ with $10 \%$ water content. 
DIRECT SHEAR FAILURE ENVELOPE

Silt-Silt Interface, $10 \%$ water content

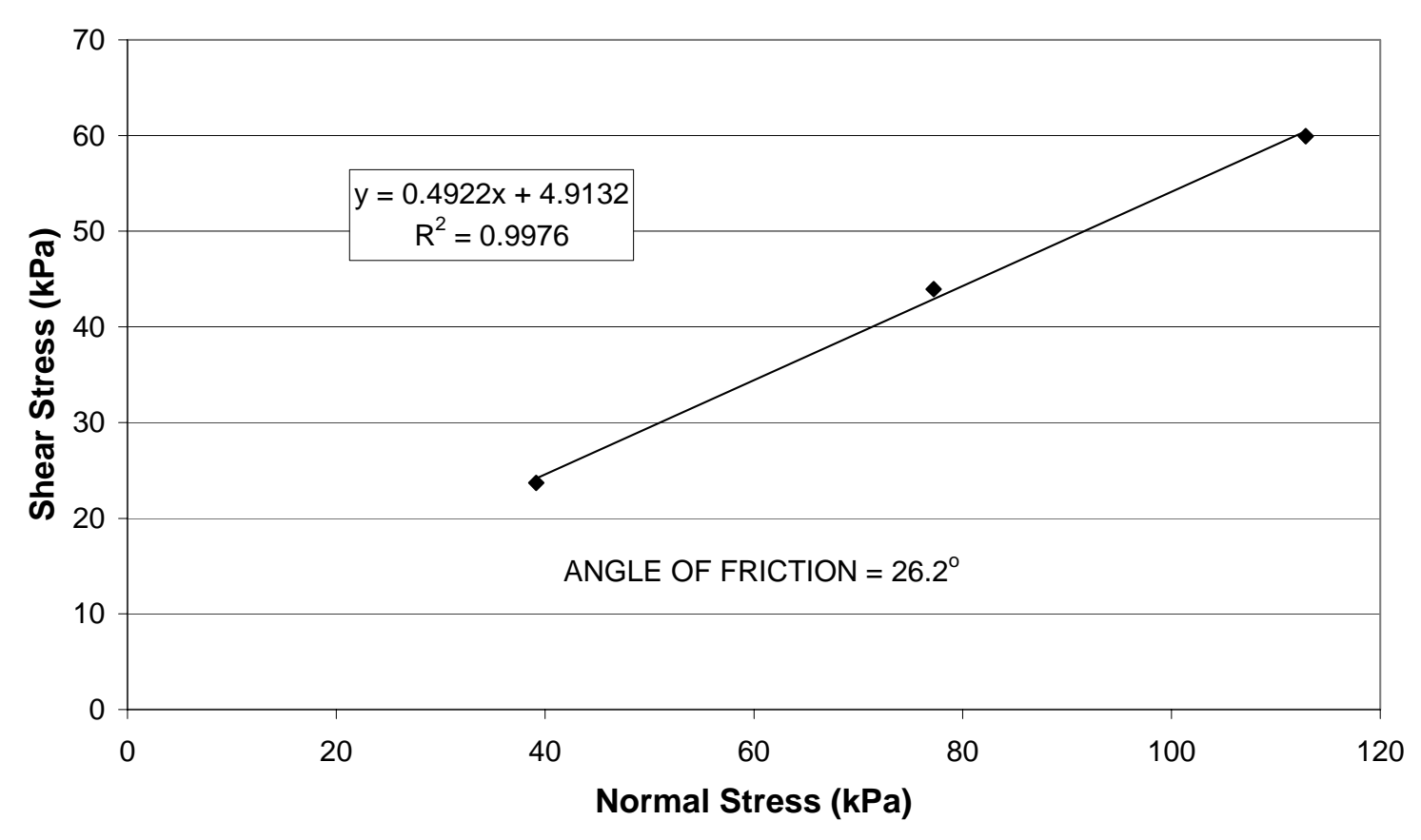

Figure 4.32: Direct shear failure envelope for silt-silt interface with $10 \%$ water content. 
Figures 4.33, 4.34 and 4.35 show the stress-strain relationship for material A-sand interface. Figure 4.36 shows the failure envelope for this interface. This failure envelope presents an angle of friction of 22.3 degrees and an effective cohesion of $12.2 \mathrm{kPa}$.

DIRECT SHEAR RESULTS

Silt-Silt Interface, $15 \%$ water content, $S_{n}=35.3 \mathrm{kPa}$

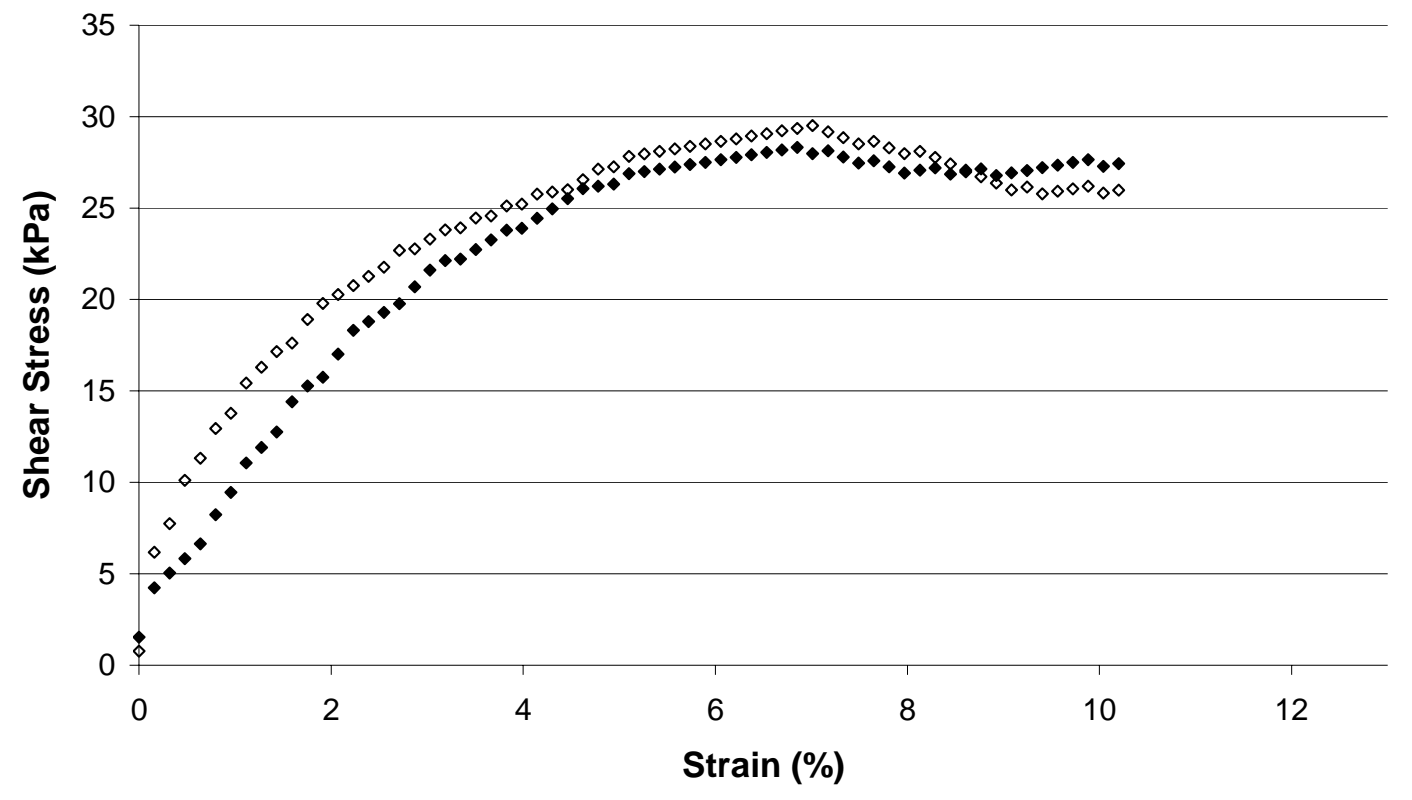

Figure 4.33: Direct shear test results for silt-silt interface at $\sigma_{\mathrm{n}}=35.3 \mathrm{kPa}$ with $15 \%$ water content. 
DIRECT SHEAR RESULTS

Silt-Silt Interface, $15 \%$ water content, $S_{n}=69.6 \mathrm{kPa}$

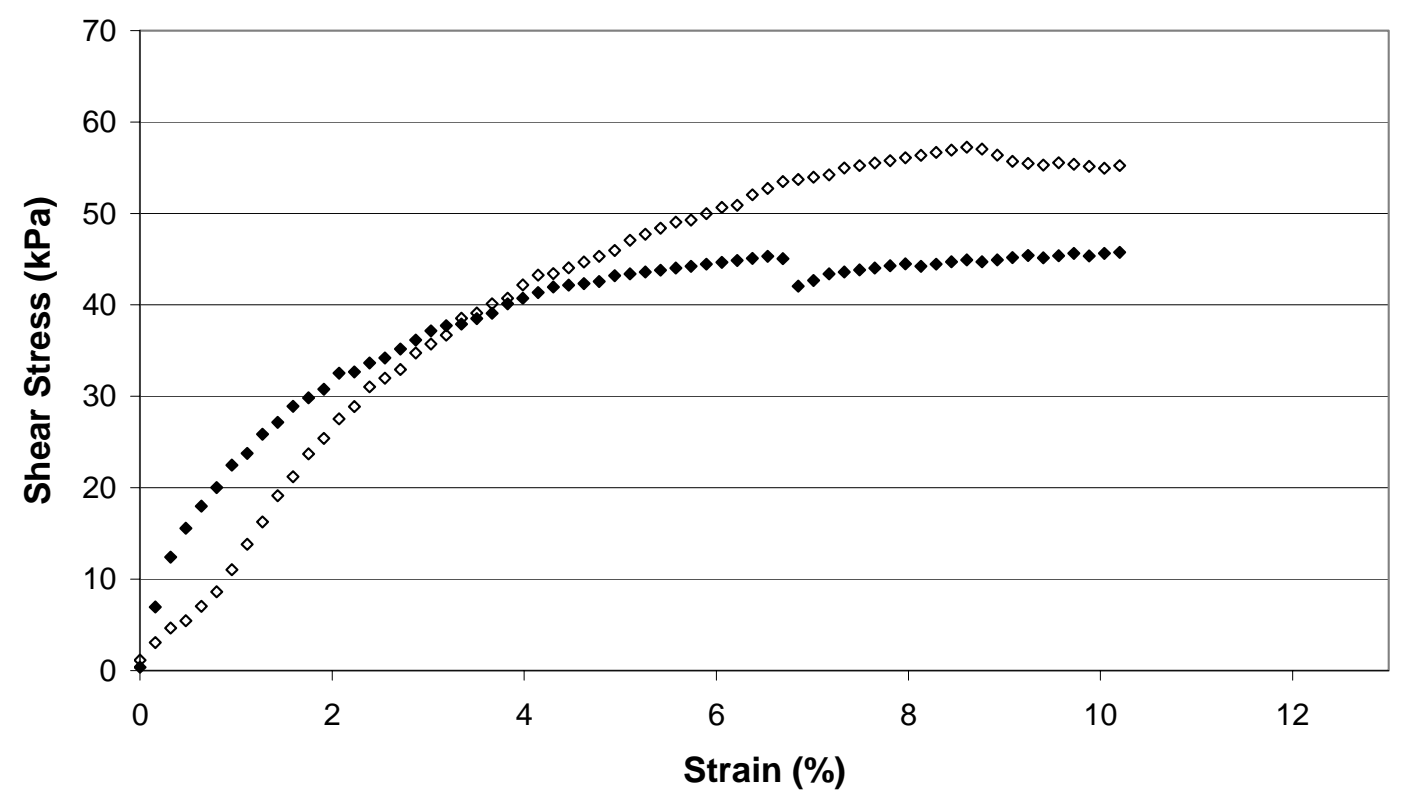

Figure 4.34: Direct shear test results for silt-silt interface at $\sigma_{\mathrm{n}}=69.6 \mathrm{kPa}$ with $15 \%$ water content. 
DIRECT SHEAR RESULTS

Silt-Silt Interface, $15 \%$ water content, $S_{n}=103.9 \mathrm{kPa}$

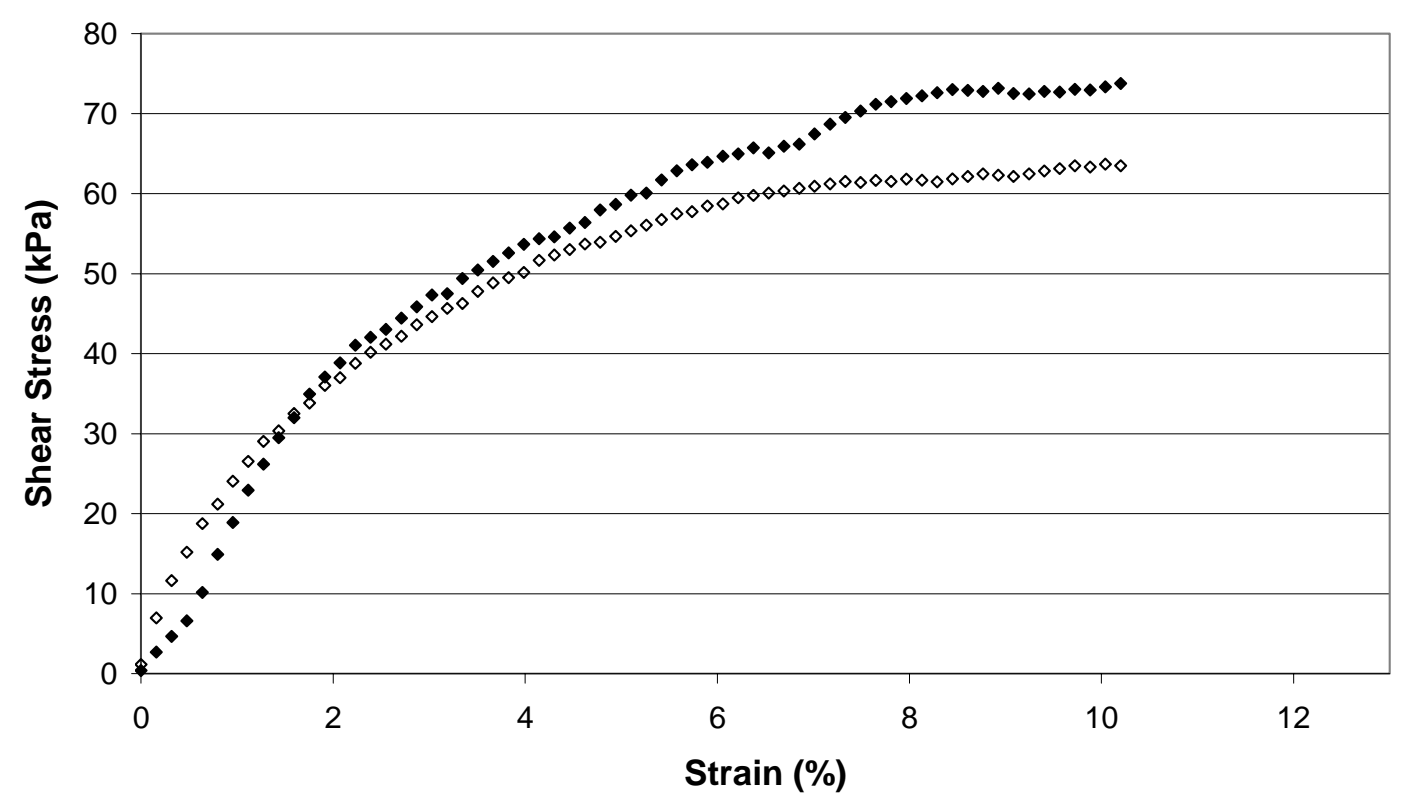

Figure 4.35: Direct shear test results for silt-silt interface at $\sigma_{\mathrm{n}}=103.9 \mathrm{kPa}$ with $15 \%$ water content. 
DIRECT SHEAR FAILURE ENVELOPE

Silt-Silt Interface, $15 \%$ water content

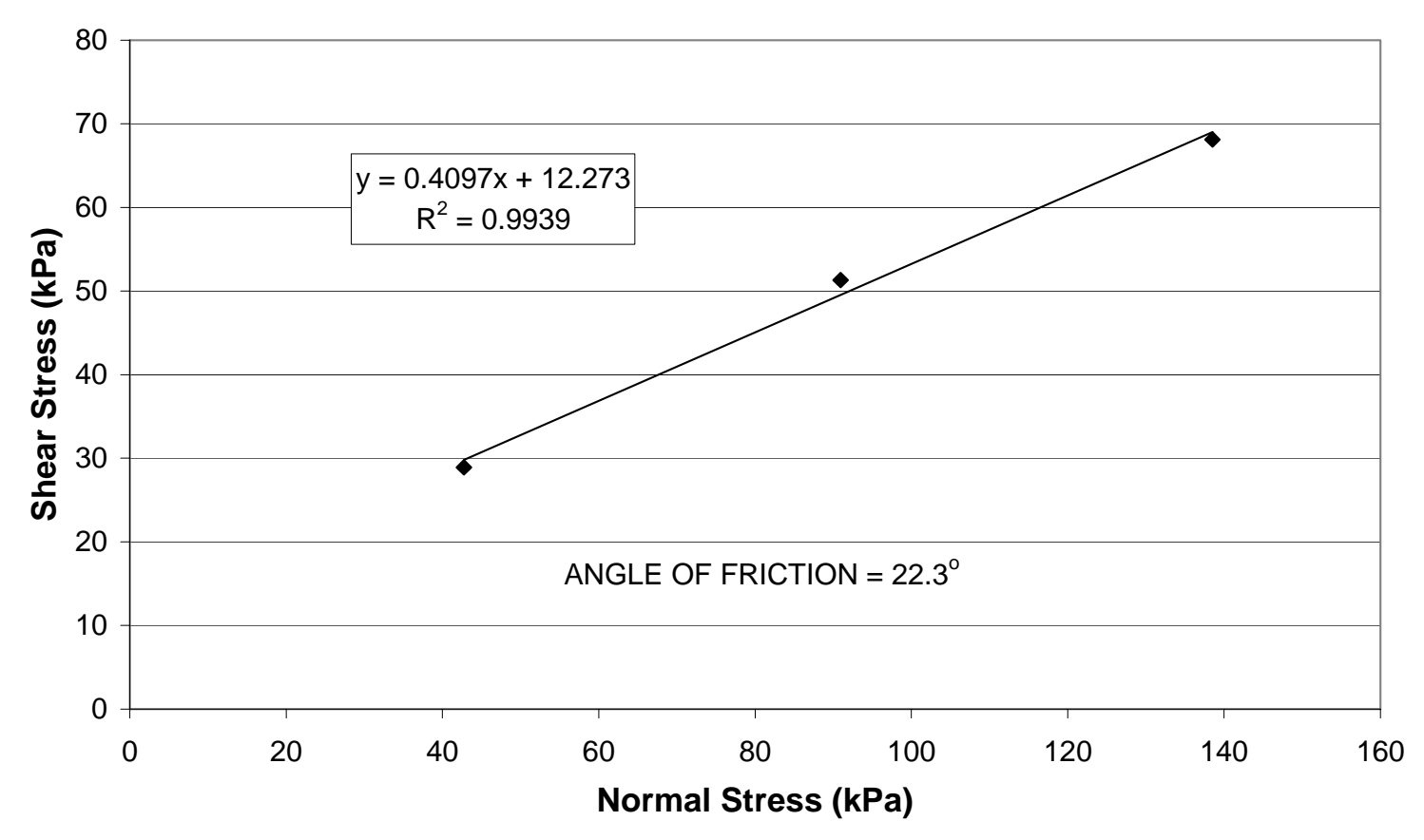

Figure 4.36: Direct shear failure envelope for silt-silt interface with $15 \%$ water content. 
In the following three figures, Figure 4.37, 4.38 and 4.39, the direct shear stressstrain relationship for material B-sand is presented. An angle of friction equal to 31.7 degrees is shown in Figure 4.40. This figure illustrates the failure envelope for the interface and shows an effective cohesion of $2.9 \mathrm{kPa}$.

DIRECT SHEAR RESULTS

Clay-Clay Interface, $0 \%$ water content, $S_{n}=35.3 \mathrm{kPa}$

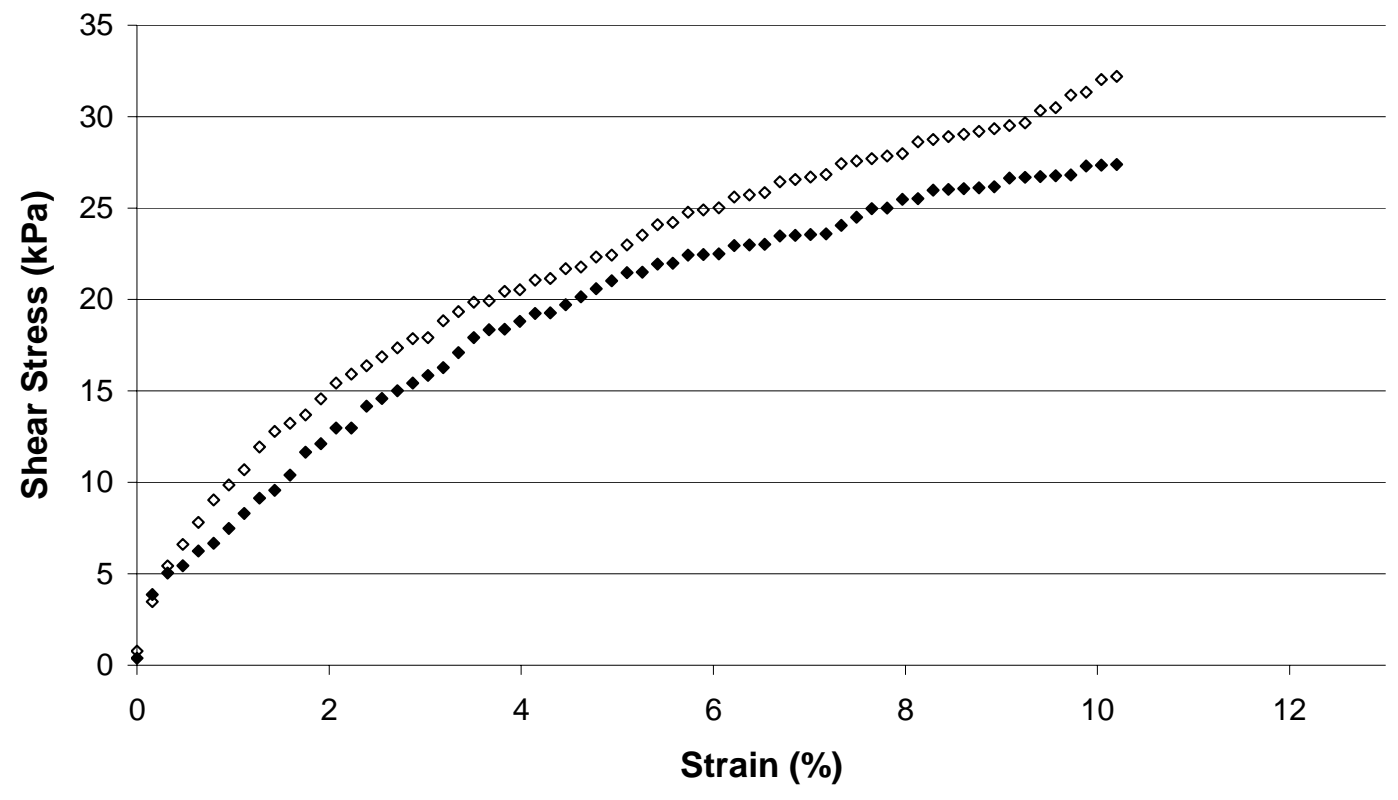

Figure 4.37: Direct shear test results for clay-clay interface at $\sigma_{\mathrm{n}}=35.3 \mathrm{kPa}$ with $0 \%$ water content. 
DIRECT SHEAR RESULTS

Clay-Clay Interface, $0 \%$ water content, $S_{n}=69.6 \mathrm{kPa}$

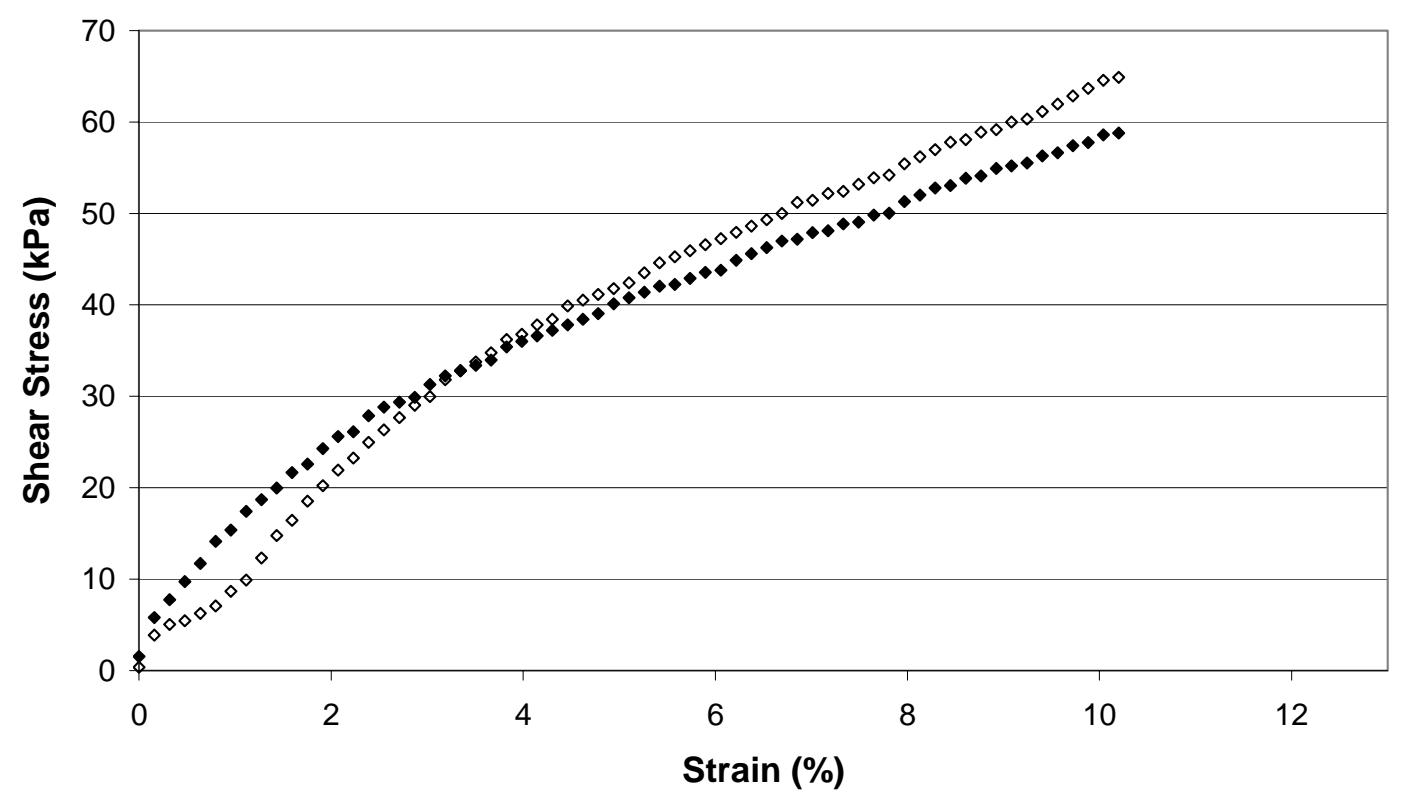

Figure 4.38: Direct shear test results for clay-clay interface at $\sigma_{\mathrm{n}}=69.6 \mathrm{kPa}$ with $0 \%$ water content. 


\section{DIRECT SHEAR RESULTS}

Clay-Clay Interface, $0 \%$ water content, $S_{n}=103.9 \mathrm{kPa}$

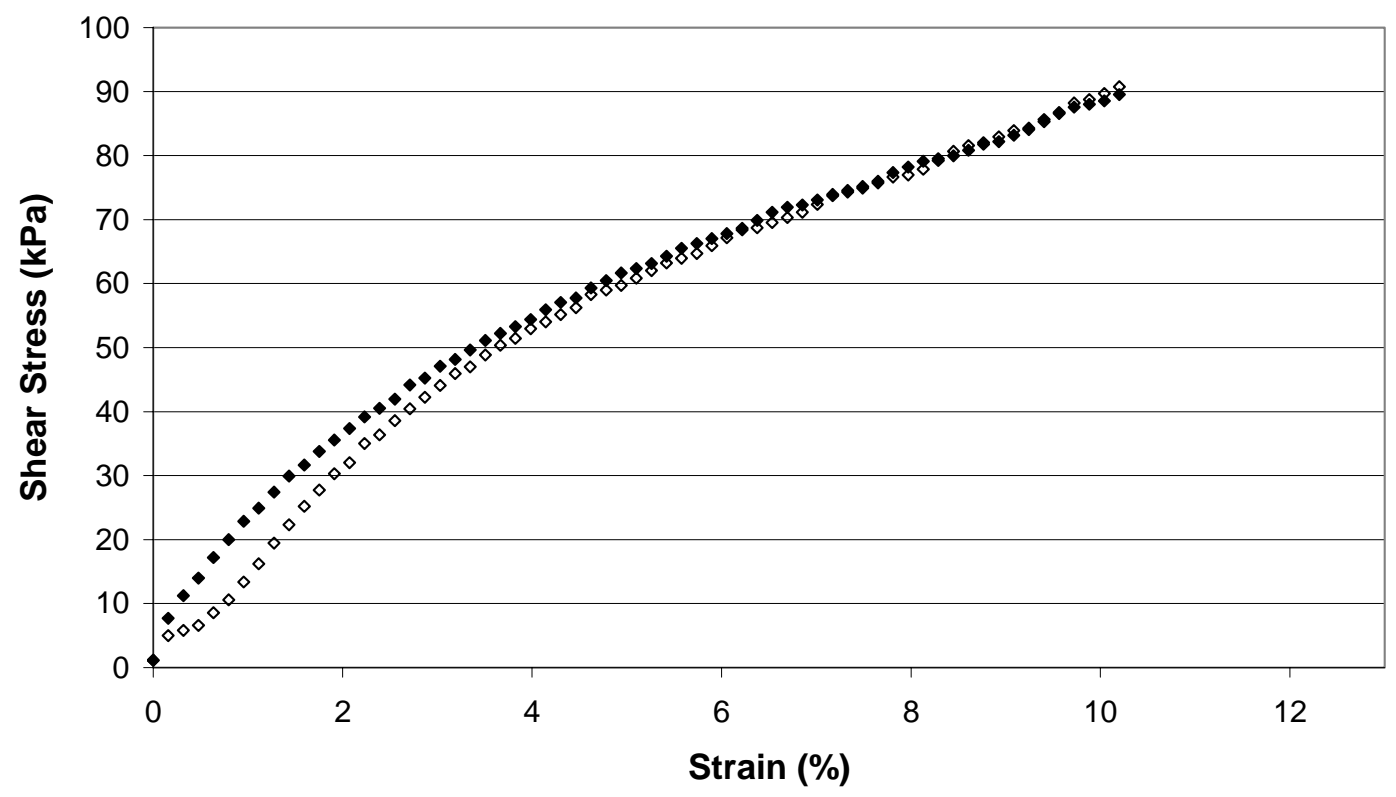

Figure 4.39: Direct shear test results for clay-clay interface at $\sigma_{\mathrm{n}}=103.9 \mathrm{kPa}$ with $0 \%$ water content. 
DIRECT SHEAR FAILURE ENVELOPE Clay-Clay Interface, $0 \%$ water content

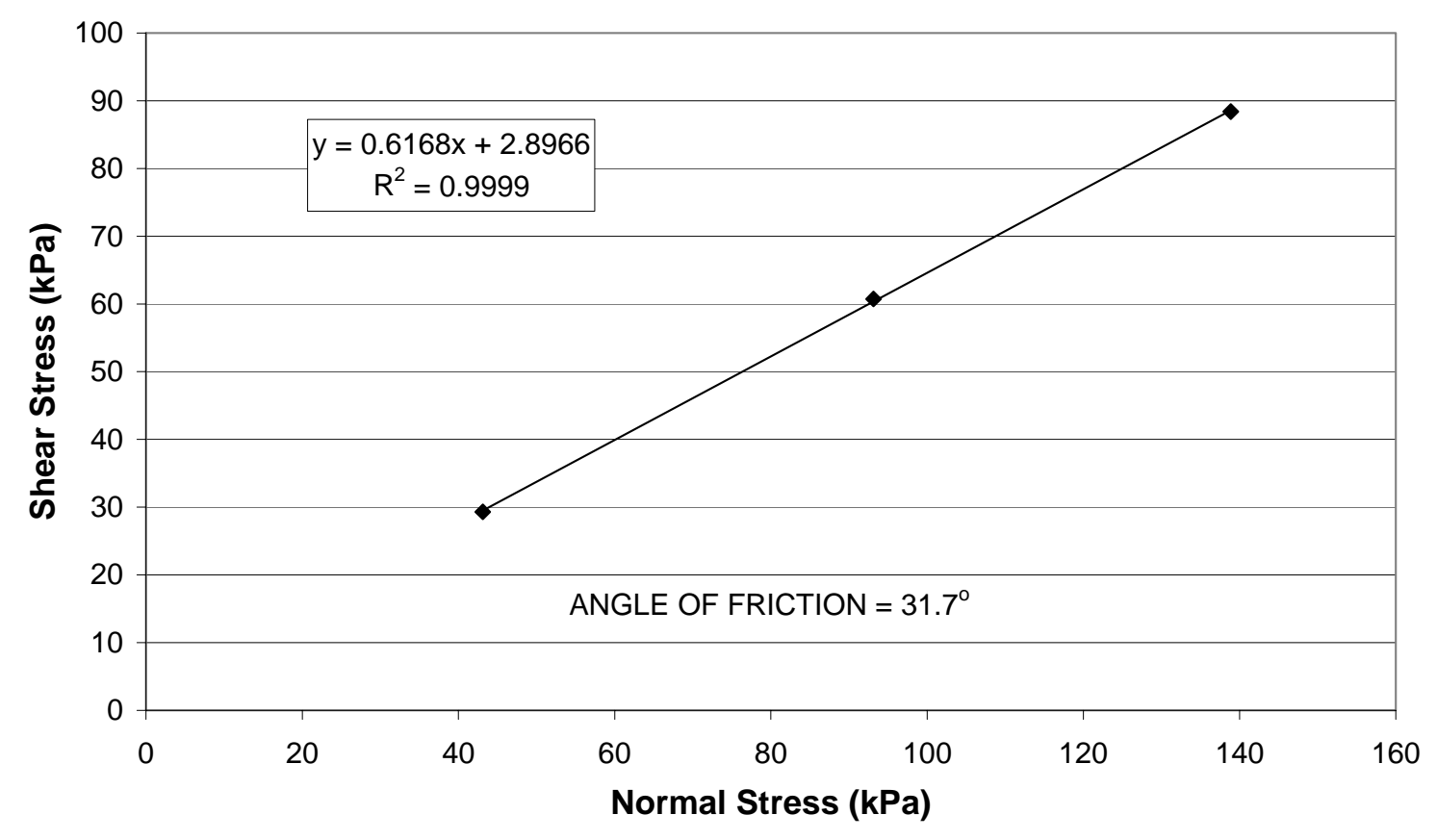

Figure 4.40: Direct shear failure envelope for clay-clay interface with $0 \%$ water content. 
Figures 4.41, 4.42 and 4.43 show the direct shear stress-strain relationship for sand-sand interface. Figure 4.44 illustrates the failure envelope for this interface. An angle of friction equal to 29.4 degrees and an effective cohesion of $9.6 \mathrm{kPa}$ were recorded.

\section{DIRECT SHEAR RESULTS}

Clay-Clay Interface, $10 \%$ water content, $S_{n}=35.3 \mathrm{kPa}$

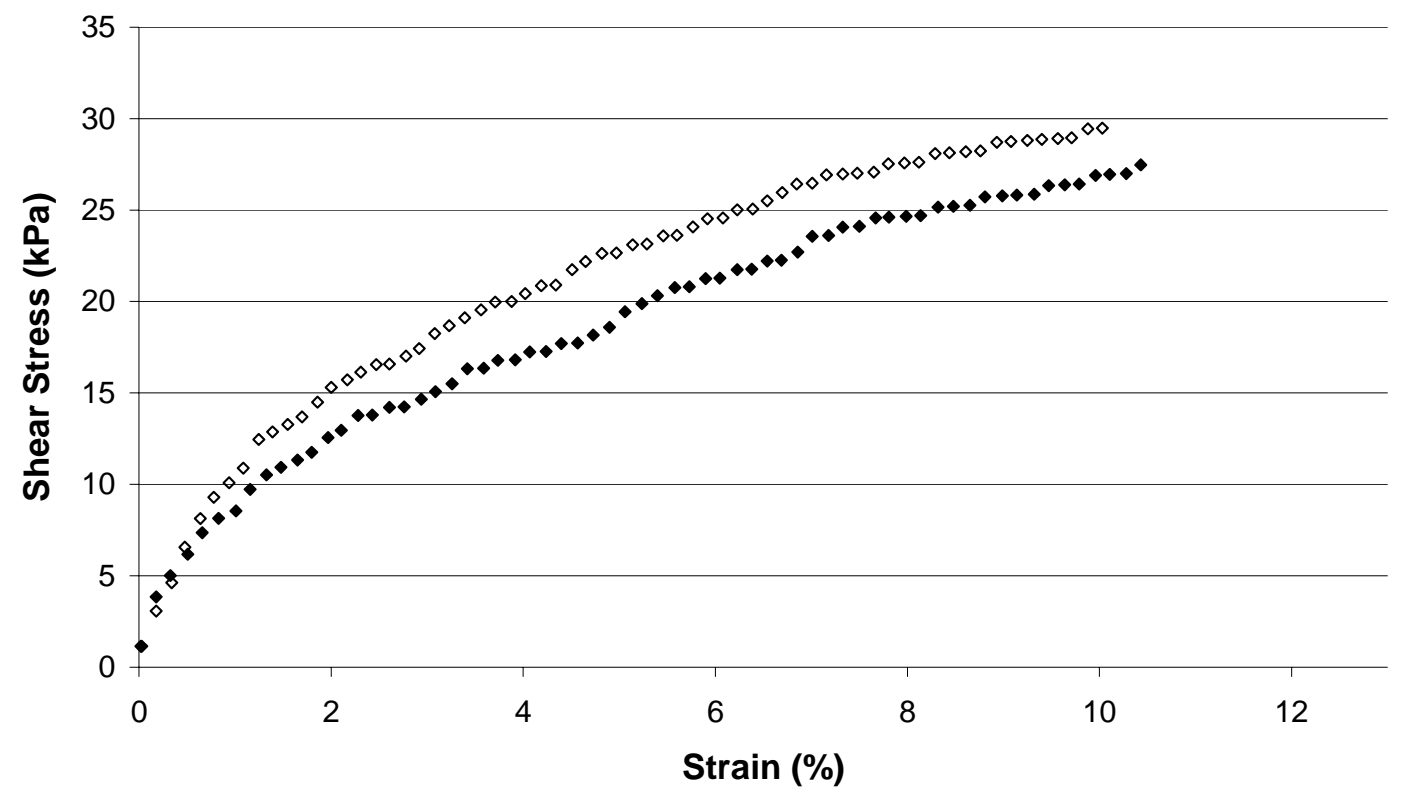

Figure 4.41: Direct shear test results for clay-clay interface at $\sigma_{\mathrm{n}}=35.3 \mathrm{kPa}$ with $10 \%$ water content. 


\section{DIRECT SHEAR RESULTS}

Clay-Clay Interface, $10 \%$ water content, $S_{n}=69.6 \mathrm{kPa}$

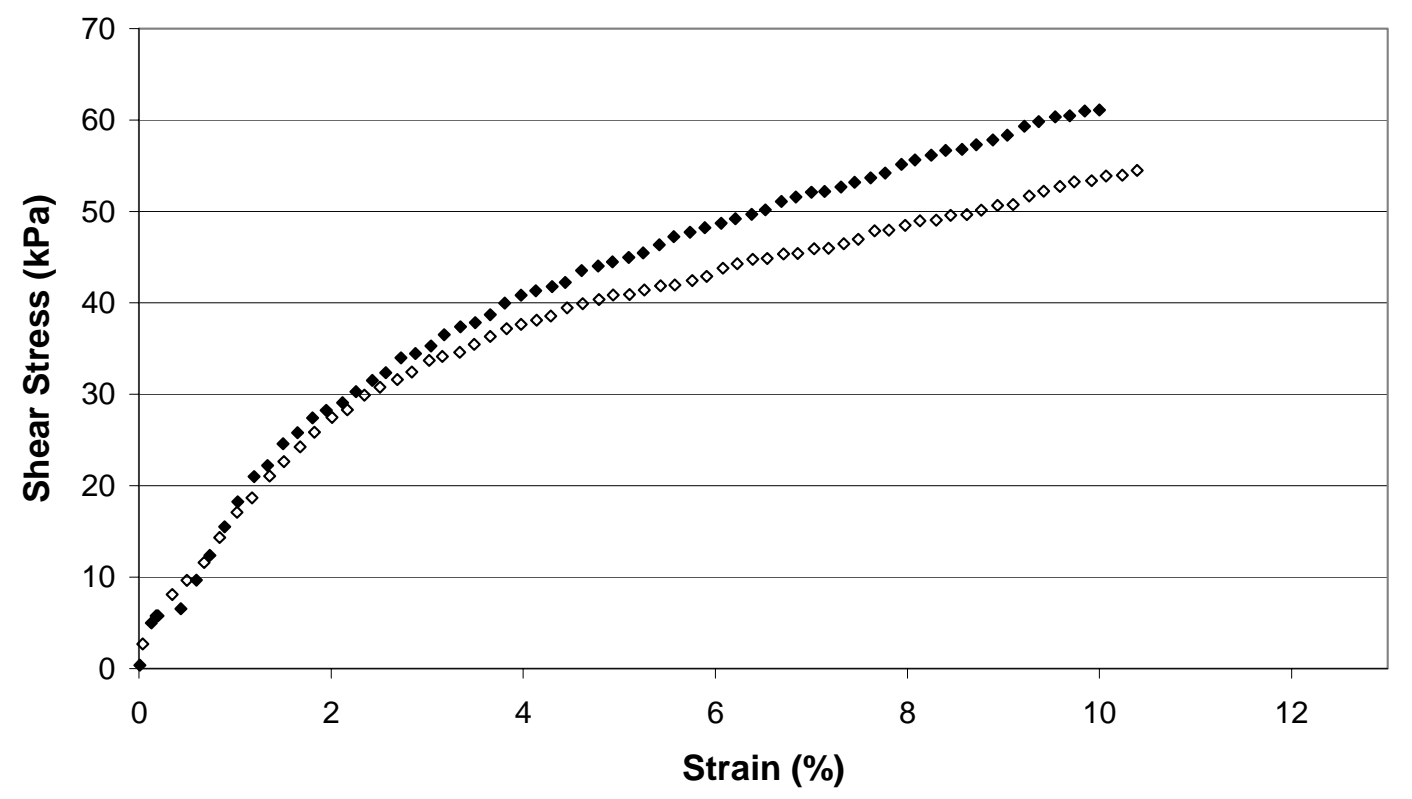

Figure 4.42: Direct shear test results for clay-clay interface at $\sigma_{\mathrm{n}}=69.6 \mathrm{kPa}$ with $10 \%$ water content. 


\section{DIRECT SHEAR RESULTS}

\section{Clay-Clay Interface, $10 \%$ water content, $S_{n}=103.9 \mathrm{kPa}$}

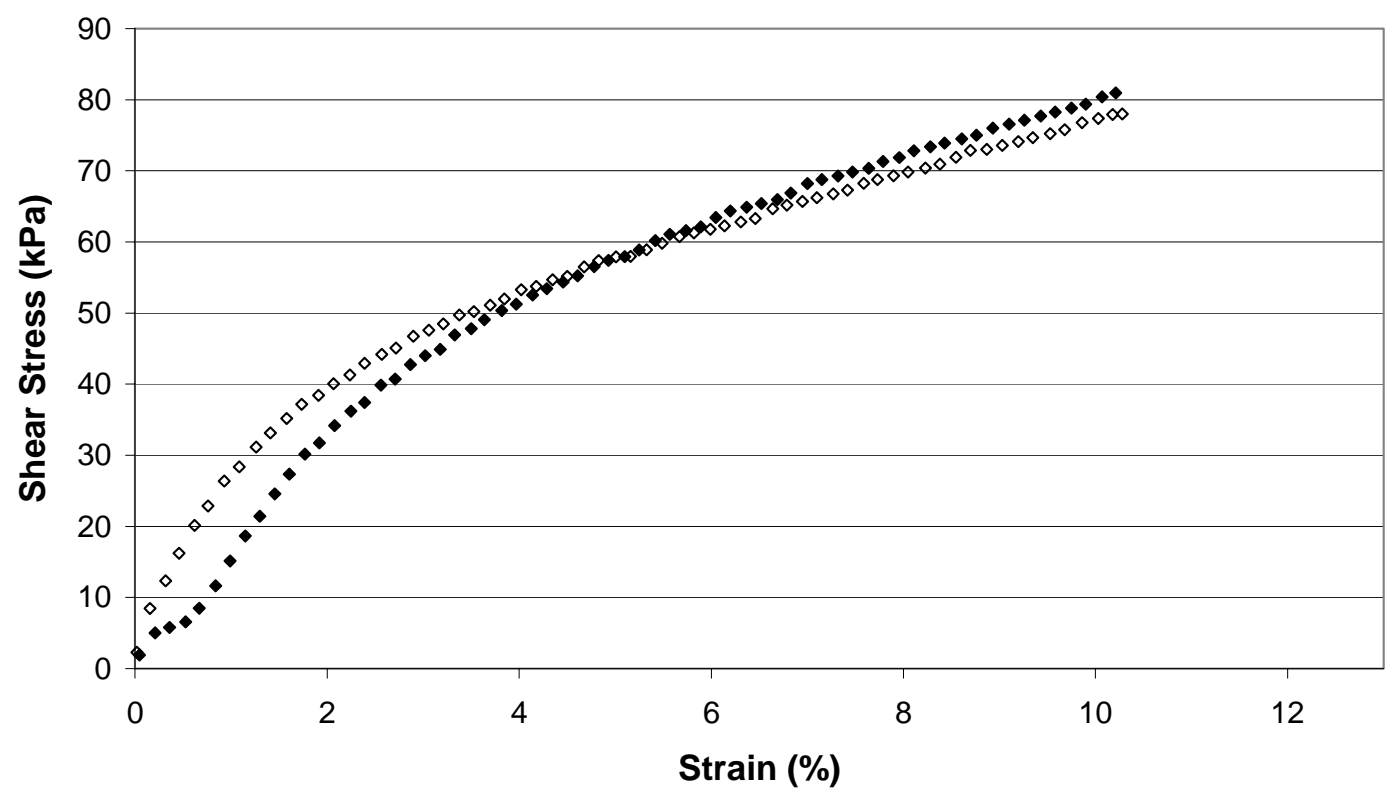

Figure 4.43: Direct shear test results for clay-clay interface at $\sigma_{\mathrm{n}}=103.9 \mathrm{kPa}$ with $10 \%$ water content. 
DIRECT SHEAR FAILURE ENVELOPE

Clay-Clay Interface, $10 \%$ water content

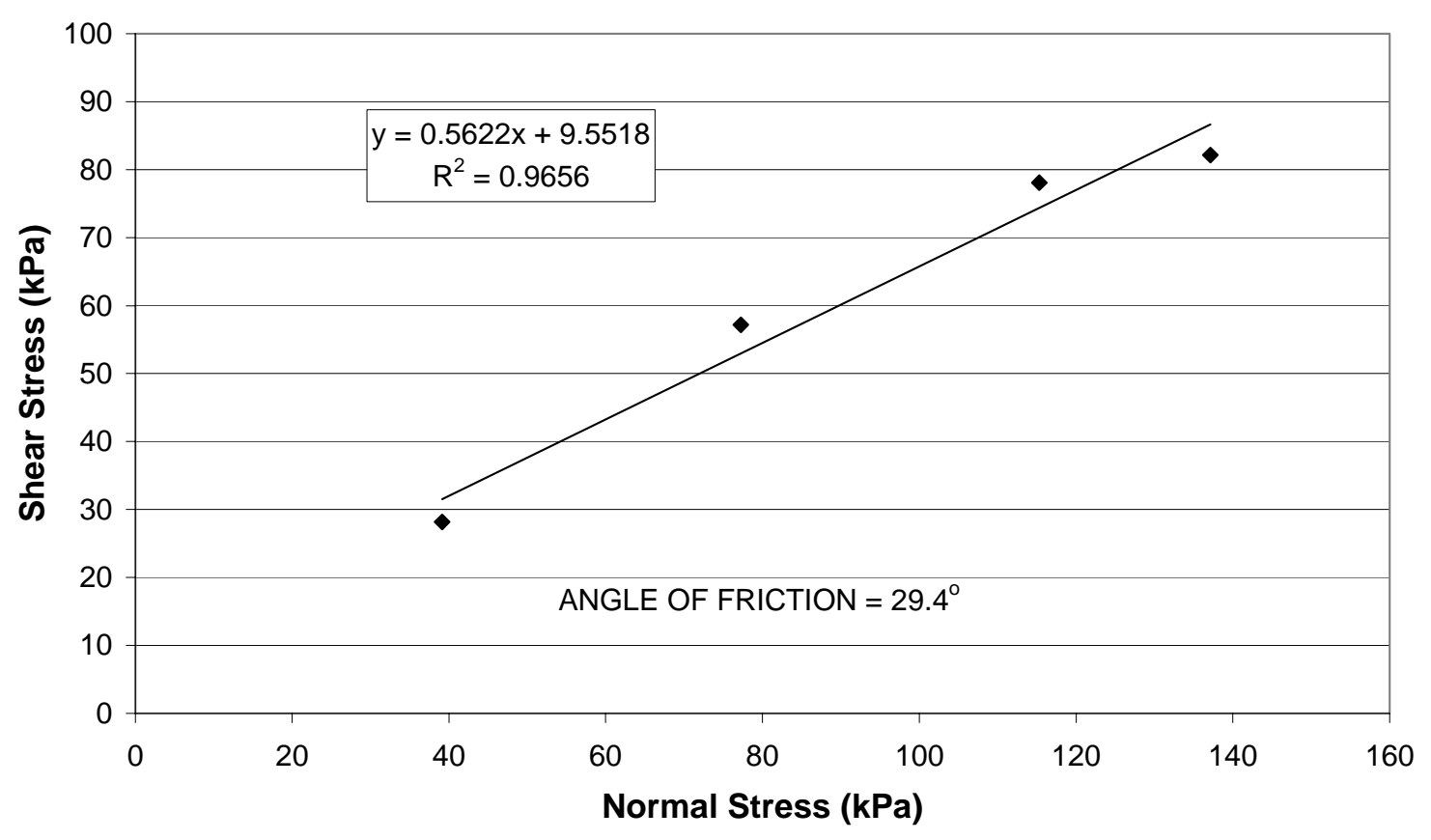

Figure 4.44: Direct shear failure envelope for clay-clay interface with $10 \%$ water content. 
Figures 4.45, 4.46 and 4.47 show the stress-strain relationship for material A-sand interface. Figure 4.48 shows the failure envelope for this interface. This failure envelope presents an angle of friction of 20.6 degrees and an effective cohesion of $3.5 \mathrm{kPa}$.

DIRECT SHEAR RESULTS

Clay-Clay Interface, $15 \%$ water content, $S_{n}=35.3 \mathrm{kPa}$

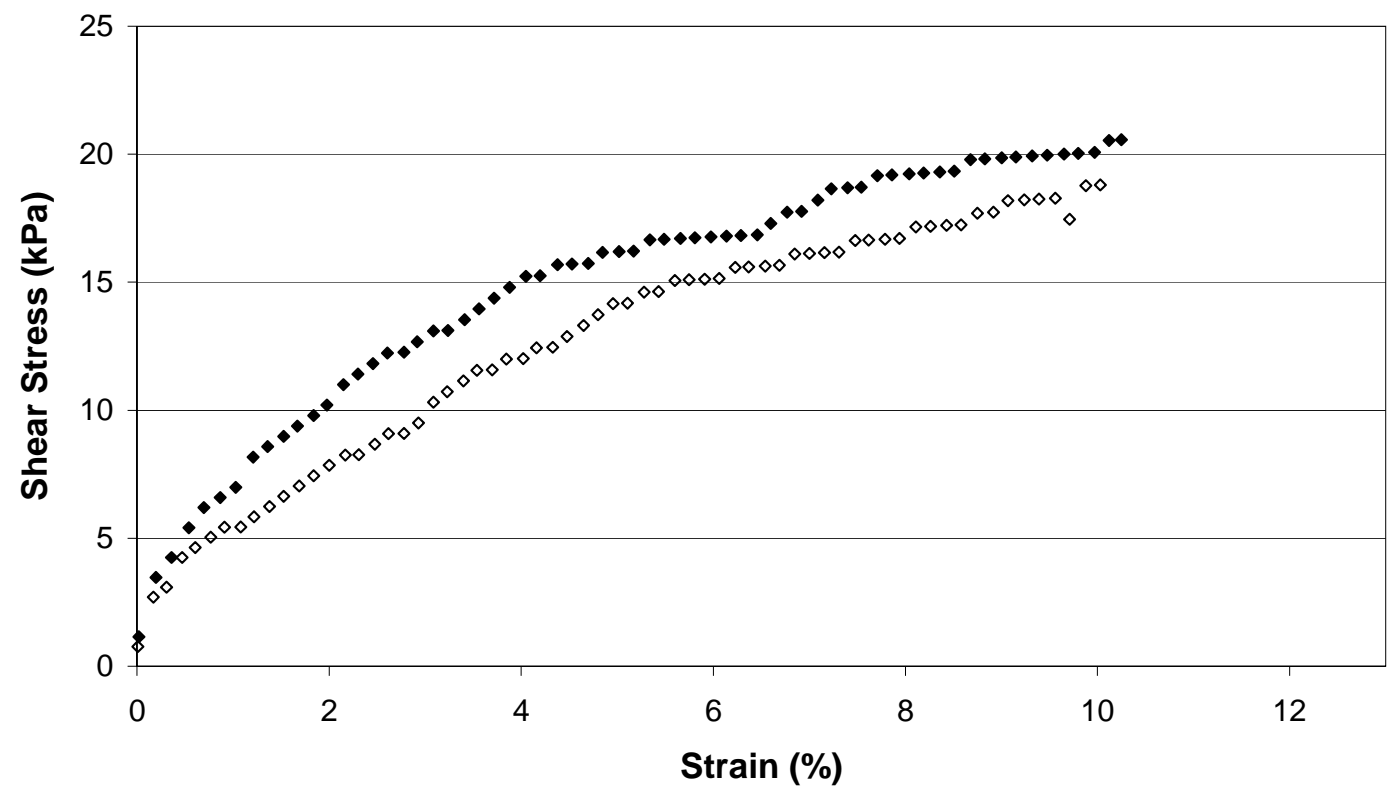

Figure 4.45: Direct shear test results for clay-clay interface at $\sigma_{\mathrm{n}}=35.3 \mathrm{kPa}$ with $15 \%$ water content. 


\section{DIRECT SHEAR RESULTS}

Clay-Clay Interface, $15 \%$ water content, $S_{n}=69.6 \mathrm{kPa}$

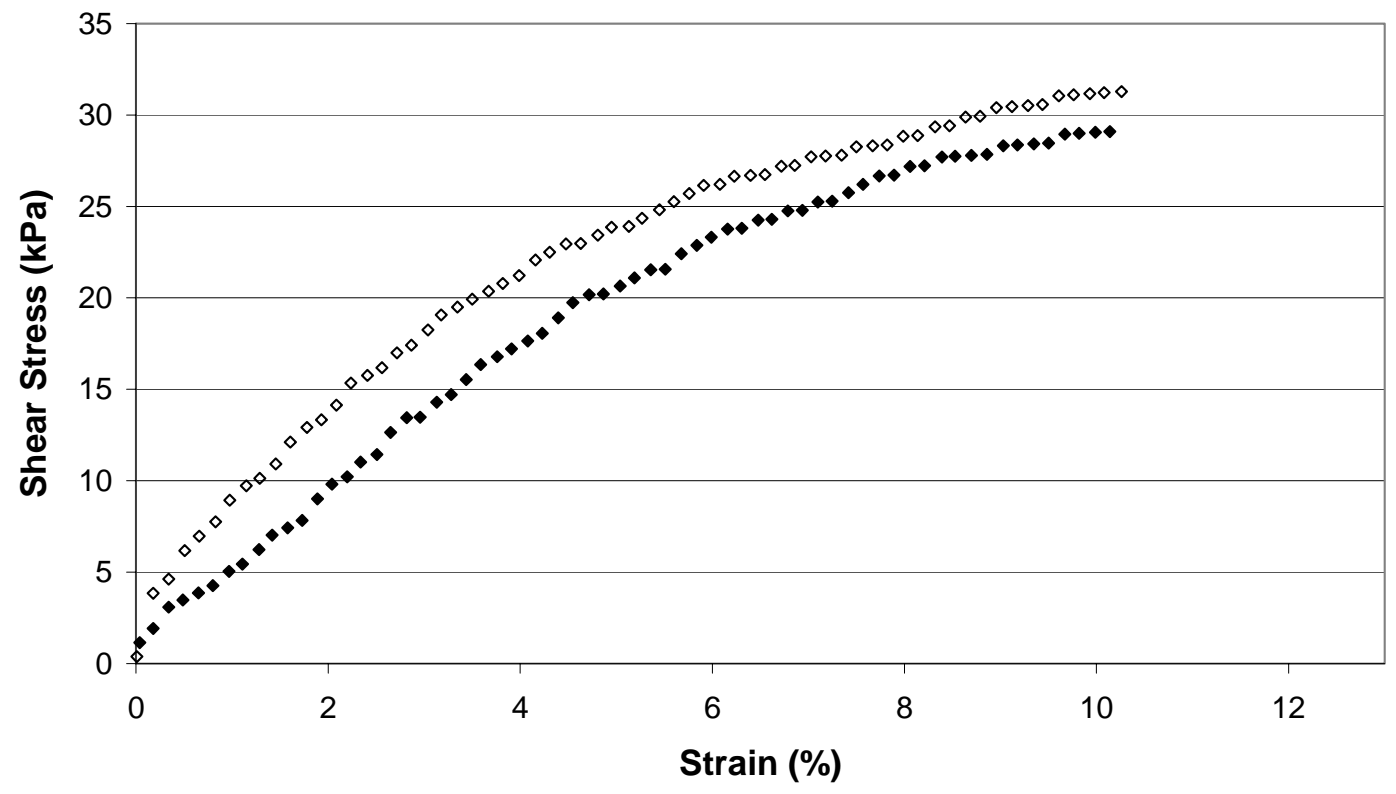

Figure 4.46: Direct shear test results for clay-clay interface at $\sigma_{\mathrm{n}}=69.6 \mathrm{kPa}$ with $15 \%$ water content. 
DIRECT SHEAR RESULTS

Clay-Clay Interface, $15 \%$ water content, $S_{n}=103.9 \mathrm{kPa}$

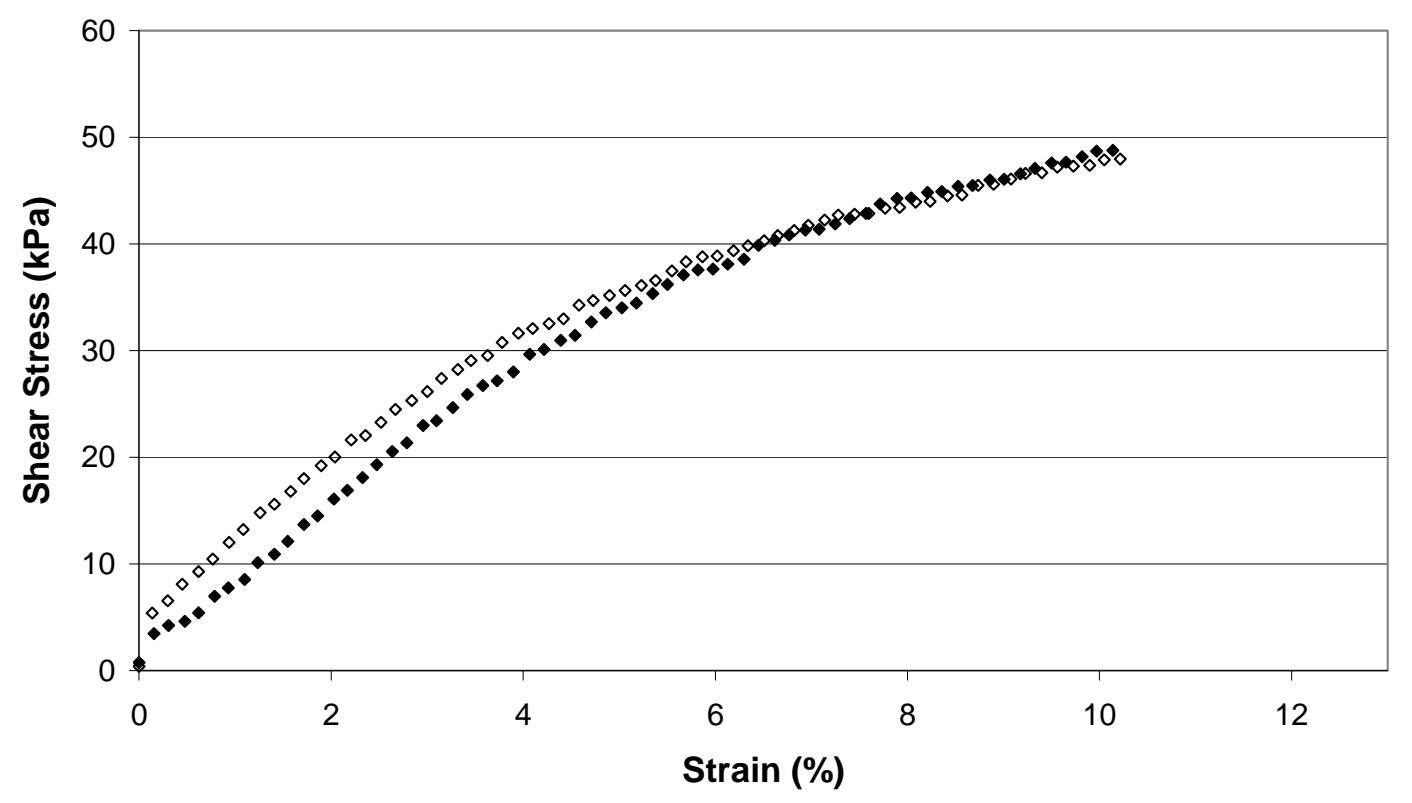

Figure 4.47: Direct shear test results for clay-clay interface at $\sigma_{\mathrm{n}}=103.9 \mathrm{kPa}$ with $15 \%$ water content. 
DIRECT SHEAR FAILURE ENVELOPE

Clay-Clay Interface, 15\% water content

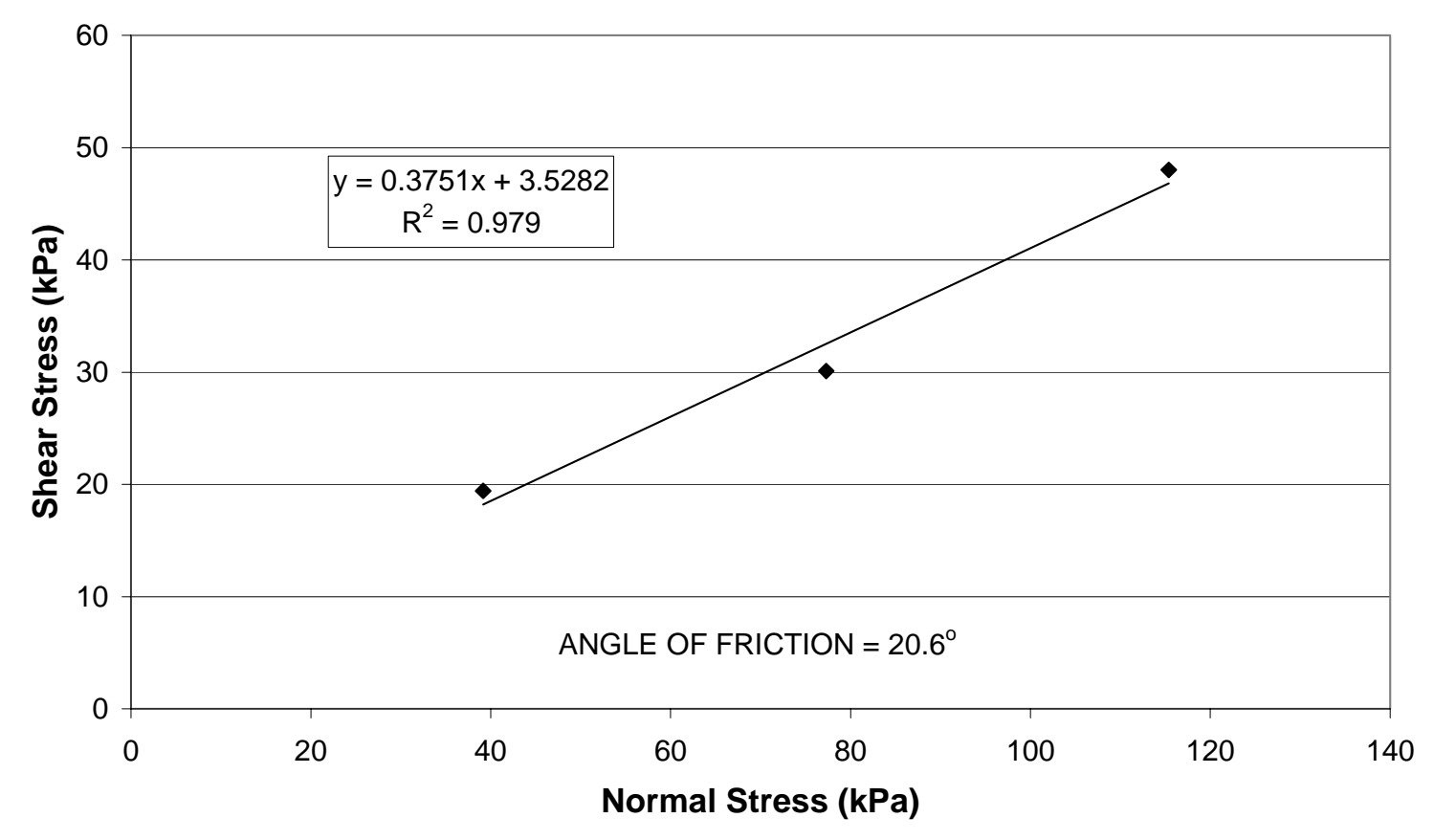

Figure 4.48: Direct shear failure envelope for clay-clay interface with $15 \%$ water content. 
Table 4.1 summarizes the angles of friction and effective cohesions from direct shear testing. This table also includes geosynthetic material properties used in direct shear testing. As you can see all effective cohesions are equal to zero for dry sand interfaces. The interface with the highest angle of friction was the clay-clay interface at $0 \%$ water content with an angle of friction equal to 31.7 degrees. The interface with the lowest angle of friction was the clay-clay interface at $15 \%$ water content with an angle of friction equal to 20.6 degrees.

Table 4.1: Summary of direct shear test results and geosynthetic material properties.

\begin{tabular}{|c|c|c|c|c|c|c|c|c|}
\hline $\begin{array}{c}\text { Geosynthetic } \\
\text { Material }\end{array}$ & $\begin{array}{c}\text { Tensile } \\
\text { Strength } \\
\text { (kN/m) }\end{array}$ & $\begin{array}{c}\text { Grid } \\
\text { Aperture } \\
\text { Size, MD } \\
(\mathrm{mm})\end{array}$ & $\begin{array}{c}\text { Grid } \\
\text { Aperture } \\
\text { Size, XMD } \\
\text { (mm) }\end{array}$ & $\begin{array}{c}\text { Mass per } \\
\text { Unit Area } \\
\left(\mathrm{g} / \mathrm{m}^{2}\right)\end{array}$ & $\begin{array}{l}\text { Soil } \\
\text { Type }\end{array}$ & $\begin{array}{c}\text { Water } \\
\text { Content } \\
(\%)\end{array}$ & $\begin{array}{l}\text { Angle of } \\
\text { Friction } \\
\text { (degrees) }\end{array}$ & $\begin{array}{c}\text { Effective } \\
\text { Cohesion } \\
\quad(\mathrm{kPa})\end{array}$ \\
\hline $\mathrm{A}$ & 120 & 65 & 20 & 415 & Sand & 0 & 25.4 & 0 \\
\hline $\mathrm{B}$ & 35 & 40 & 25 & 170 & Sand & 0 & 31.5 & 0 \\
\hline C & 0.36 & $\mathrm{~N} / \mathrm{A}$ & $\mathrm{N} / \mathrm{A}$ & $310 *$ & Sand & 0 & 29.5 & 0 \\
\hline \multirow{3}{*}{\multicolumn{6}{|c|}{ Sand-Sand Interface }} & 0 & 26.7 & 0 \\
\hline & & & & & & 10 & 24.1 & 5.5 \\
\hline & & & & & & 15 & 23.1 & 5.6 \\
\hline \multirow{3}{*}{\multicolumn{6}{|c|}{ Silt-Silt Interface }} & 0 & 30.2 & 0.6 \\
\hline & & & & & & 10 & 26.2 & 4.9 \\
\hline & & & & & & 15 & 22.3 & 12.2 \\
\hline \multirow{3}{*}{\multicolumn{6}{|c|}{ Clay-Clay Interface }} & 0 & 31.7 & 2.9 \\
\hline & & & & & & 10 & 29.4 & 9.6 \\
\hline & & & & & & 15 & 20.6 & 3.5 \\
\hline
\end{tabular}

*Value was calculated in laboratory. 


\subsection{Effects of Geosynthetic Material Properties on Direct Shear Tests Results}

Figures 4.49, 4.50 and 4.51 show the direct shear test results for all geosyntheticsand interfaces at different normal pressures. Material A has the highest tensile strength but the lowest shear stress failure values. Material B has the second highest tensile strength and the highest shear stress failure values. This shows that when considering all geosynthetics used in this study tensile strength has no effect on the direct shear stress failure values. However, if only the two geogrids are considered (material A and material B) the results show that the geogrid with lower tensile strength (material B) has consistently higher shear stress failure values than the geogrid with higher tensile strength (material A).

\section{DIRECT SHEAR TEST RESULTS \\ Geosynthetic-Sand Interface, $S_{n}=103.9 \mathrm{kPa}$}

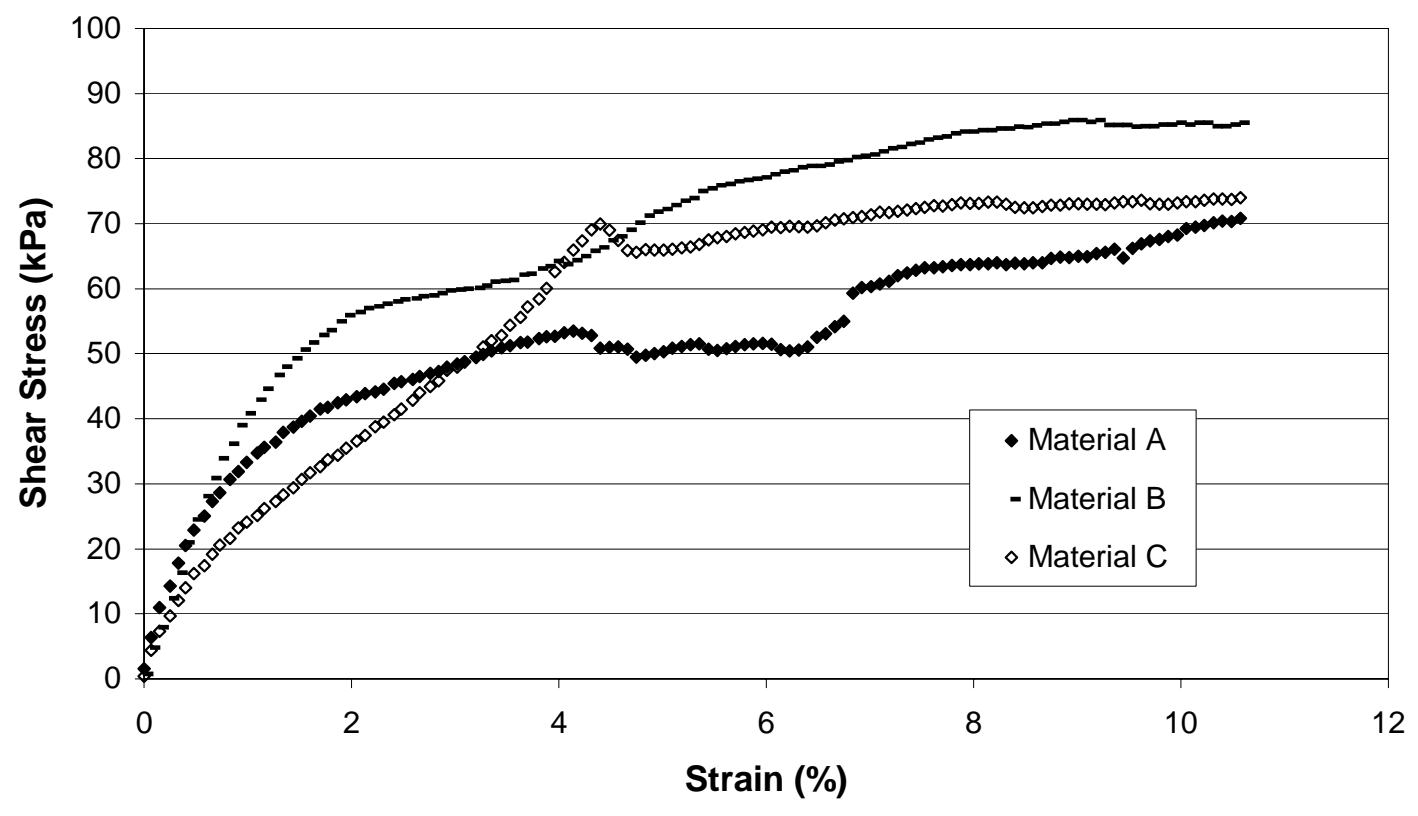

Figure 4.49: Direct shear test results for material $A, B$, and C-sand interface at $S_{n}=35.3 \mathrm{kPa}$ 


\section{DIRECT SHEAR TEST RESULTS \\ Geosynthetic-Sand Interface, $S_{n}=69.6 \mathrm{kPa}$}

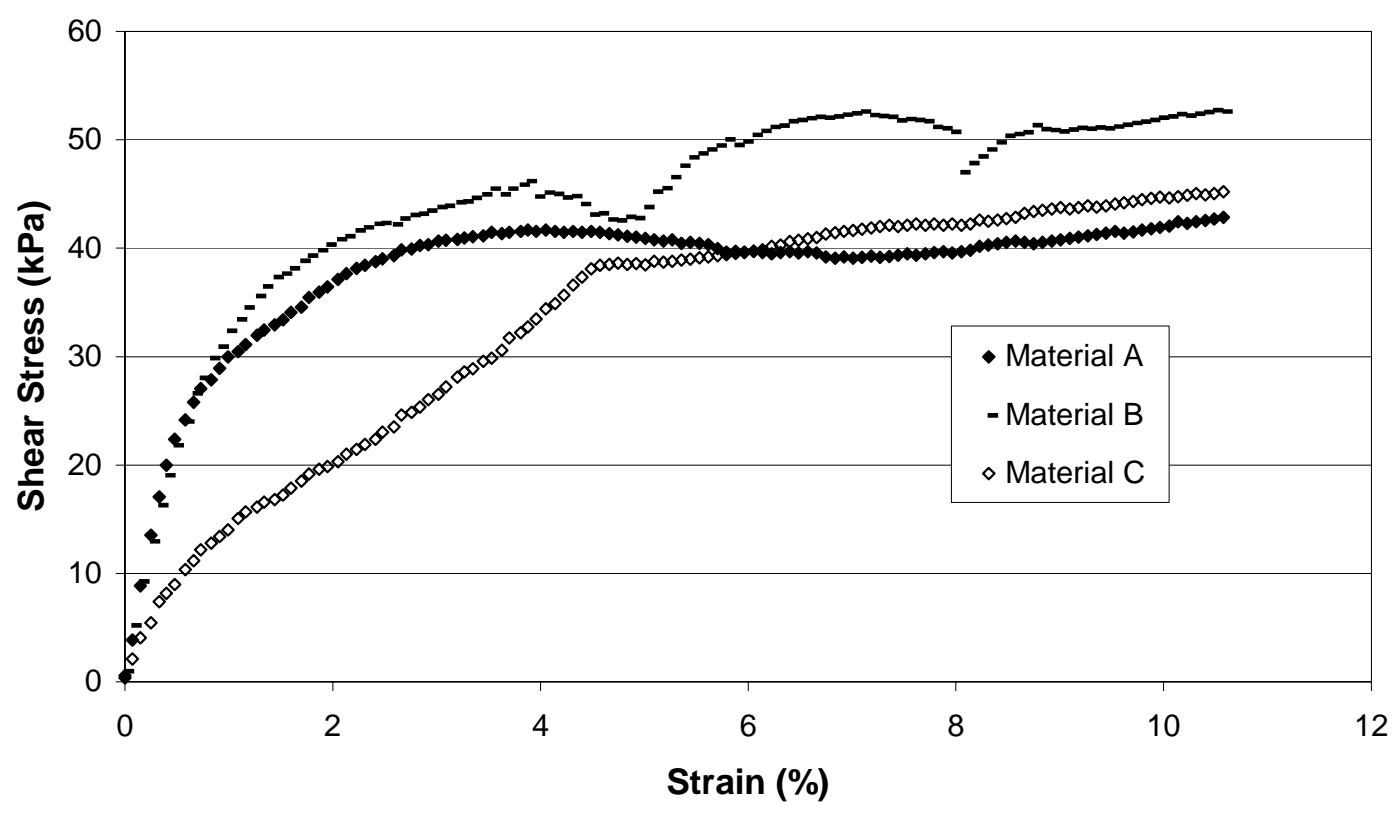

Figure 4.50: Direct shear test results for material A, B, and C-sand interface at $S_{n}=69.6 \mathrm{kPa}$ 


\section{DIRECT SHEAR TEST RESULTS \\ Geosynthetic-Sand Interface, $S_{n}=103.9 \mathrm{kPa}$}

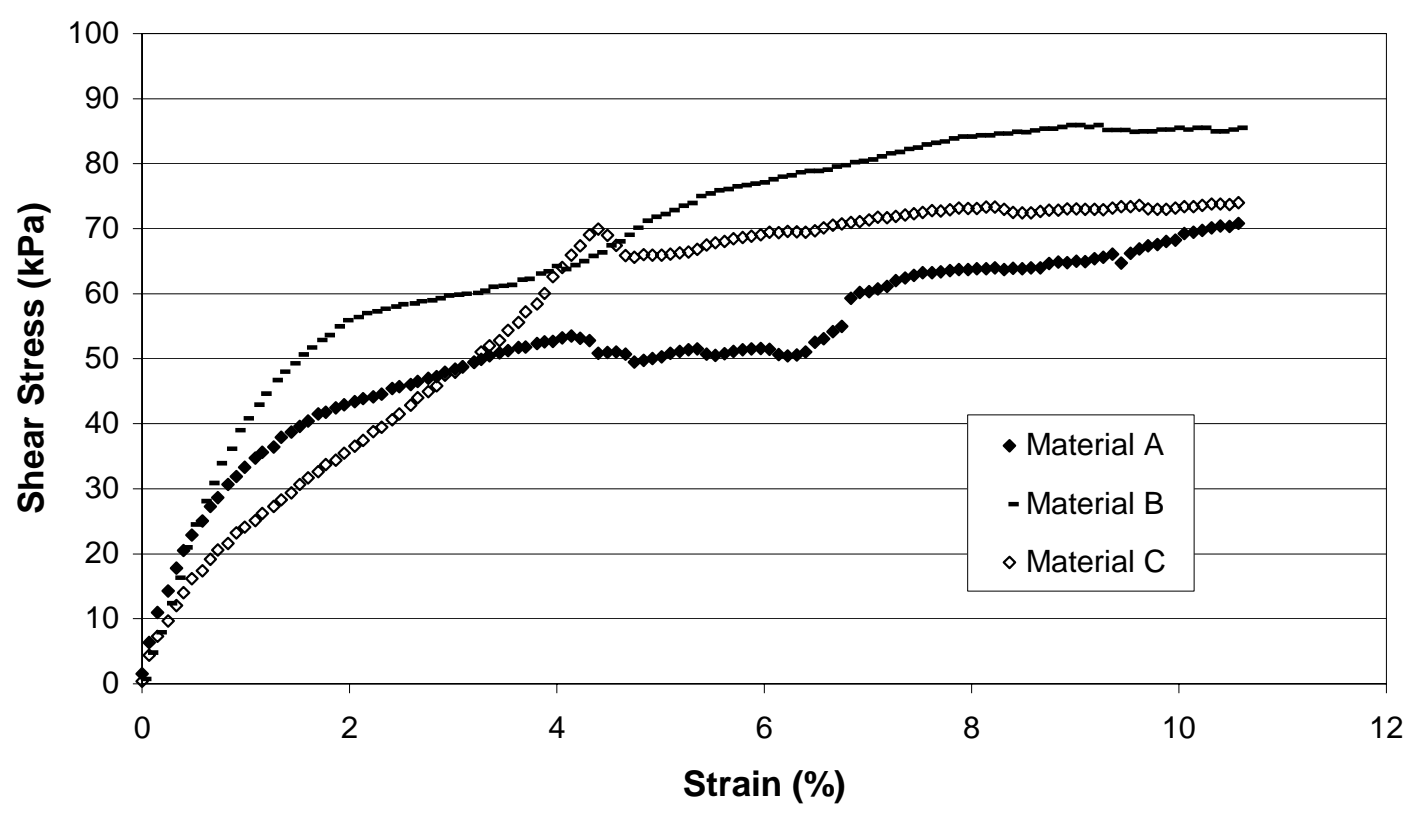

Figure 4.51: Direct shear test results for material A, B, and C-sand interface at $S_{n}=103.9 \mathrm{kPa}$ 


\subsection{Pullout Box A Test Results and Discussion}

Pullout tests were preformed at three different normal stresses; $34.5 \mathrm{kPa}$ (5 psi), 69 $\mathrm{kPa}(10 \mathrm{psi})$ and $103.4 \mathrm{kPa}$ (15 psi). The airbags discussed in chapter two were used to apply these normal stresses. At least two tests were run for each specimen configuration. This was done to assure repeatable results and to identify any errors in the testing. Three geosynthetics were used in pullout testing. The first was a geogrid referred to as material A. The second was also a geogrid and is referred to as material B. The third and final geosynthetic was a geotextile referred to as material C. All geosynthetic properties can be found in Table 3.1. Three soils were also tested in conjunction with the three geosynthetics: sand, silt and clay. When using silt and clay three different water contents were tested; $0 \%, 10 \%$, and $15 \%$. The results and discussions are presented in this section.

Figure 4.52, 4.53, and 4.54 shows the pullout shear stress-strain relationships for the interface consisting of material A and sand. The pullout failure envelope for this interface is shown in Figure 4.55. This figure illustrates an angle of friction equal to 26.01 degrees and an effective cohesion of zero. The trend line, which was placed in this figure, was forced through the origin of the graph. This was done because sand has no effective cohesion. 


\section{PULLOUT STRESS-STRAIN RELATIONSHIP}

Material A-Sand Interface, $S_{n}=34.5 \mathrm{kPa}$

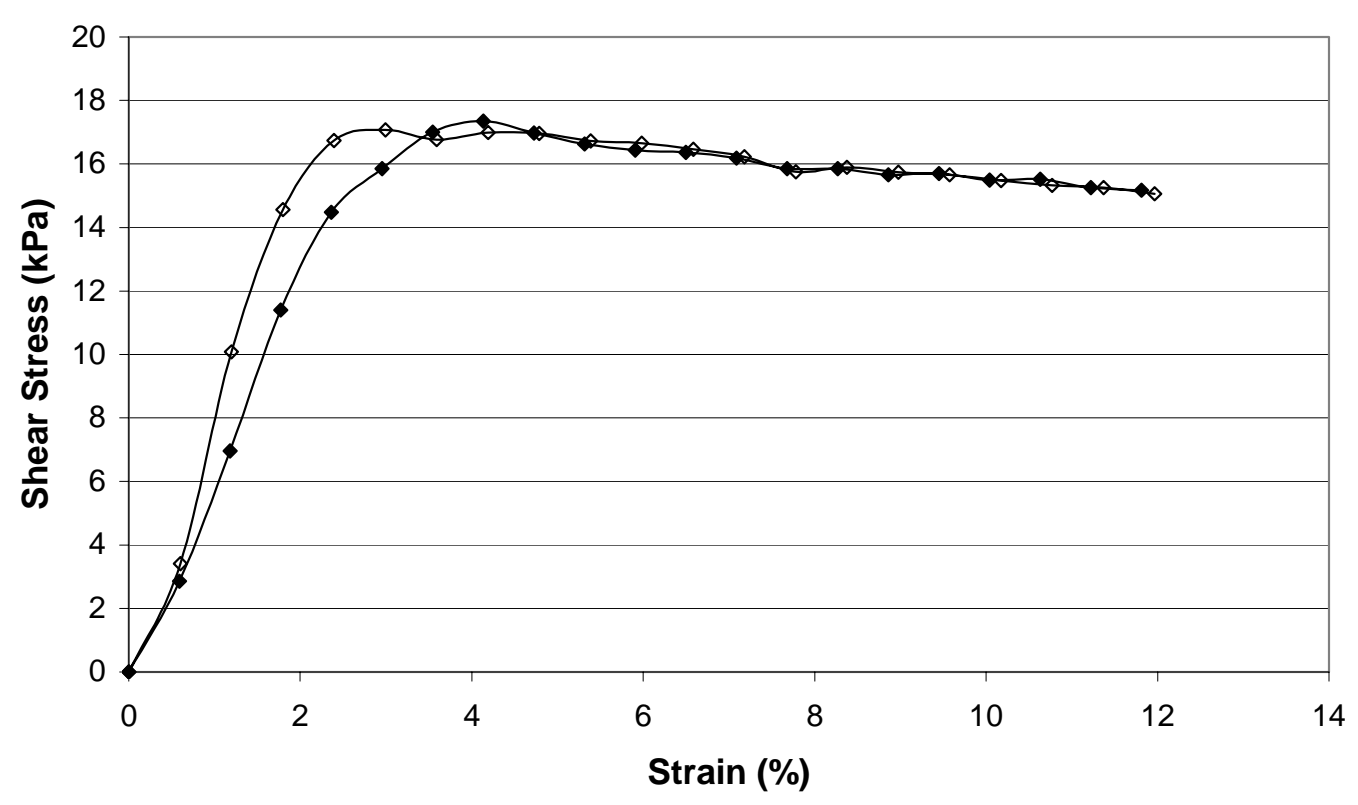

Figure 4.52: Pullout test results for material A-sand interface at $S_{n}=103.4 \mathrm{kPa}$. 
PULLOUT STRESS-STRAIN RELATIONSHIP Material A-Sand Interface, $S_{n}=69 \mathrm{kPa}$

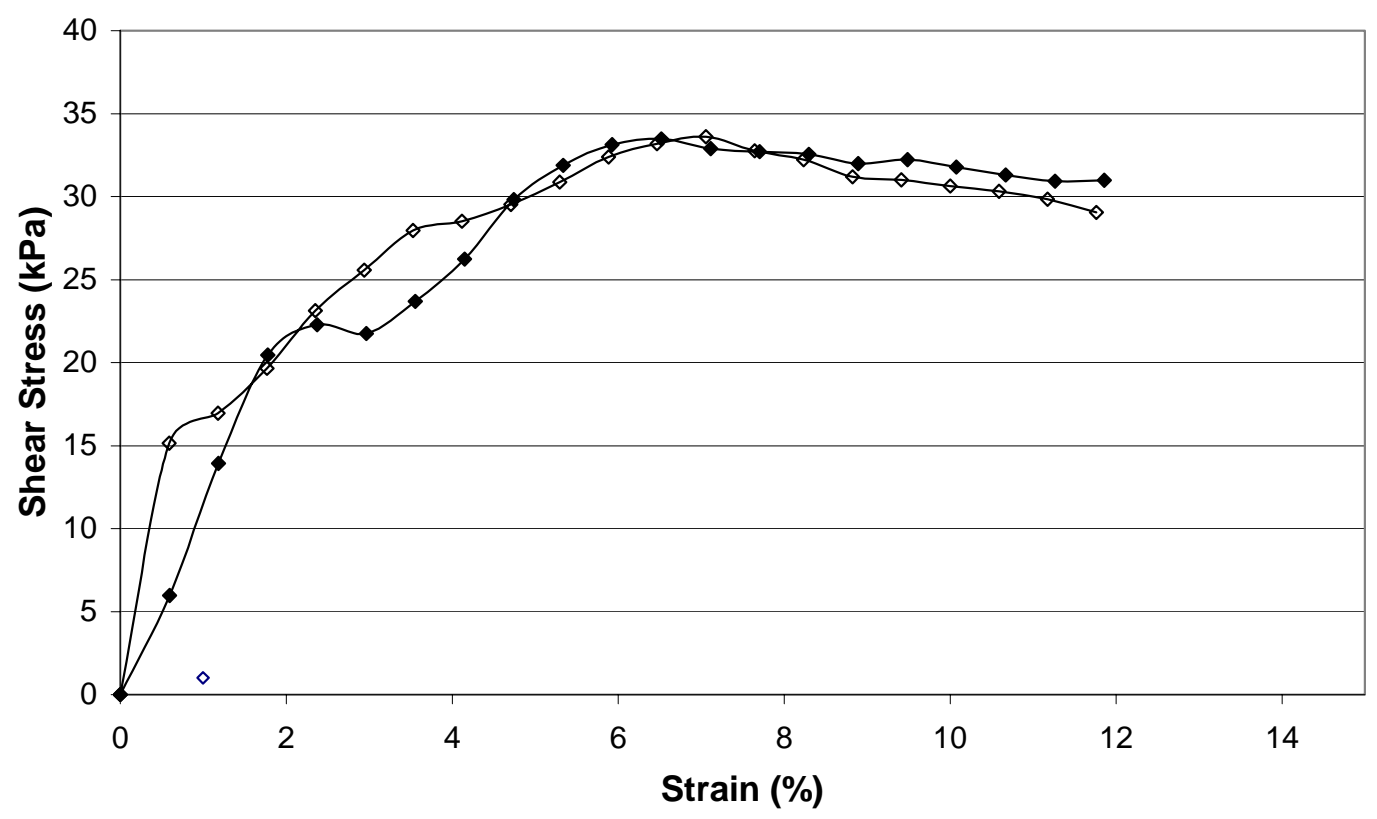

Figure 4.53: Pullout test results for material A-sand interface at $S_{n}=69 \mathrm{kPa}$. 
PULLOUT STRESS-STRAIN RELATIONSHIP

Material A-Sand Interface, $S_{n}=103.4 \mathrm{kPa}$

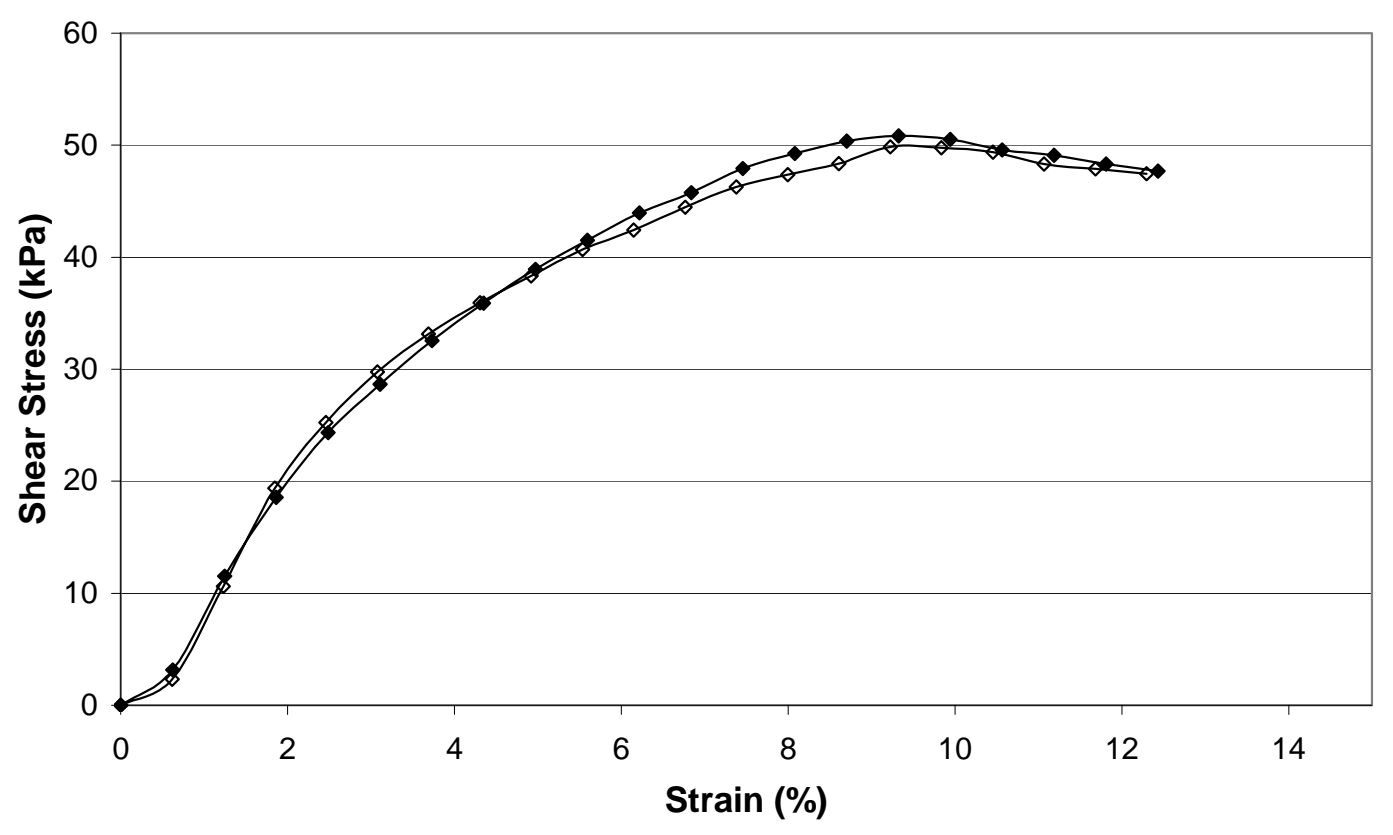

Figure 4.54: Pullout test results for material A-sand interface at $S_{n}=103.4 \mathrm{kPa}$. 


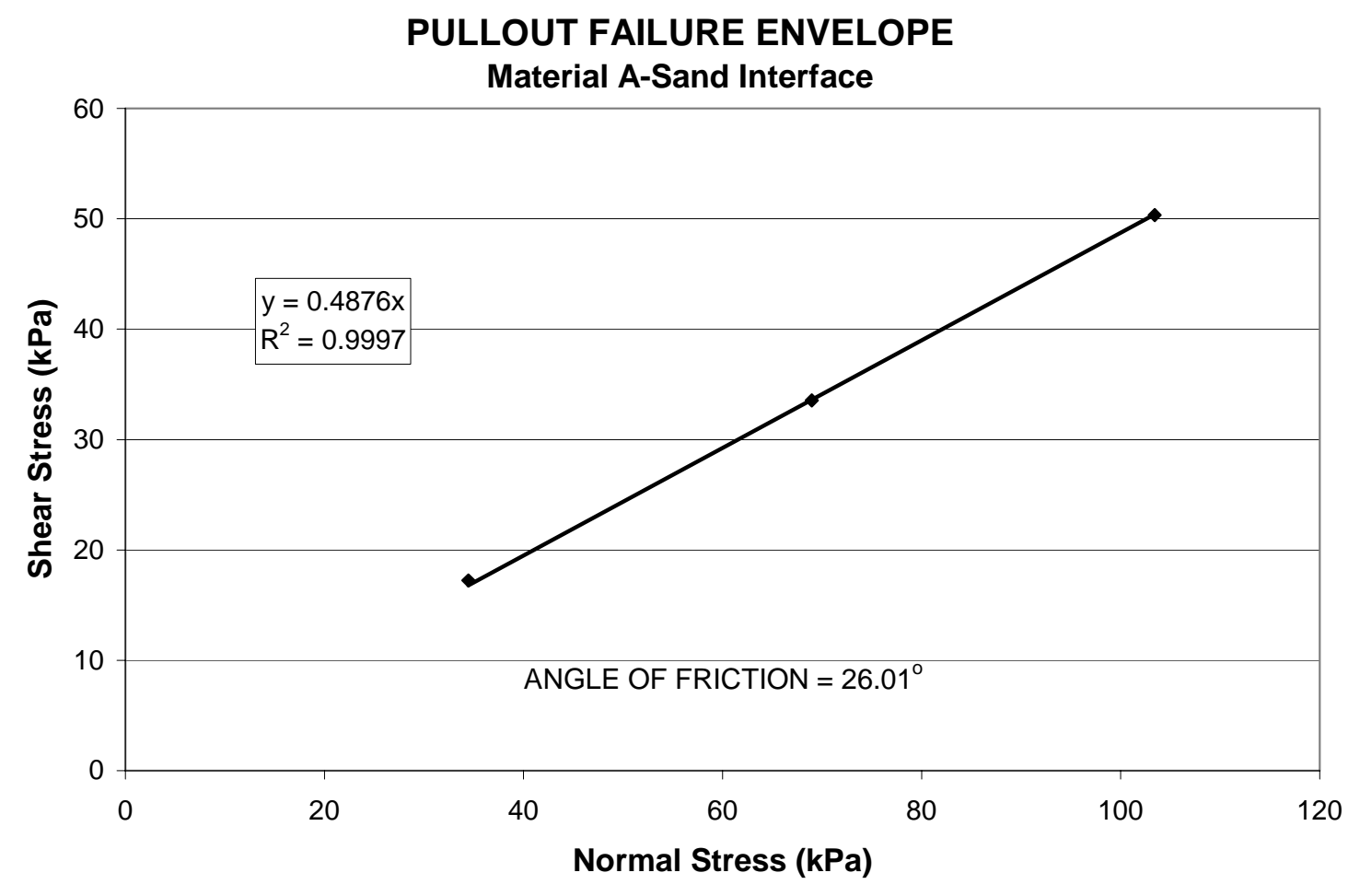

Figure 4.55: Pullout failure envelope for material A - sand interface. 
Figures 4.56, 4.57 and 4.58 show the pullout stress-strain relationship for material B-sand interface. Figure 4.59 illustrates the failure envelope for this interface. An angle of friction equal to 12.21 degrees and an effective cohesion equal to zero was recorded. The trend line, which was placed in Figure 4.59, was forced through the origin of the graph. This was done because sand has no effective cohesion. Stretching of material B occurred during pullout testing because of its low tensile strength. This resulted in similar shear stress values at failure for all normal stresses.

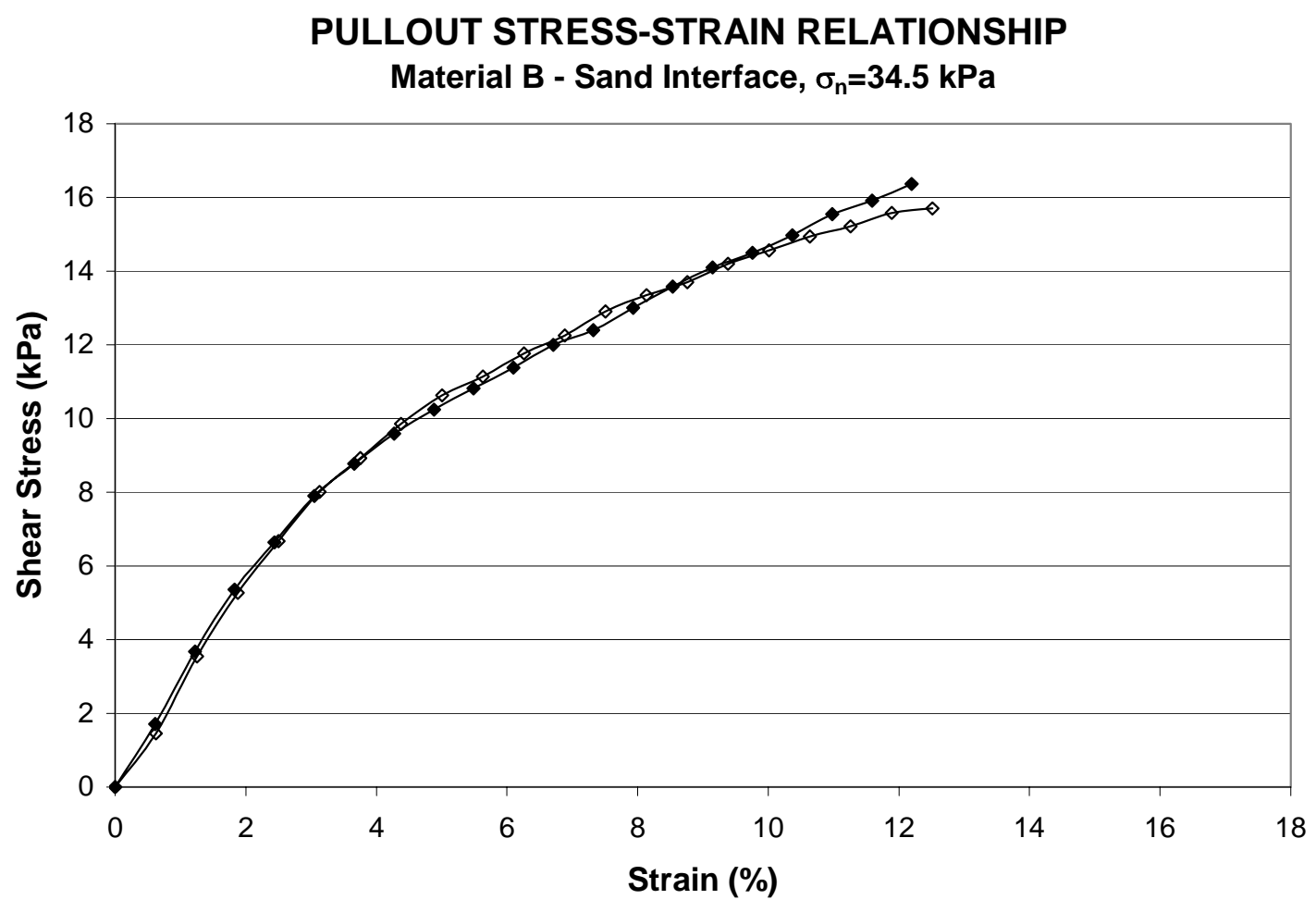

Figure 4.56: Pullout test results for material B-sand interface at $S_{n}=34.5 \mathrm{kPa}$. 


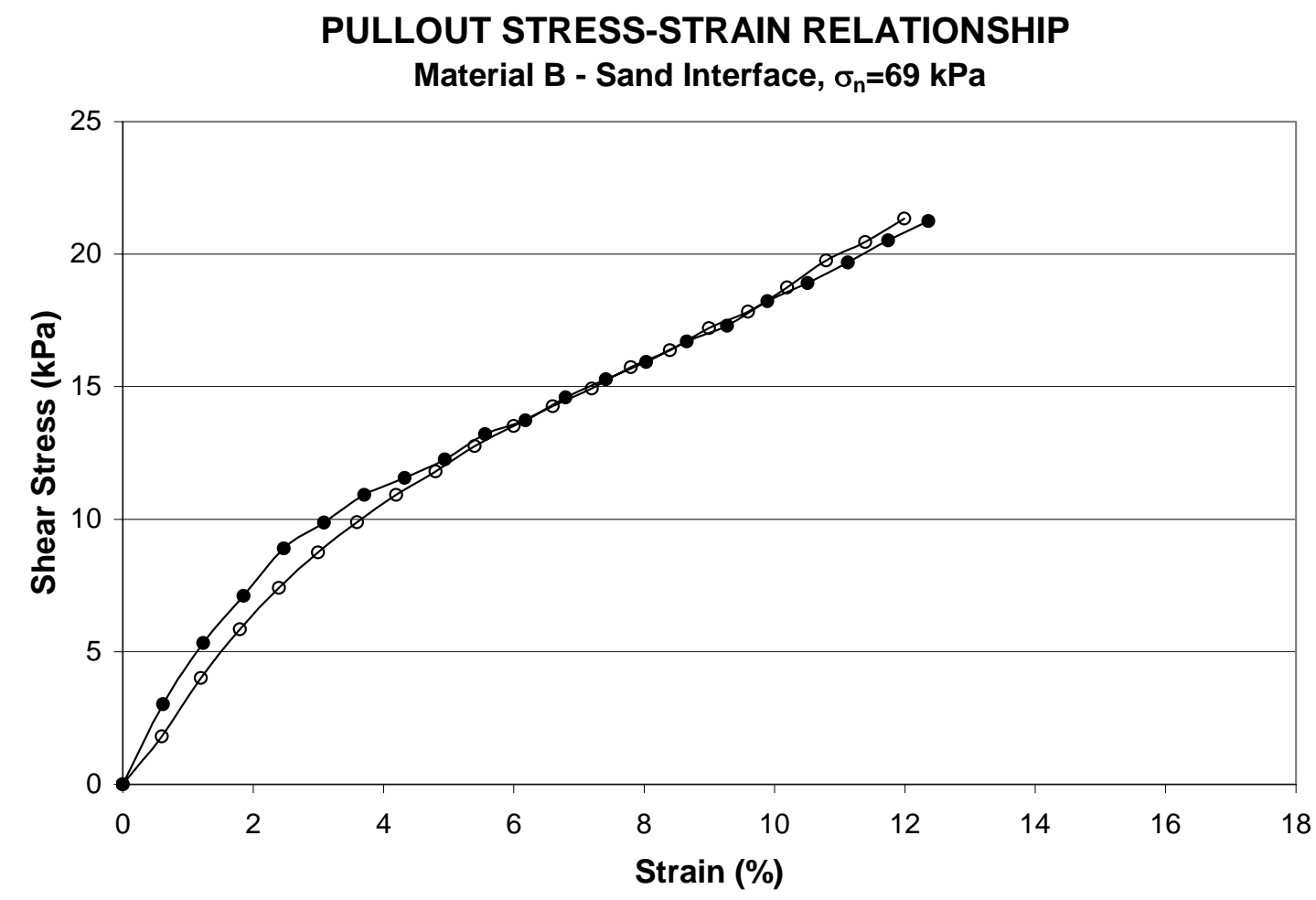

Figure 4.57: Pullout test results for material B-sand interface at $S_{n}=69 \mathrm{kPa}$. 


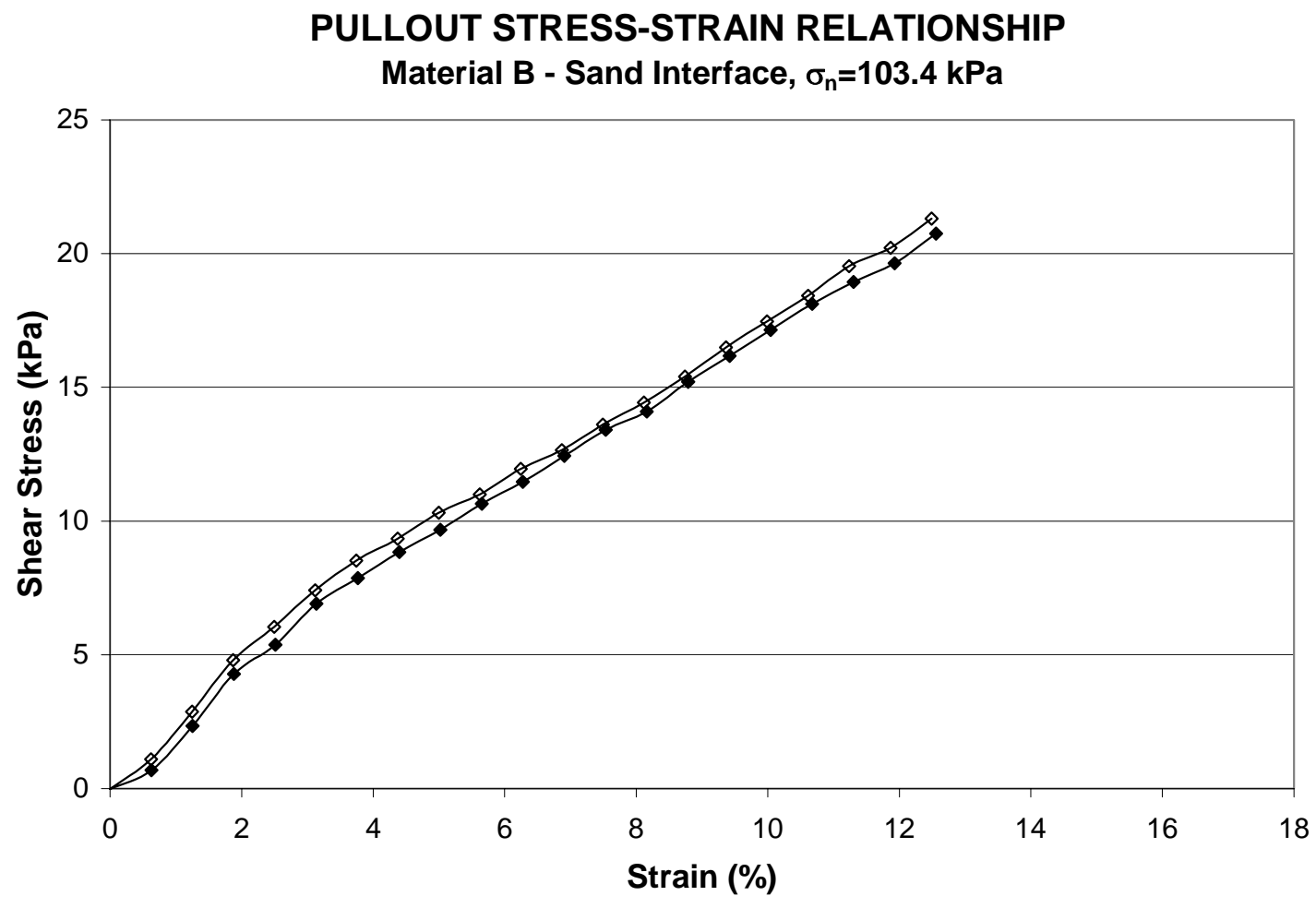

Figure 4.58: Pullout test results for material B-sand interface at $S_{n}=103.4 \mathrm{kPa}$. 


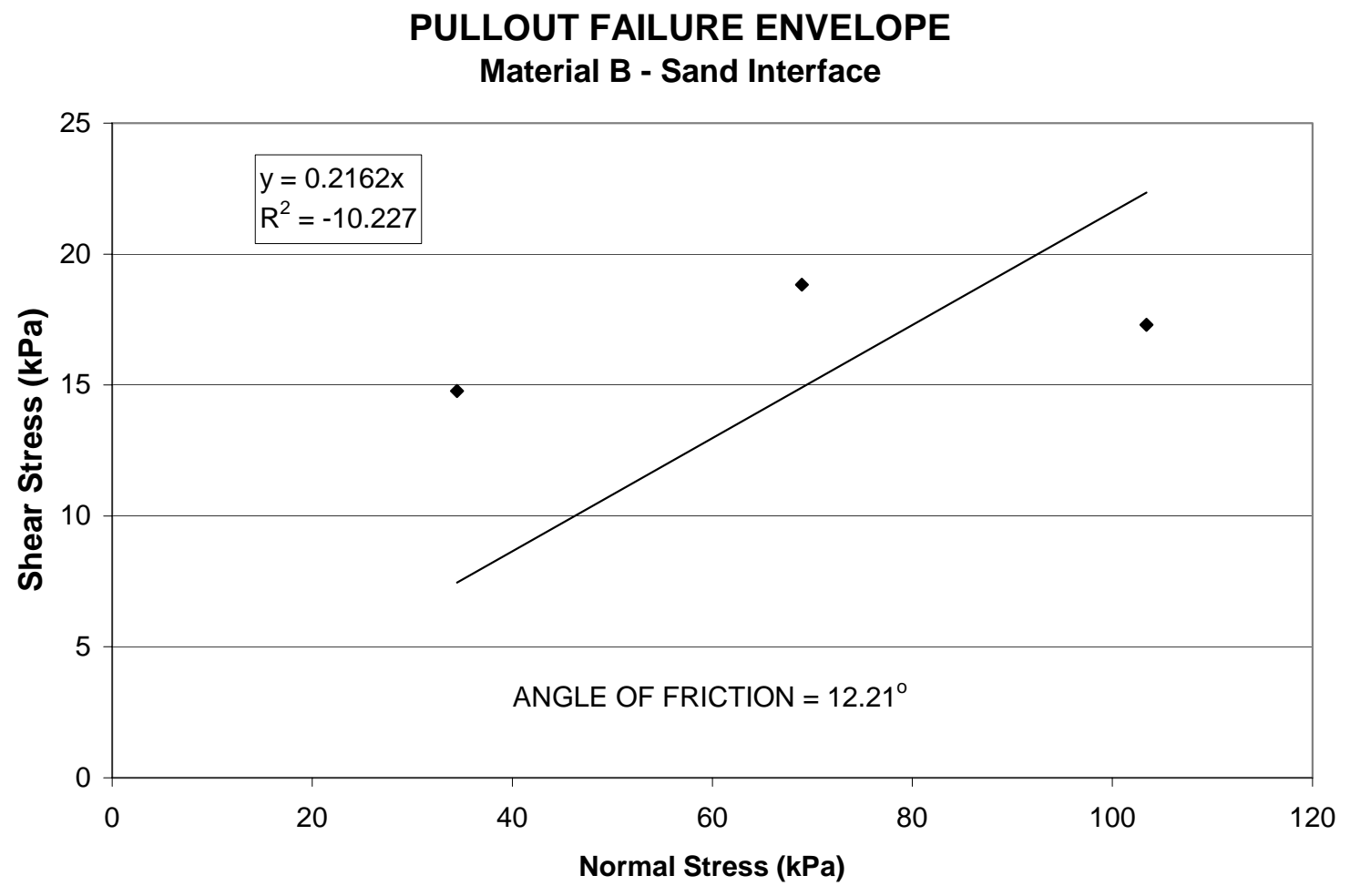

Figure 4.59: Pullout failure envelope for material B - sand interface. 
In the following three figures, Figure 4.60, 4.61 and 4.62, the pullout stress-strain relationship for material C-sand is presented. An angle of friction equal to 2.11 degrees is shown in Figure 4.63. This figure illustrates the failure envelope for the interface and shows an effective cohesion of zero. A trend line was placed in Figure 4.63 and forced through the origin of the graph. This was done because sand has no effective cohesion. Stretching of material B occurred during pullout testing because of its low tensile strength. This resulted in similar shear stress values at failure for all normal stresses.

PULLOUT STRESS-STRAIN RELATIONSHIP

MATERIAL C-Sand Interface, $\mathrm{S}_{\mathrm{n}}=34.5 \mathrm{kPa}$

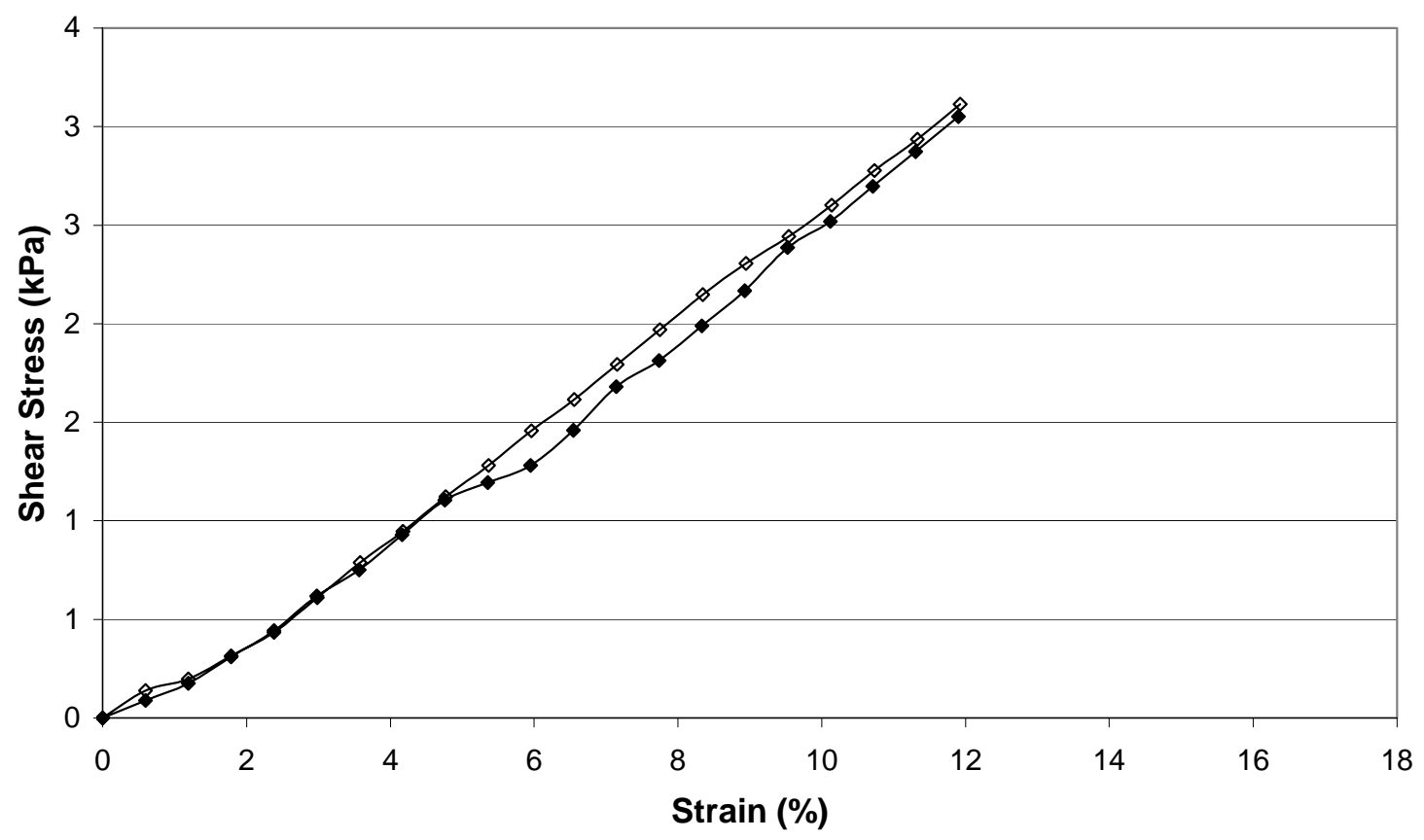

Figure 4.60: Pullout test results for material $\mathrm{C}$ - sand interface at $S_{\mathrm{n}}=34.5 \mathrm{kPa}$. 
PULLOUT STRESS-STRAIN RELATIONSHIP

MATERIAL C-Sand Interface, $S_{n}=69 \mathrm{kPa}$

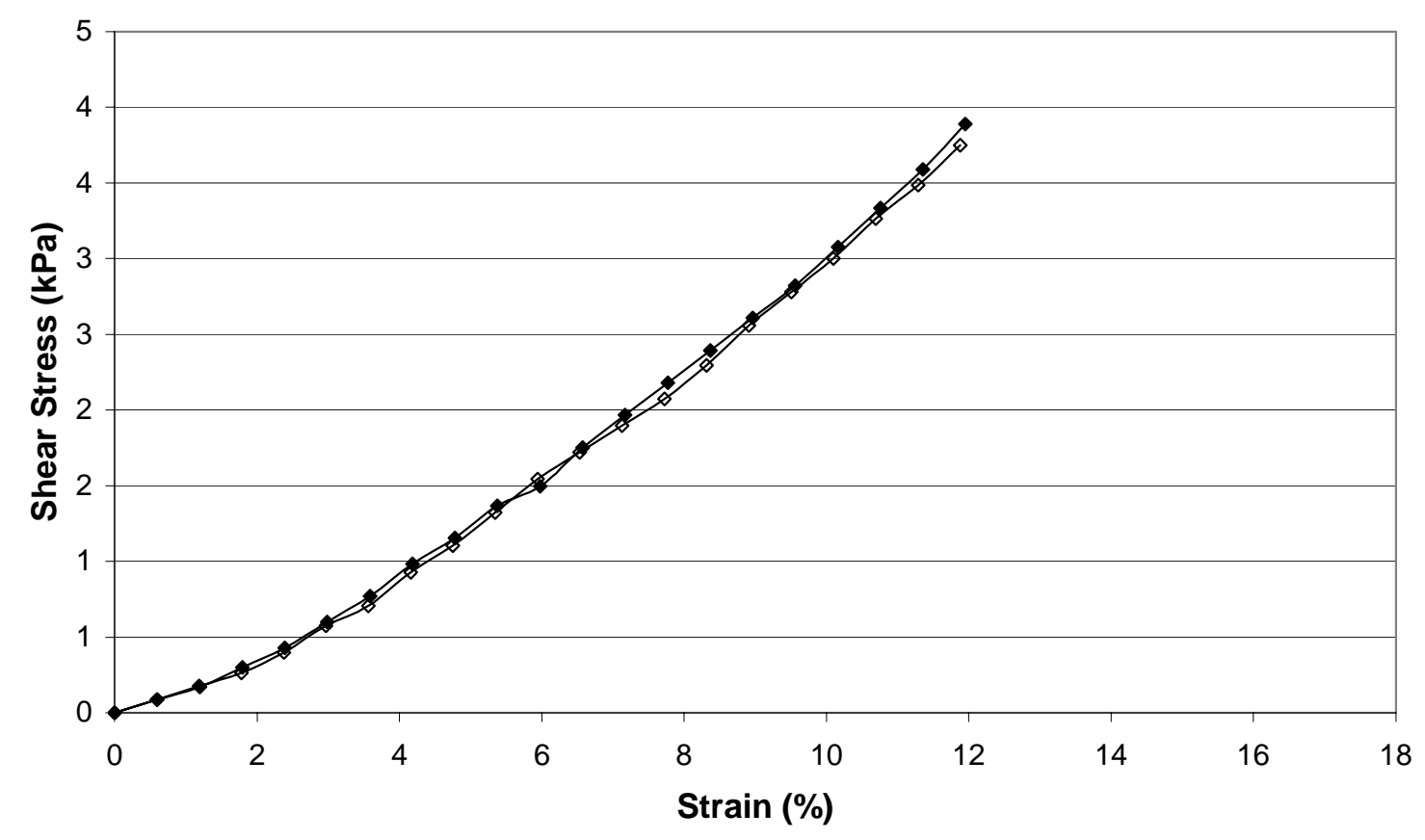

Figure 4.61: Pullout test results for material C - sand interface at $S_{n}=69 \mathrm{kPa}$. 
PULLOUT STRESS-STRAIN RELATIONSHIP MATERIAL C-Sand Interface, $S_{n}=103.4 \mathrm{kPa}$

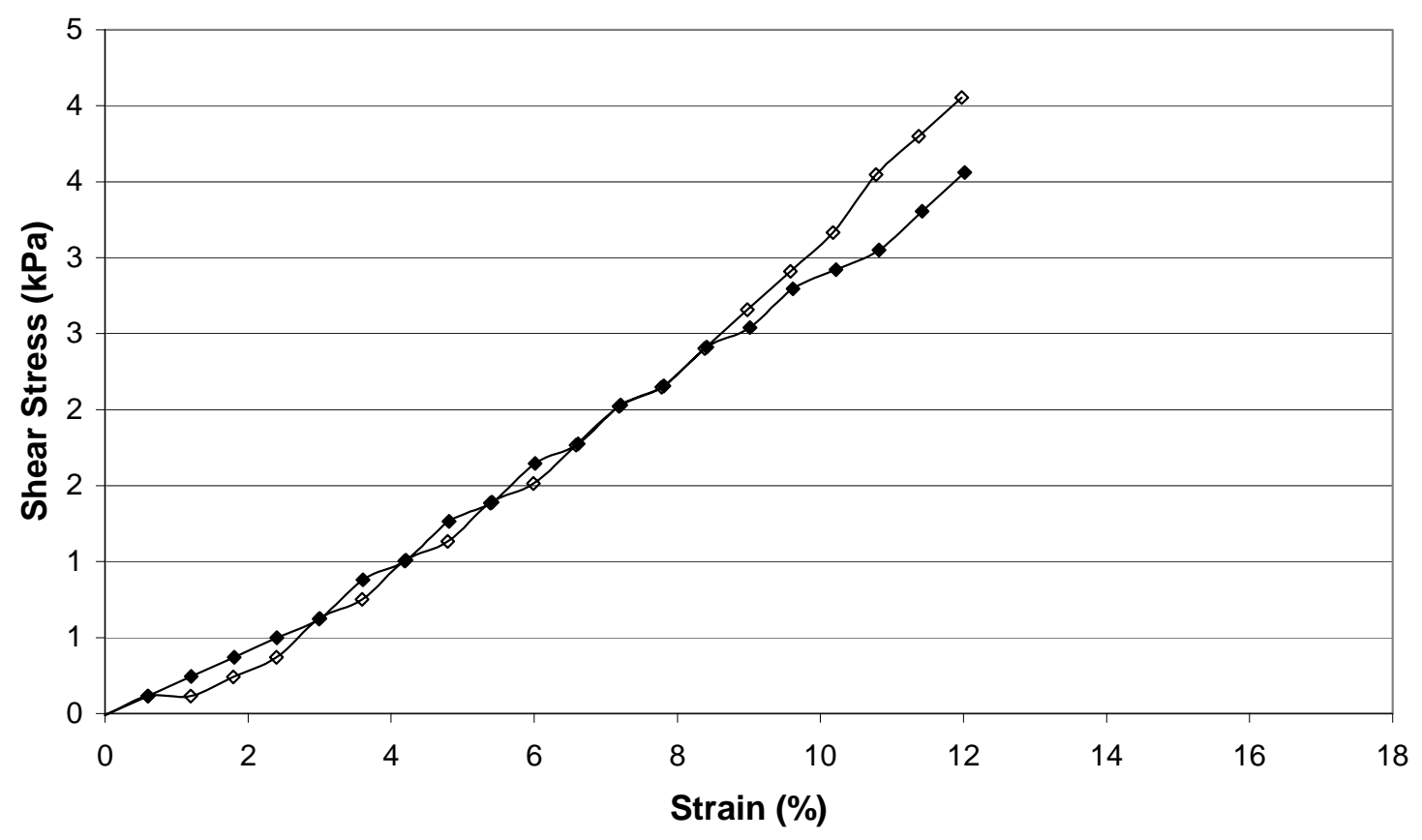

Figure 4.62: Pullout test results for material C - sand interface at $\sigma_{\mathrm{n}}=\mathbf{1 0 3 . 4} \mathrm{kPa}$. 


\section{PULLOUT FAILURE ENVELOPE MATERIAL C-Sand Interface}

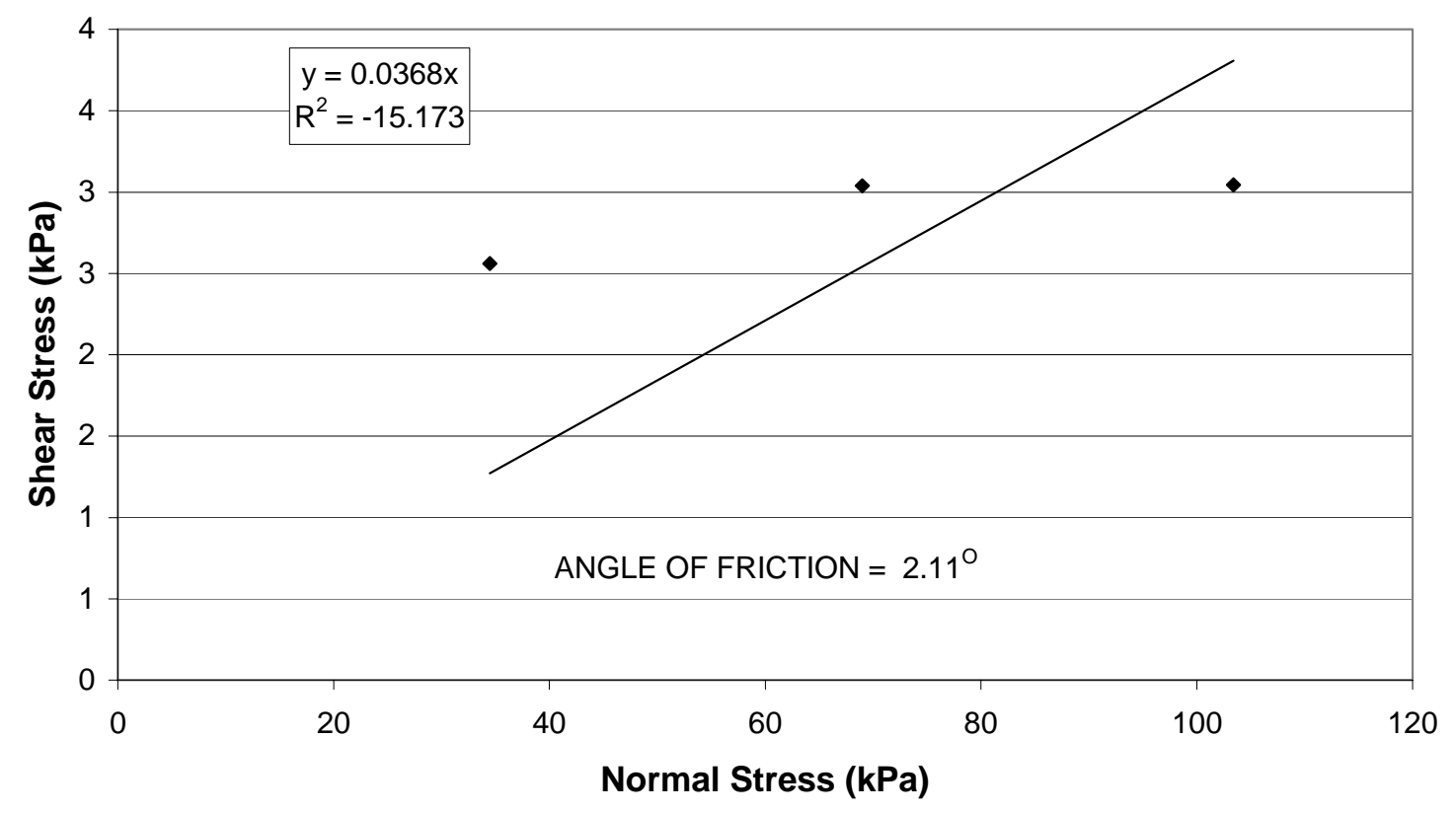

Figure 4.63: Pullout failure envelope for material C-sand interface. 
Figure 4.64, 4.65 and 4.66 shows the pullout shear stress-strain relationships for the interface consisting of material A and silt and water content of $0 \%$. The pullout failure envelope for this interface is shown in Figure 4.67. This figure illustrates an angle of friction equal to 19.21 degrees and an effective cohesion of $4.5 \mathrm{kPa}$.

STRESS-STRAIN PULLOUT RELATIONSHIP

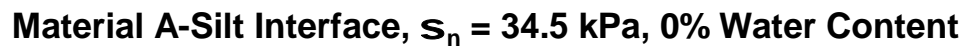

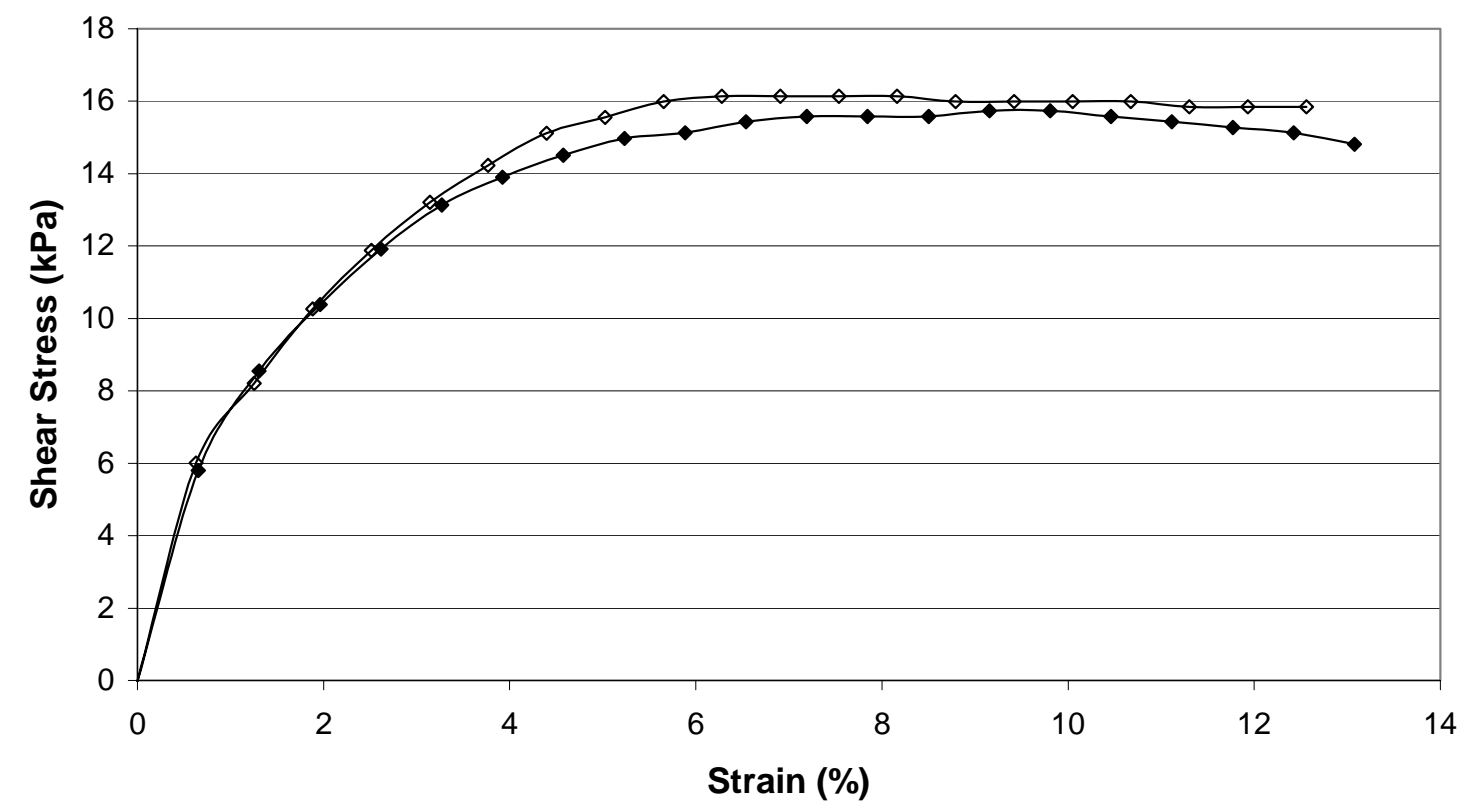

Figure 4.64: Pullout test results for material $\mathrm{A}$ - silt interface at $\mathrm{S}_{\mathrm{n}}=34.5 \mathrm{kPa}$ and $0 \%$ water content. 
STRESS-STRAIN PULLOUT RELATIONSHIP

Material A-Silt Interface, $S_{\mathrm{n}}=69 \mathrm{kPa}, 0 \%$ Water Content

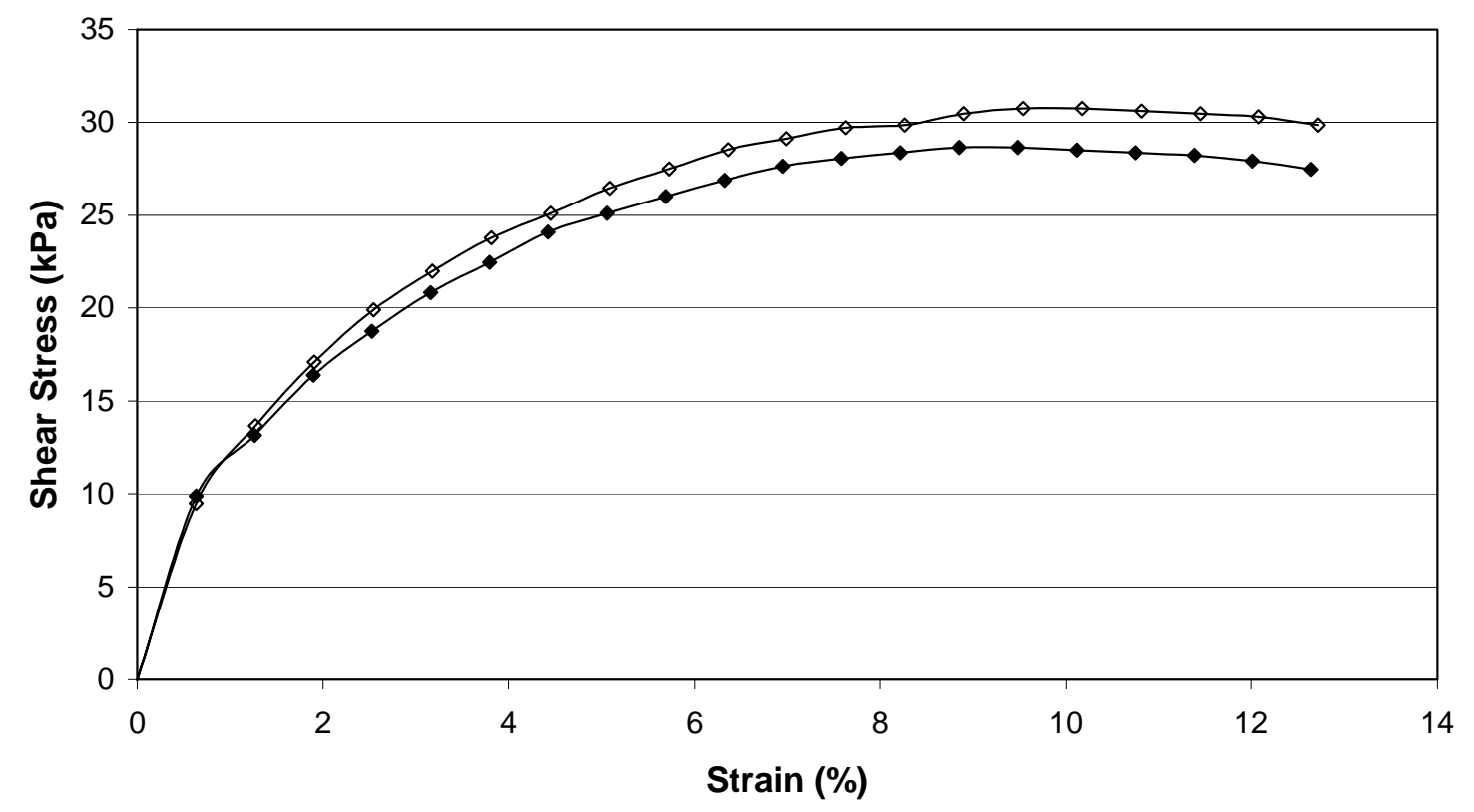

Figure 4.65: Pullout test results for material $A$ - silt interface at $S_{n}=69 \mathrm{kPa}$ and $0 \%$ water content. 
STRESS-STRAIN PULLOUT RELATIONSHIP

Material A-Silt Interface, $S_{n}=103.4 \mathrm{kPa}, 0 \%$ Water Content

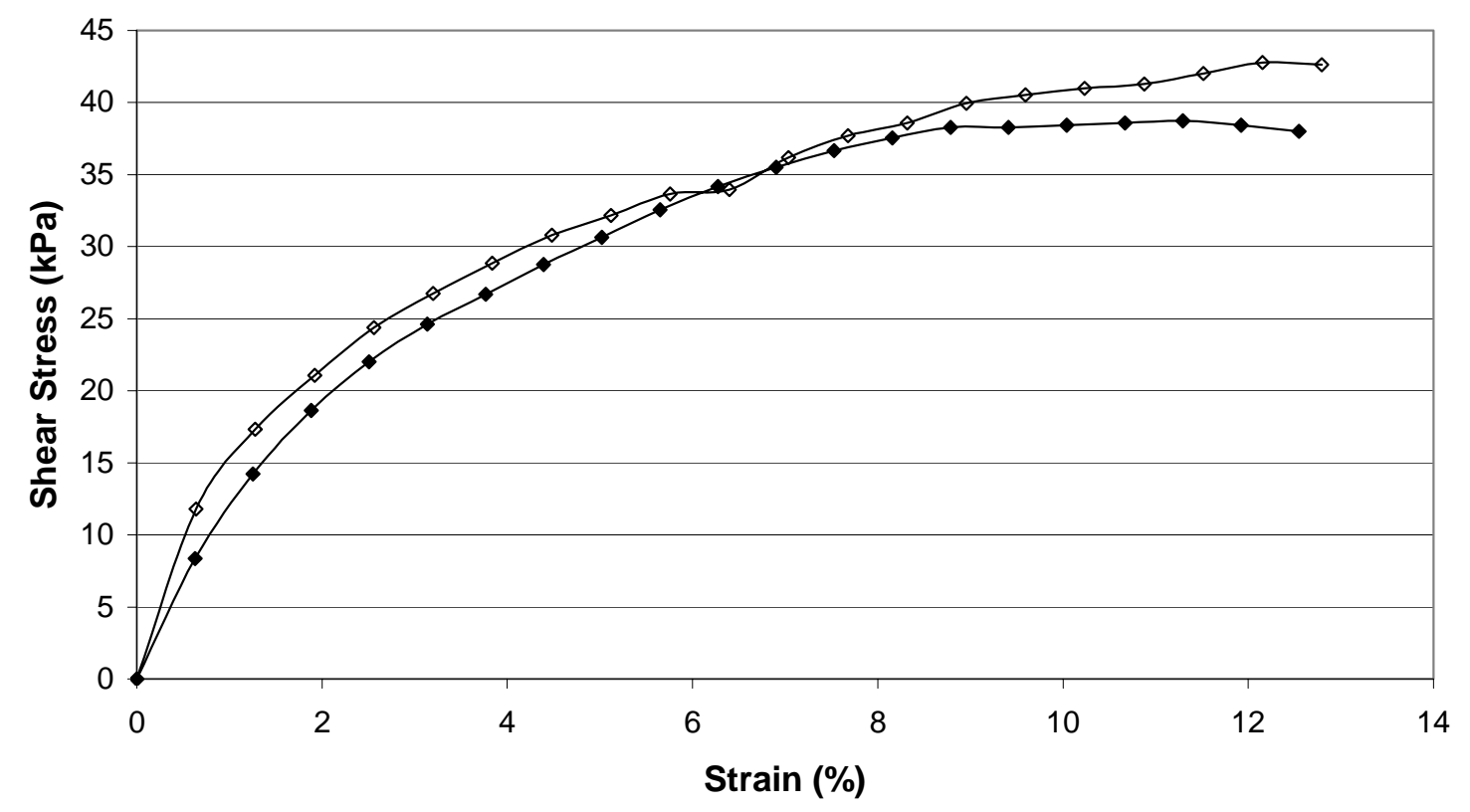

Figure 4.66: Pullout test results for material $\mathrm{A}$ - silt interface at $\mathrm{S}_{\mathrm{n}}=103.4 \mathrm{kPa}$ and $0 \%$ water content. 
PULLOUT FAILURE ENVELOPE Material A-Silt Interface, $0 \%$ Water Content

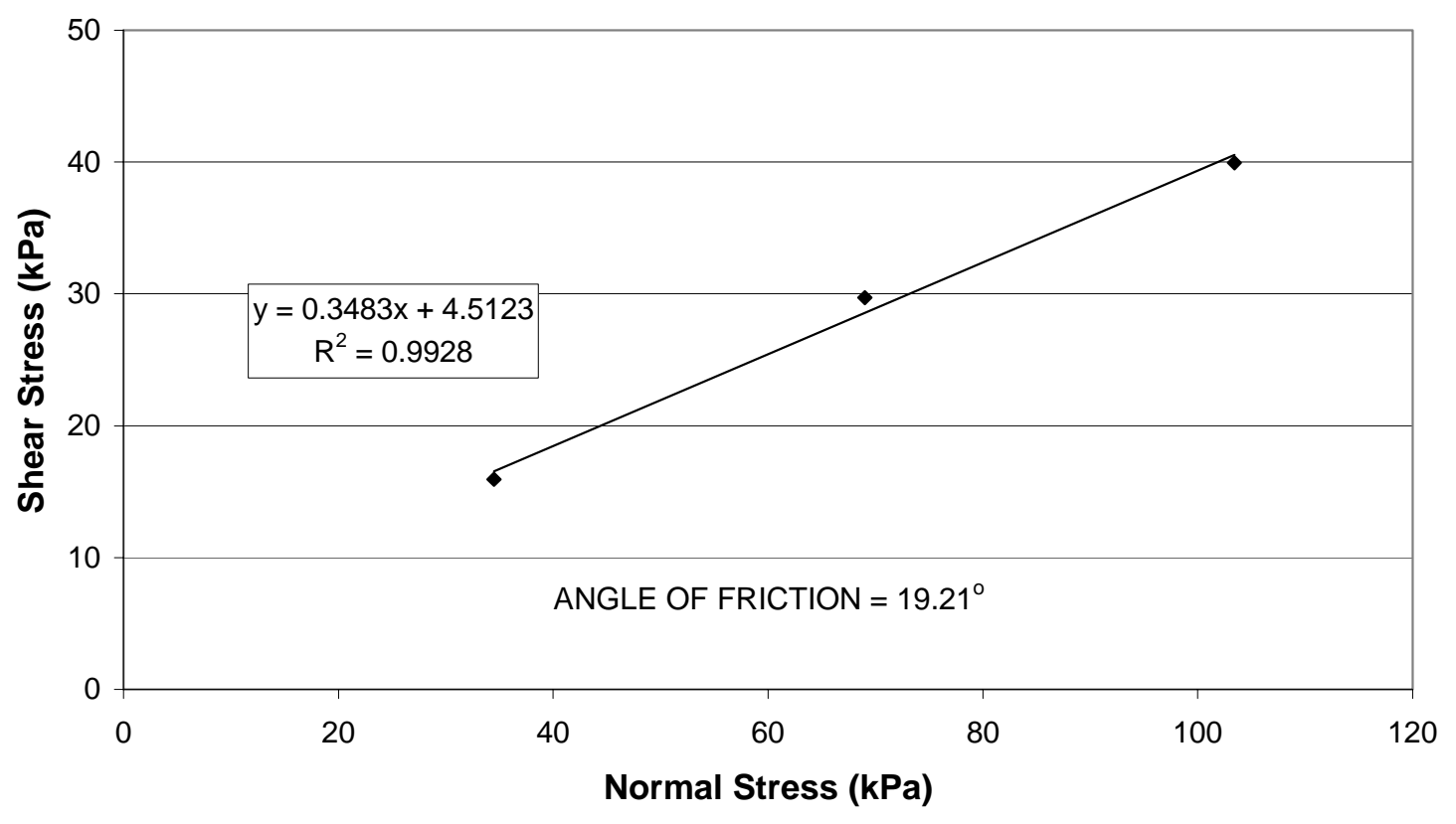

Figure 4.67: Pullout failure envelope for material A - silt interface at $0 \%$ water content. 
Figures 4.68, 4.69 and 4.70 show the pullout stress-strain relationship for material A-silt interface with $10 \%$ water content. Figure 4.71 illustrates the failure envelope for this interface. An angle of friction equal to 15.5 degrees and an effective cohesion equal to $3.9 \mathrm{kPa}$ was recorded.

STRESS-STRAIN PULLOUT RELATIONSHIP Material A-Silt Interface, $S_{n}=\mathbf{3 4 . 5} \mathbf{k P a}, \mathbf{1 0} \%$ Water Content

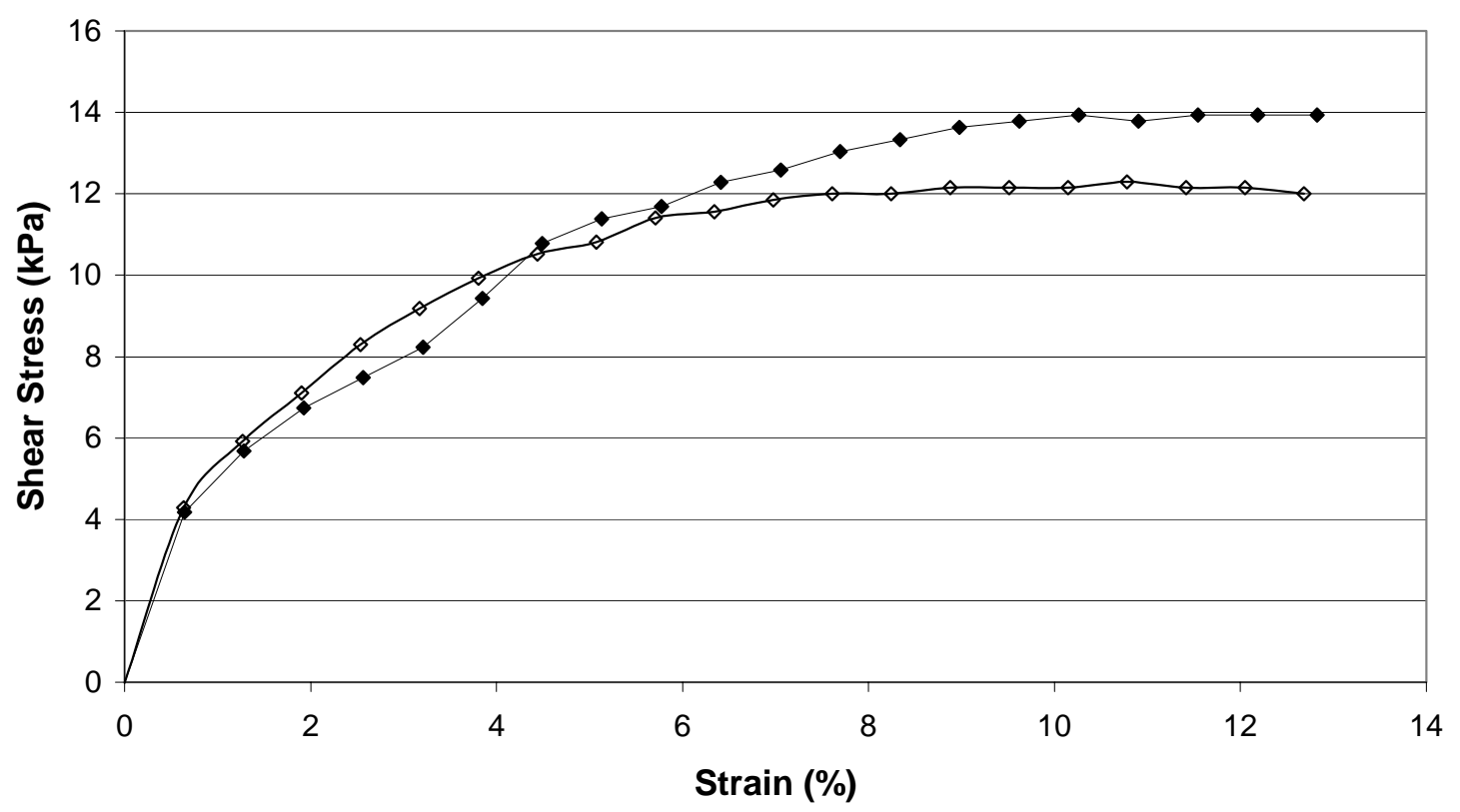

Figure 4.68: Pullout test results for material $\mathrm{A}$ - silt interface at $\mathrm{S}_{\mathrm{n}}=34.5 \mathrm{kPa}$ and $10 \%$ water content. 
STRESS-STRAIN PULLOUT RELATIONSHIP

Material A-Silt Interface, $S_{n}=69 \mathrm{kPa}, 10 \%$ Water Content

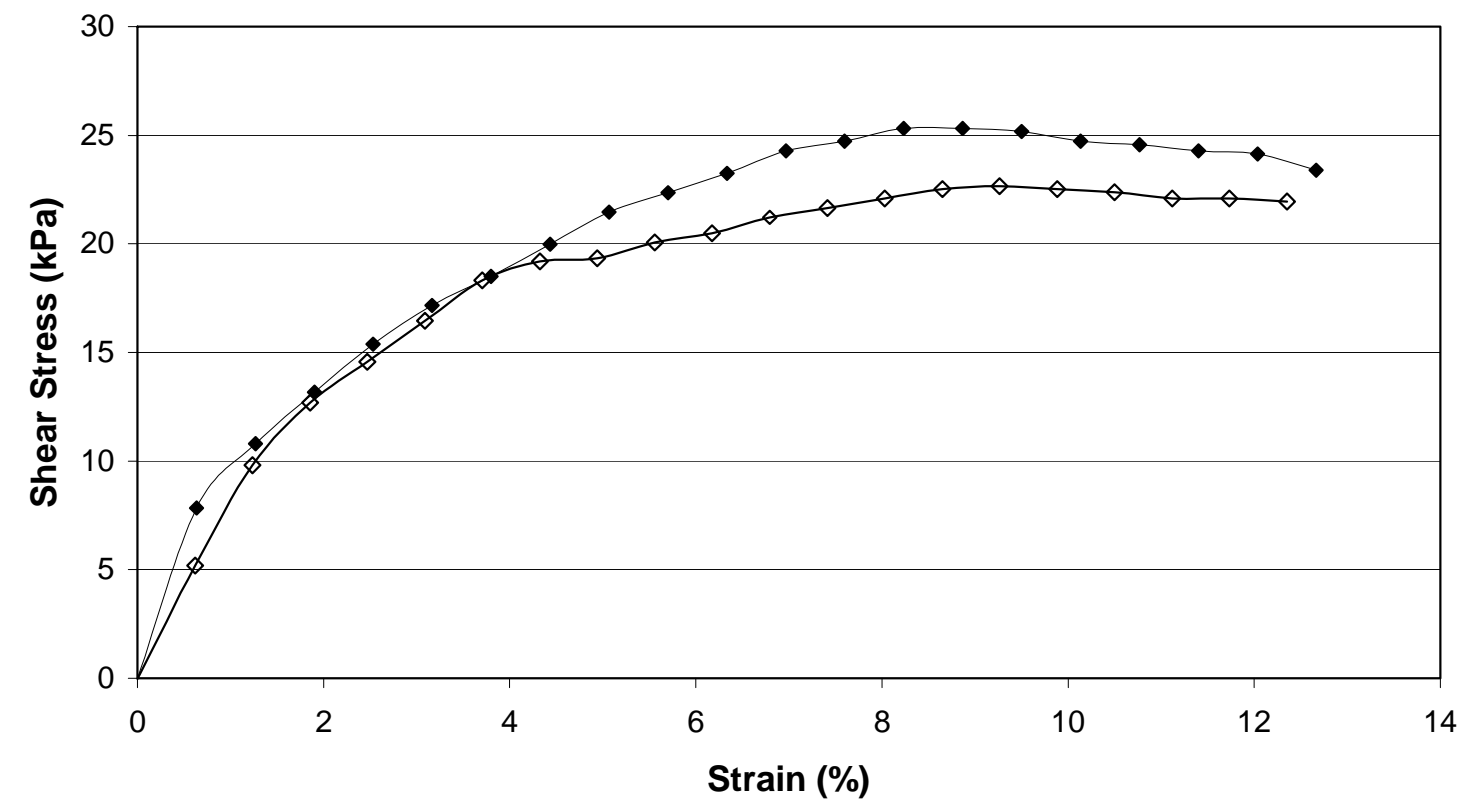

Figure 4.69: Pullout test results for material $A$ - silt interface at $S_{n}=69 \mathrm{kPa}$ and $10 \%$ water content. 
STRESS-STRAIN PULLOUT RELATIONSHIP

Material A-Silt Interface, $S_{n}=103.4 \mathrm{kPa}, 10 \%$ Water Content

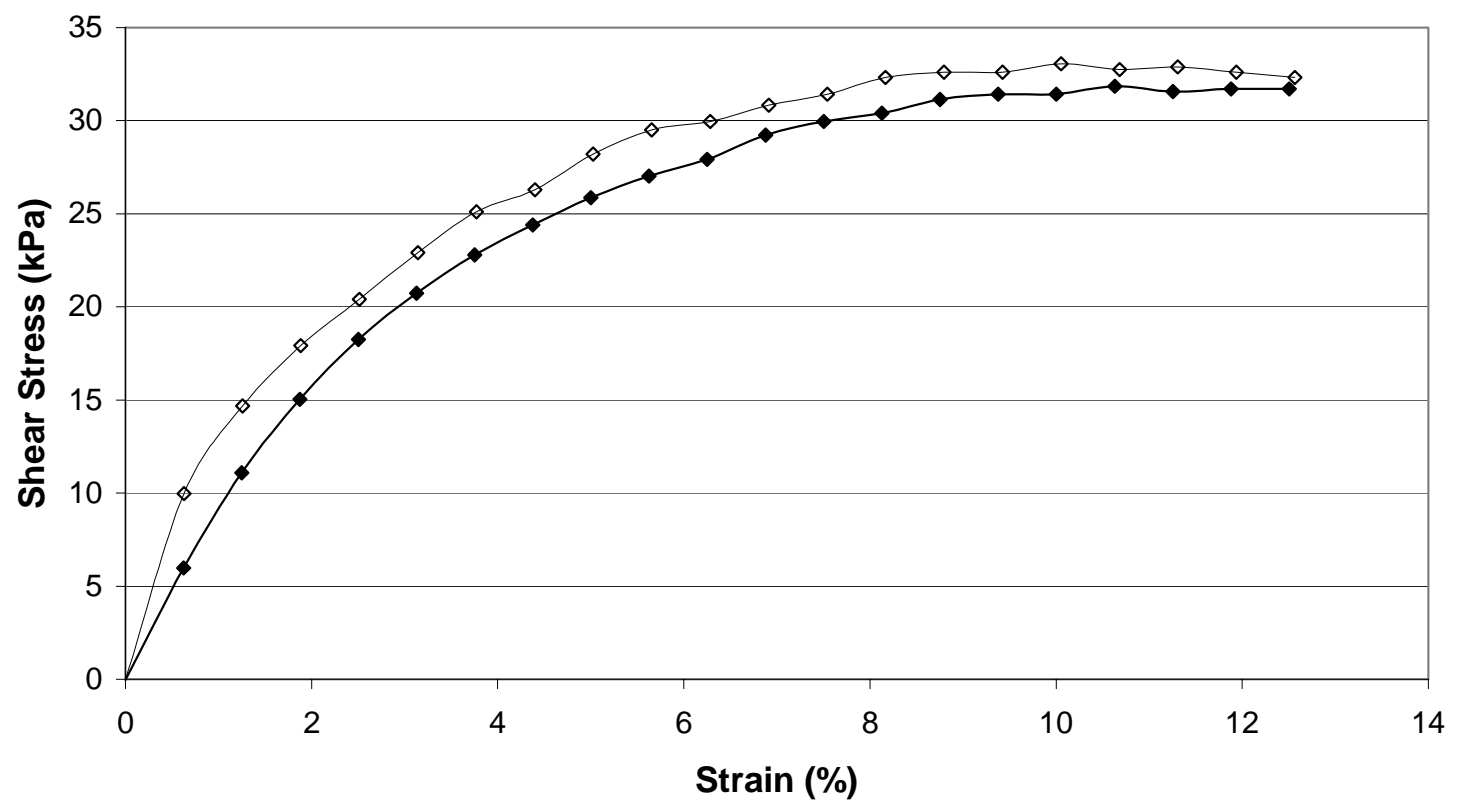

Figure 4.70: Pullout test results for material $A$ - silt interface at $S_{n}=103.4 \mathrm{kPa}$ and $10 \%$ water content. 
PULLOUT FAILURE ENVELOPE Material A-Silt Interface, 10\% Water Content

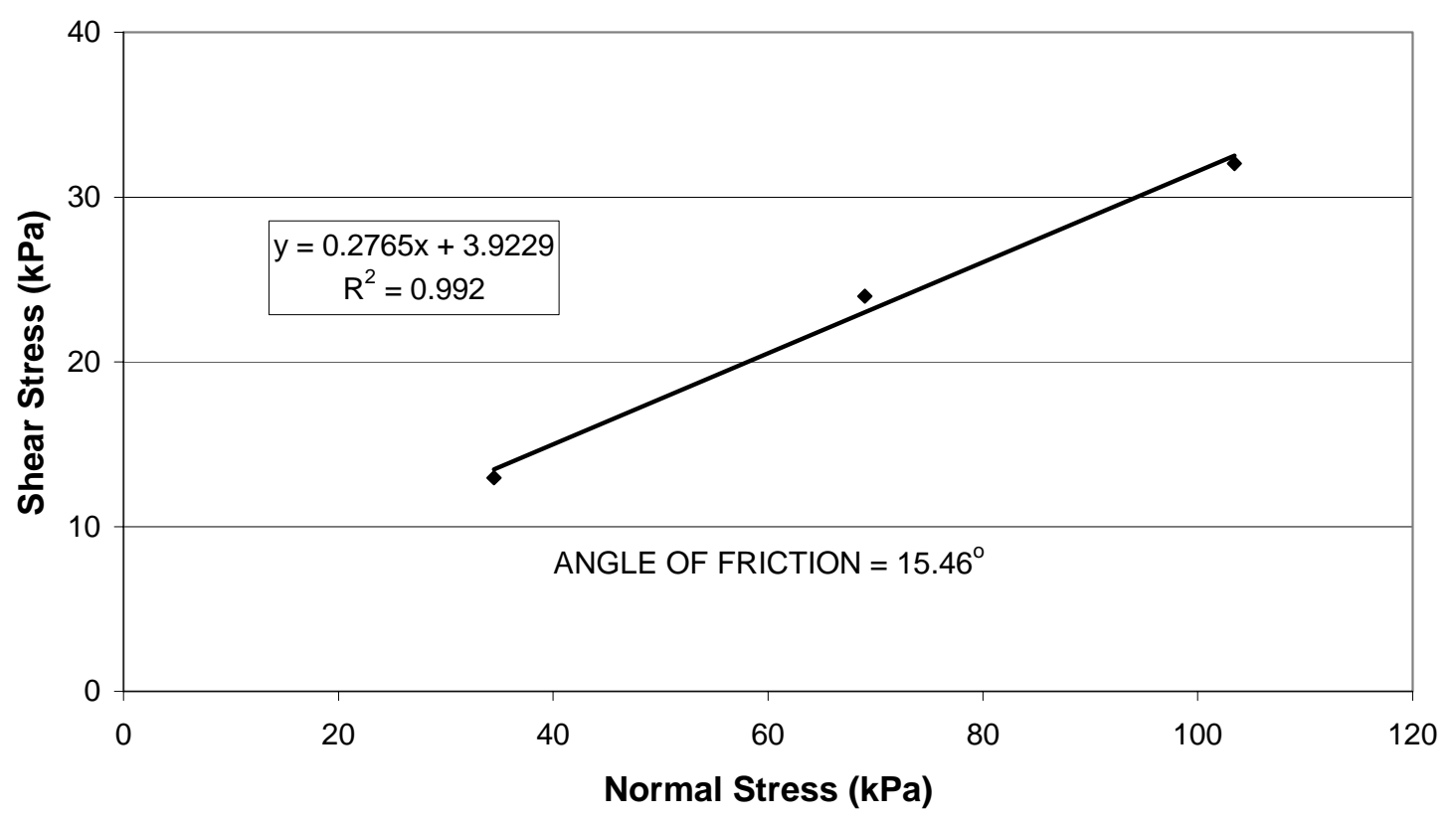

Figure 4.71: Pullout failure envelope for material A - silt interface at $10 \%$ water content. 
In the following three figures, Figure 4.72, 4.73 and 4.74, the pullout stress-strain relationship for material A-silt interface with $15 \%$ water content is presented. An angle of friction equal to 16.78 degrees is shown in Figure 4.75. This figure illustrates the failure envelope for the interface and shows an effective cohesion of $1.1 \mathrm{kPa}$.

STRESS-STRAIN PULLOUT RELATIONSHIP Material A-Silt Interface, $S_{n}=\mathbf{3 4 . 5}$ kPa, 15\% Water Content

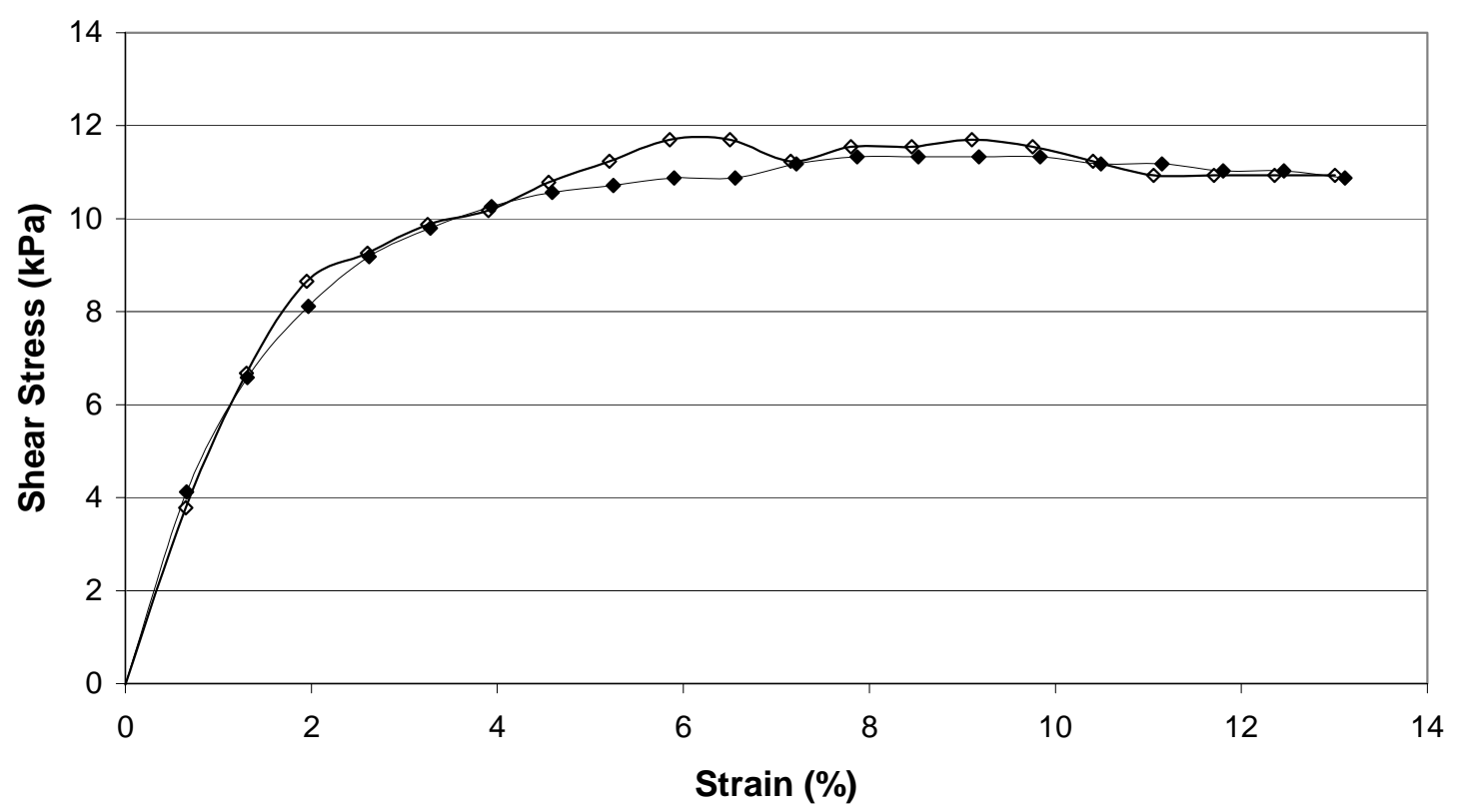

Figure 4.72: Pullout test results for material $\mathrm{A}$ - silt interface at $\mathrm{S}_{\mathrm{n}}=34.5 \mathrm{kPa}$ and $15 \%$ water content. 
STRESS-STRAIN PULLOUT RELATIONSHIP

Material A-Silt Interface, $S_{n}=69 \mathrm{kPa}, 15 \%$ Water Content

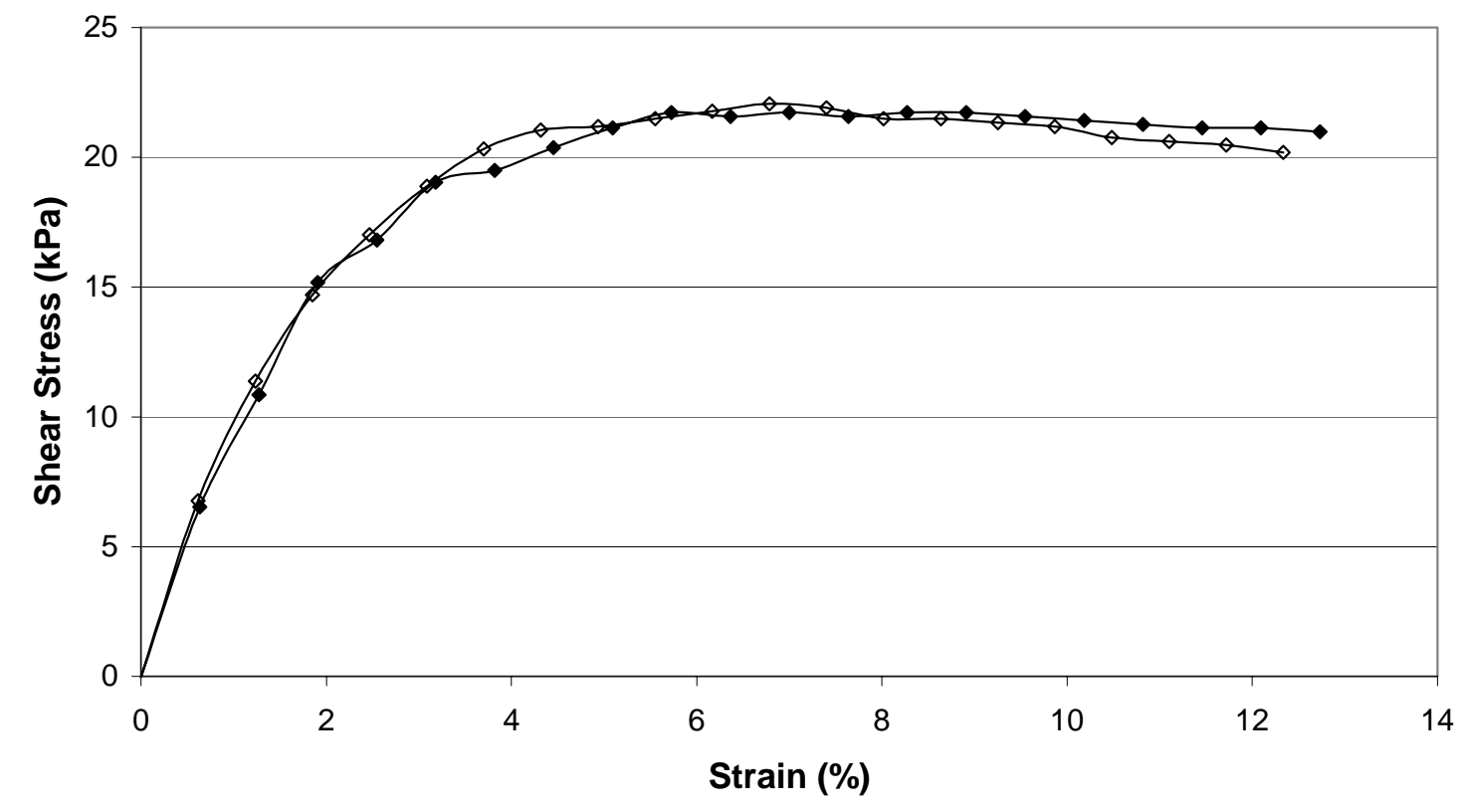

Figure 4.73: Pullout test results for material $A$ - silt interface at $S_{n}=69 \mathrm{kPa}$ and $15 \%$ water content. 
STRESS-STRAIN PULLOUT RELATIONSHIP

Material A-Silt Interface, $S_{n}=103.4 \mathrm{kPa}, 15 \%$ Water Content

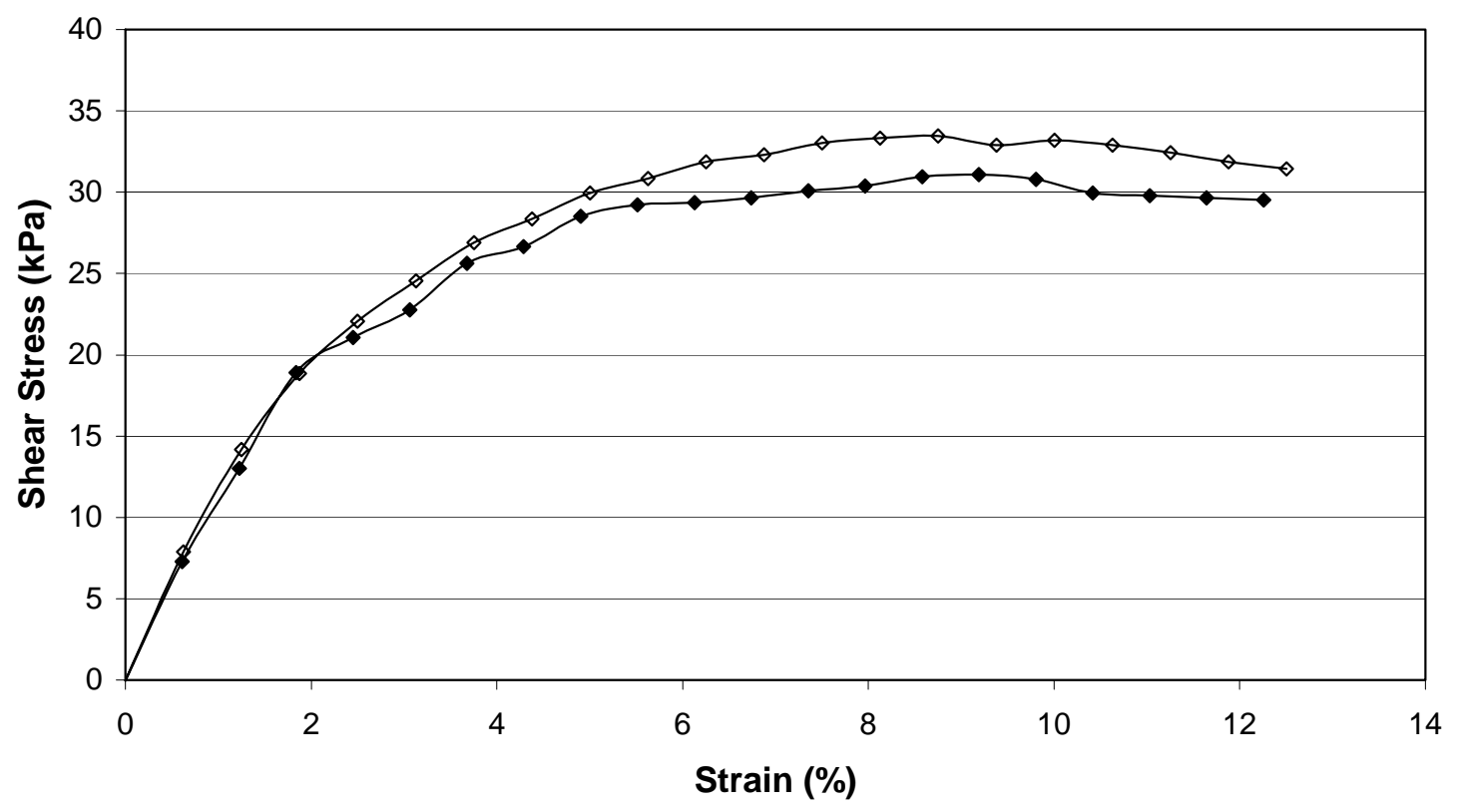

Figure 4.74: Pullout test results for material $A$ - silt interface at $S_{n}=103.4 \mathrm{kPa}$ and $15 \%$ water content. 
PULLOUT FAILURE ENVELOPE Material A-Silt Interface, 15\% Water Content

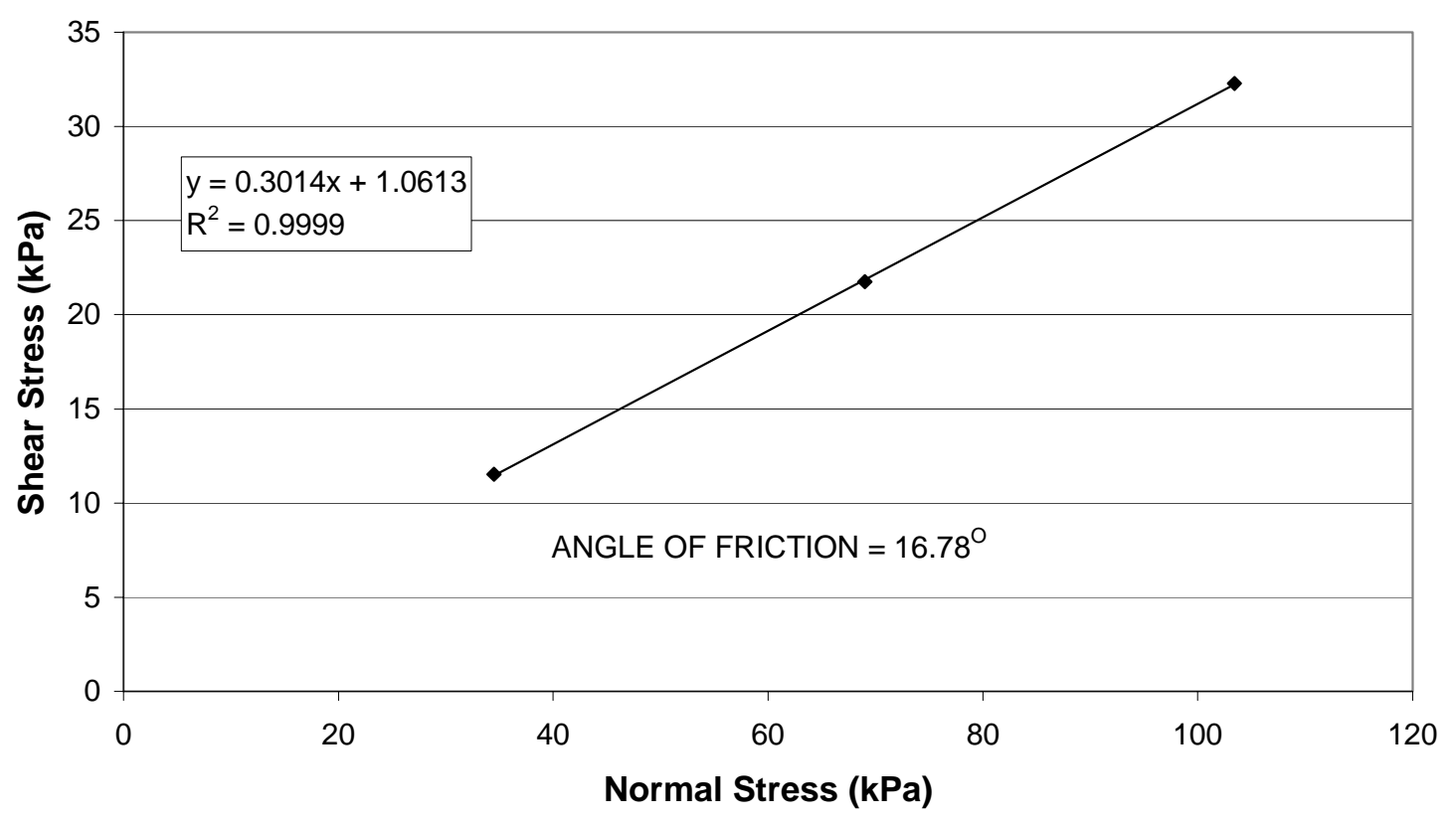

Figure 4.75: Pullout failure envelope for material A - silt interface at $15 \%$ water content. 
Figure 4.76, 4.78 and 4.79 shows the pullout shear stress-strain relationships for the interface consisting of material B and silt with $0 \%$ water content. The pullout failure envelope for this interface is shown in Figure 4.80. This figure illustrates an angle of friction equal to 4.22 degrees and an effective cohesion of $9.3 \mathrm{kPa}$.

STRESS-STRAIN PULLOUT RELATIONSHIP Material B-Silt Interface, $S_{n}=34.5 \mathrm{kPa}, 0 \%$ Water Content

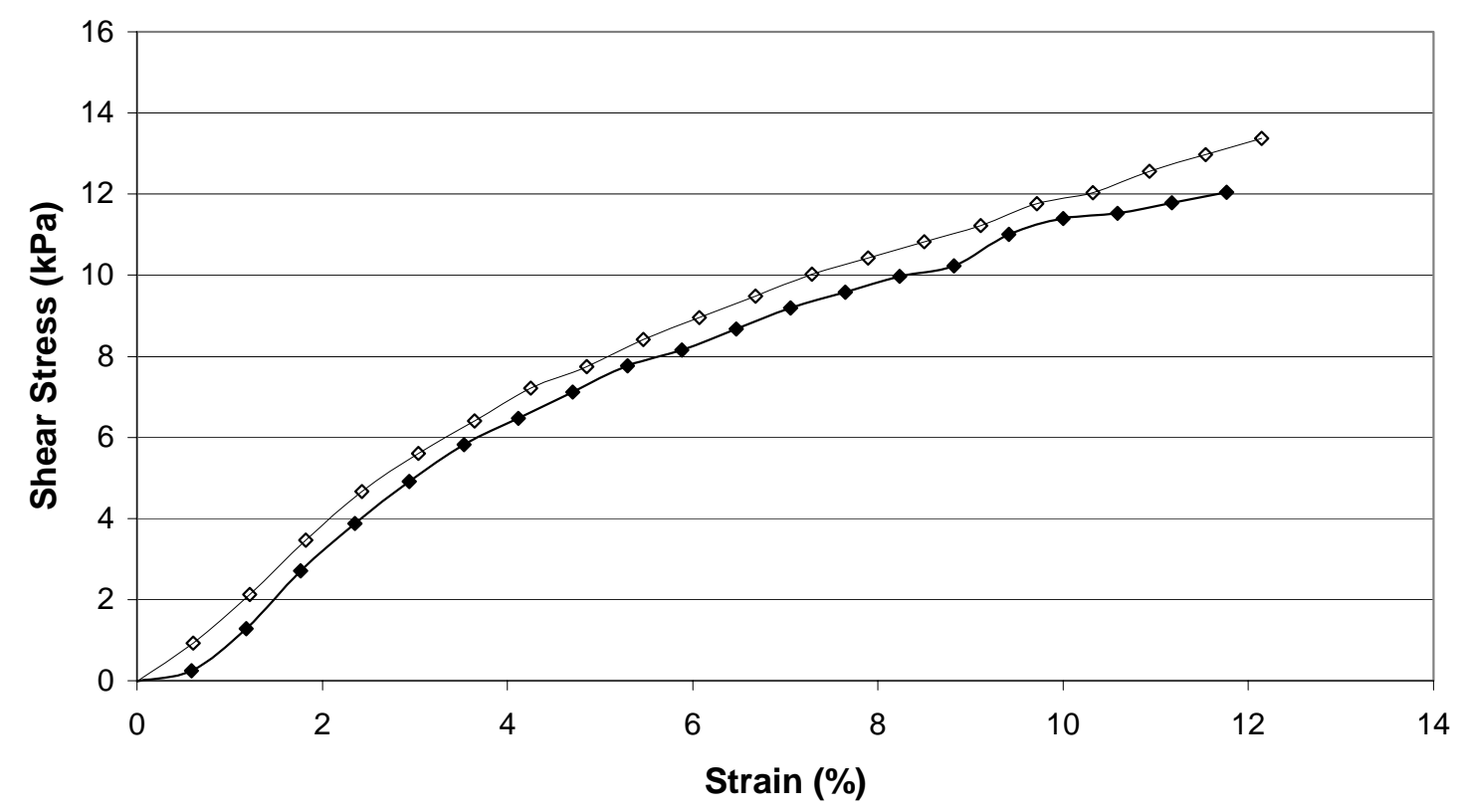

Figure 4.76: Pullout test results for material $B$ - silt interface at $S_{n}=34.5 \mathrm{kPa}$ and $0 \%$ water content. 


\section{STRESS-STRAIN PULLOUT RELATIONSHIP}

Material B-Silt Interface, $S_{n}=69 \mathrm{kPa}, 0 \%$ Water Content

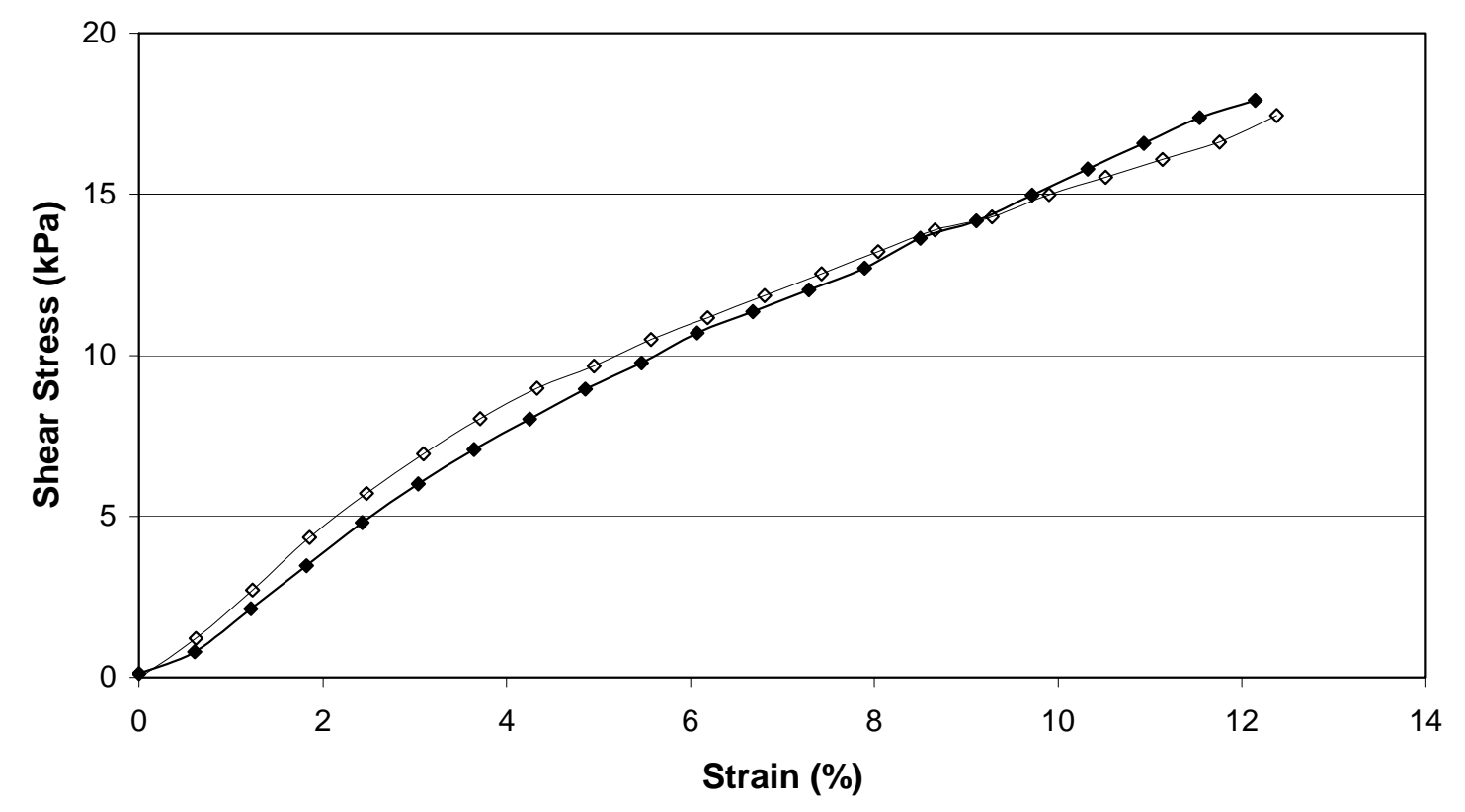

Figure 4.77: Pullout test results for material $B$ - silt interface at $S_{n}=69 \mathrm{kPa}$ and $0 \%$ water content. 
STRESS-STRAIN PULLOUT RELATIONSHIP

Material B-Silt Interface, $S_{n}=103.4 \mathrm{kPa}, 0 \%$ Water Content

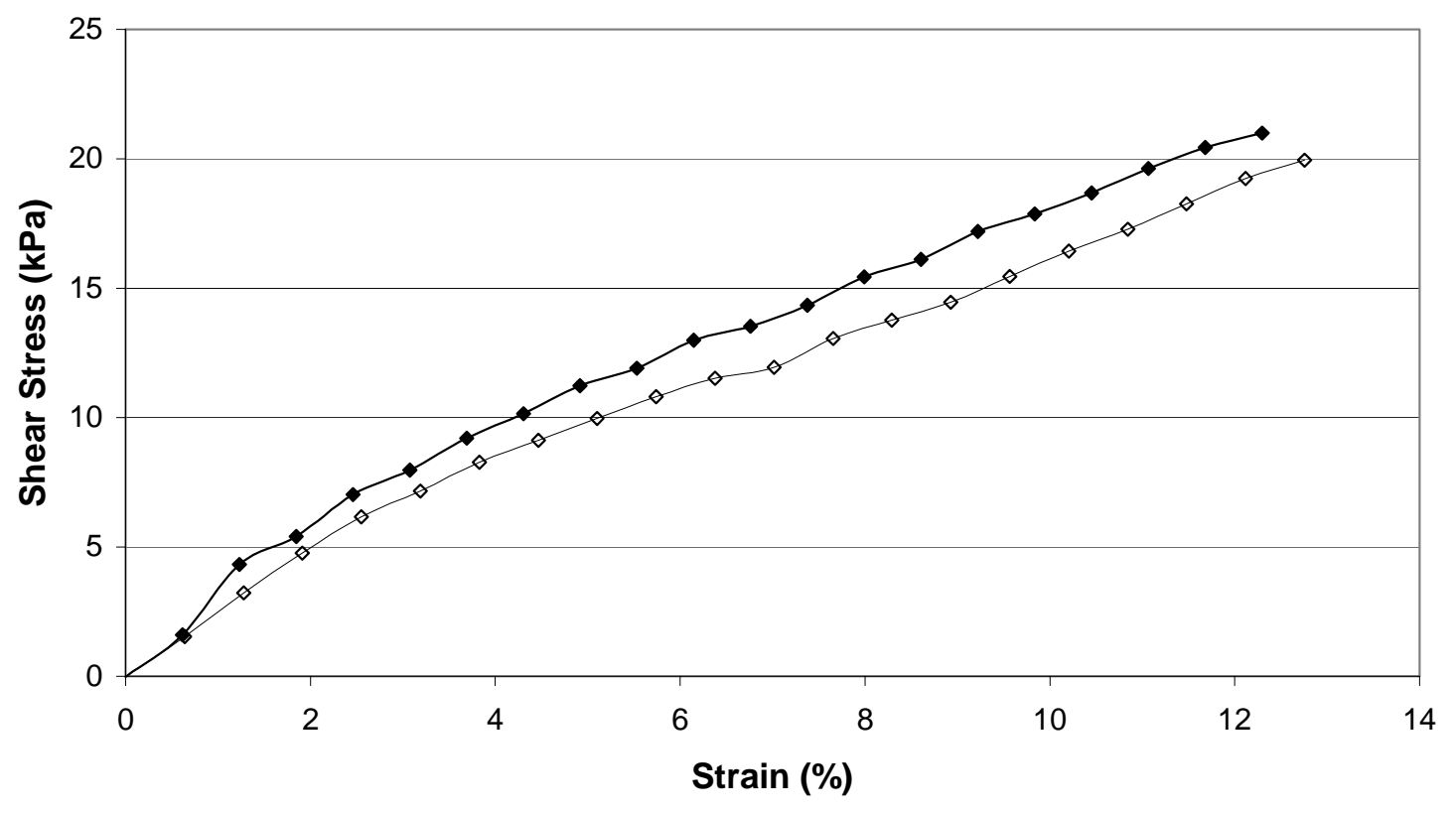

Figure 4.78: Pullout test results for material $B$ - silt interface at $S_{n}=103.4 \mathrm{kPa}$ and $0 \%$ water content. 


\section{PULLOUT FAILURE ENVELOPE \\ Material B-Silt Interface, 0\% Water Content}

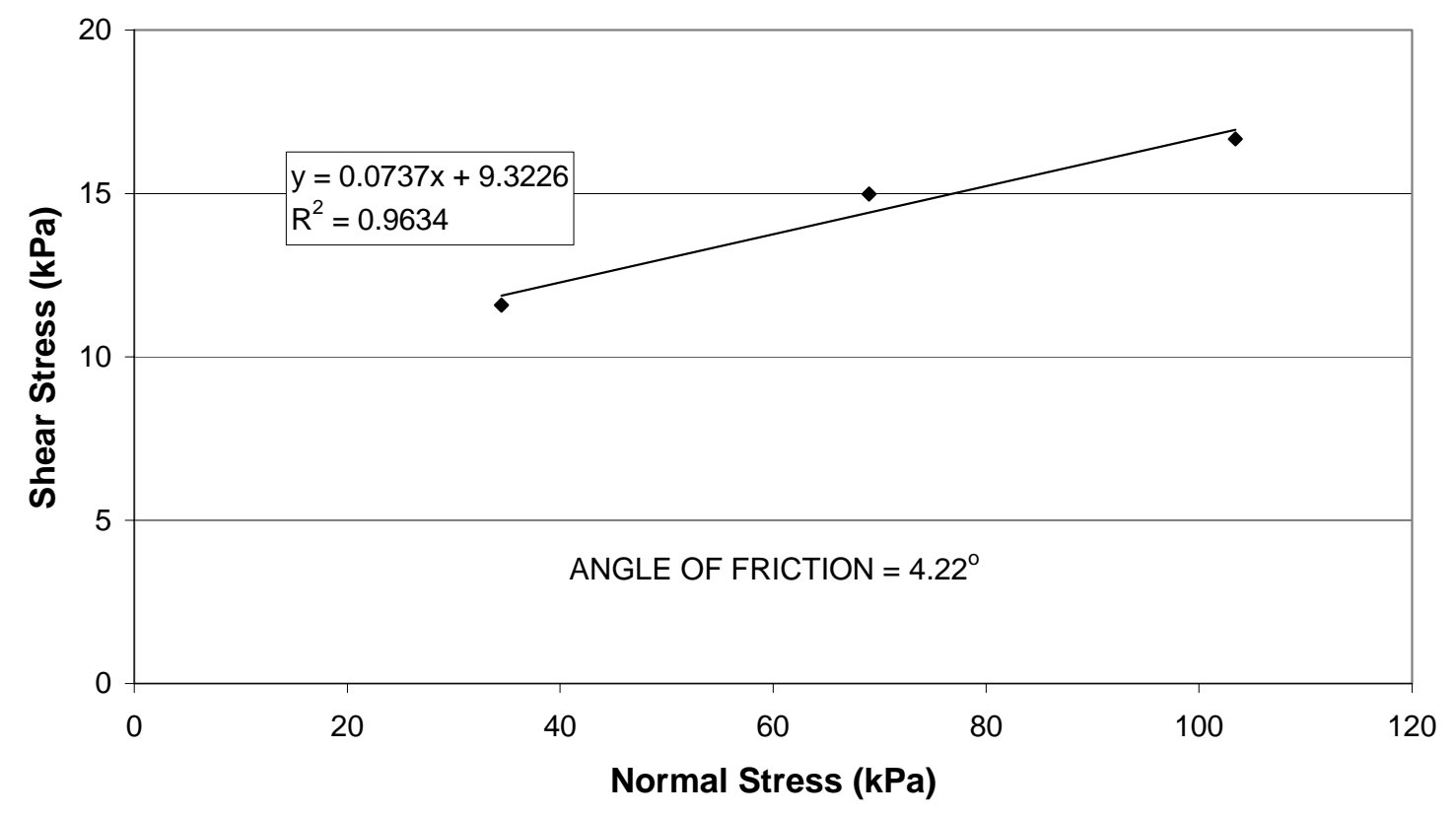

Figure 4.79: Pullout failure envelope for material B - silt interface at $0 \%$ water content. 
Figures 4.80, 4.81 and 4.82 show the pullout stress-strain relationship for material B-silt interface with $10 \%$ water content. Figure 4.83 illustrates the failure envelope for this interface. An angle of friction equal to 5.0 degrees and an effective cohesion equal to $7.4 \mathrm{kPa}$ was recorded.

STRESS-STRAIN PULLOUT RELATIONSHIP Material B-Silt Interface, $S_{n}=34.5 \mathrm{kPa}, \mathbf{1 0} \%$ Water Content

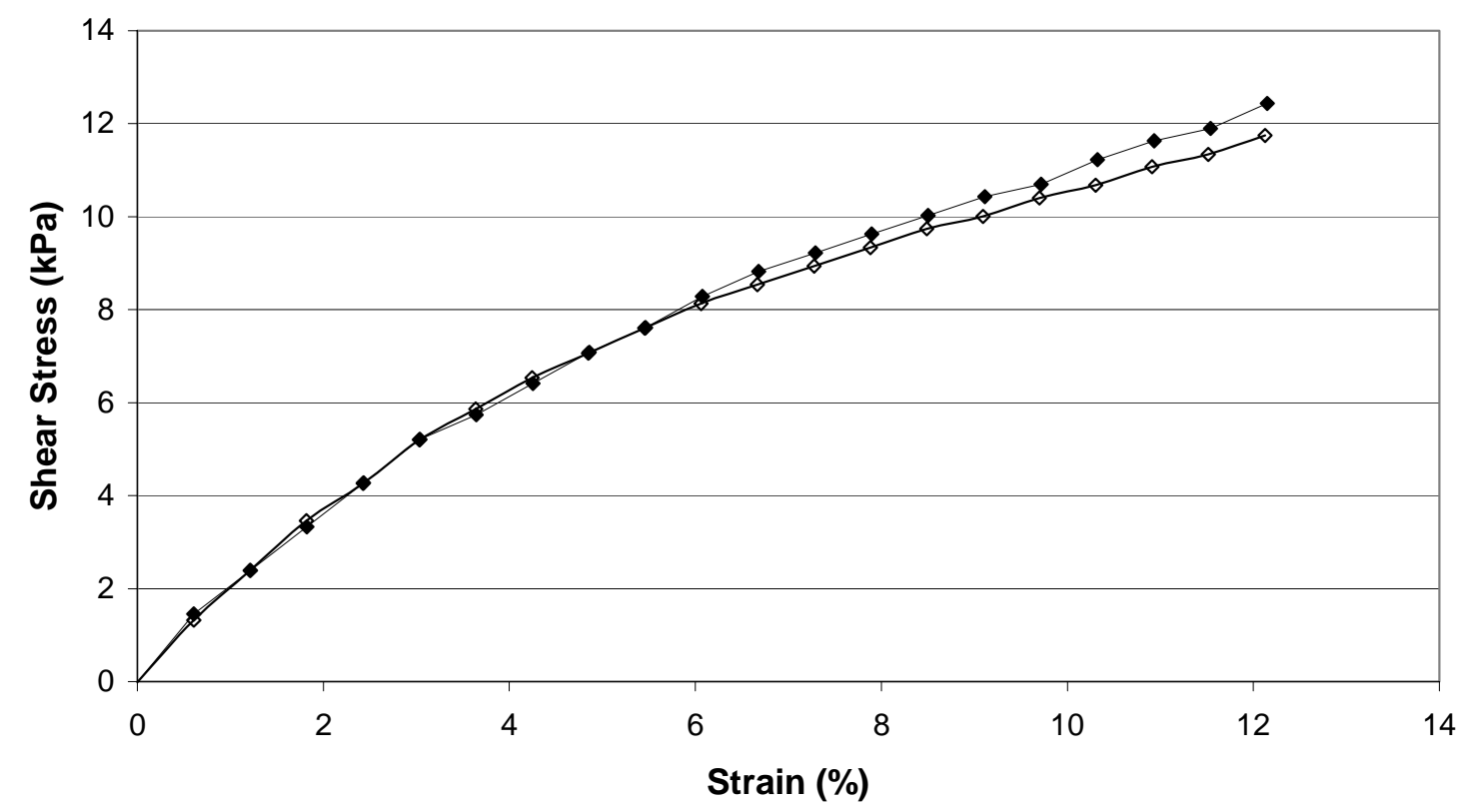

Figure 4.80: Pullout test results for material $B$ - silt interface at $S_{n}=34.5 \mathrm{kPa}$ and $10 \%$ water content. 
STRESS-STRAIN PULLOUT RELATIONSHIP

Material B-Silt Interface, $S_{n}=69 \mathrm{kPa}, 10 \%$ Water Content

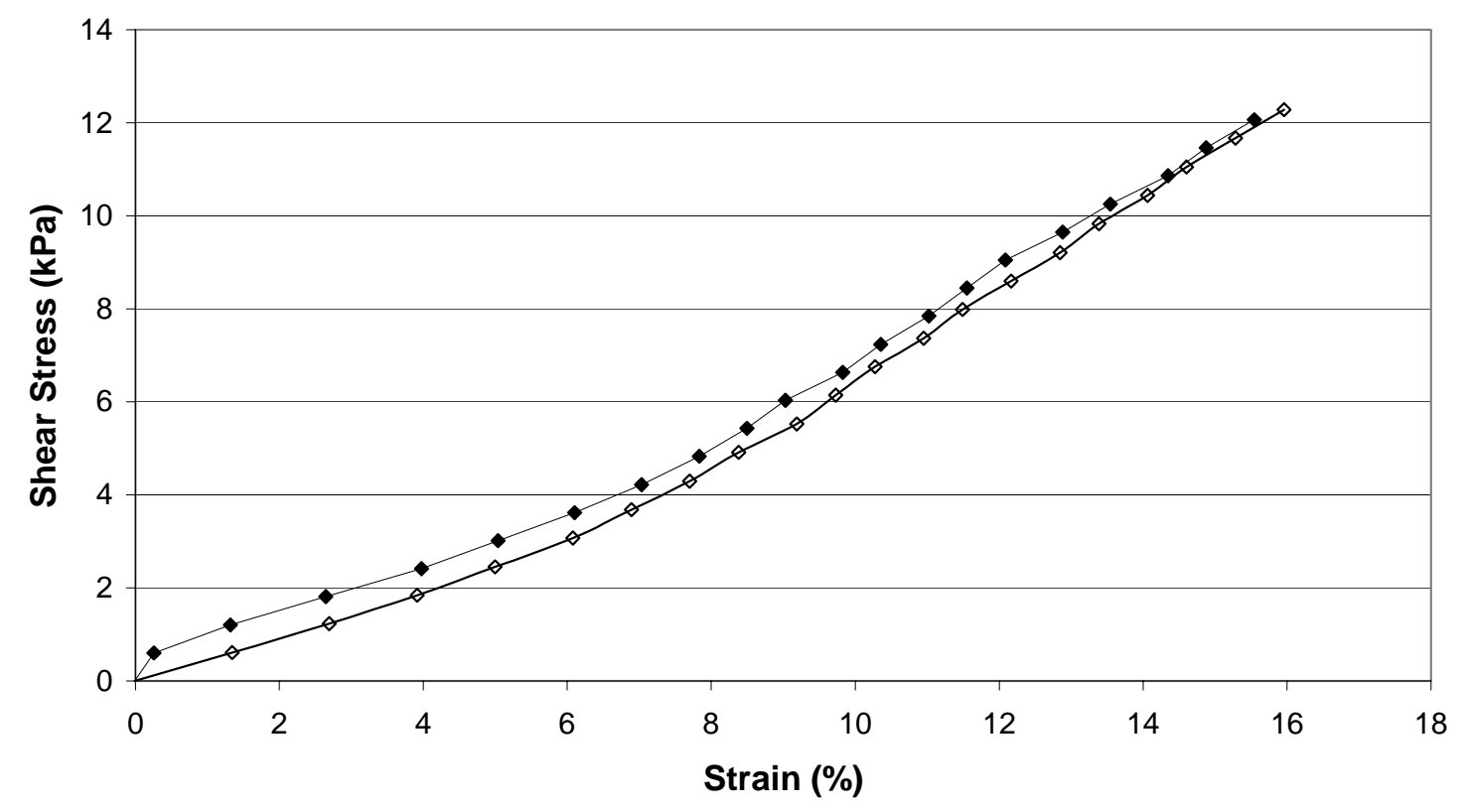

Figure 4.81: Pullout test results for material B - silt interface at $S_{n}=69 \mathrm{kPa}$ and $10 \%$ water content. 
STRESS-STRAIN PULLOUT RELATIONSHIP

Material B-Silt Interface, $S_{n}=103.4 \mathrm{kPa}, 10 \%$ Water Content

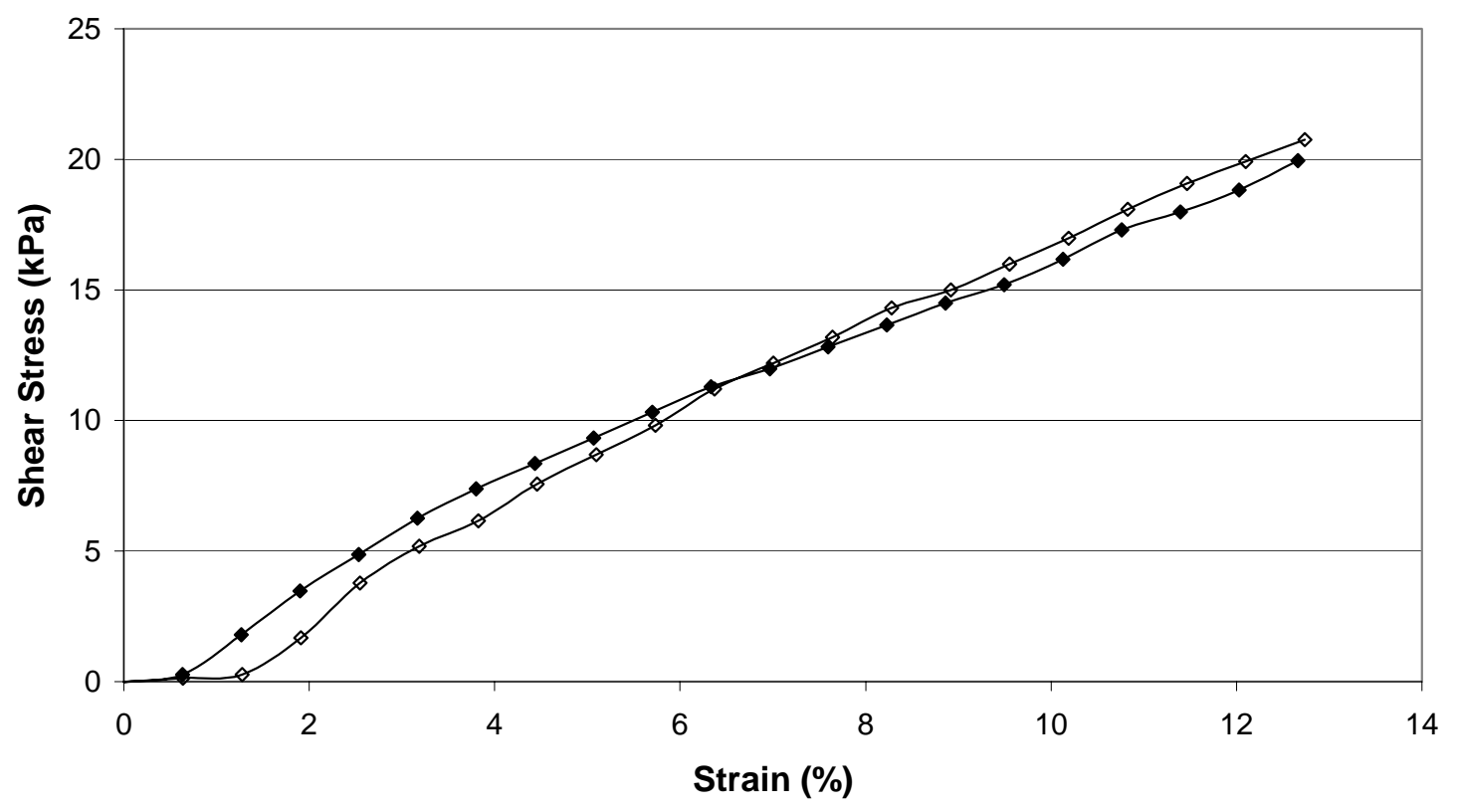

Figure 4.82: Pullout test results for material $B$ - silt interface at $S_{n}=103.4 \mathrm{kPa}$ and $10 \%$ water content. 
PULLOUT FAILURE ENVELOPE Material B-Silt Interface, 10\% Water Content

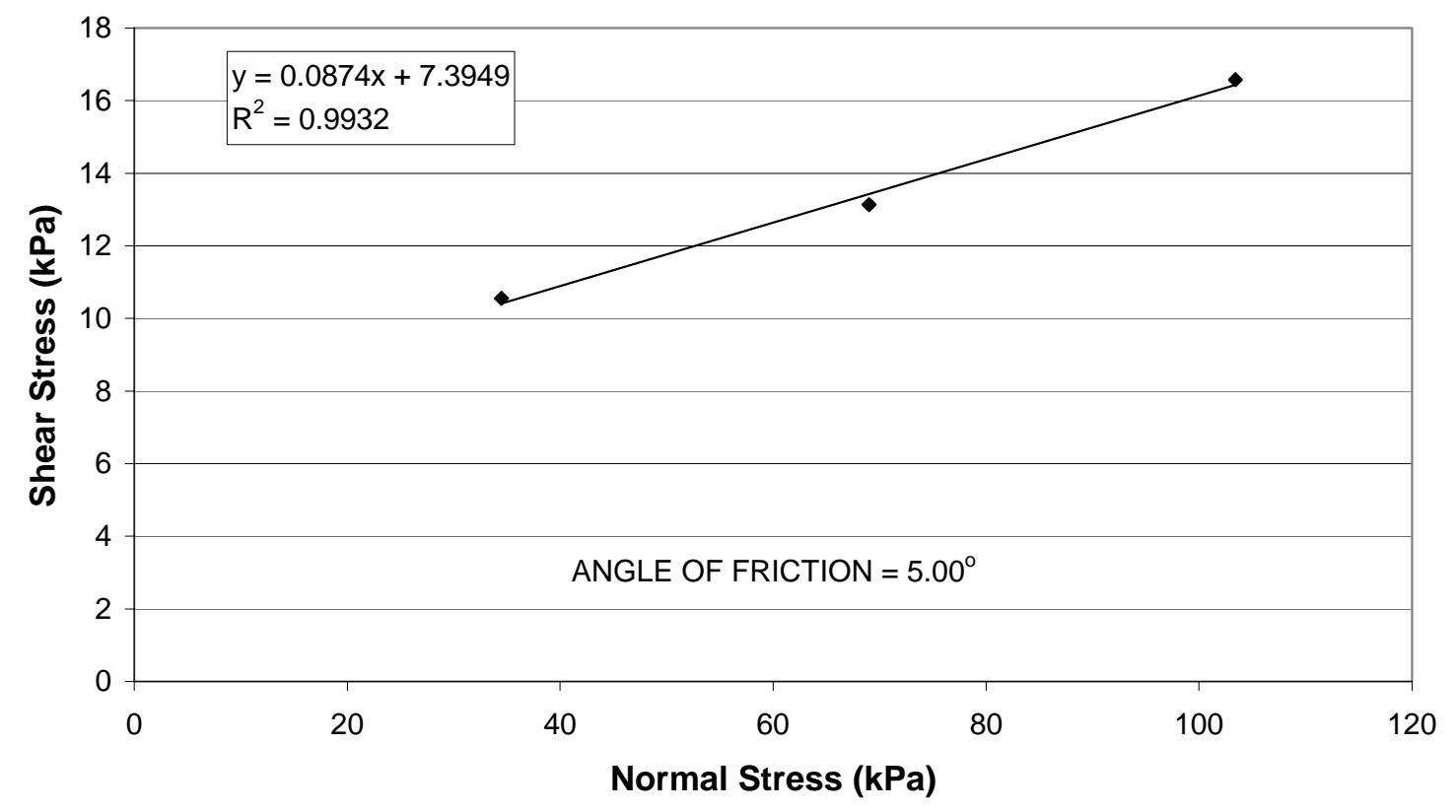

Figure 4.83: Pullout failure envelope for material B - silt interface at $10 \%$ water content. 
In the following three figures, Figure 4.84, 4.85 and 4.86, the pullout stress-strain relationship for material B-sand is presented. An angle of friction equal to 4.06 degrees is shown in Figure 4.87. This figure illustrates the failure envelope for the interface and shows an effective cohesion of $7.5 \mathrm{kPa}$.

STRESS-STRAIN PULLOUT RELATIONSHIP Material B-Silt Interface, $S_{n}=34.5 \mathrm{kPa}, \mathbf{1 5} \%$ Water Content

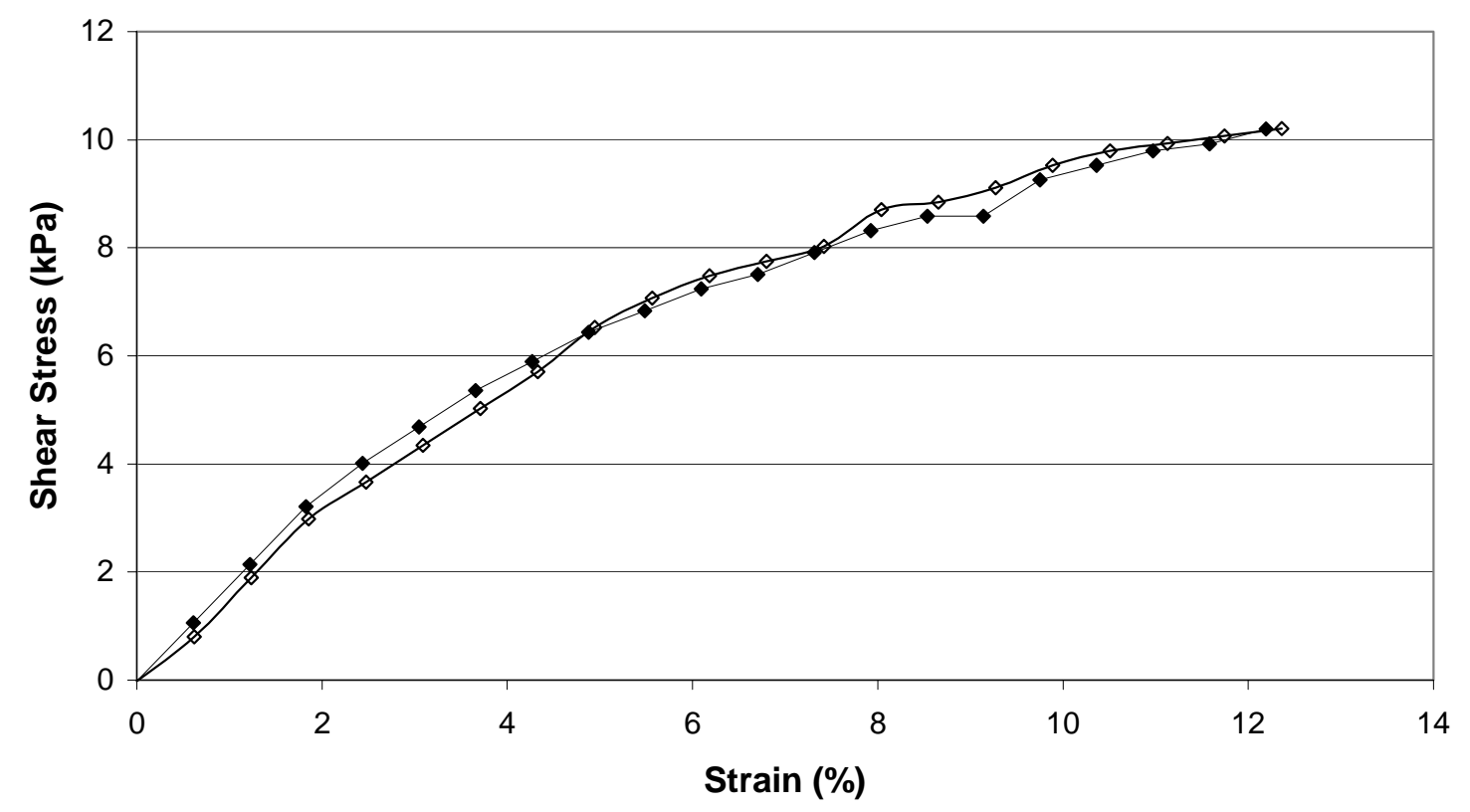

Figure 4.84: Pullout test results for material $B$ - silt interface at $S_{n}=34.5 \mathrm{kPa}$ and $15 \%$ water content. 
STRESS-STRAIN PULLOUT RELATIONSHIP

\begin{abstract}
Material B-Silt Interface, $S_{n}=69 \mathrm{kPa}, 15 \%$ Water Content
\end{abstract}

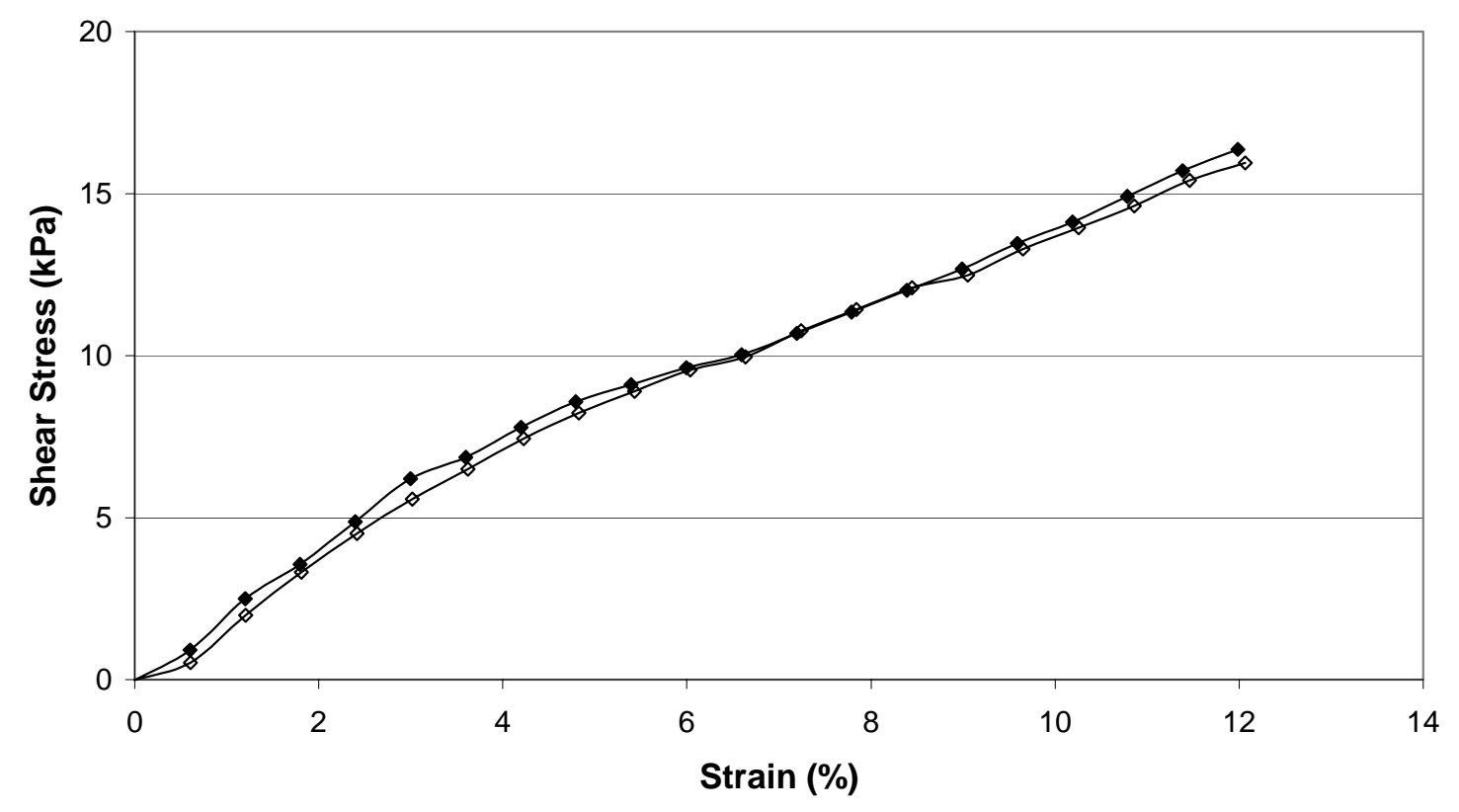

Figure 4.85: Pullout test results for material B - silt interface at $S_{n}=69 \mathrm{kPa}$ and $15 \%$ water content. 
STRESS-STRAIN PULLOUT RELATIONSHIP

Material B-Silt Interface, $S_{n}=103.4 \mathrm{kPa}, 15 \%$ Water Content

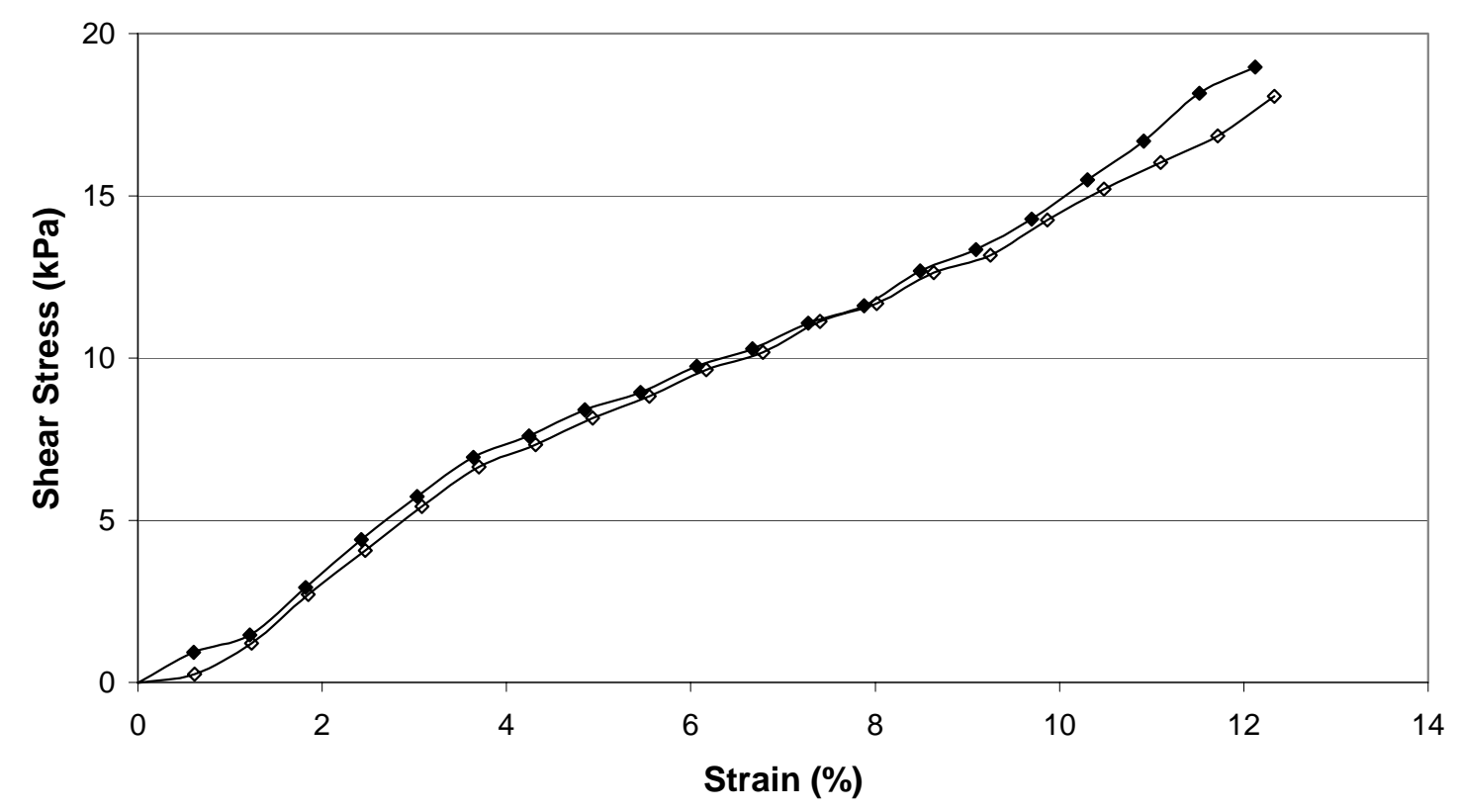

Figure 4.86: Pullout test results for material $B$ - silt interface at $S_{n}=103.4 \mathrm{kPa}$ and $15 \%$ water content. 
PULLOUT FAILURE ENVELOPE Material B-Silt Interface, 15\% Water Content

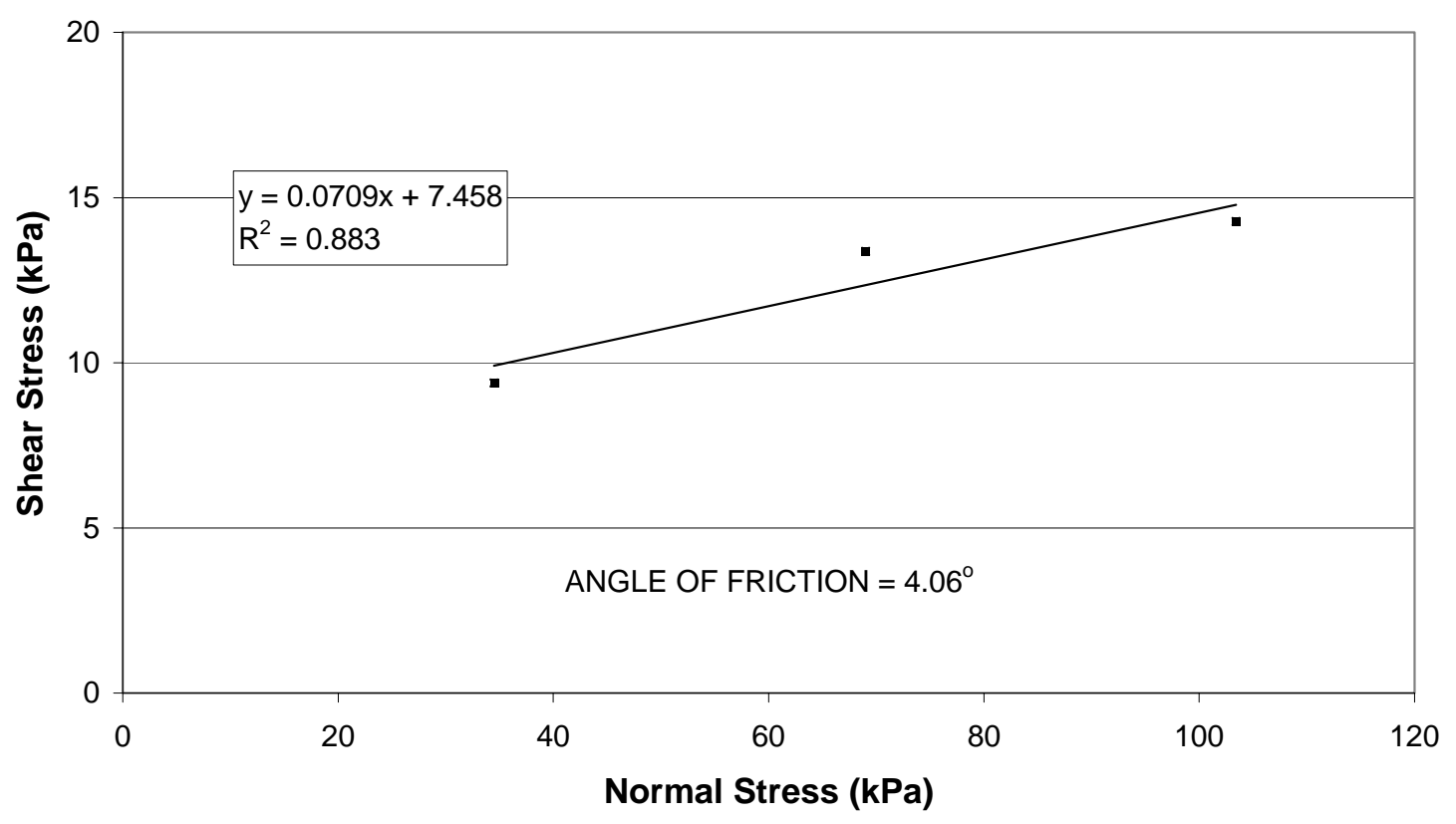

Figure 4.87: Pullout failure envelope for material B - silt interface at $15 \%$ water content. 
Figure 4.88, 4.89 and 4.90 shows the pullout shear stress-strain relationships for the interface consisting of material $\mathrm{C}$ and sand. The pullout failure envelope for this interface is shown in Figure 4.91. This figure illustrates an angle of friction equal to 0.33 degrees and an effective cohesion of $2.2 \mathrm{kPa}$.

STRESS-STRAIN PULLOUT RELATIONSHIP Material C-Silt Interface, $S_{n}=34.5 \mathrm{kPa}, 0 \%$ Water Content

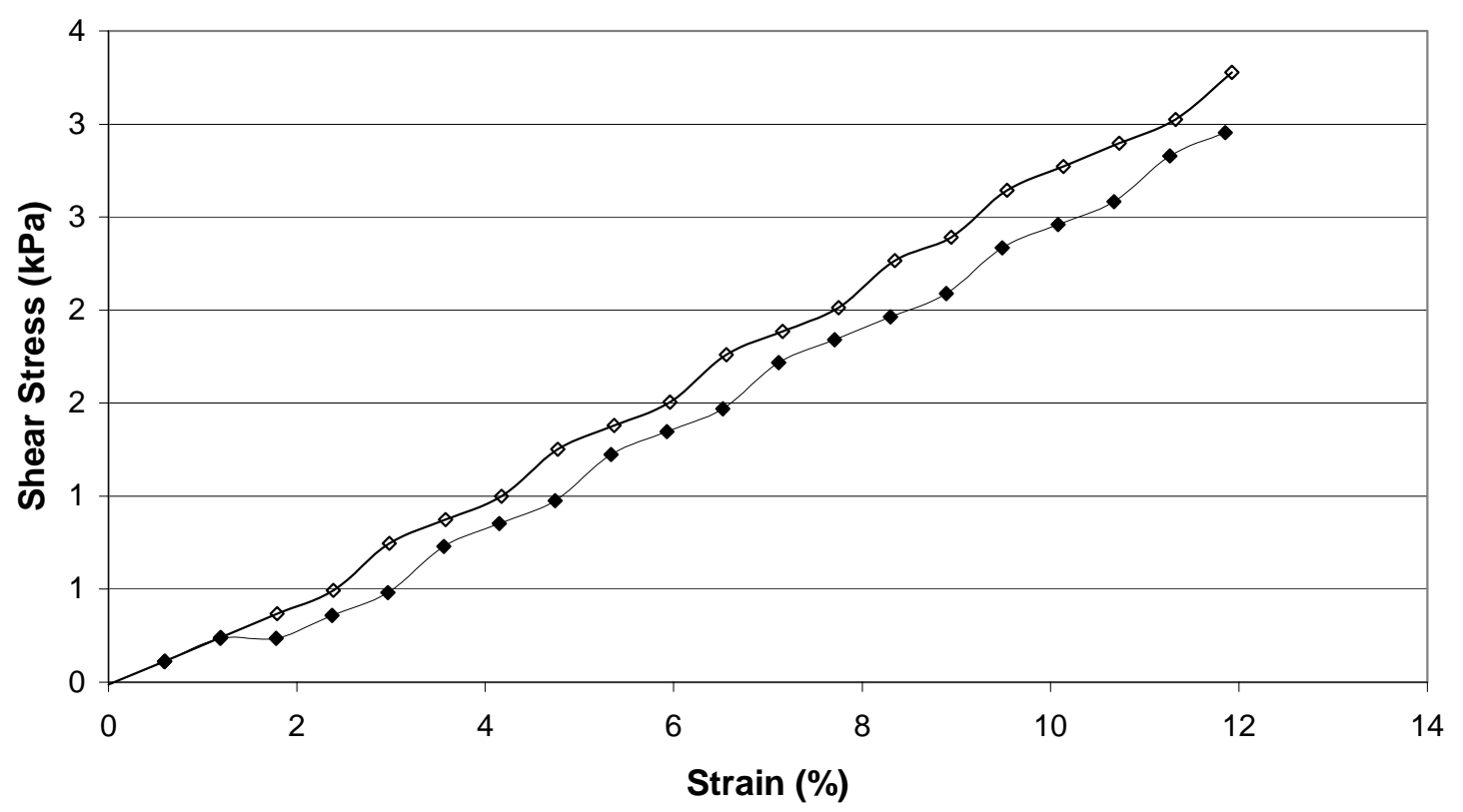

Figure 4.88: Pullout test results for material $\mathrm{C}$ - silt interface at $\mathrm{S}_{\mathrm{n}}=34.5 \mathrm{kPa}$ and $0 \%$ water content. 


\section{STRESS-STRAIN PULLOUT RELATIONSHIP}

\section{Material C-Silt Interface, $S_{\mathrm{n}}=69 \mathrm{kPa}, 0 \%$ Water Content}

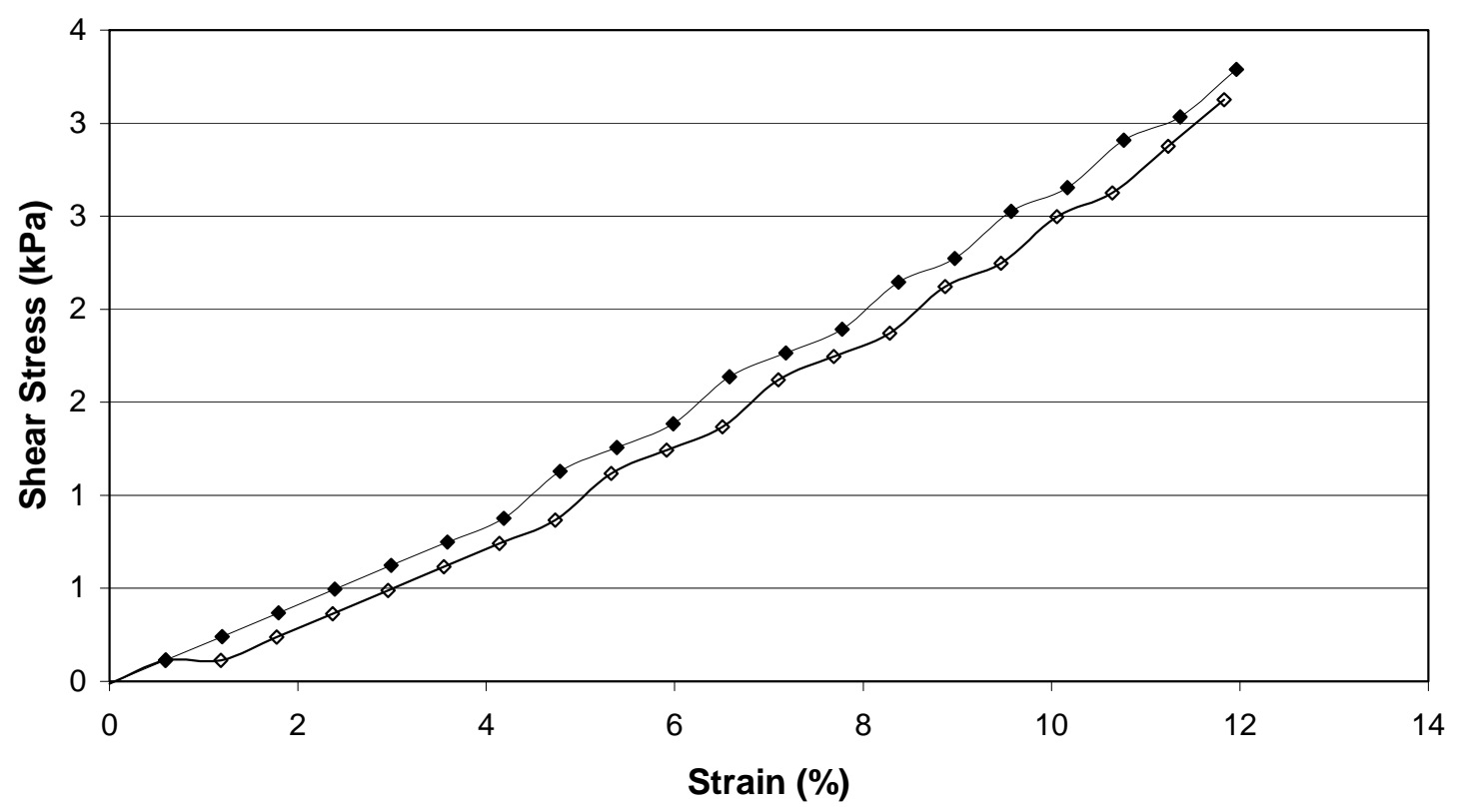

Figure 4.89: Pullout test results for material $C$ - silt interface at $S_{n}=69 \mathrm{kPa}$ and $0 \%$ water content. 
STRESS-STRAIN PULLOUT RELATIONSHIP

Material C-Silt Interface, $S_{n}=103.4 \mathrm{kPa}, 0 \%$ Water Content

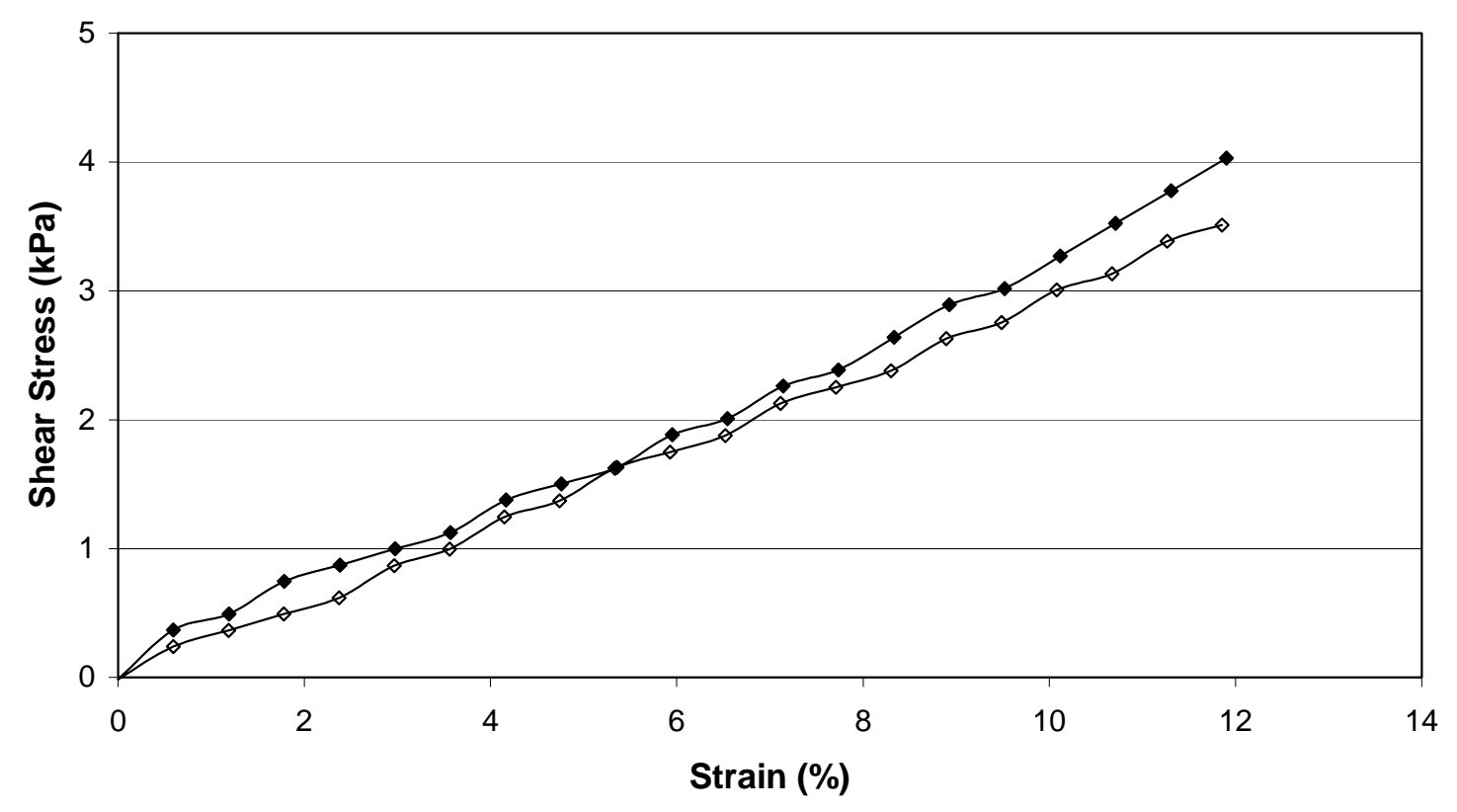

Figure 4.90: Pullout test results for material C - silt interface at $\mathrm{S}_{\mathrm{n}}=103.4 \mathrm{kPa}$ and $0 \%$ water content. 


\section{PULLOUT FAILURE ENVELOPE}

Material C-Silt Interface, 0\% Water Content

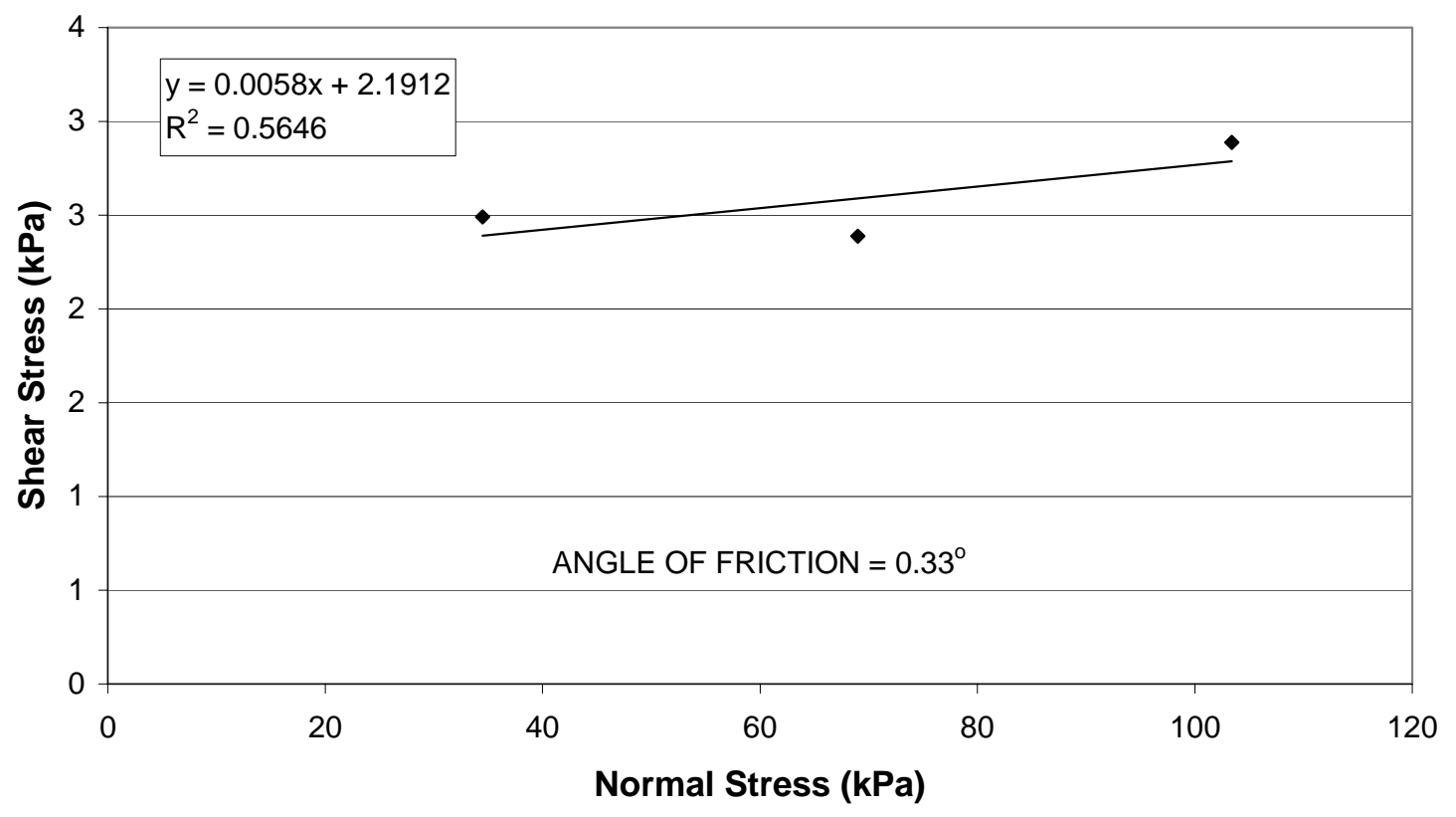

Figure 4.91: Pullout failure envelope for material C - silt interface at $0 \%$ water content. 
Figures 4.92, 4.93 and 4.94 show the pullout stress-strain relationship for material C-sand interface. Figure 4.95 illustrates the failure envelope for this interface. An angle of friction equal to 1.10 degrees and an effective cohesion equal to $1.0 \mathrm{kPa}$ was recorded.

\section{STRESS-STRAIN PULLOUT RELATIONSHIP Material C-Silt Interface, $S_{n}=\mathbf{3 4 . 5} \mathrm{kPa}, \mathbf{1 0} \%$ Water Content}

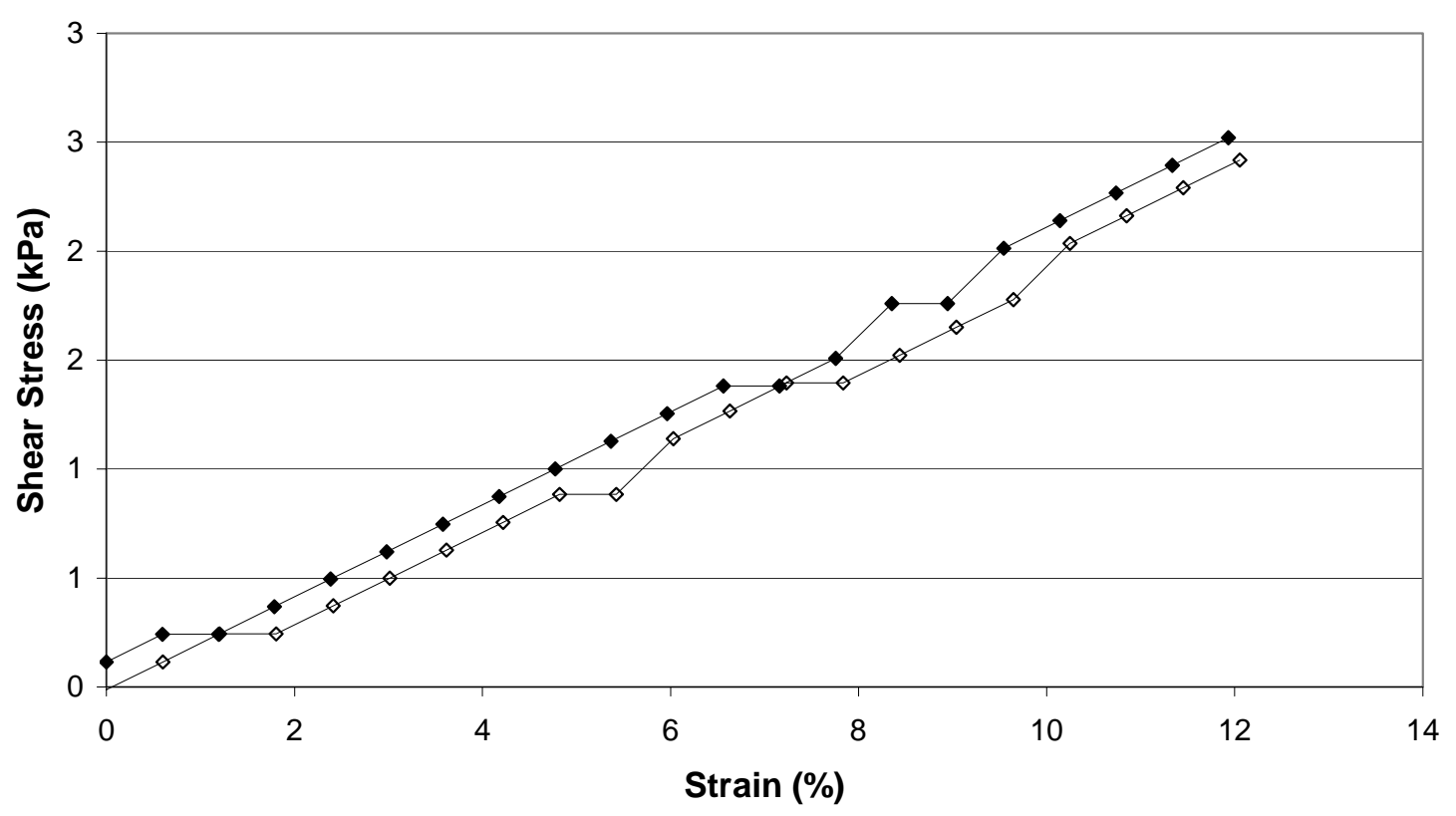

Figure 4.92: Pullout test results for material C - silt interface at $S_{n}=34.5 \mathrm{kPa}$ and $10 \%$ water content. 
STRESS-STRAIN PULLOUT RELATIONSHIP

\begin{abstract}
Material C-Silt Interface, $S_{n}=69 \mathrm{kPa}, 10 \%$ Water Content
\end{abstract}

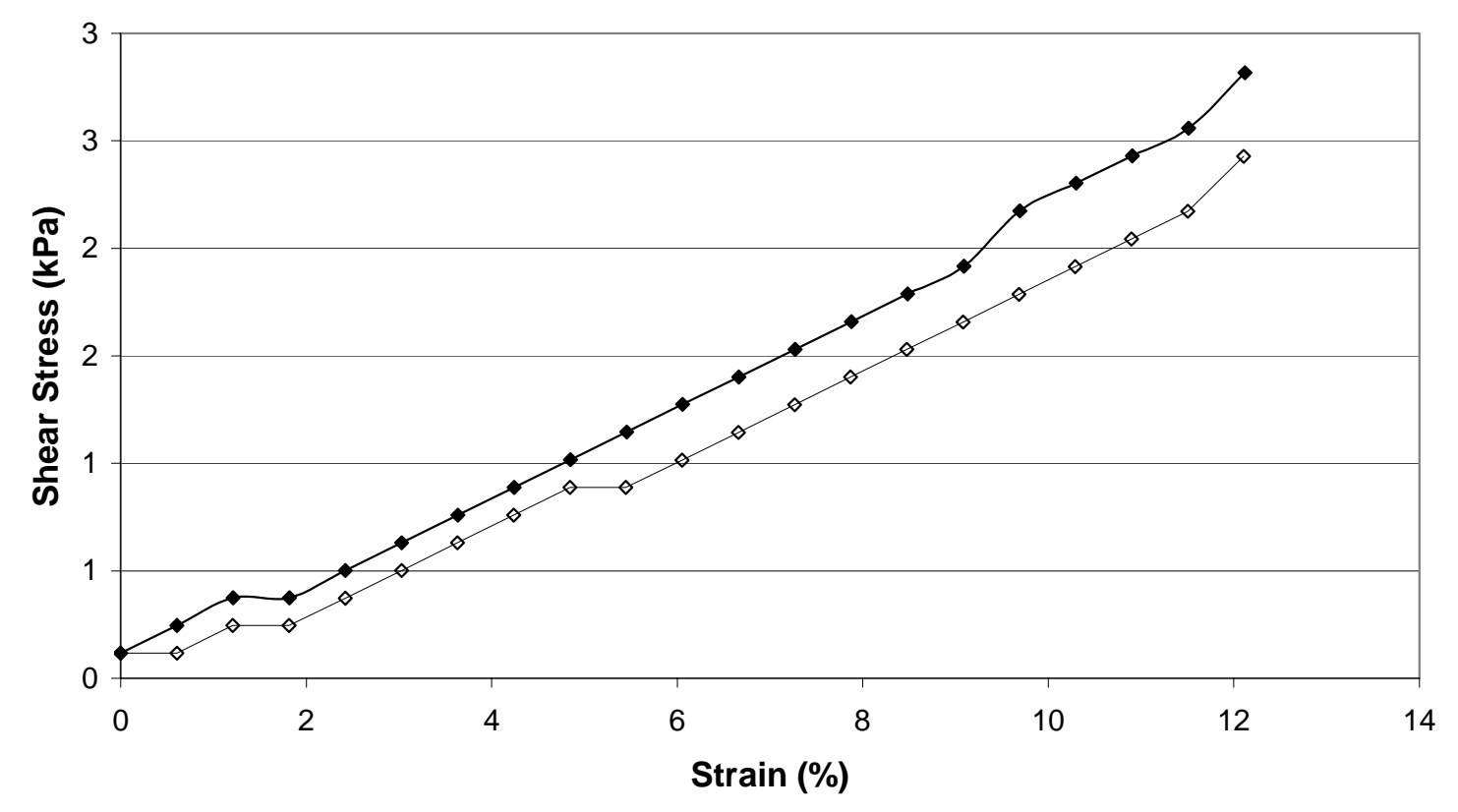

Figure 4.93: Pullout test results for material C - silt interface at $S_{n}=69 \mathrm{kPa}$ and $10 \%$ water content. 
STRESS-STRAIN PULLOUT RELATIONSHIP

Material C-Silt Interface, $S_{n}=103.4 \mathrm{kPa}, 10 \%$ Water Content

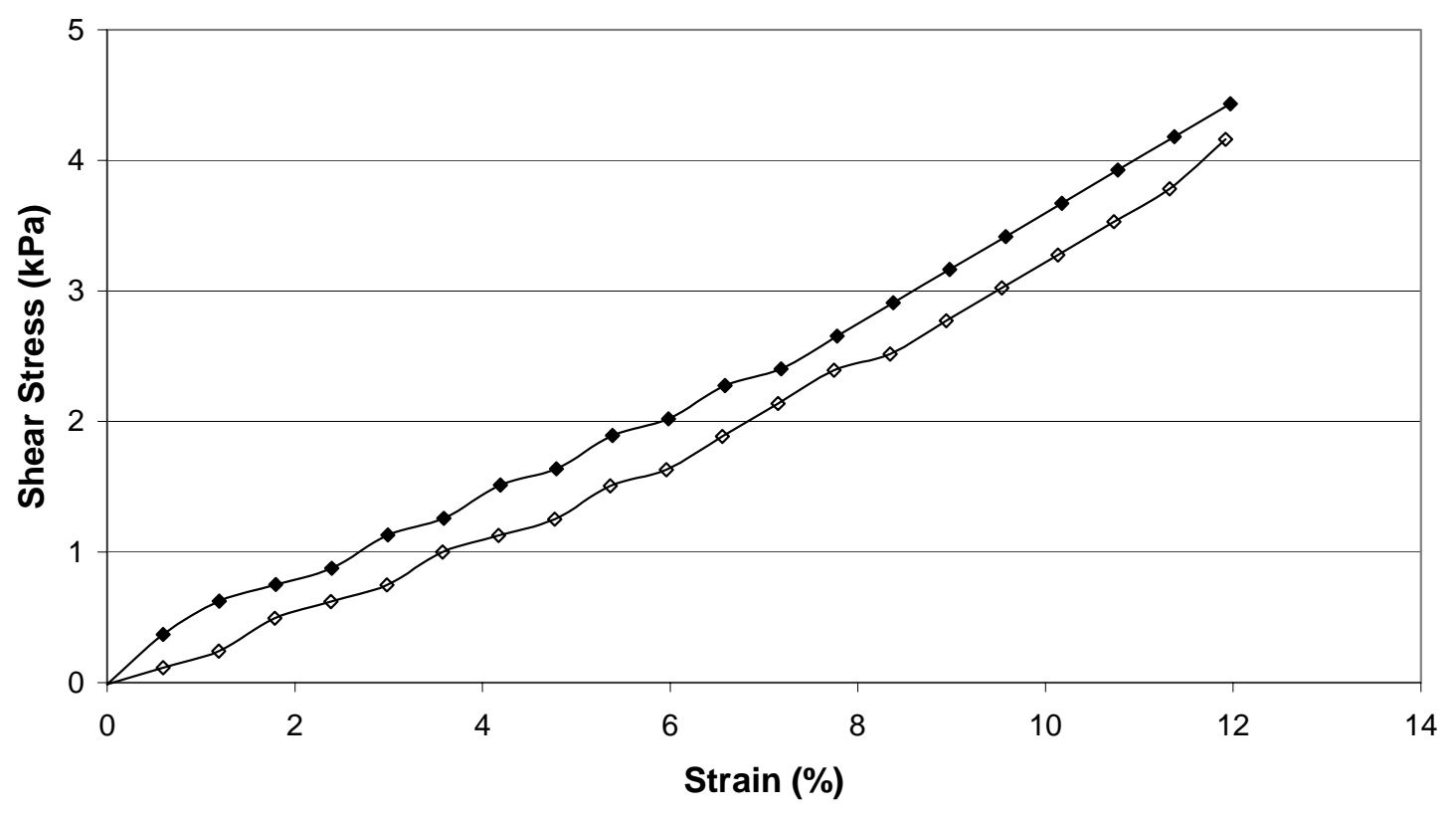

Figure 4.94: Pullout test results for material $\mathrm{C}$ - silt interface at $S_{\mathrm{n}}=103.4 \mathrm{kPa}$ and $10 \%$ water content. 


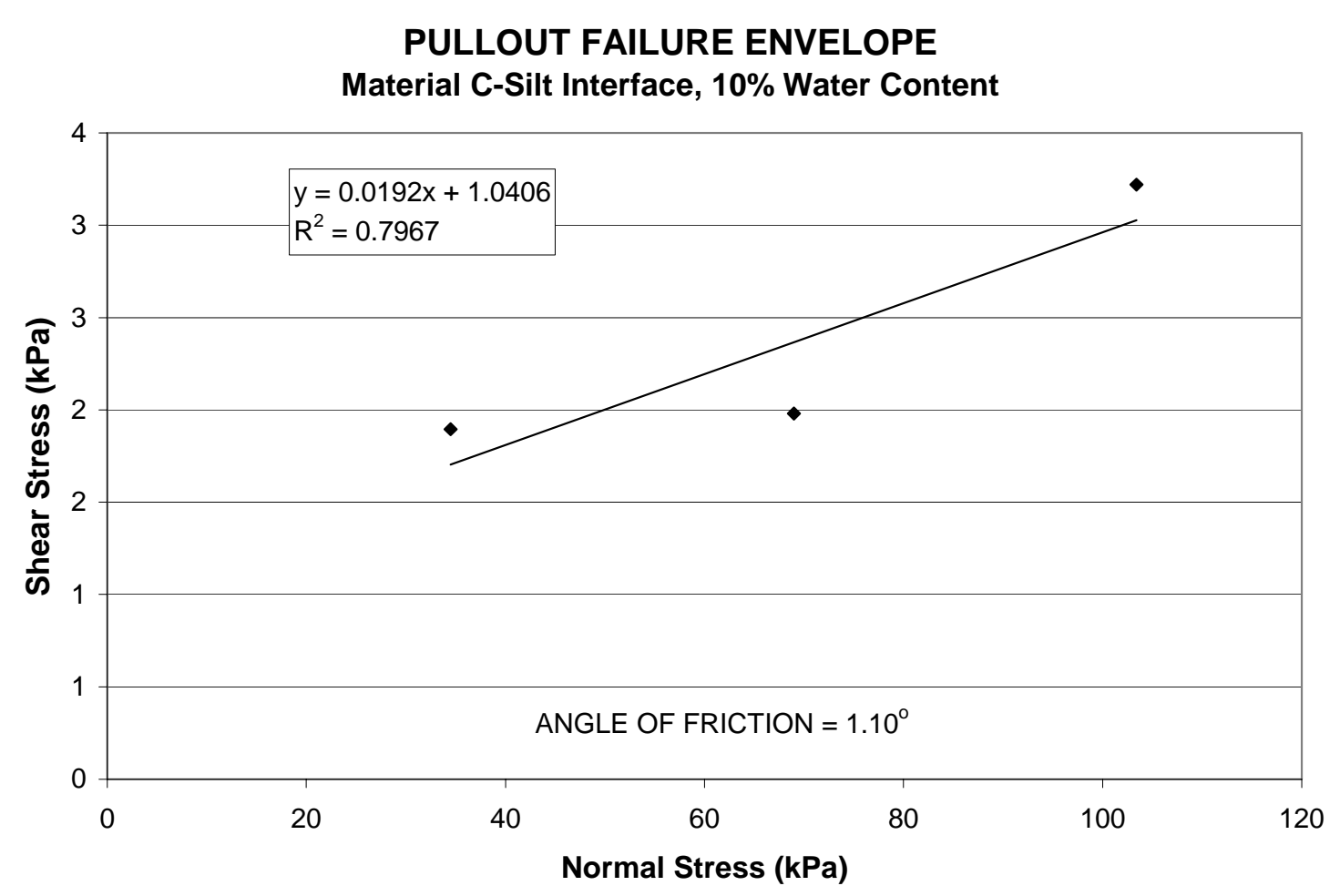

Figure 4.95: Pullout failure envelope for material C - silt interface at $10 \%$ water content. 
In the following three figures, Figure 4.96, 4.97 and 4.98, the pullout stress-strain relationship for material C-sand is presented. An angle of friction equal to 0.29 degrees is shown in Figure 4.99. This figure illustrates the failure envelope for the interface and shows an effective cohesion of $2.1 \mathrm{kPa}$.

\section{STRESS-STRAIN PULLOUT RELATIONSHIP Material C-Silt Interface, $S_{n}=34.5 \mathrm{kPa}, 15 \%$ Water Content}

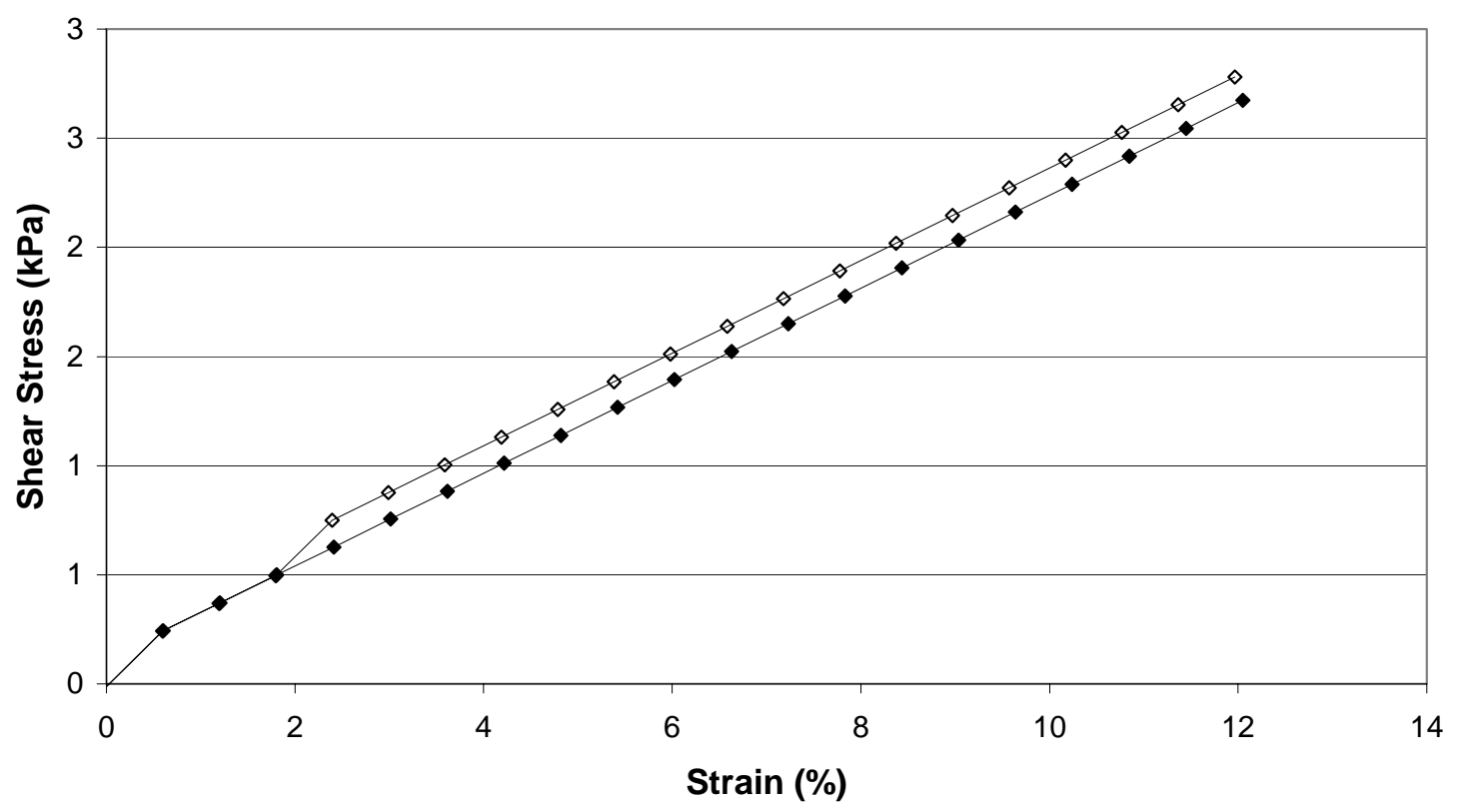

Figure 4.96: Pullout test results for material C - silt interface at $\mathrm{S}_{\mathrm{n}}=34.5 \mathrm{kPa}$ and $15 \%$ water content. 
STRESS-STRAIN PULLOUT RELATIONSHIP

\begin{abstract}
Material C-Silt Interface, $S_{n}=69 \mathrm{kPa}, 15 \%$ Water Content
\end{abstract}

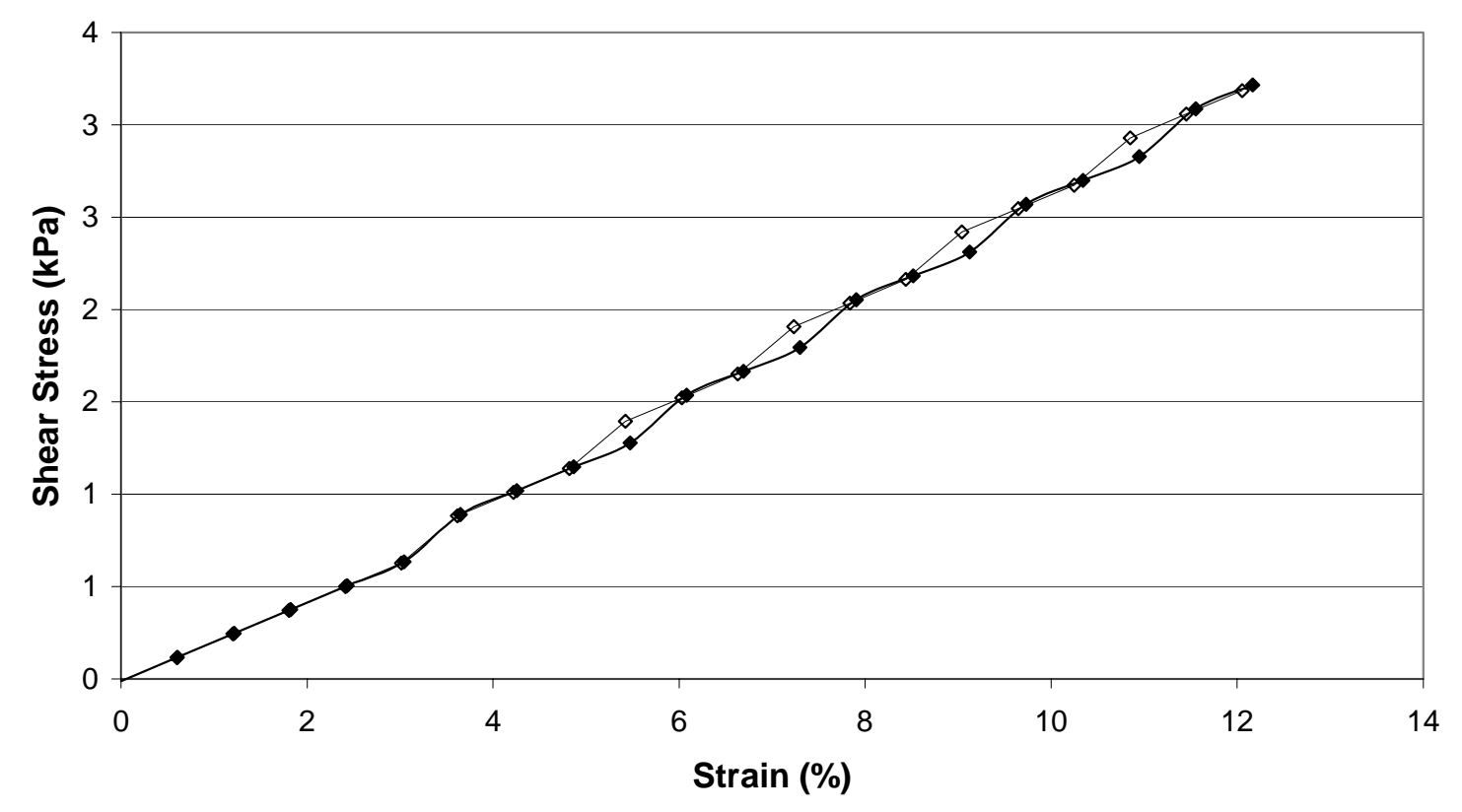

Figure 4.97: Pullout test results for material C - silt interface at $S_{n}=69 \mathrm{kPa}$ and $15 \%$ water content. 
STRESS-STRAIN PULLOUT RELATIONSHIP

Material C-Silt Interface, $S_{\mathrm{n}}=103.4 \mathrm{kPa}, \mathbf{1 5} \%$ Water Content

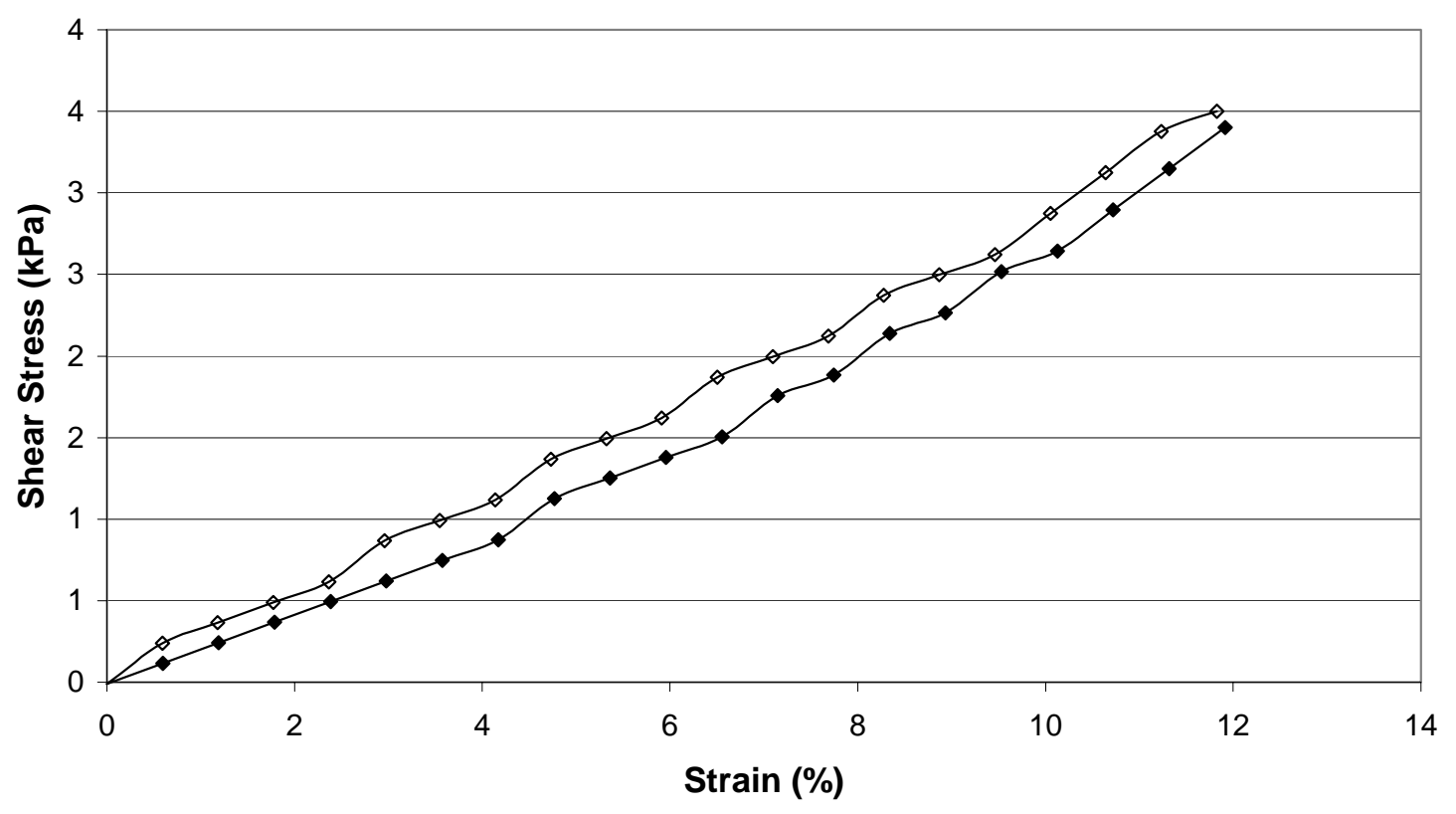

Figure 4.98: Pullout test results for material $\mathrm{C}$ - silt interface at $S_{n}=103.4 \mathrm{kPa}$ and $15 \%$ water content. 


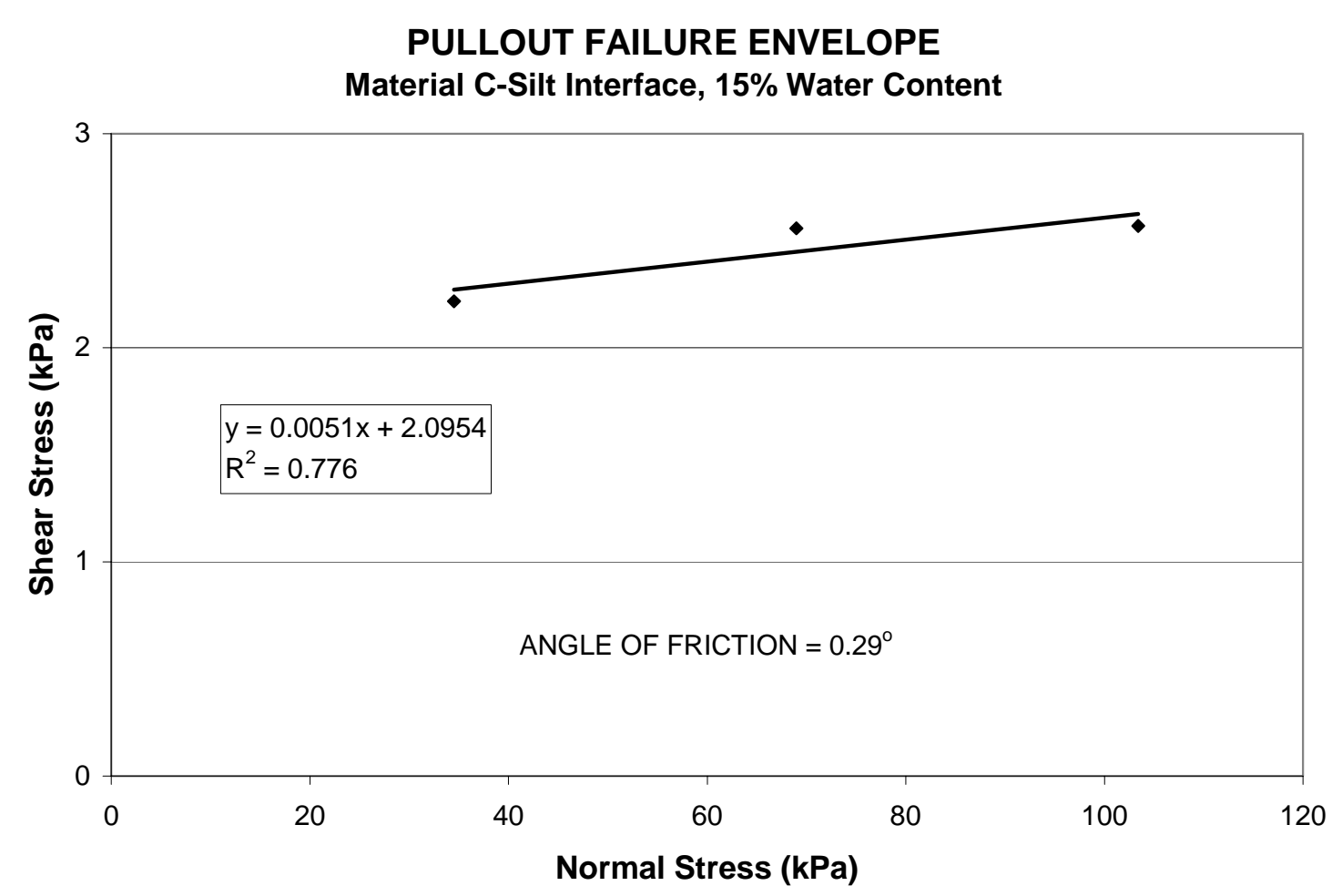

Figure 4.99: Pullout failure envelope for material C - silt interface at $15 \%$ water content. 
Figure 4.100, 4.101, and 4.102 shows the pullout shear stress-strain relationships for the interface consisting of material B and sand. The pullout failure envelope for this interface is shown in Figure 4.103. This figure illustrates an angle of friction equal to 4.6 degrees and an effective cohesion of $7.4 \mathrm{kPa}$.

STRESS-STRAIN PULLOUT RELATIONSHIP Material B-Clay Interface, $\mathrm{S}_{\mathrm{n}}=\mathbf{3 4 . 5} \mathrm{kPa}, \mathbf{0} \%$ Water Content

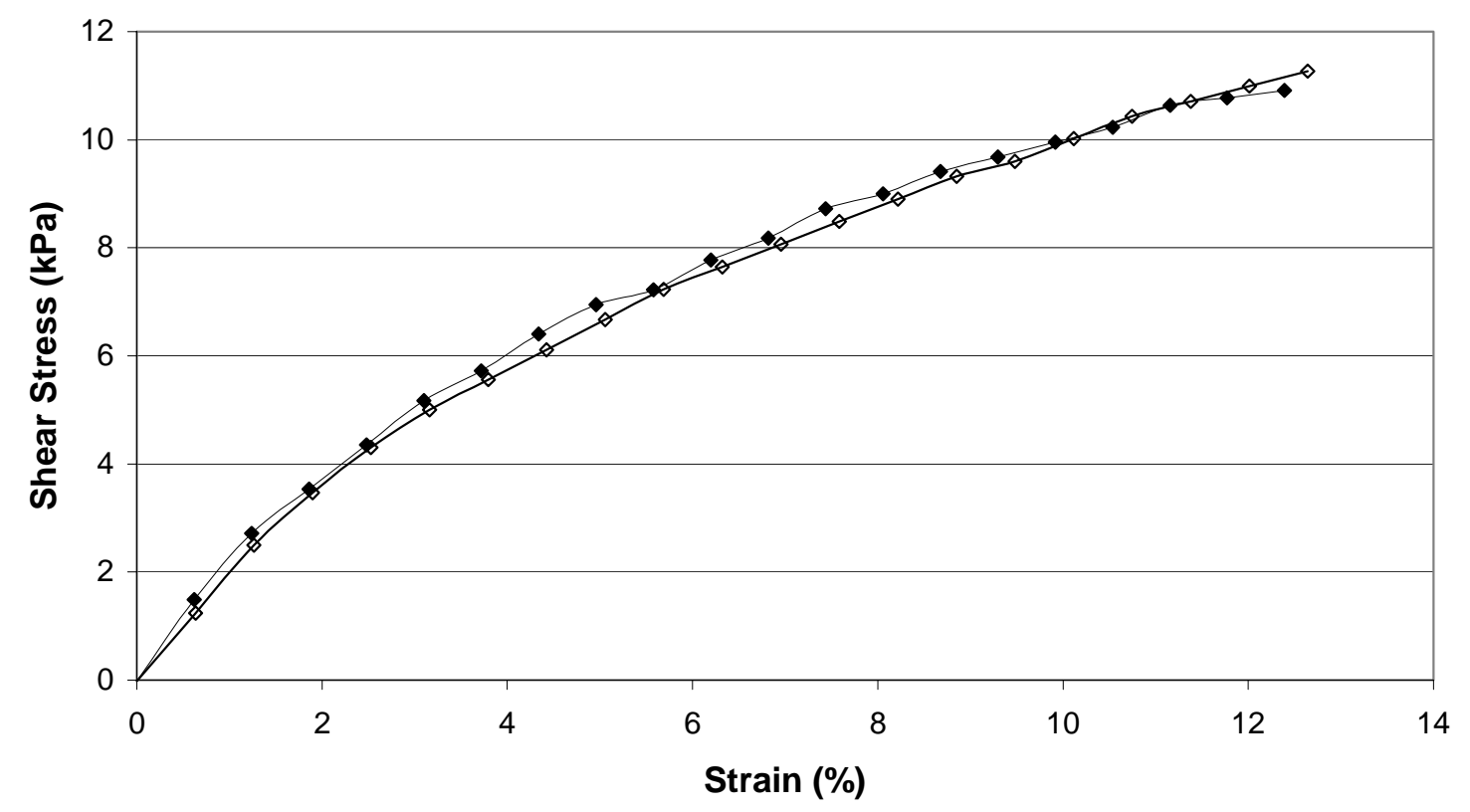

Figure 4.100: Pullout test results for material B - clay interface at $\sigma_{\mathrm{n}}=34.5 \mathrm{kPa}$ and $0 \%$ water content. 
STRESS-STRAIN PULLOUT RELATIONSHIP

Material B-Clay Interface, $S_{n}=69 \mathrm{kPa}, 0 \%$ Water Content

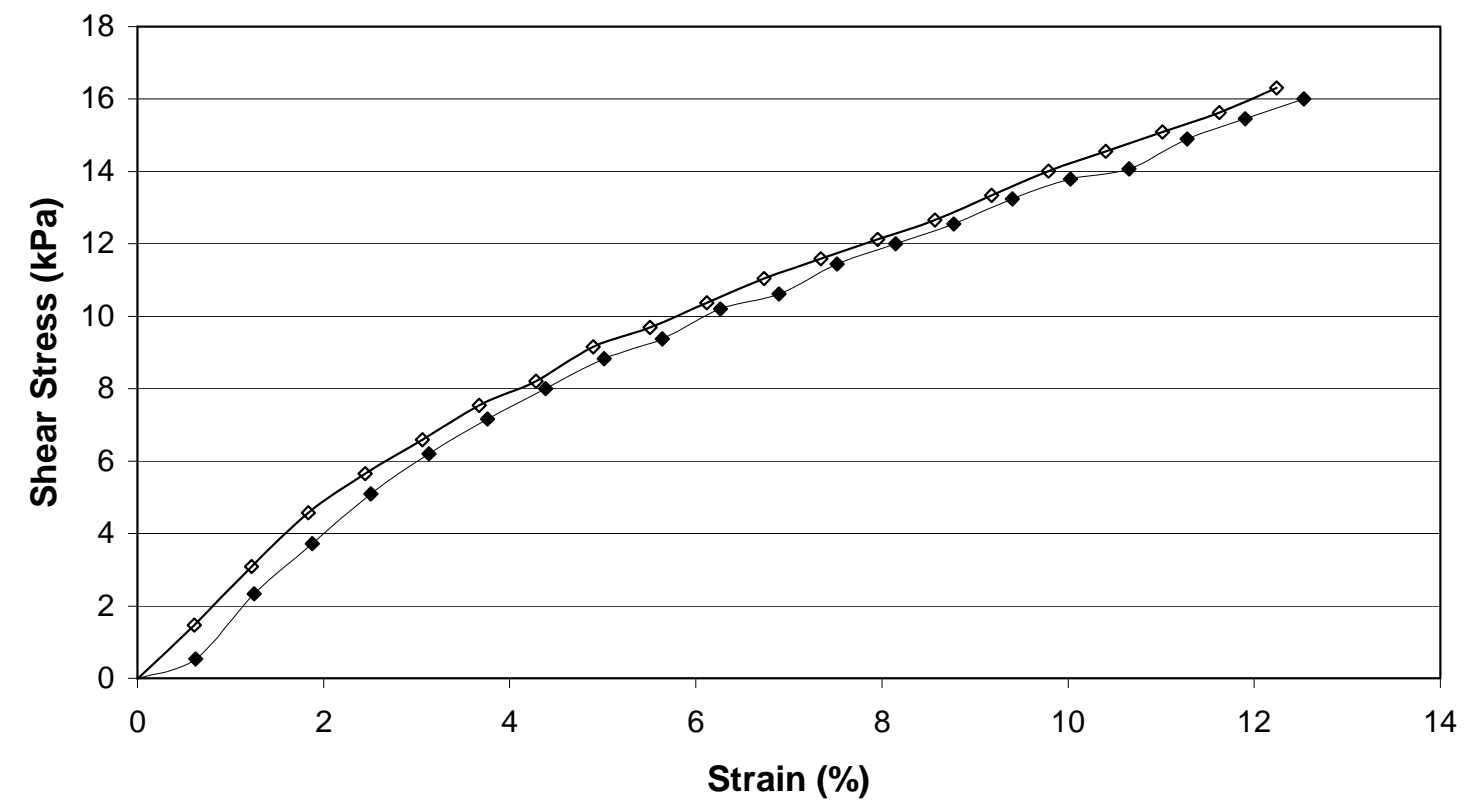

Figure 4.101: Pullout test results for material B - clay interface at $\sigma_{\mathrm{n}}=69 \mathrm{kPa}$ and $0 \%$ water content. 
STRESS-STRAIN PULLOUT RELATIONSHIP

Material B-Clay Interface, $S_{n}=103.4 \mathrm{kPa}, 0 \%$ Water Content

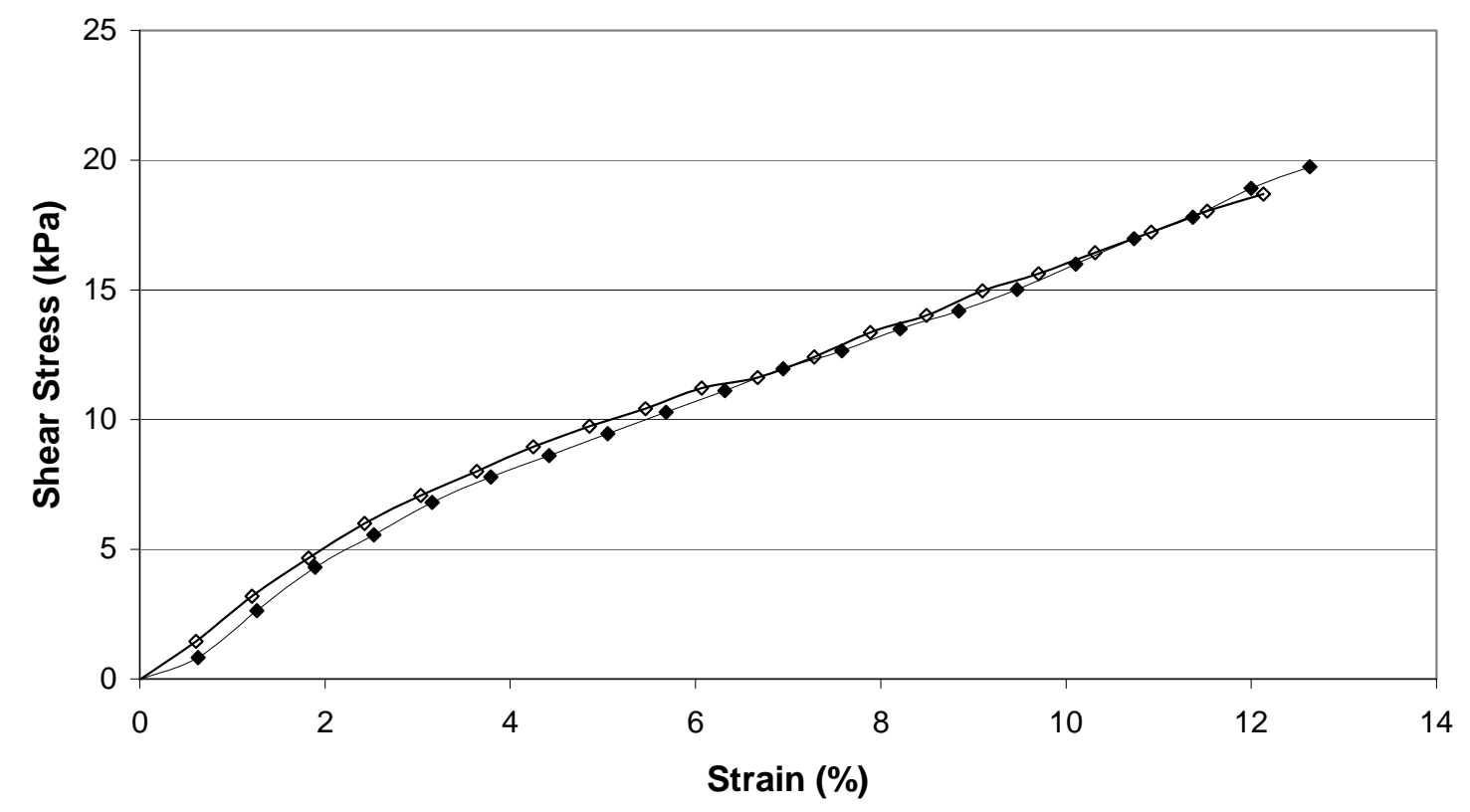

Figure 4.102: Pullout test results for material B - clay interface at $\sigma_{\mathrm{n}}=103.4 \mathrm{kPa}$ and $0 \%$ water content. 
PULLOUT FAILURE ENVELOPE Material B-Clay Interface, 0\% Water Content

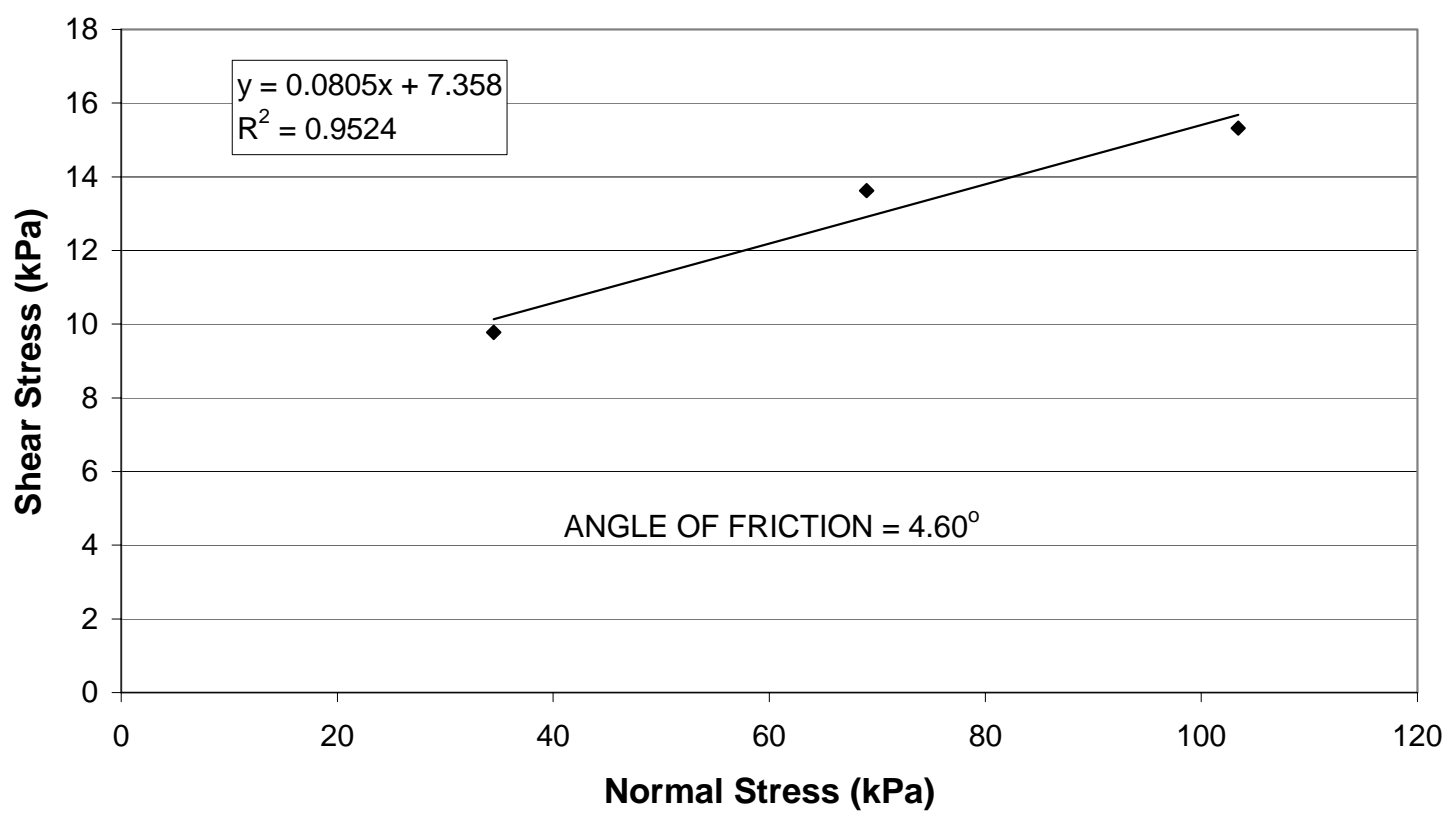

Figure 4.103: Pullout failure envelope for material B - clay at $0 \%$ water content. 
Figures 4.104, 4.105 and 4.106 show the pullout stress-strain relationship for material B-sand interface. Figure 4.107 illustrates the failure envelope for this interface. An angle of friction equal to 1.94 degrees and an effective cohesion equal to $9.9 \mathrm{kPa}$ was recorded.

STRESS-STRAIN PULLOUT RELATIONSHIP Material B - Clay Interface, $S_{n}=34.5 \mathrm{kPa}, 10 \%$ Water Content

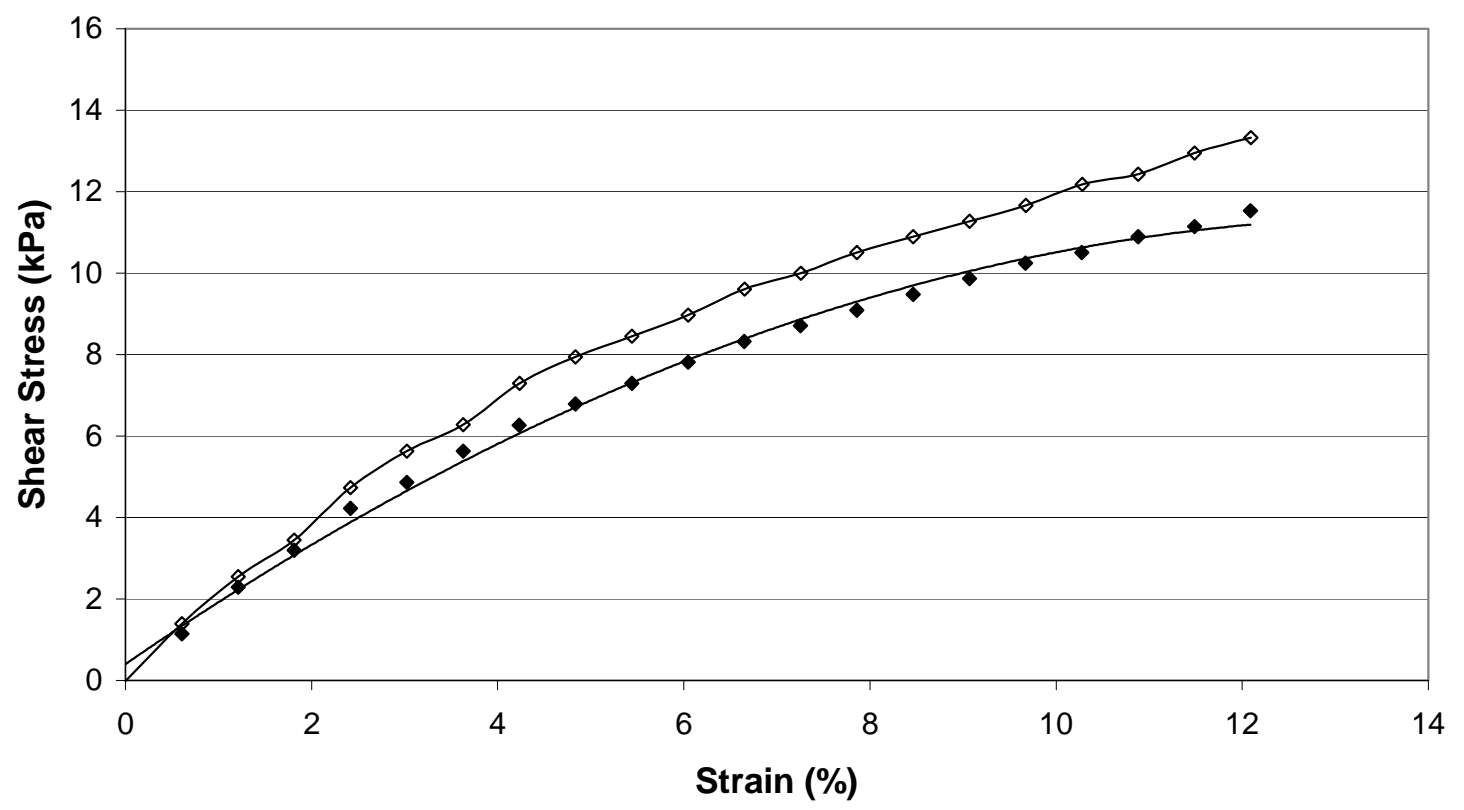

Figure 4.104: Pullout test results for material B - clay interface at $\sigma_{\mathrm{n}}=34.5 \mathrm{kPa}$ and $10 \%$ water content. 
STRESS-STRAIN PULLOUT RELATIONSHIP

Material B - Clay Interface, $S_{n}=69 \mathrm{kPa}, 10 \%$ Water Content

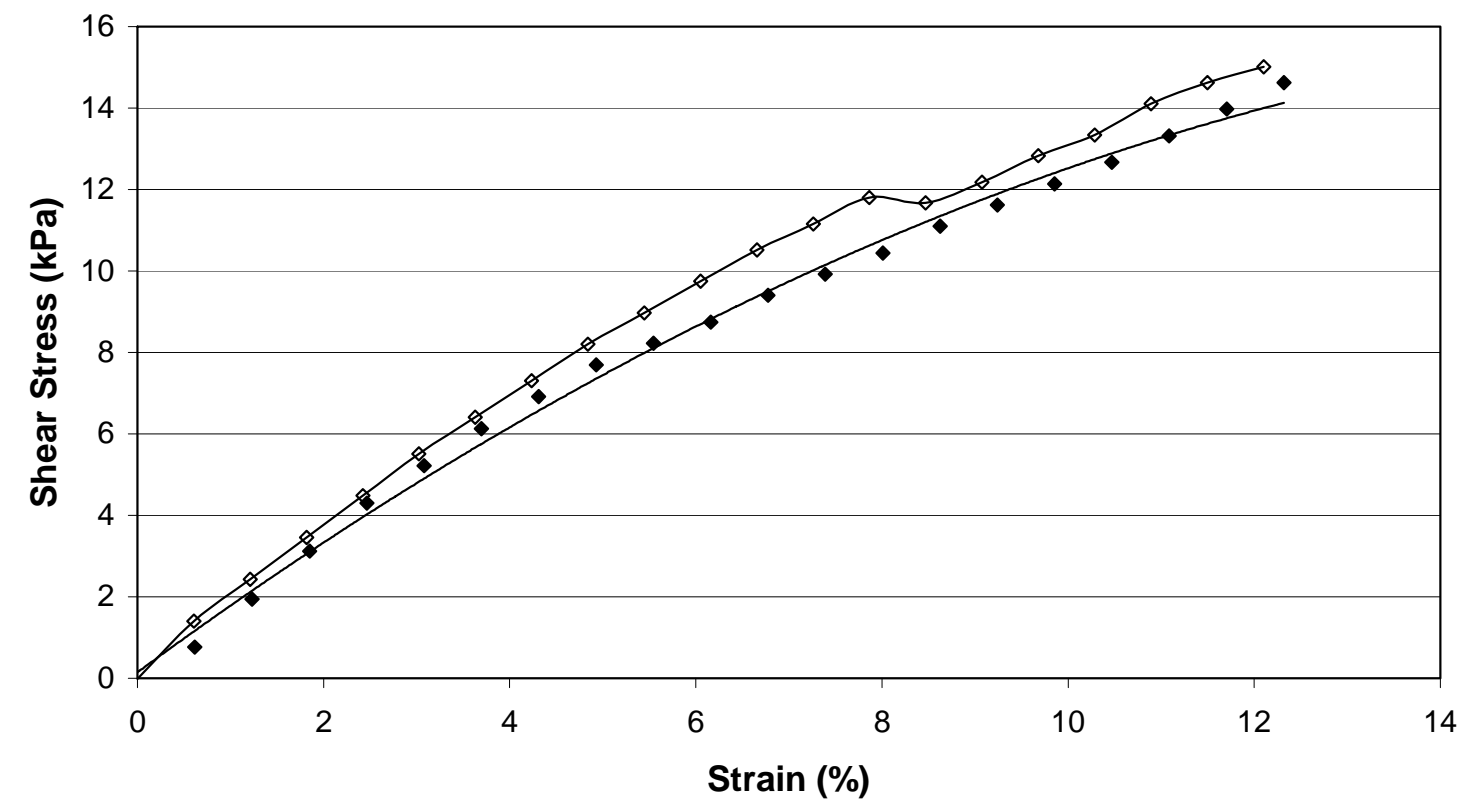

Figure 4.105: Pullout test results for material $\mathrm{B}$ - clay interface at $\sigma_{\mathrm{n}}=69 \mathrm{kPa}$ and $10 \%$ water content. 
STRESS-STRAIN PULLOUT RELATIONSHIP

Material B - Clay Interface, $S_{n}=103.4 \mathrm{kPa}, 10 \%$ Water Content

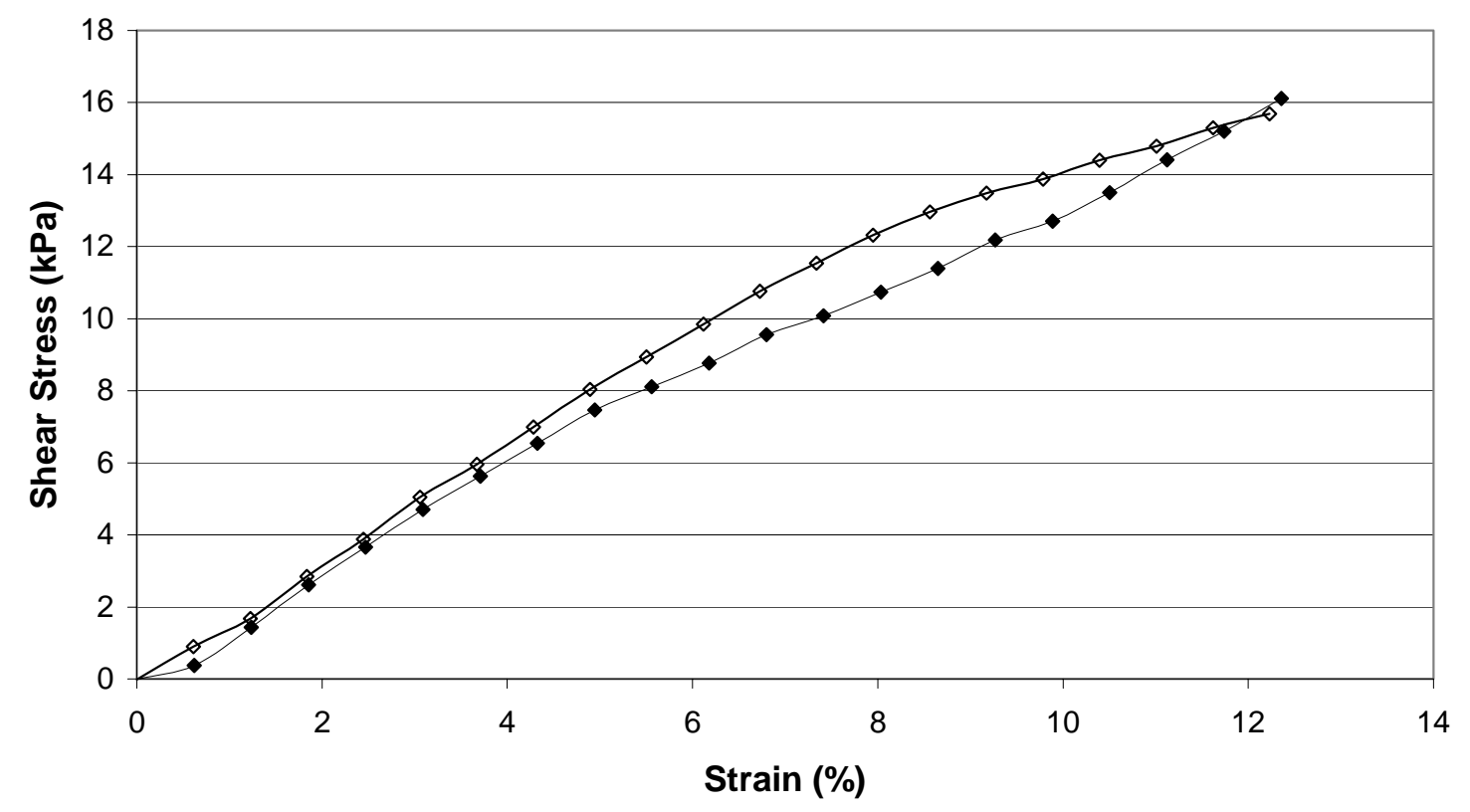

Figure 4.106: Pullout test results for material $B$ - clay interface at $\sigma_{\mathrm{n}}=103.4 \mathrm{kPa}$ and $10 \%$ water content. 
PULLOUT FAILURE ENVELOPE Material B - Clay Interface, 10\% Water Content

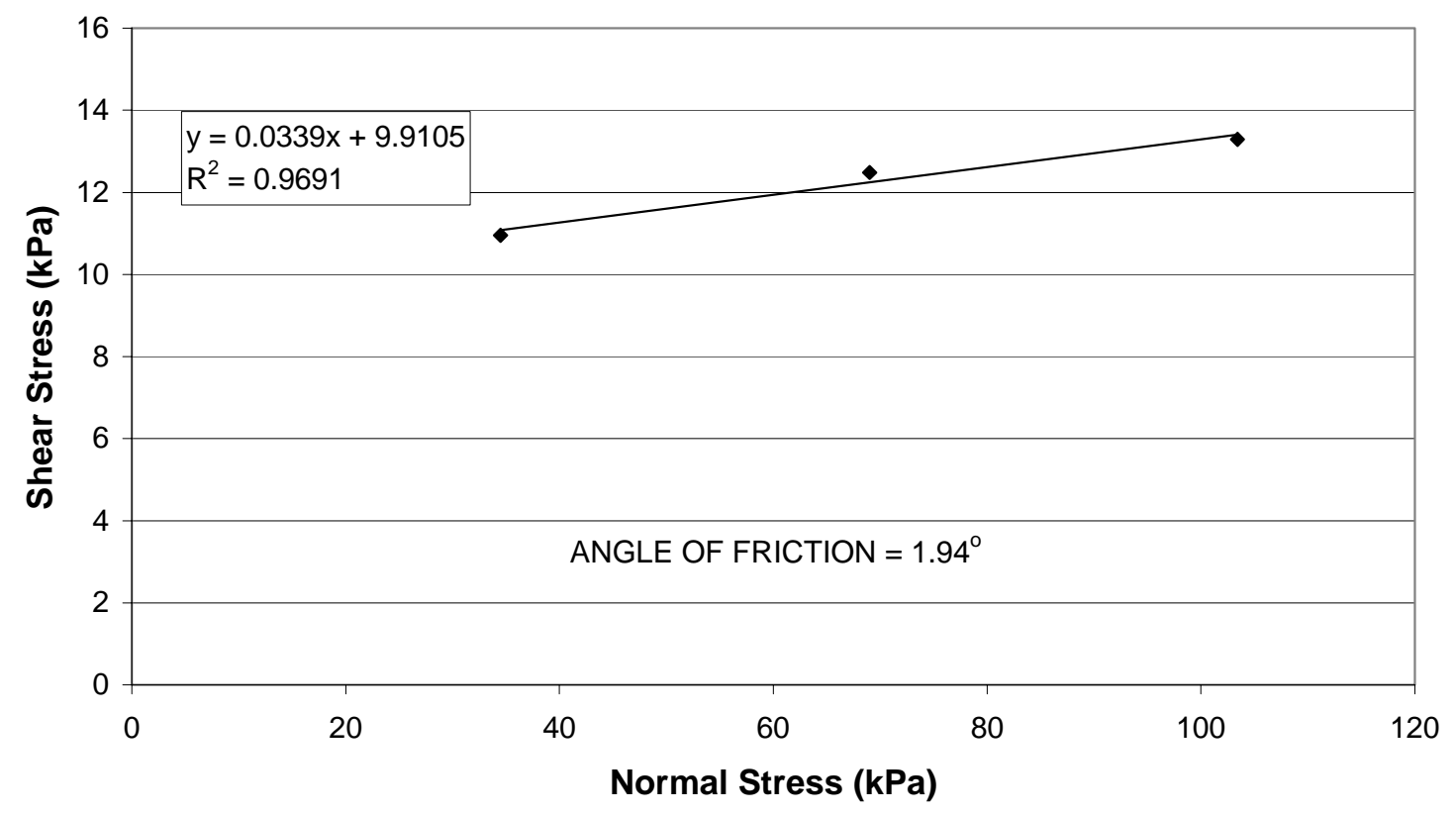

Figure 4.107: Pullout failure envelope for material B - clay interface at $10 \%$ water content. 
In the following three figures, Figure 4.108, 4.109 and 4.110, the pullout stressstrain relationship for material B-sand is presented. An angle of friction equal to 1.01 degrees is shown in Figure 4.111. This figure illustrates the failure envelope for the interface and shows an effective cohesion of $9.4 \mathrm{kPa}$.

STRESS-STRAIN PULLOUT RELATIONSHIP Material B - Clay Interface, $S_{n}=34.5 \mathrm{kPa}, 15 \%$ Water Content

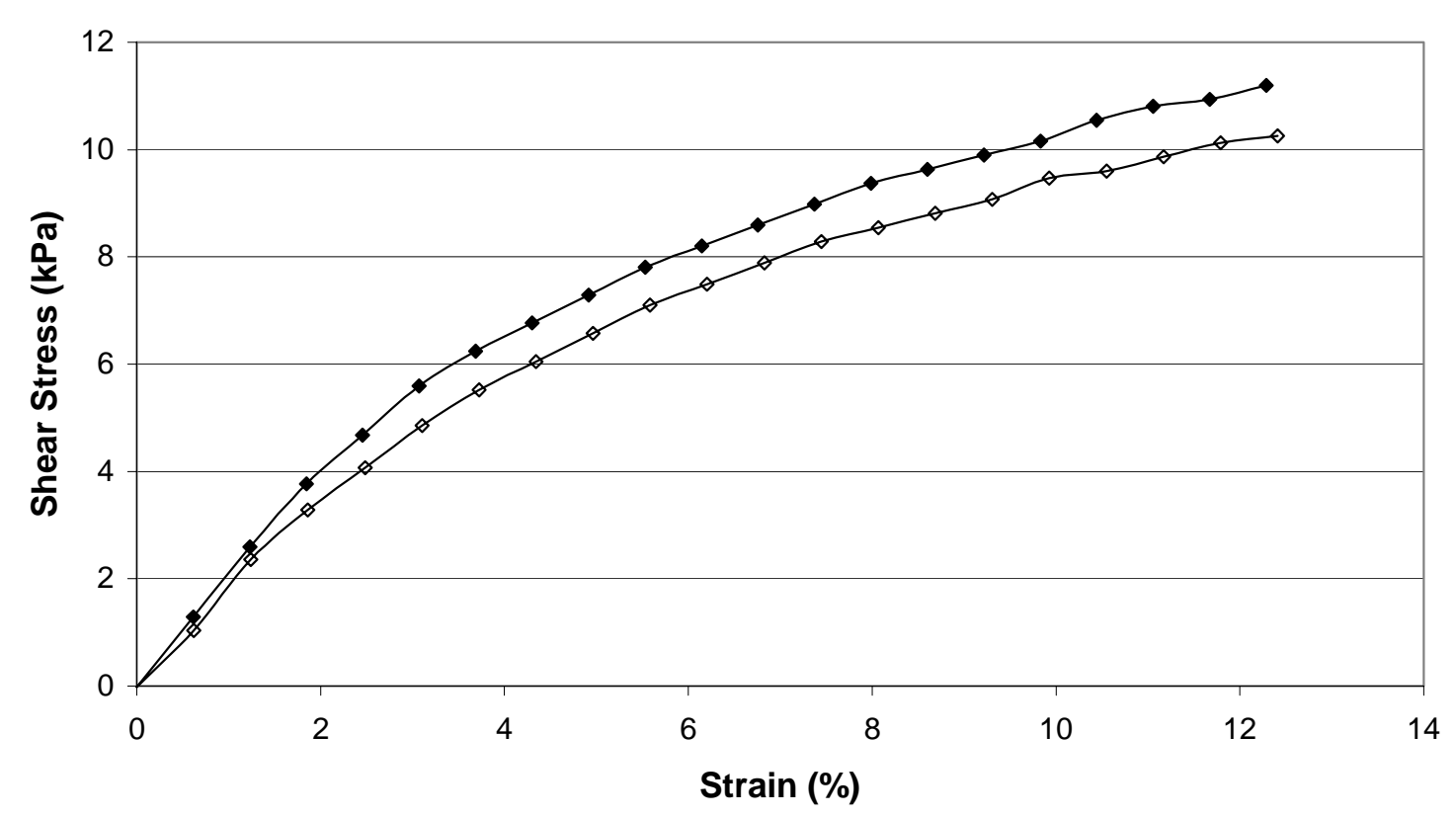

Figure 4.108: Pullout test results for material B - clay interface at $\sigma_{\mathrm{n}}=34.5 \mathrm{kPa}$ and $15 \%$ water content. 
STRESS-STRAIN PULLOUT RELATIONSHIP

Material B - Clay Interface, $S_{n}=69 \mathrm{kPa}, 15 \%$ Water Content

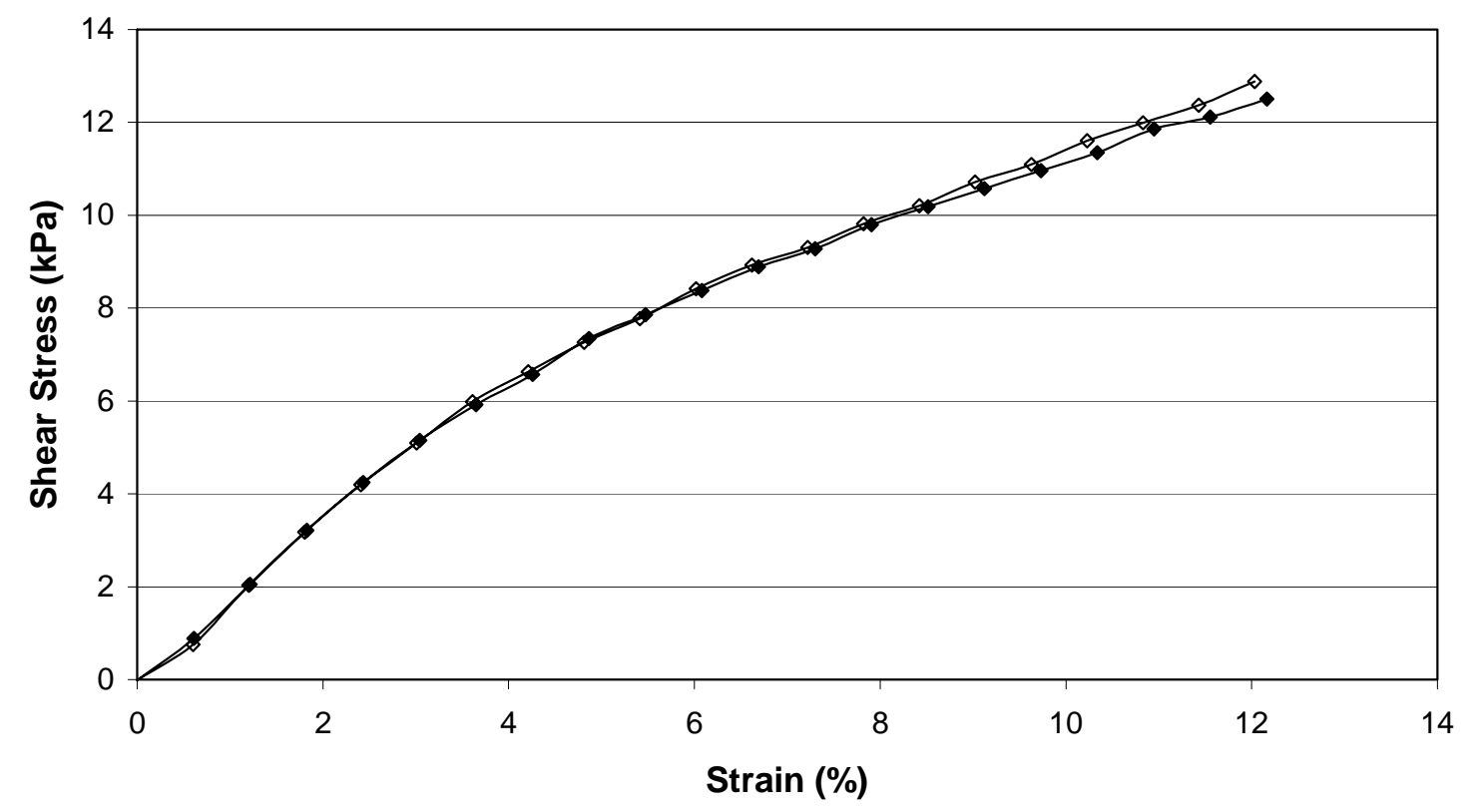

Figure 4.109: Pullout test results for material $B$ - clay interface at $\sigma_{\mathrm{n}}=69 \mathrm{kPa}$ and $15 \%$ water content. 
STRESS-STRAIN PULLOUT RELATIONSHIP

Material B - Clay Interface, $S_{n}=103.4 \mathrm{kPa}, 15 \%$ Water Content

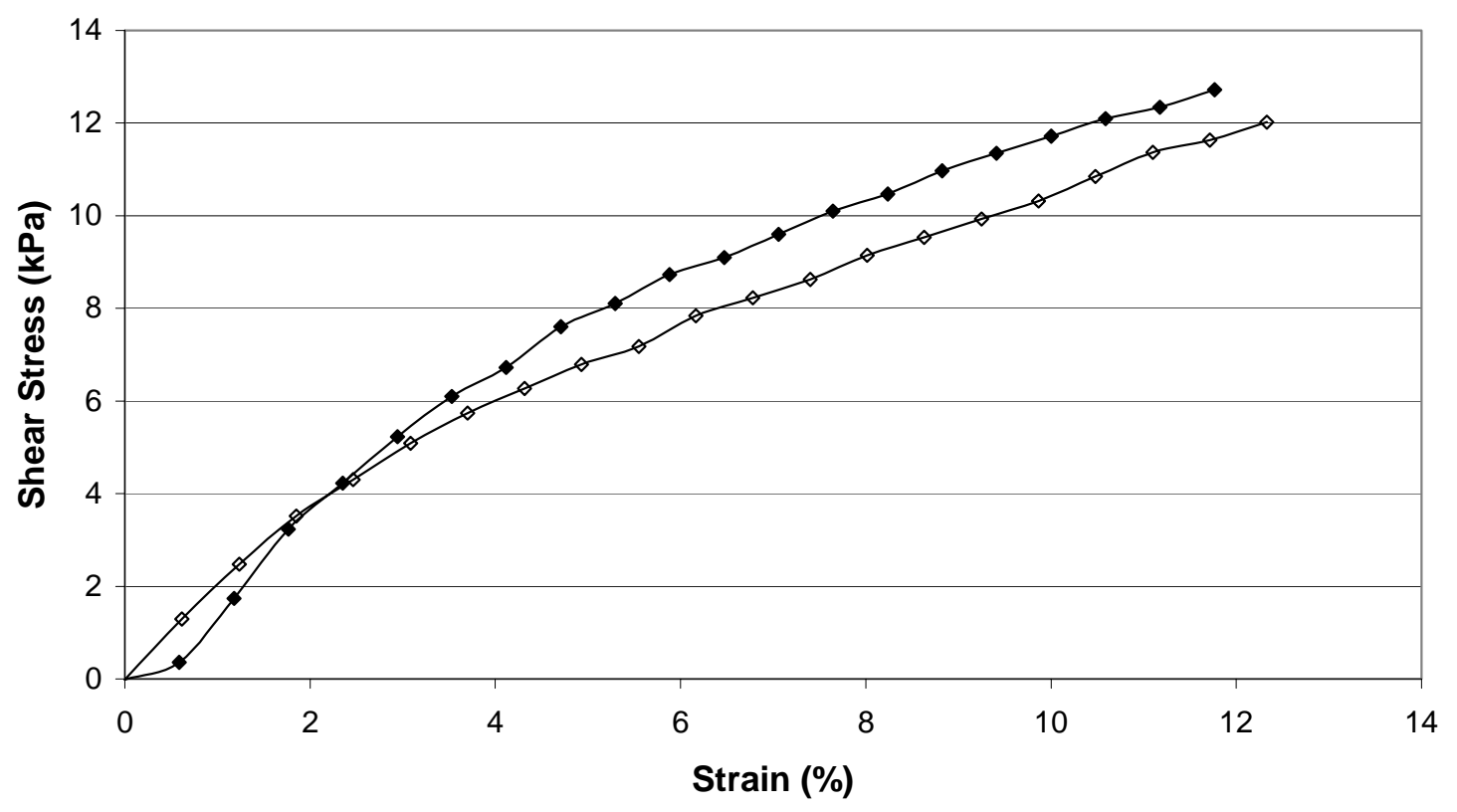

Figure 4.110: Pullout test results for material B - clay interface at $\sigma_{\mathrm{n}}=103.4 \mathrm{kPa}$ and $15 \%$ water content. 
PULLOUT FAILURE ENVELOPE Material B - Clay Interface, 15\% Water Content

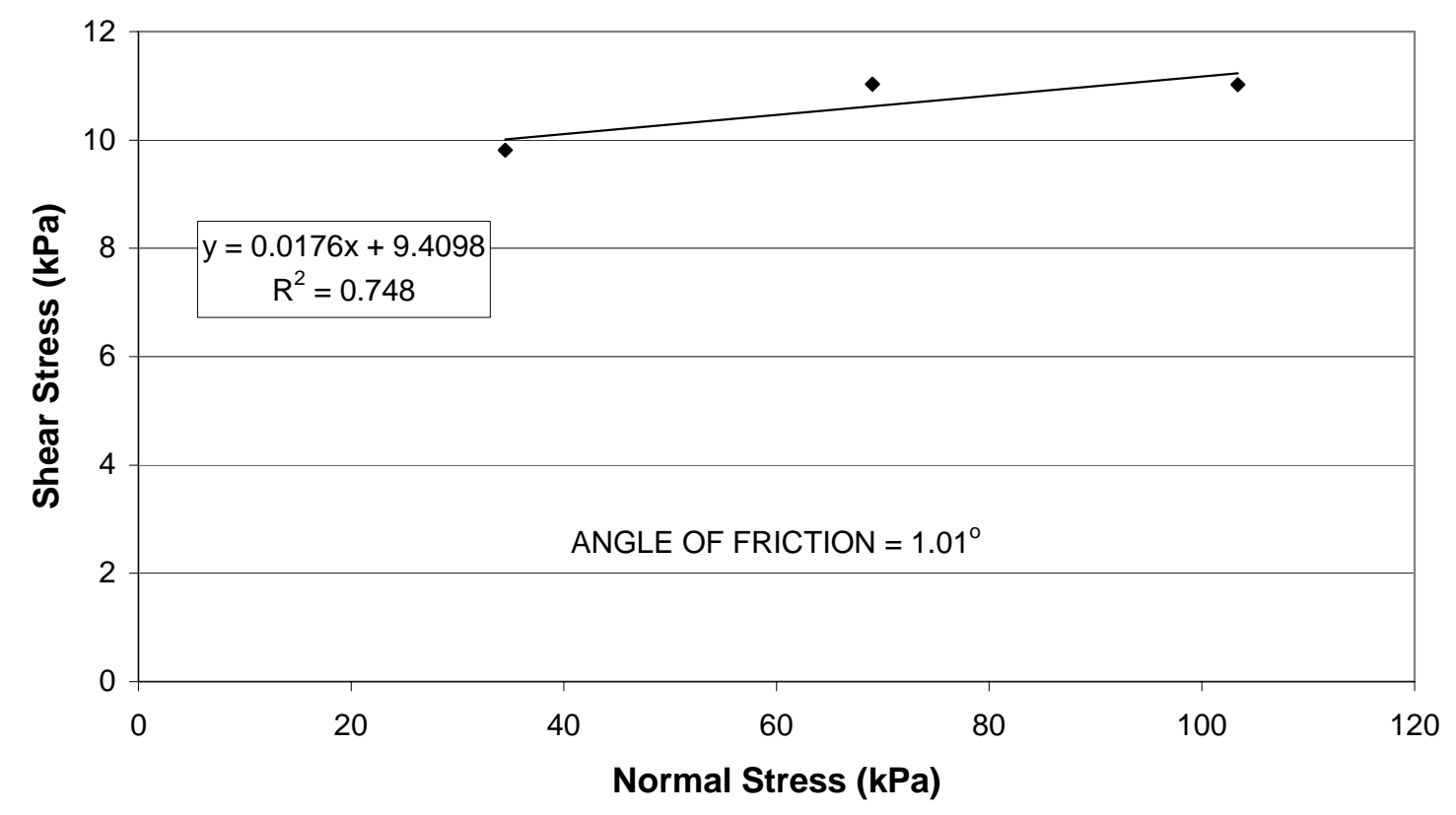

Figure 4.111: Pullout failure envelope for material B - clay interface at $15 \%$ water content.

Table 4.2 shows a summary of pullout test results and geosynthetic material properties. The results include angles of friction and effective cohesions. As seen from this table the angles of friction decrease as the tensile strength of the geosynthetic decreases. It is also noted that the angles of friction decrease as the percentage of clay in the soil increases. 
Table 4.2: Summary of pullout test results and geosynthetic material properties.

\begin{tabular}{|c|c|c|c|c|c|c|c|c|}
\hline $\begin{array}{c}\text { Geosynthetic } \\
\text { Material }\end{array}$ & $\begin{array}{c}\text { Tensile } \\
\text { Strength } \\
(\mathrm{kN} / \mathrm{m})\end{array}$ & $\begin{array}{c}\text { Grid } \\
\text { Aperture } \\
\text { Size, MD } \\
\text { (mm) }\end{array}$ & $\begin{array}{c}\text { Grid } \\
\text { Aperture } \\
\text { Size, XMD } \\
\text { (mm) }\end{array}$ & $\begin{array}{c}\text { Mass per } \\
\text { Unit Area } \\
\left(\mathrm{g} / \mathrm{m}^{2}\right)\end{array}$ & $\begin{array}{l}\text { Soil } \\
\text { Type }\end{array}$ & $\begin{array}{c}\text { Water } \\
\text { Content } \\
(\%)\end{array}$ & $\begin{array}{l}\text { Angle of } \\
\text { Friction } \\
\text { (degrees) }\end{array}$ & $\begin{array}{c}\text { Effective } \\
\text { Cohesion } \\
\quad(\mathrm{kPa})\end{array}$ \\
\hline \multirow{4}{*}{$A$} & \multirow{4}{*}{120} & \multirow{4}{*}{65} & \multirow{4}{*}{20} & \multirow{4}{*}{415} & Sand & 0 & 26.01 & 0 \\
\hline & & & & & \multirow{3}{*}{ Silt } & 0 & 19.21 & 4.5 \\
\hline & & & & & & 10 & 15.46 & 3.9 \\
\hline & & & & & & 15 & 16.78 & 1.1 \\
\hline \multirow{7}{*}{$B$} & \multirow{7}{*}{35} & \multirow{7}{*}{40} & \multirow{7}{*}{25} & \multirow{7}{*}{170} & Sand & 0 & 12.21 & 0 \\
\hline & & & & & \multirow{3}{*}{ Silt } & 0 & 4.22 & 9.3 \\
\hline & & & & & & 10 & 5.00 & 7.4 \\
\hline & & & & & & 15 & 4.06 & 7.5 \\
\hline & & & & & \multirow{3}{*}{ Clay } & 0 & 4.60 & 7.4 \\
\hline & & & & & & 10 & 1.94 & 9.9 \\
\hline & & & & & & 15 & 1.01 & 9.4 \\
\hline \multirow{4}{*}{ C } & \multirow{4}{*}{0.36} & \multirow{4}{*}{$\mathrm{N} / \mathrm{A}$} & \multirow{4}{*}{$\mathrm{N} / \mathrm{A}$} & \multirow{4}{*}{$310^{*}$} & Sand & 0 & 2.11 & 0 \\
\hline & & & & & \multirow{3}{*}{ Silt } & 0 & 0.33 & 2.19 \\
\hline & & & & & & 10 & 1.10 & 1.1 \\
\hline & & & & & & 15 & 0.29 & 2.1 \\
\hline
\end{tabular}

*Value was calculated in laboratory. 


\subsection{Pullout Box B Test Results and Discussion}

Pullout test results for box B are reported an discussed in this section. Two tests were run using this box. The interface consisted of material A and sand. Not enough results have been generated in order to make any conclusions. The stress-strain relationship is presented in Figure 4.112.

\section{PULLOUT STRESS-STRAIN RELATIONSHIP Material A-Sand Interface, $S_{n}=34.5 \mathrm{kPa}$}

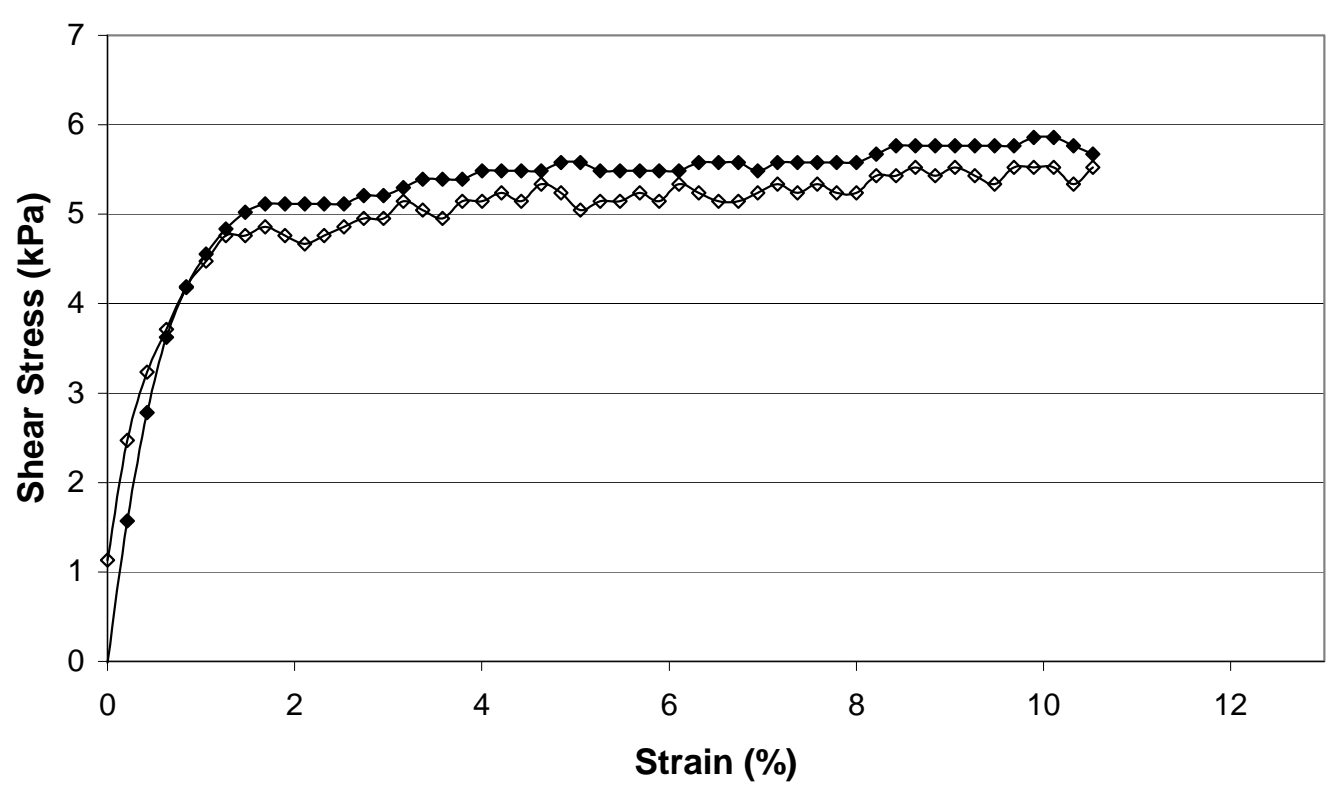

Figure 4.112: Pullout test results for material A-sand interface at $34.5 \mathrm{kPa}$. 


\subsection{Effects of Soil Properties on Pullout Test Results}

Figures 4.113, 4.114 and 4.115 show the test results for all sand and silt -material A interfaces at $0 \%$ water content with different normal stresses. These results show consistently higher shear stress values at failure for material A-sand interface than material A-silt interface. The angle of friction is higher for material A-sand interface than material A-silt interface but yields a lower effective cohesion, see Table 4.2.

\section{PULLOUT TEST RESULTS}

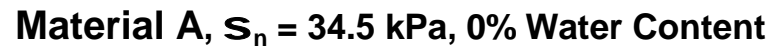

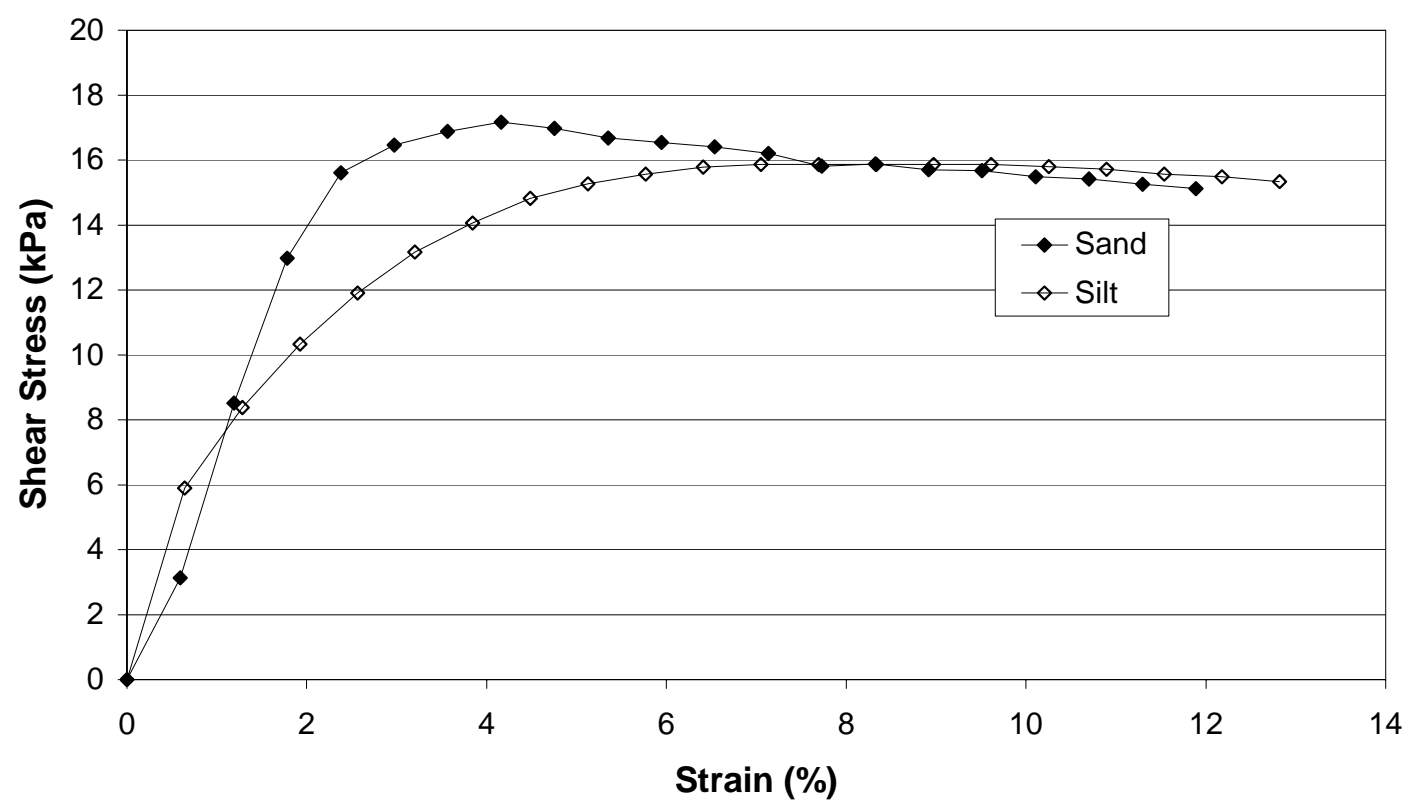

Figure 4.113: Pullout test results for material A-sand and silt interface at $S_{\mathrm{n}}=34.5 \mathrm{kPa}$ and $0 \%$ water content. 
PULLOUT TEST RESULTS

Material $A, S_{n}=69 \mathrm{kPa}, 0 \%$ Water Content

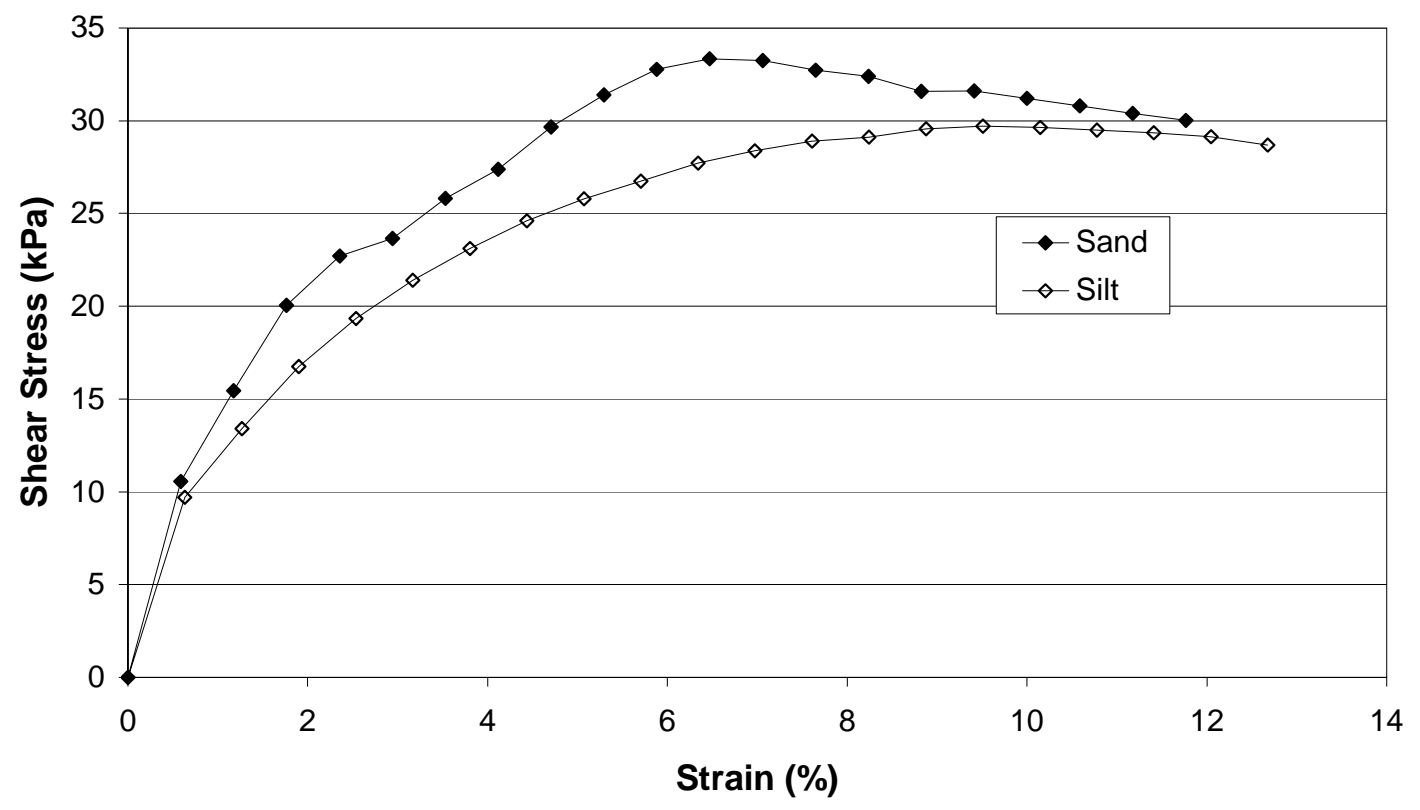

Figure 4.114: Pullout test results for material A-sand and silt interface at $S_{n}=69 \mathrm{kPa}$ and $0 \%$ water content. 
PULLOUT TEST RESULTS

Material A, $S_{n}=103.4 \mathrm{kPa}, 0 \%$ Water Content

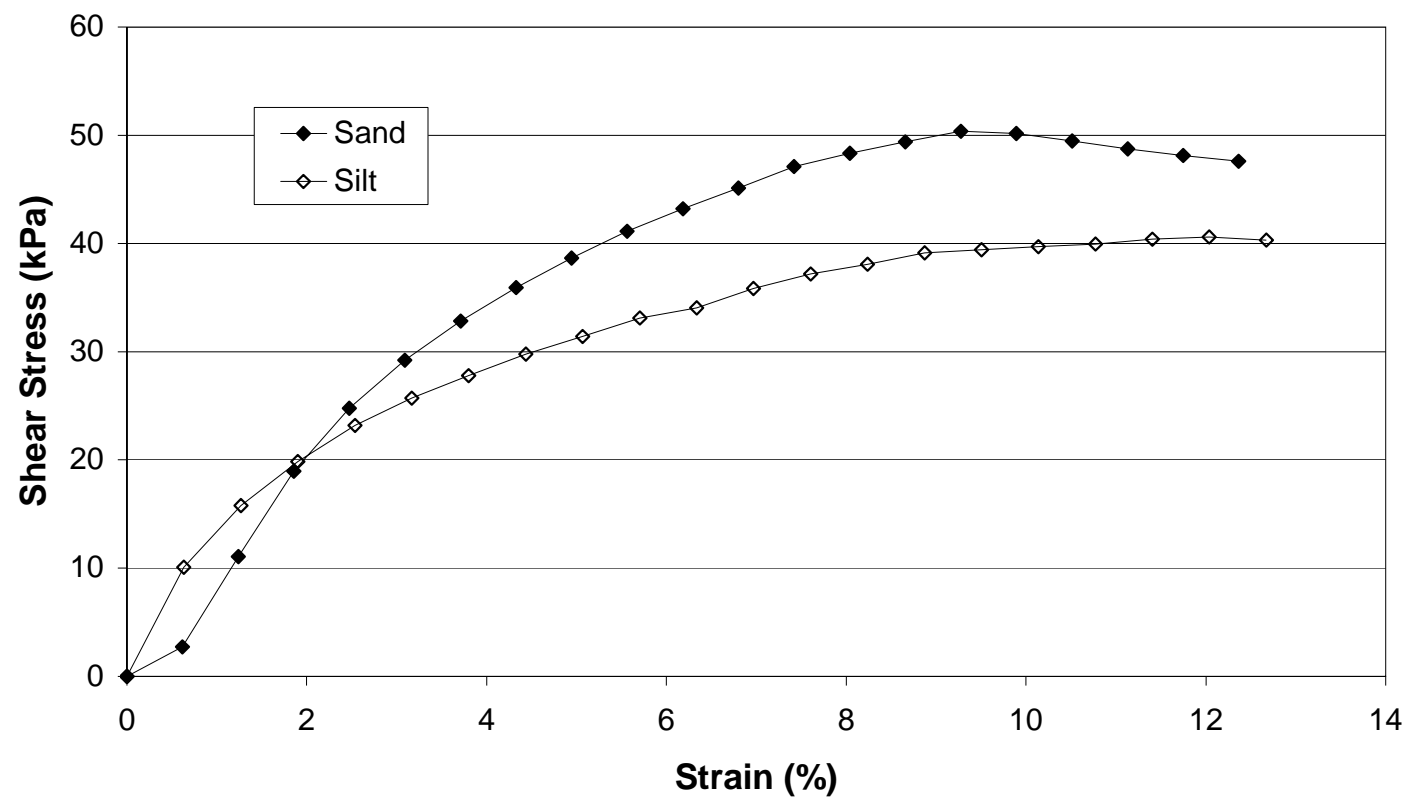

Figure 4.115: Pullout test results for material A-sand and silt interface at $S_{n}=103.4 \mathrm{kPa}$ and $0 \%$ water content. 
Figures 4.116, 4.117 and 4.118 show pullout test results for material C-sand and silt interfaces at $0 \%$ water content and different normal pressures. At normal stresses of $34.5 \mathrm{kPa}$ (5 psi) and $103.4 \mathrm{kPa}$ (15 psi) the material C-silt interface yields slightly higher shear stress values at failure. However, at a normal stress of $69 \mathrm{kPa}$ (10 psi) the material C-sand yields a higher shear stress failure value.

PULLOUT TEST RESULTS

Material $\mathrm{C}, \mathrm{S}_{\mathrm{n}}=34.5 \mathrm{kPa}, 0 \%$ Water Content

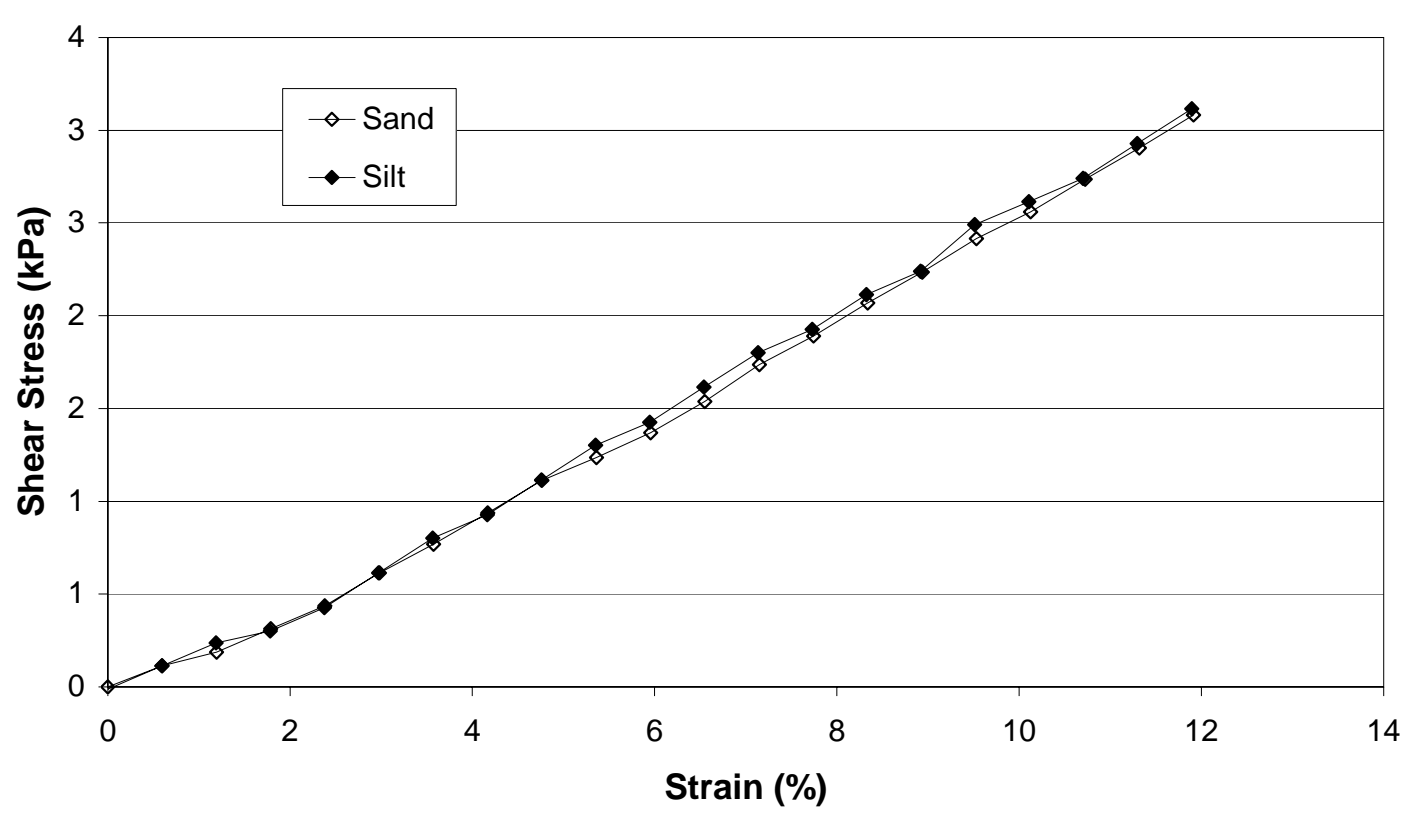

Figure 4.116: Pullout test results for material $\mathrm{C}$-sand and silt interface at $\mathrm{S}_{\mathrm{n}}=34.5 \mathrm{kPa}$ and $0 \%$ water content. 
PULLOUT TEST RESULTS

Material C, $S_{n}=69 \mathrm{kPa}, 0 \%$ Water Content

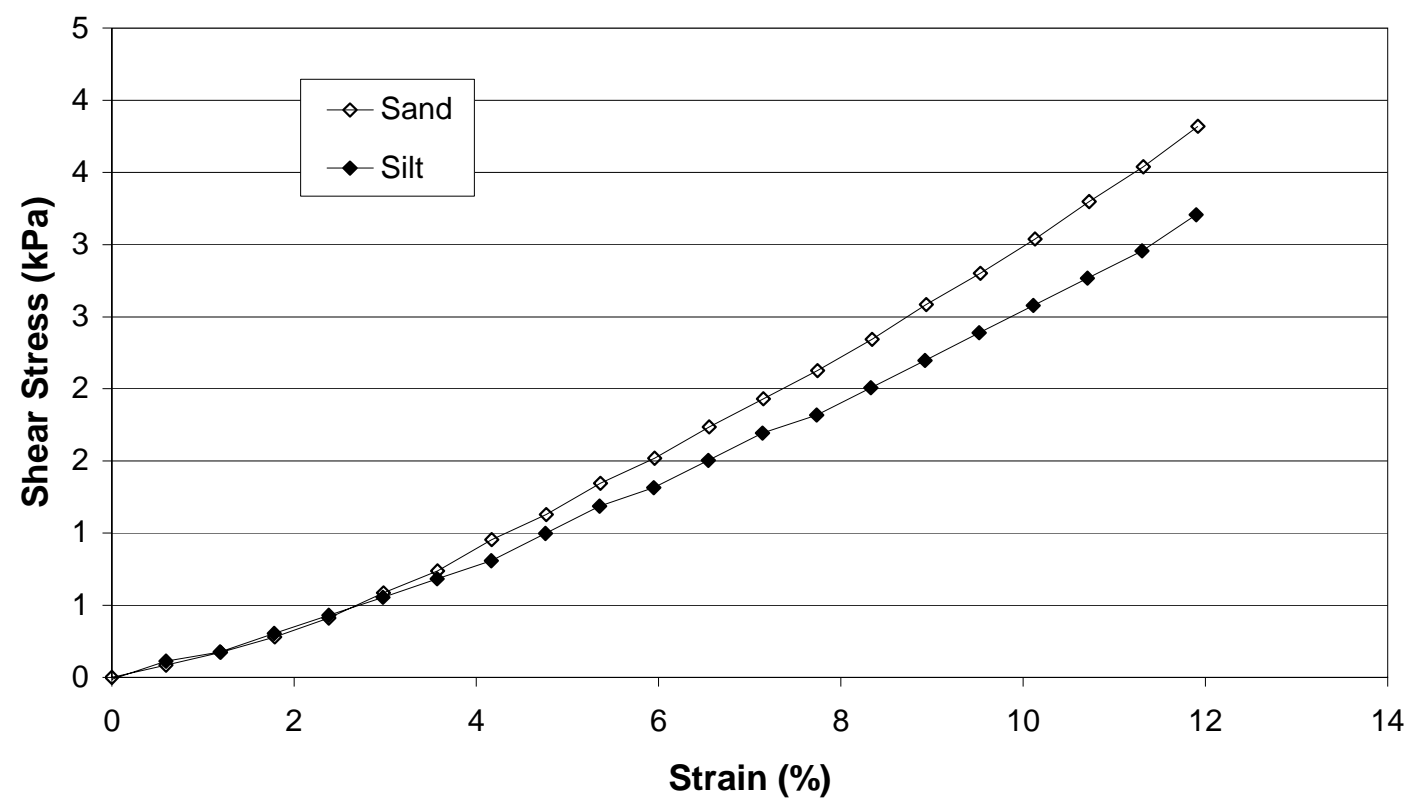

Figure 4.117: Pullout test results for material $\mathrm{C}$-sand and silt interface at $S_{\mathrm{n}}=69 \mathrm{kPa}$ and $0 \%$ water content. 
PULLOUT TEST RESULTS

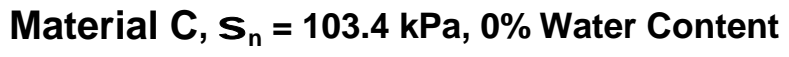

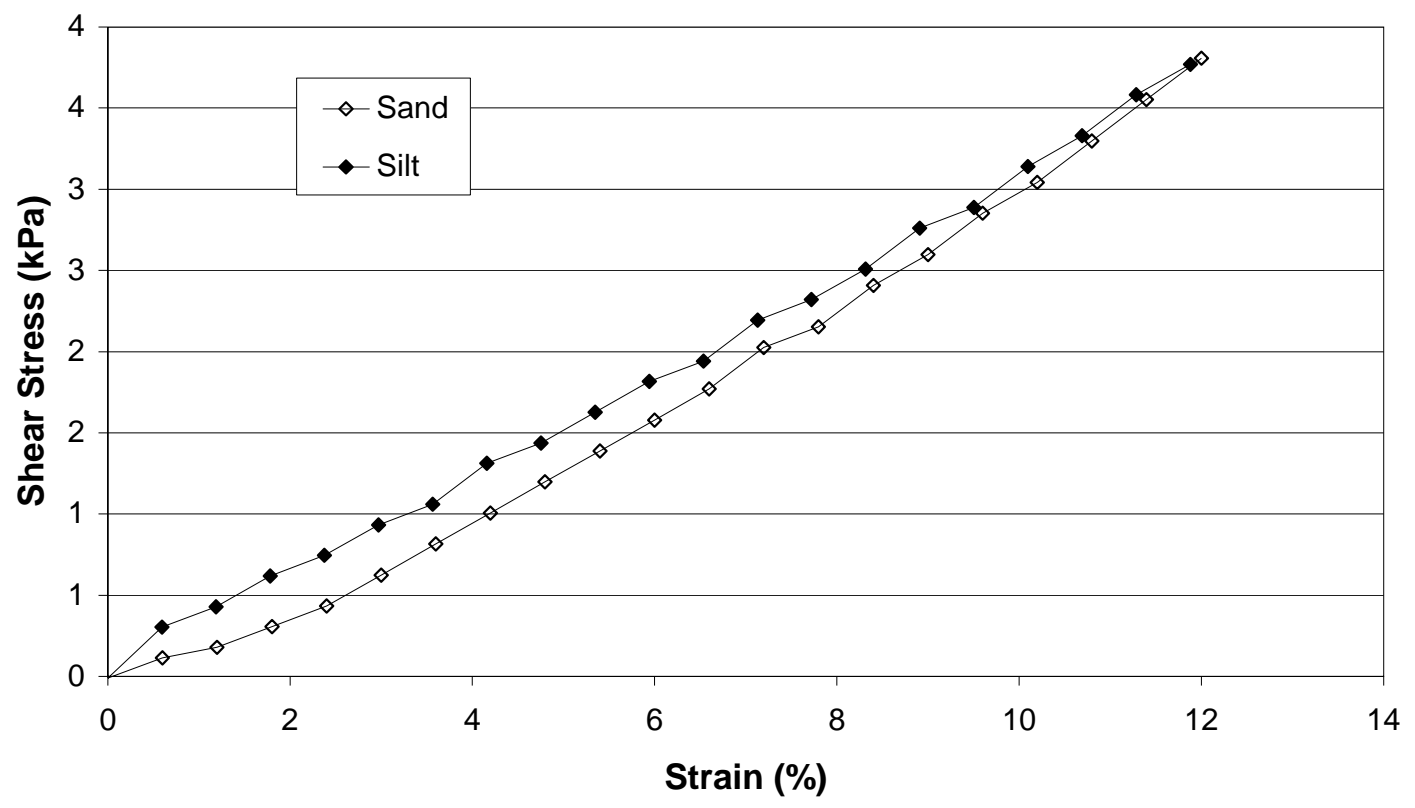

Figure 4.118: Pullout test results for material C-sand and silt interface at $S_{n}=103.4 \mathrm{kPa}$ and $0 \%$ water content. 
Figures 4.119, 4.120 and 4.121 show pullout test results for material B-silt and clay interfaces at $10 \%$ water content. The shear stress failure values for material B-silt interface seem to increase more rapidly than material B-clay interface as normal stresses increase. However, the shear stress failure values for both interfaces and at all three normal stresses are very similar.

PULLOUT TEST RESULTS

Material $\mathrm{B}, \mathrm{S}_{\mathrm{n}}=\mathbf{3 4 . 5} \mathrm{kPa}, 10 \%$ Water Content

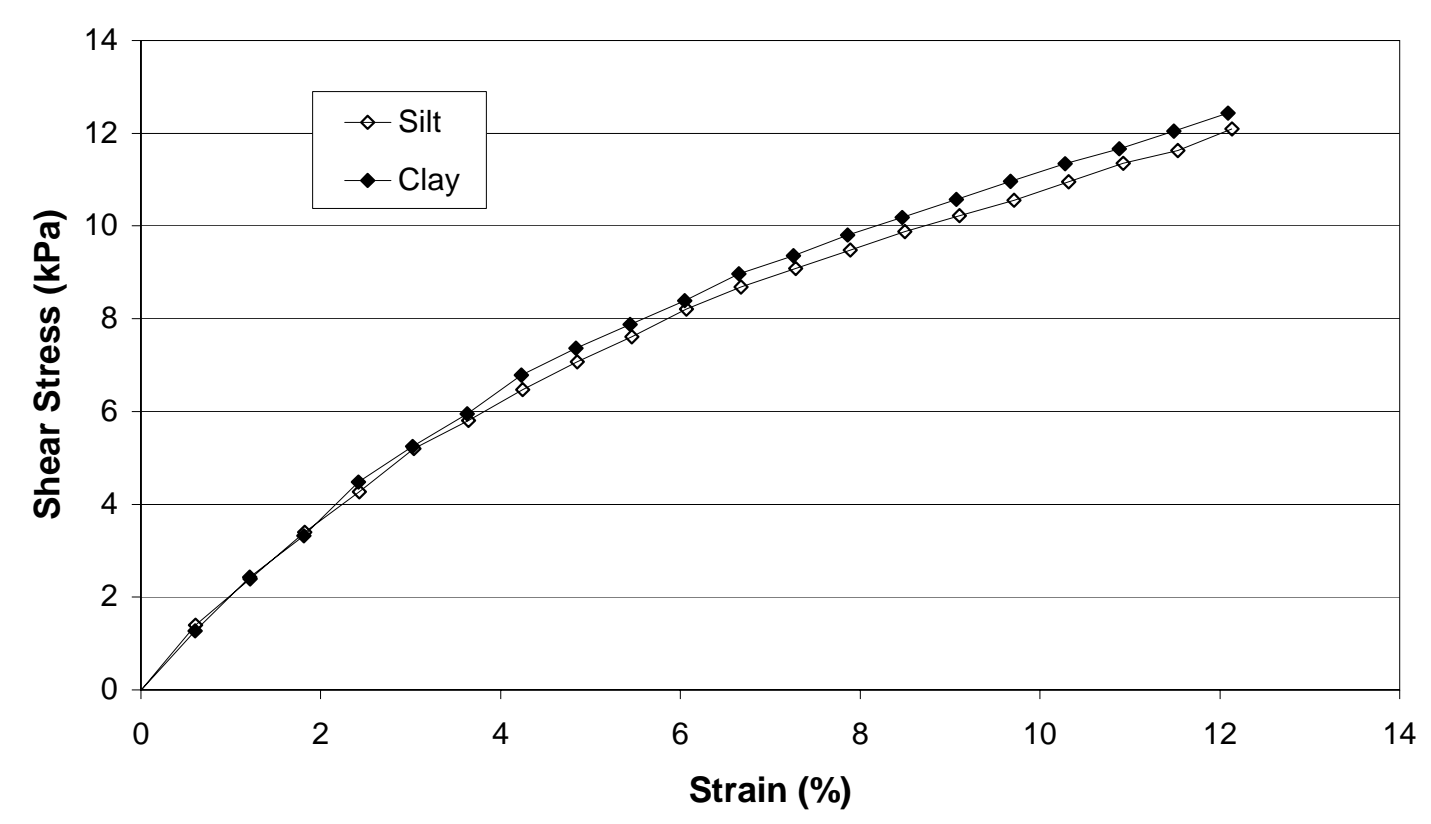

Figure 4.119: Pullout test results for material B-silt and clay interface at $S_{n}=34.5 \mathrm{kPa}$ and $10 \%$ water content. 
PULLOUT TEST RESULTS

Material B, $S_{n}=69 \mathrm{kPa}, 10 \%$ Water Content

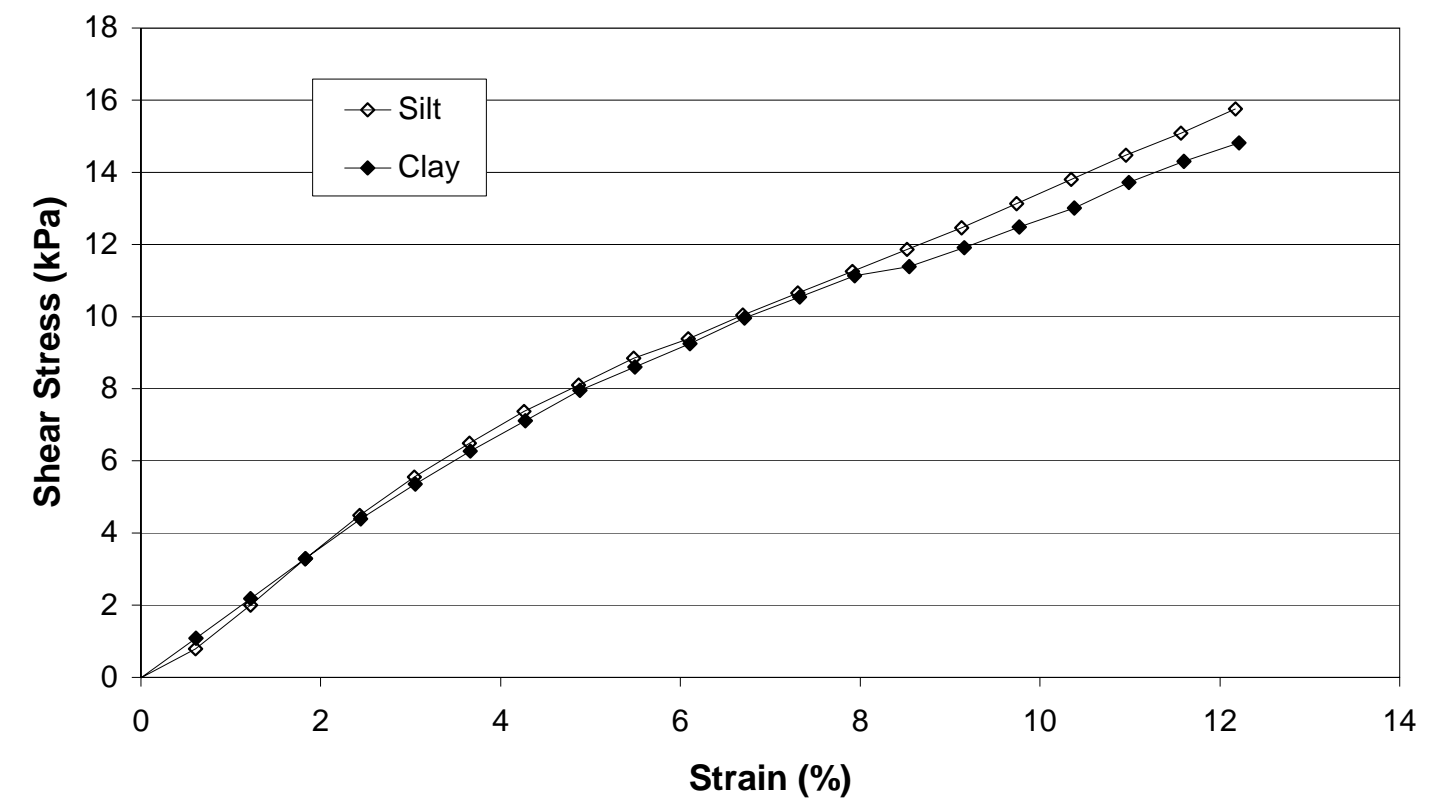

Figure 4.120: Pullout test results for material B-silt and clay interface at $S_{n}=69 \mathrm{kPa}$ and $10 \%$ water content. 
PULLOUT TEST RESULTS

Material $\mathrm{B}, \mathrm{S}_{\mathrm{n}}=103.4 \mathrm{kPa}, 10 \%$ Water Content

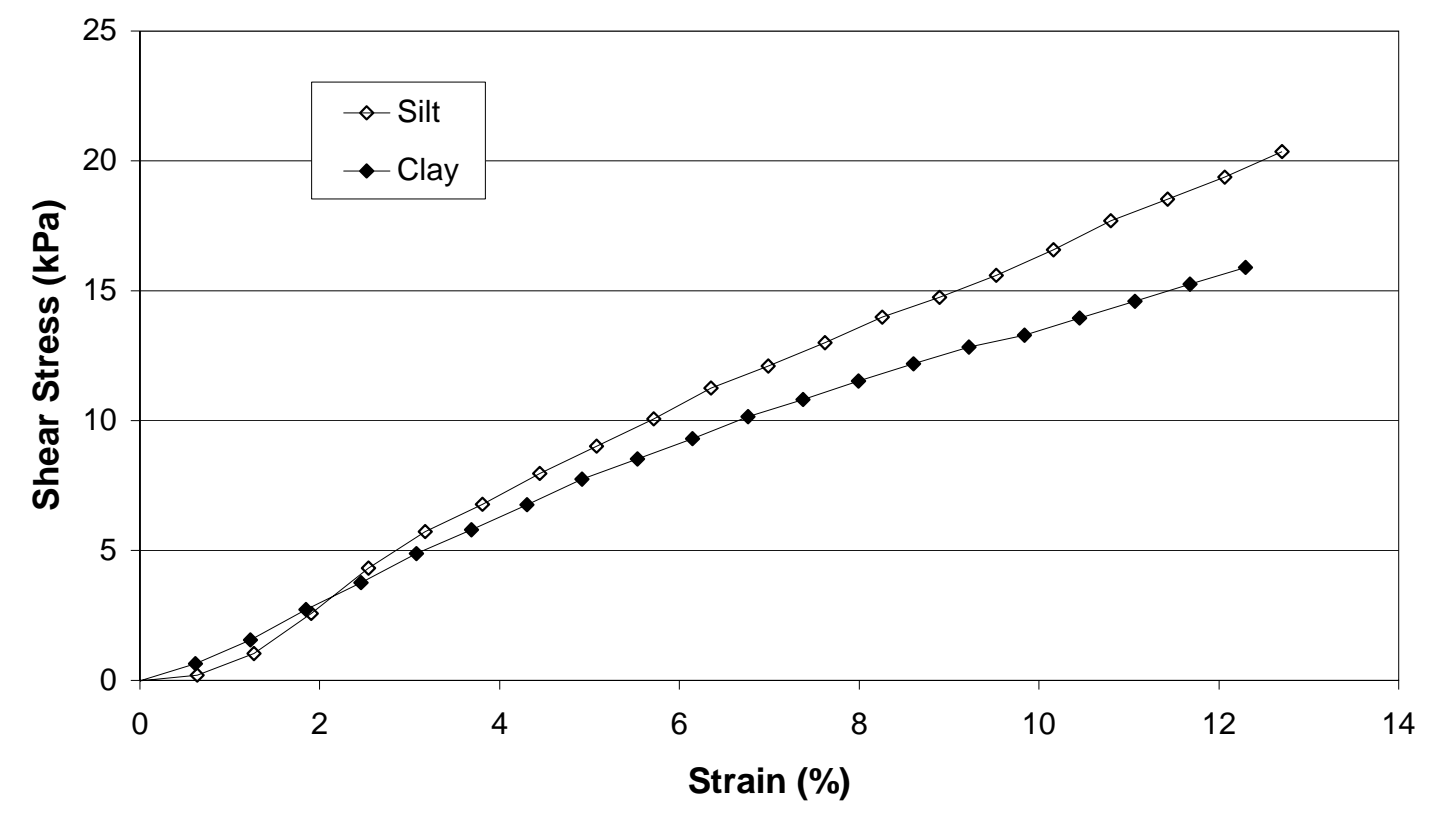

Figure 4.121: Pullout test results for material B-silt and clay interface at $S_{n}=103.4 \mathrm{kPa}$ and $10 \%$ water content. 
Figures 4.122, 4.123 and 4.124 show pullout test results for material B-silt and clay interfaces at $15 \%$ water content. The shear stress failure values for material B-silt interface seem to be greater than material B-clay interface at higher normal stresses. However, the shear stress failure values for both interfaces and at all three normal stresses are very similar. Very similar results were recorded when the same interfaces were tested at a water content of 10\% (see Figures 4.119, 4.120 and 4.121).

PULLOUT TEST RESULTS

Material $\mathrm{B}, \mathrm{S}_{\mathrm{n}}=34.5 \mathrm{kPa}, 15 \%$ Water Content

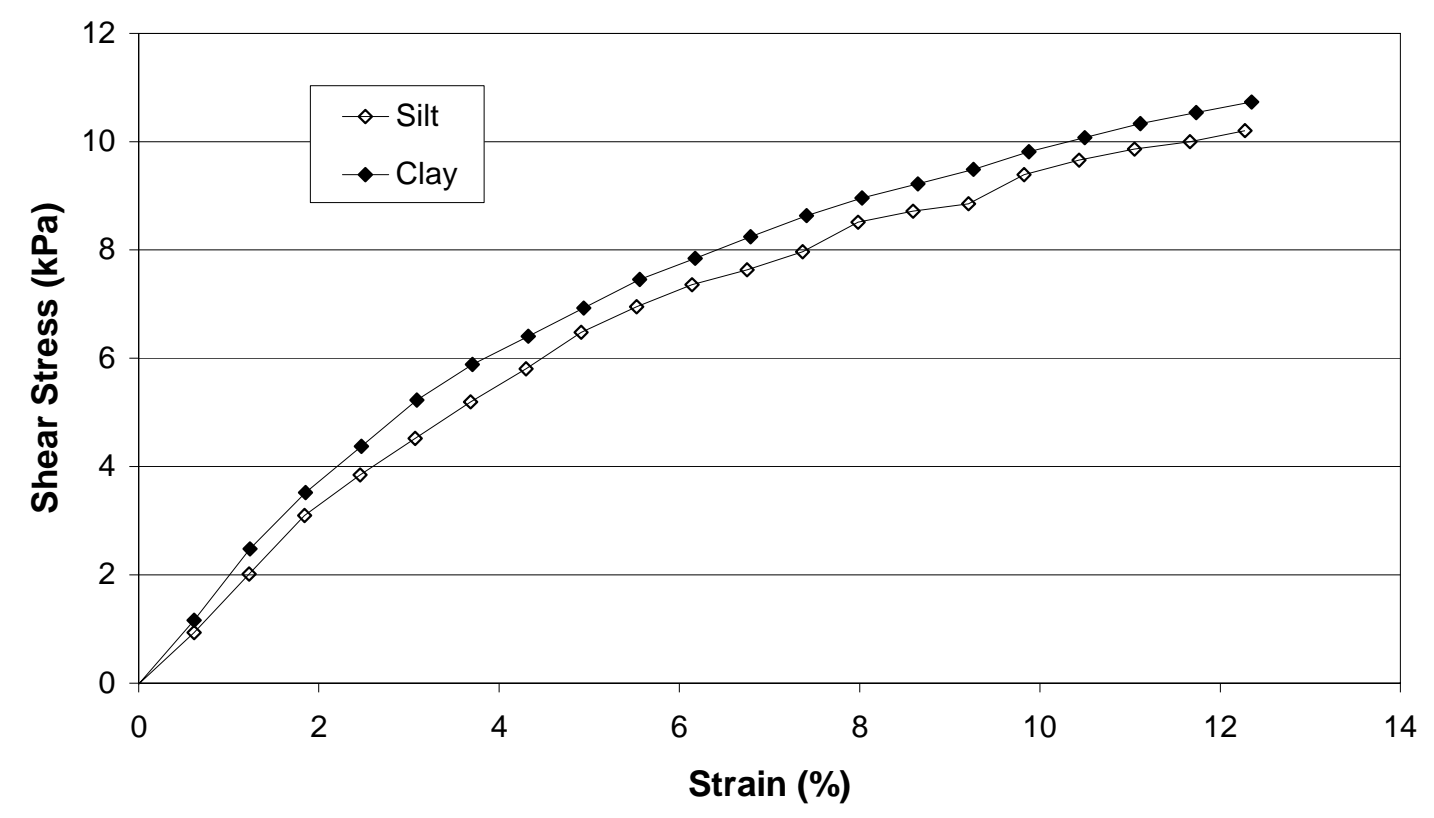

Figure 4.122: Pullout test results for material B-silt and clay interface at $S_{n}=34.5 \mathrm{kPa}$ and $15 \%$ water content. 
PULLOUT TEST RESULTS

Material B, $S_{n}=69 \mathrm{kPa}, 15 \%$ Water Content

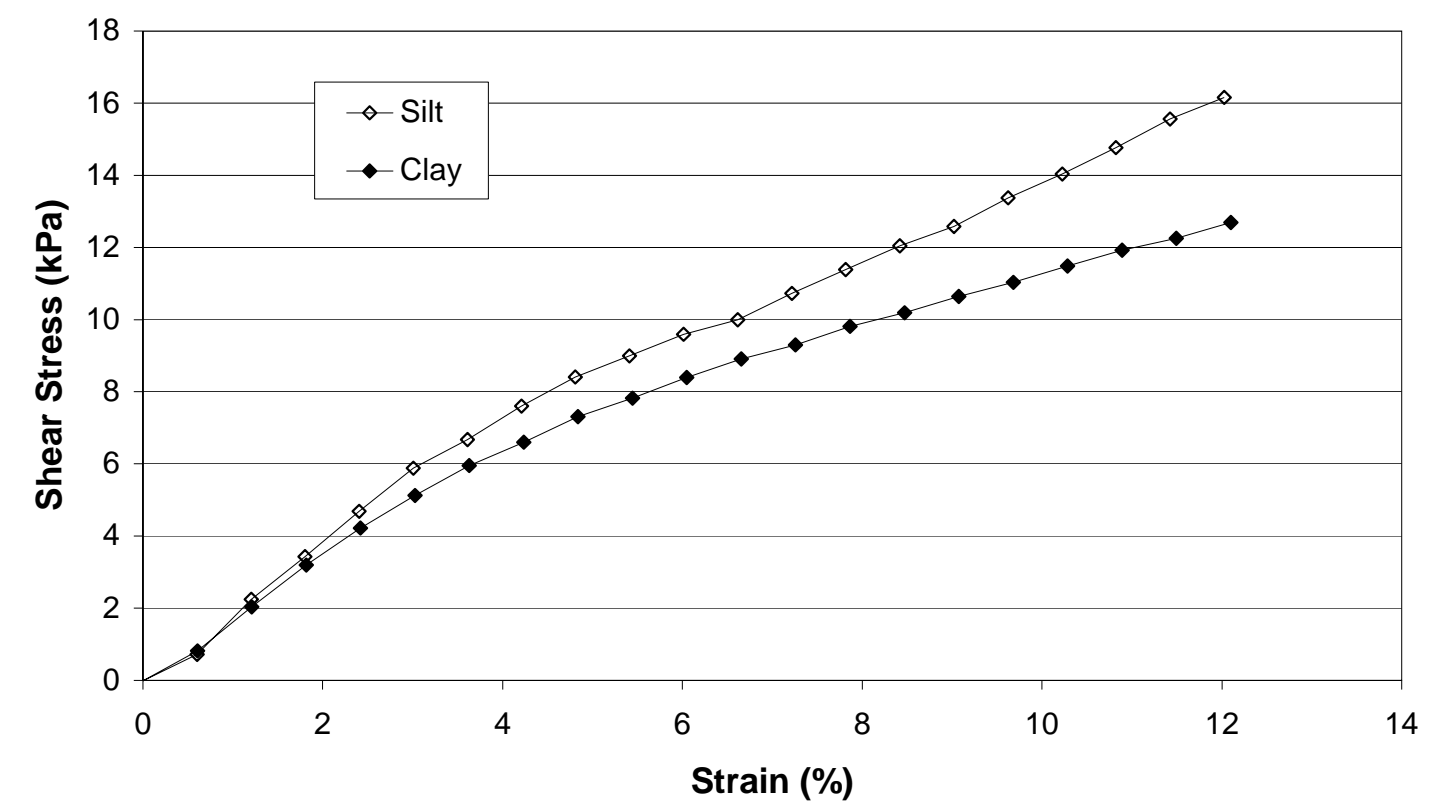

Figure 4.123: Pullout test results for material B-silt and clay interface at $S_{n}=69 \mathrm{kPa}$ and $15 \%$ water content. 
PULLOUT TEST RESULTS

Material $\mathrm{B}, \mathrm{S}_{\mathrm{n}}=103.4 \mathrm{kPa}, 15 \%$ Water Content

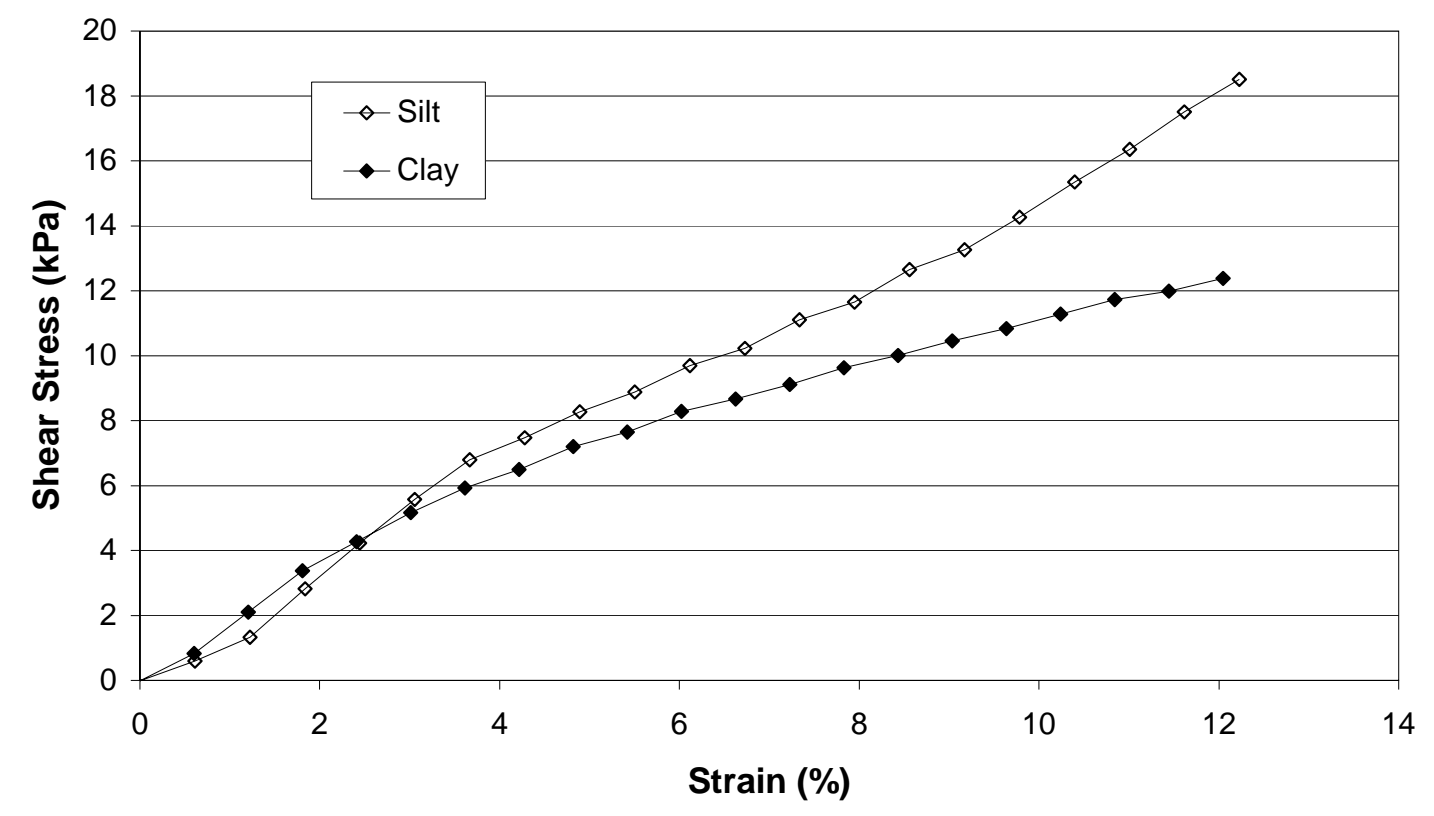

Figure 4.124: Pullout test results for material B-silt and clay interface at $S_{n}=103.4 \mathrm{kPa}$ and $15 \%$ water content. 
Figures 4.125, 4.126 and 4.127 illustrate the pullout test results for material Bsand, silt and clay interfaces at $0 \%$ water content and different normal stresses. For all normal stresses the shear stress failure values decrease as the percent of clay in the soil increases. However, this is more obvious at lower normal stresses.

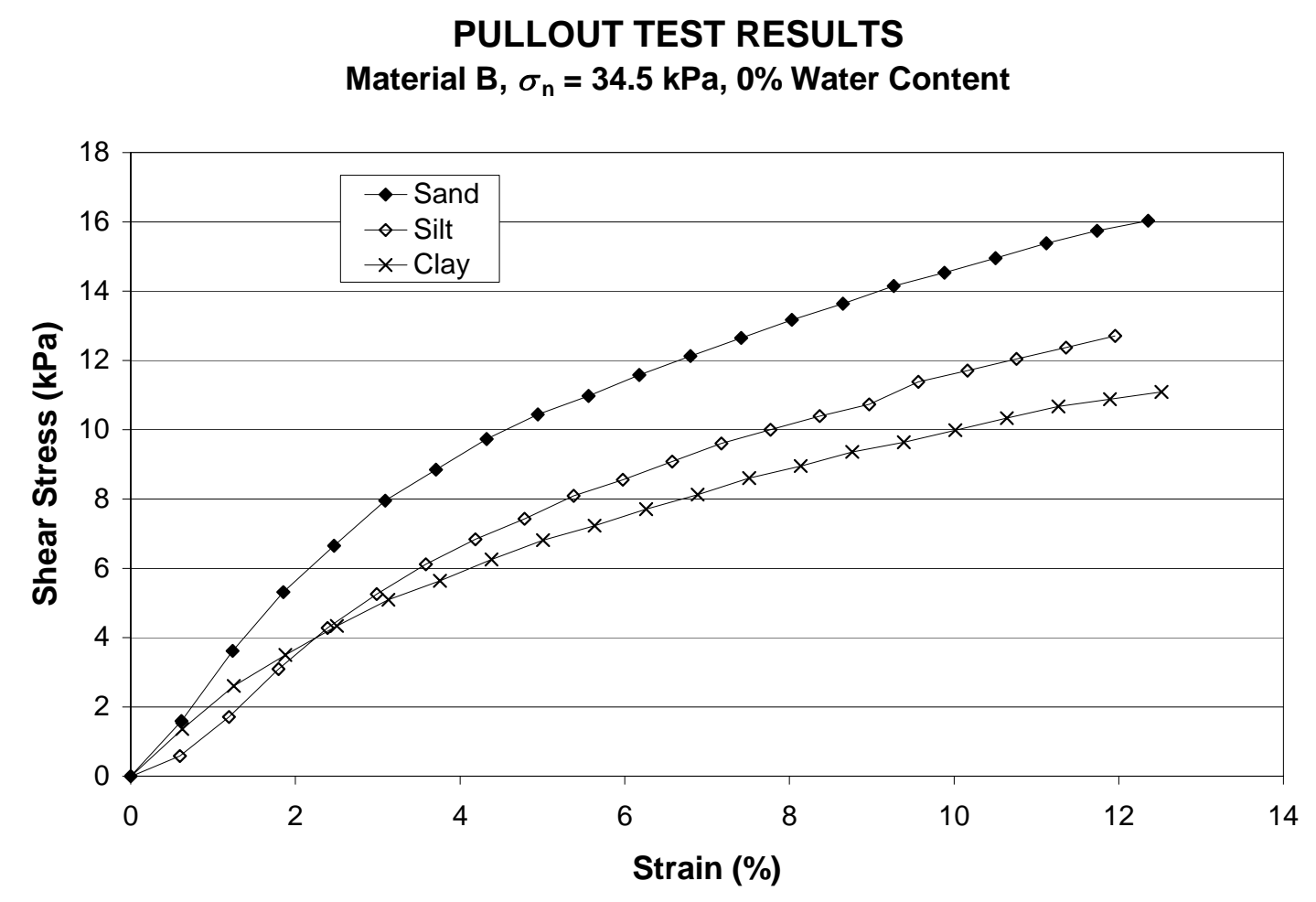

Figure 4.125: Pullout test results for material B-sand, silt and clay interfaces at $0 \%$ water content and $S_{n}=34.5 \mathrm{kPa}$. 
PULLOUT TEST RESULTS

Material B, $\sigma_{n}=69 \mathrm{kPa}, 0 \%$ Water Content

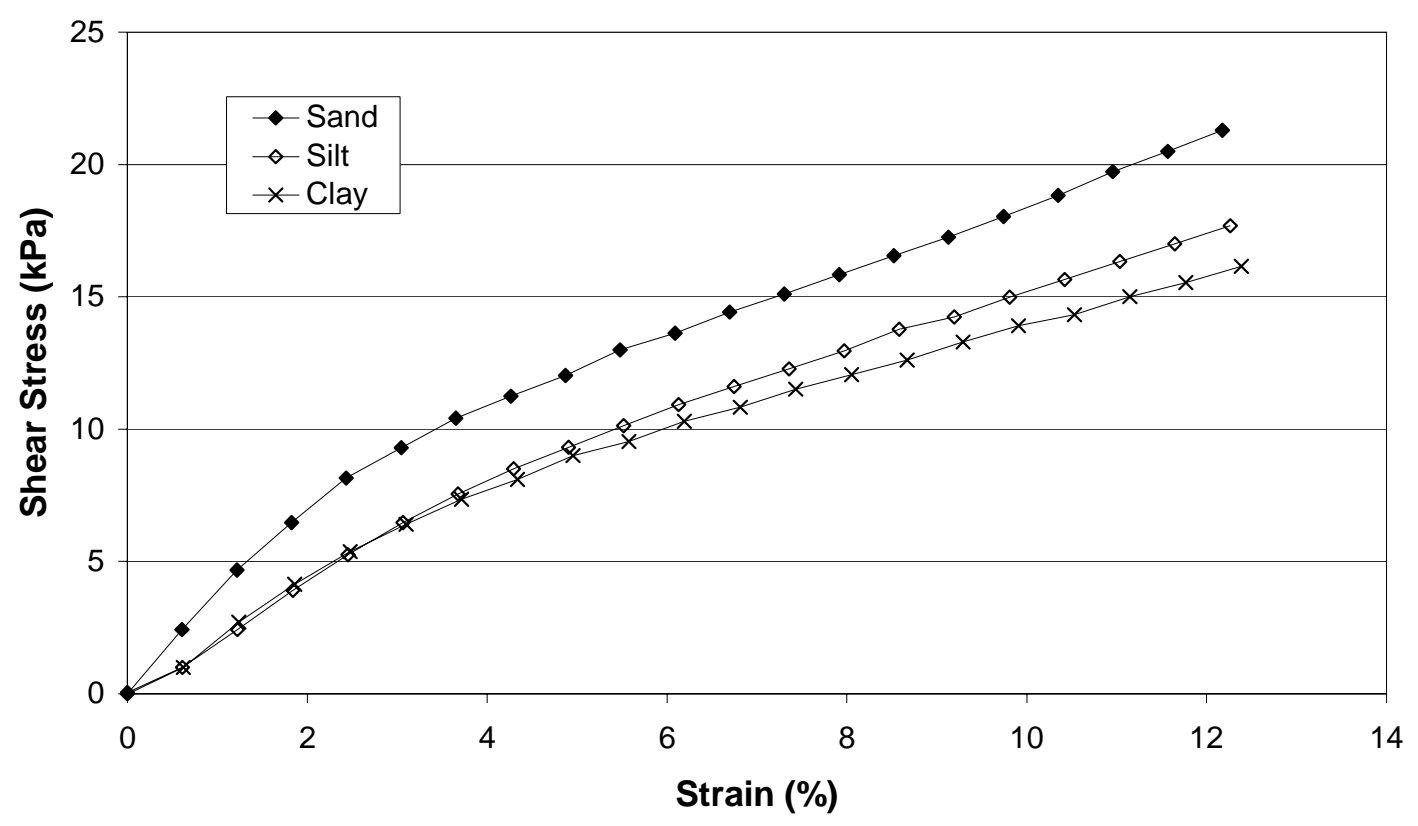

Figure 4.126: Pullout test results for material B-sand, silt, and clay interfaces at $0 \%$ water content and $S_{n}=69 \mathrm{kPa}$. 


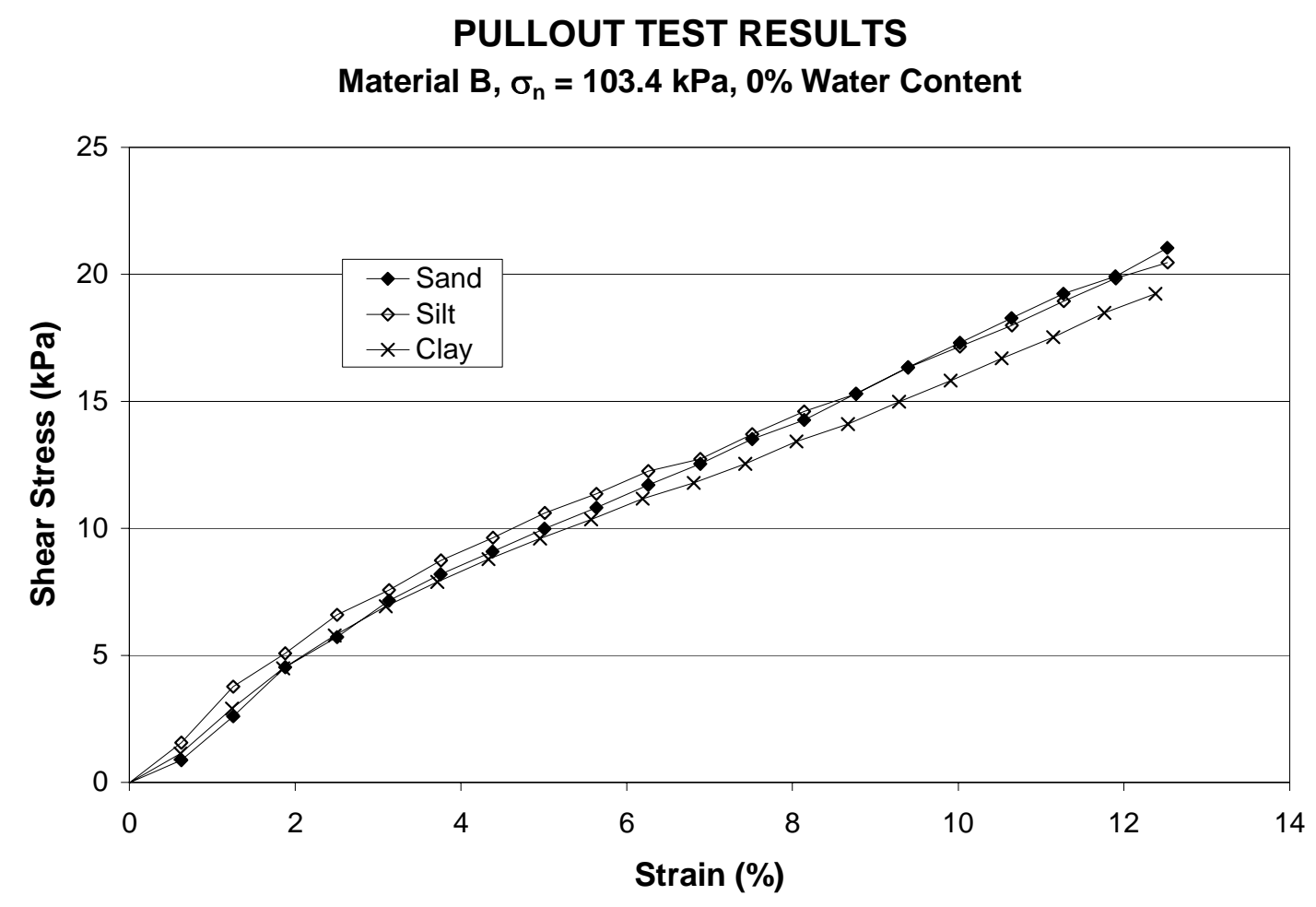

Figure 4.127: Pullout test results for material B-sand, silt, and clay interfaces at $0 \%$ water content and $S_{n}=103.4 \mathrm{kPa}$. 


\subsection{Effects of Geosynthetic Properties on Pullout Test Results}

Figures 4.128, 4.129 and 4.130 show the pullout test results for material A, B and C-sand interfaces at three different normal stresses. These results show that normal stress has no effect on the influence of geosynthetic properties. Tensile strength of the geosynthetic material seems to affect the pullout shear stress failure values directly.

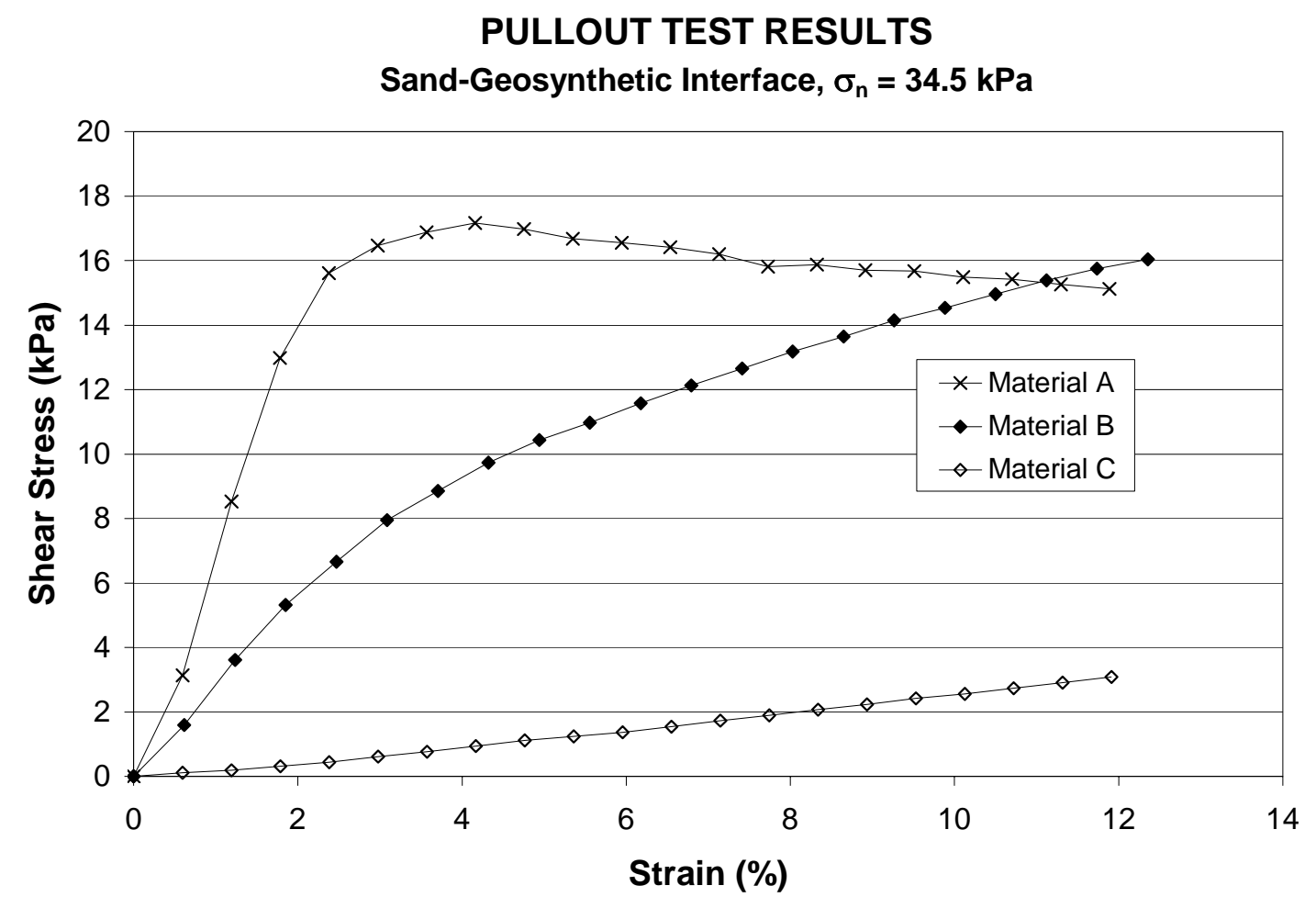

Figure 4.128: Pullout test results for geosynthetic-sand interfaces at $S_{n}=34.5 \mathrm{kPa}$. 


\section{PULLOUT TEST RESULTS}

Sand-Geosynthetic Interface, $\sigma_{\mathrm{n}}=69 \mathrm{kPa}$

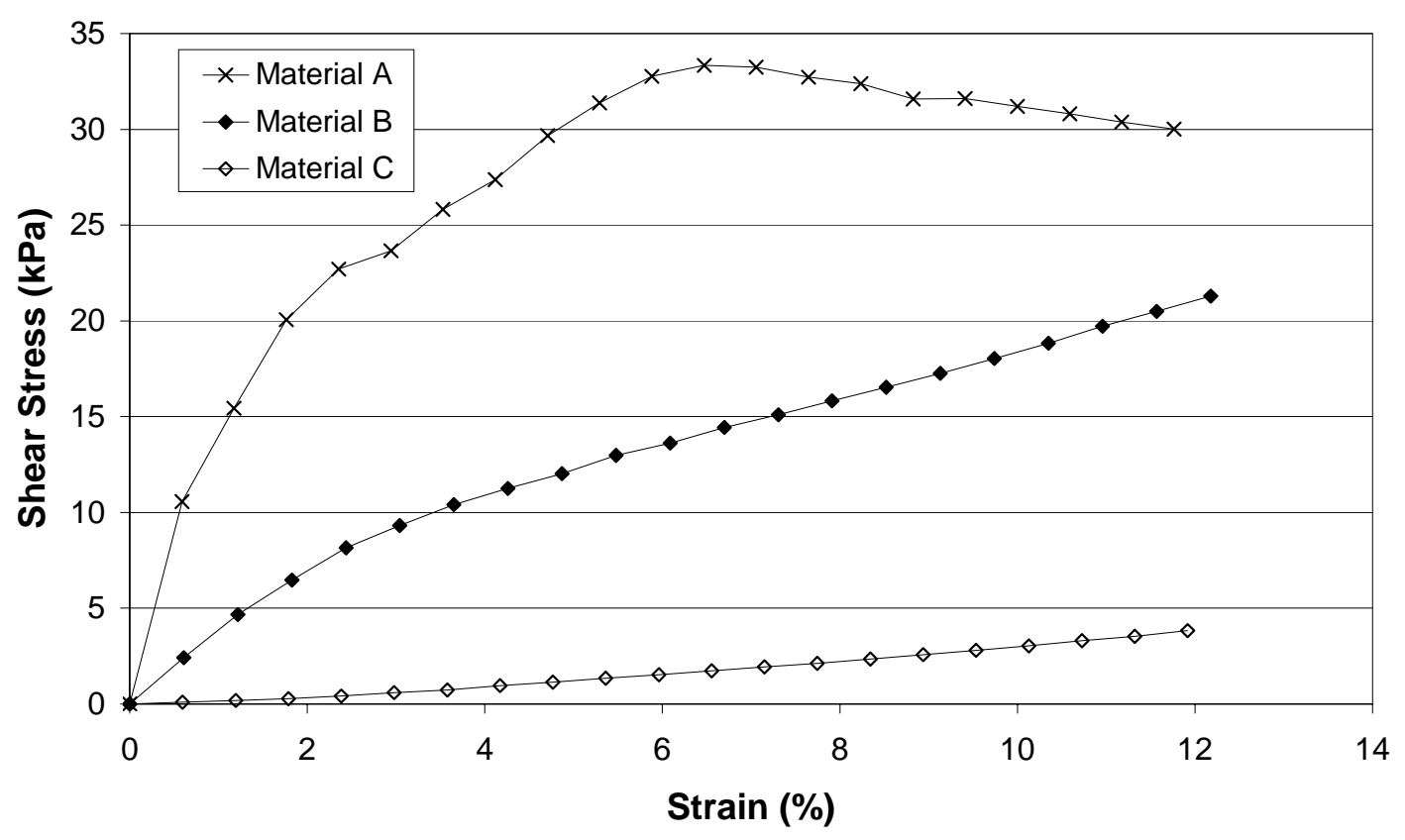

Figure 4.129: Pullout test results for geosynthetic-sand interfaces at $S_{n}=69 \mathrm{kPa}$. 
PULLOUT TEST RESULTS

Sand-Geosynthetic Interface, $\sigma_{n}=103.4 \mathrm{kPa}$

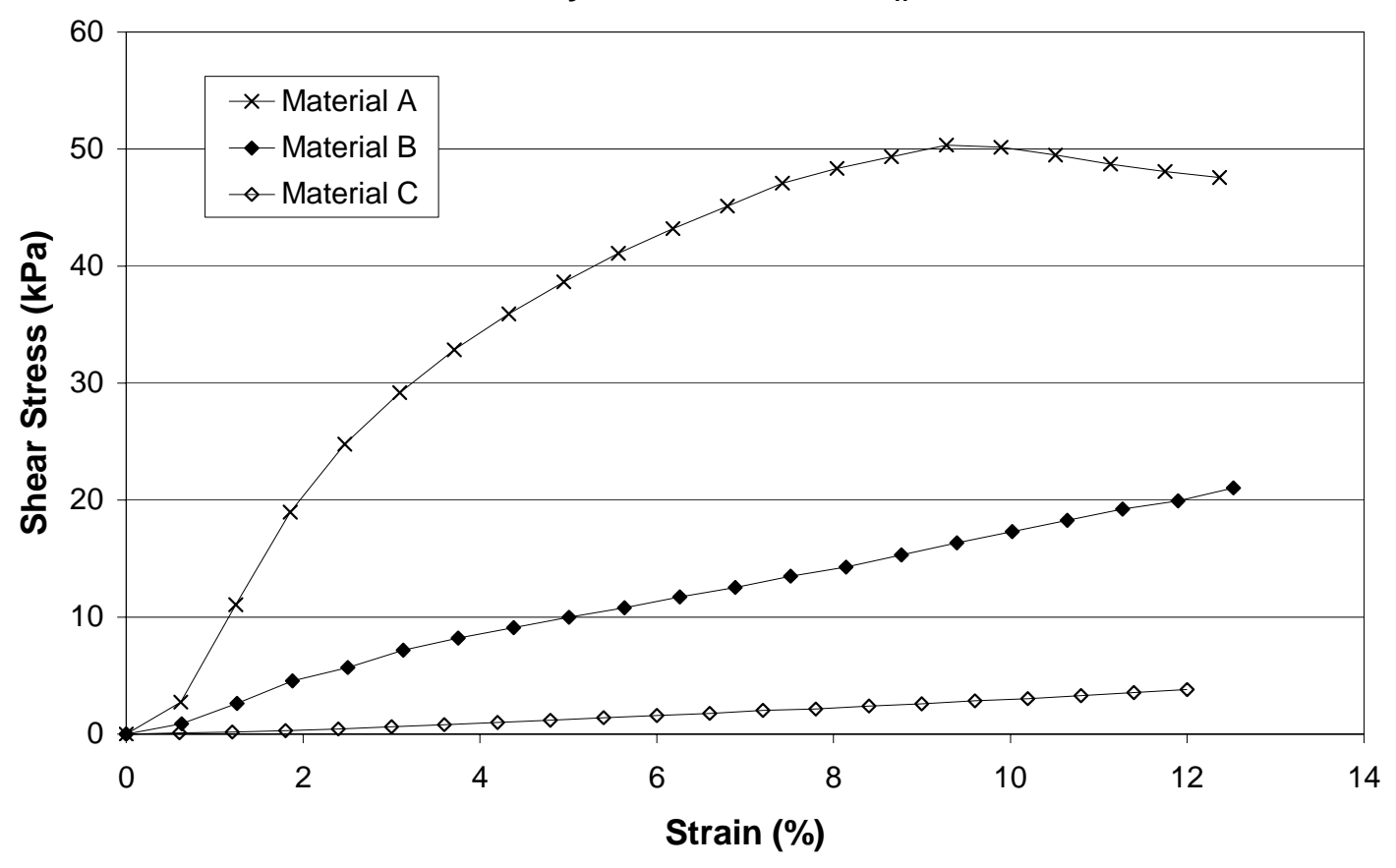

Figure 4.130: Pullout test results for geosynthetic-sand interface at $S_{n}=103.4 \mathrm{kPa}$. 
Figures 4.131 through 4.139 show pullout test results for geosynthetic-silt interfaces. Three water contents were used, $0 \%, 10 \%$ and $15 \%$, to evaluate the effect of moisture on the interface properties. Water content seems to have no effect on geosynthetic property influences.

PULLOUT TEST RESULTS

Silt-Geosynthetic Interface, $\sigma_{\mathrm{n}}=34 . .5 \mathrm{kPa}, 0 \%$ water content

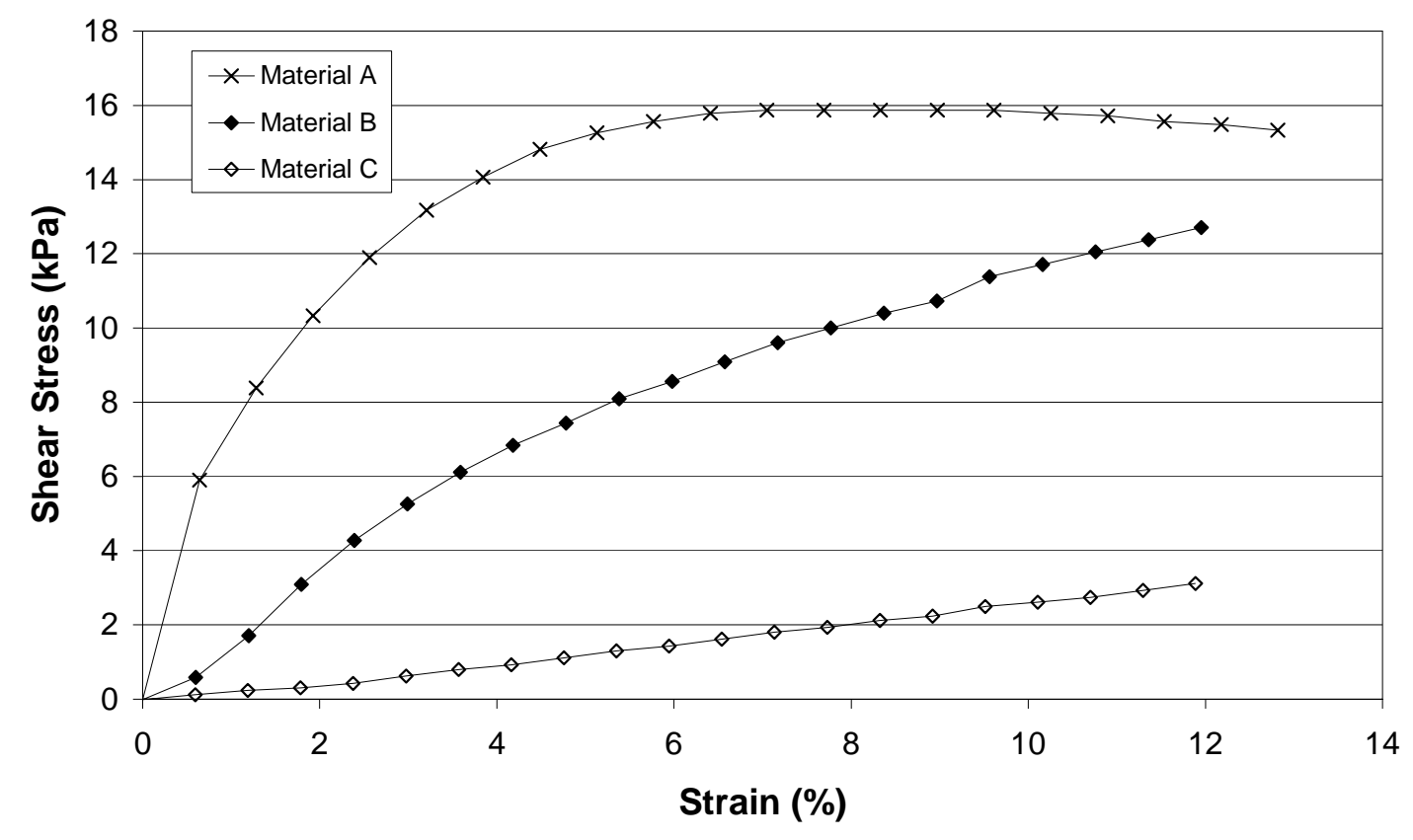

Figure 4.131: Pullout results for materials A, B, and C, $S_{n}=34.5 \mathrm{kPa}$, silt $0 \%$ water content. 
PULLOUT TEST RESULTS

Silt-Geosynthetic Interface, $\sigma_{\mathrm{n}}=34.5 \mathrm{kPa}, 10 \%$ water content

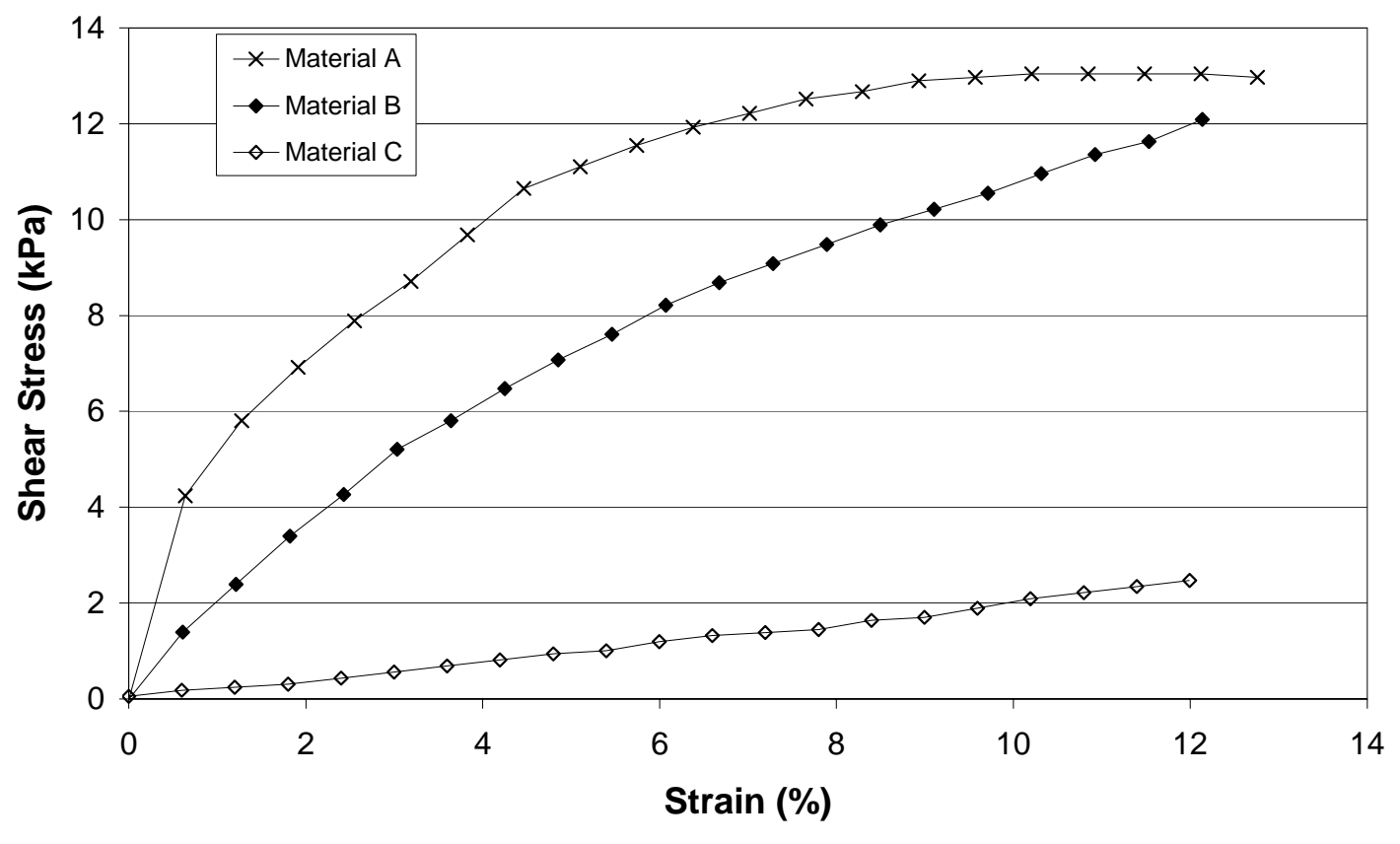

Figure 4.132: Pullout test results for materials A, B, and C-silt interfaces at $S_{n}=34.5 \mathrm{kPa}$ and silt $10 \%$ water content. 


\section{PULLOUT TEST RESULTS}

Silt-Geosynthetic Interface, $\sigma_{\mathrm{n}}=34.5 \mathrm{kPa}, 15 \%$ water content

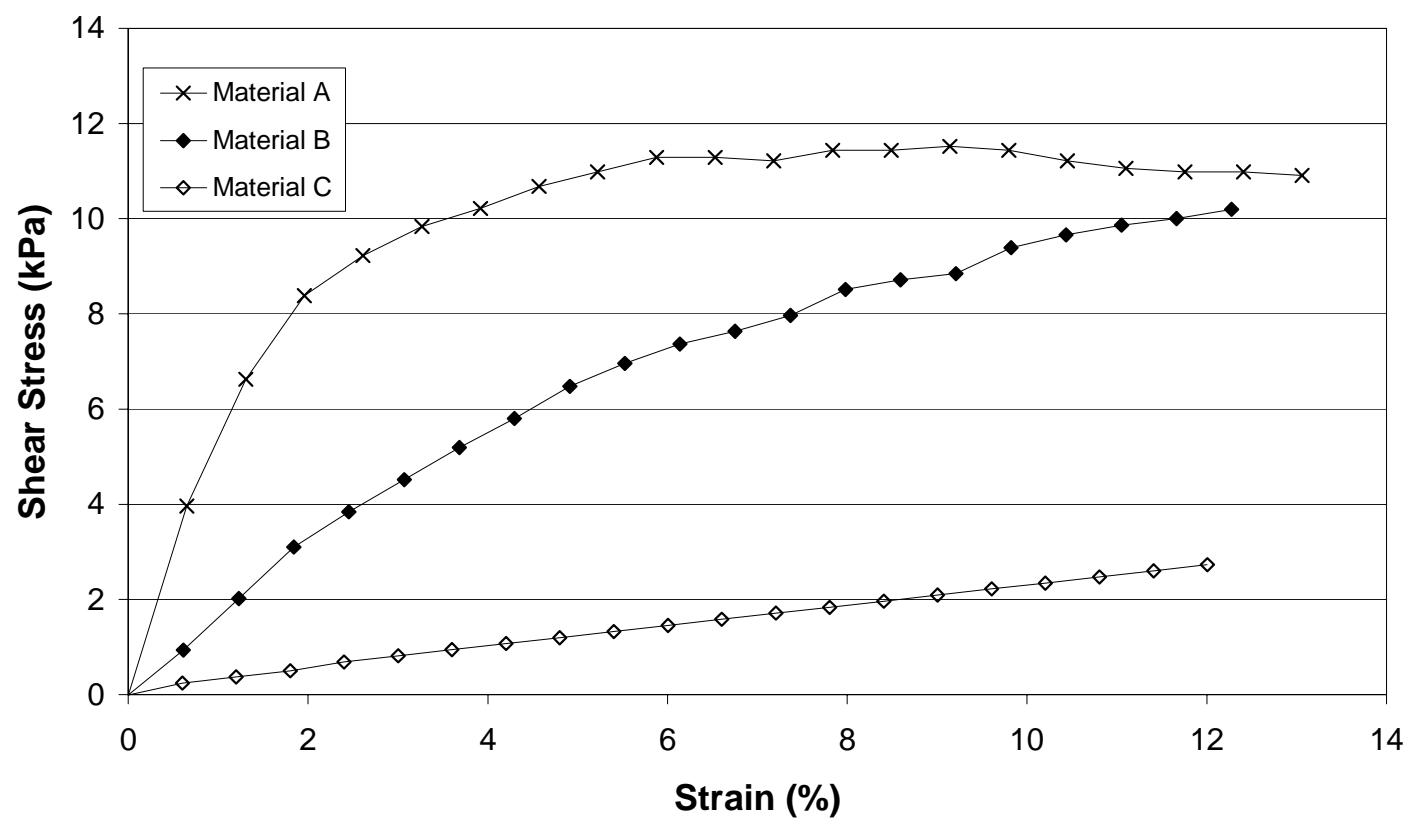

Figure 4.133: Pullout test results for materials A, B, and C-silt interfaces at $S_{n}=\mathbf{3 4 . 5} \mathrm{kPa}$ and silt $15 \%$ water content. 


\section{PULLOUT TEST RESULTS}

Silt-Geosynthetic Interface, $\sigma_{\mathrm{n}}=69 \mathrm{kPa}, 0 \%$ water content

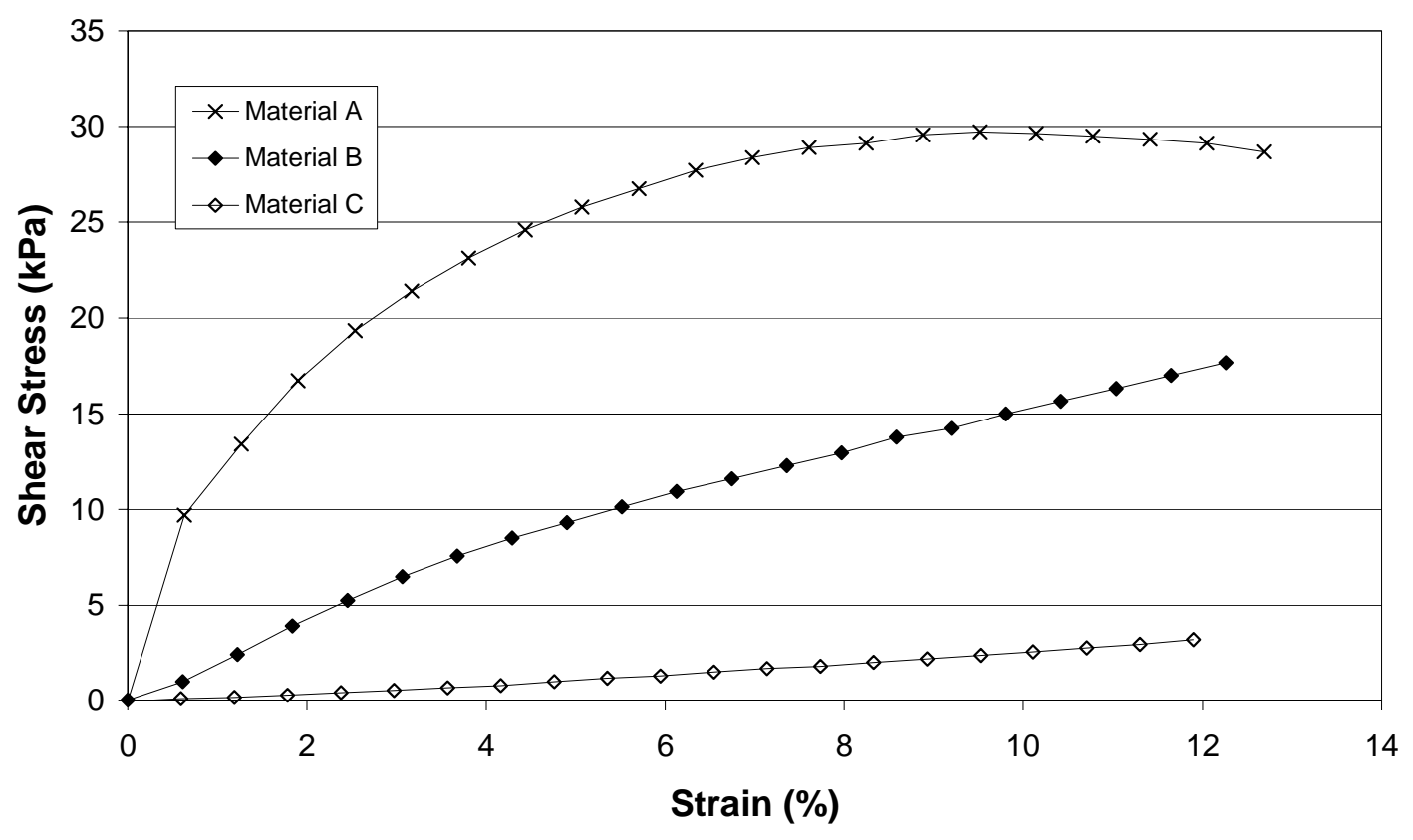

Figure 4.134: Pullout test results for materials $A, B$, and C-silt interfaces at $S_{n}=69 \mathrm{kPa}$ and silt $0 \%$ water content. 


\section{PULLOUT TEST RESULTS}

Silt-Geosynthetic Interface, $\sigma_{\mathrm{n}}=69 \mathrm{kPa}, 10 \%$ water content

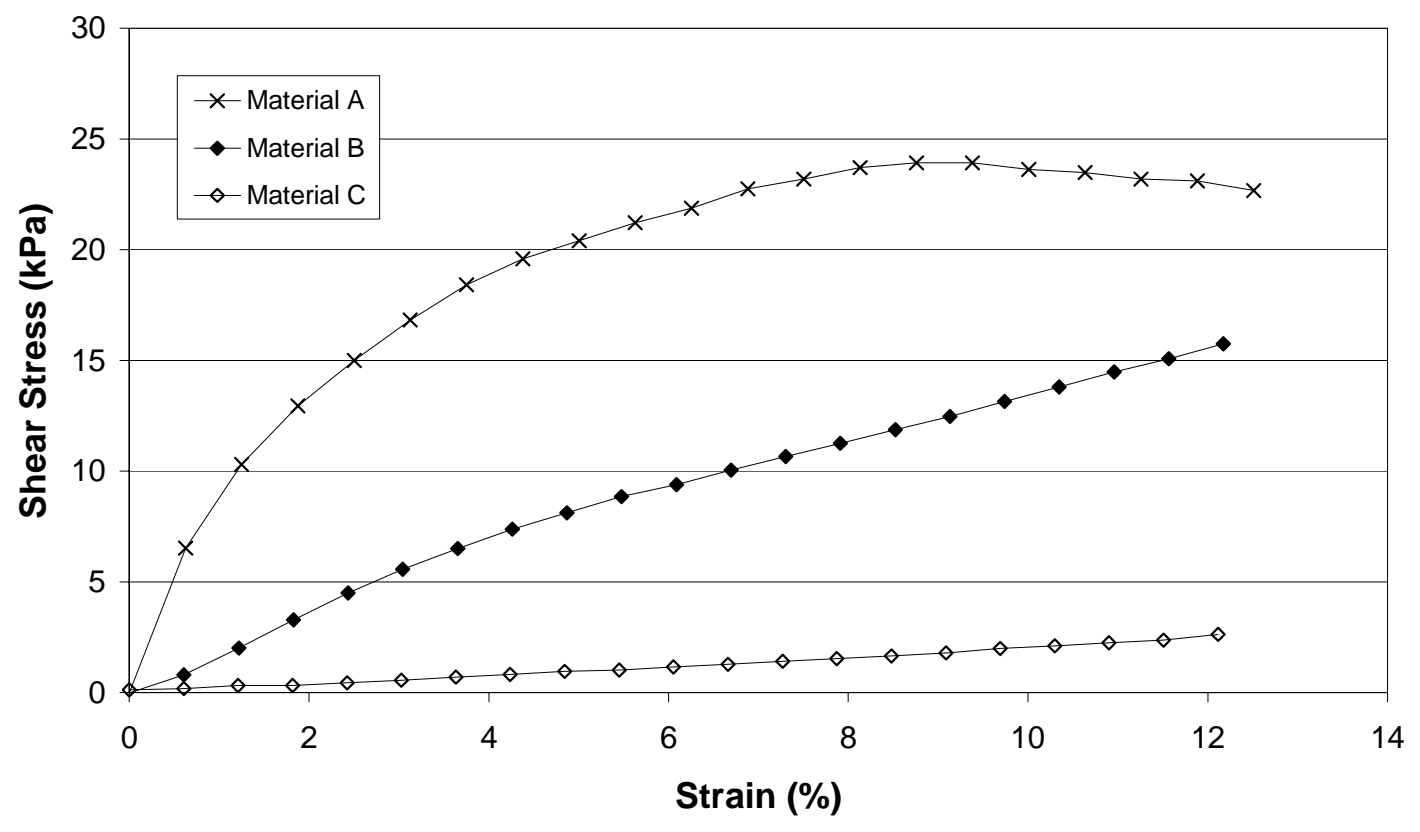

Figure 4.135: Pullout test results for materials A, B, and C-silt interfaces at $S_{n}=69 \mathrm{kPa}$ and silt $10 \%$ water content. 


\section{PULLOUT TEST RESULTS}

Silt-Geosynthetic Interface, $\sigma_{\mathrm{n}}=69 \mathrm{kPa}, 15 \%$ water content

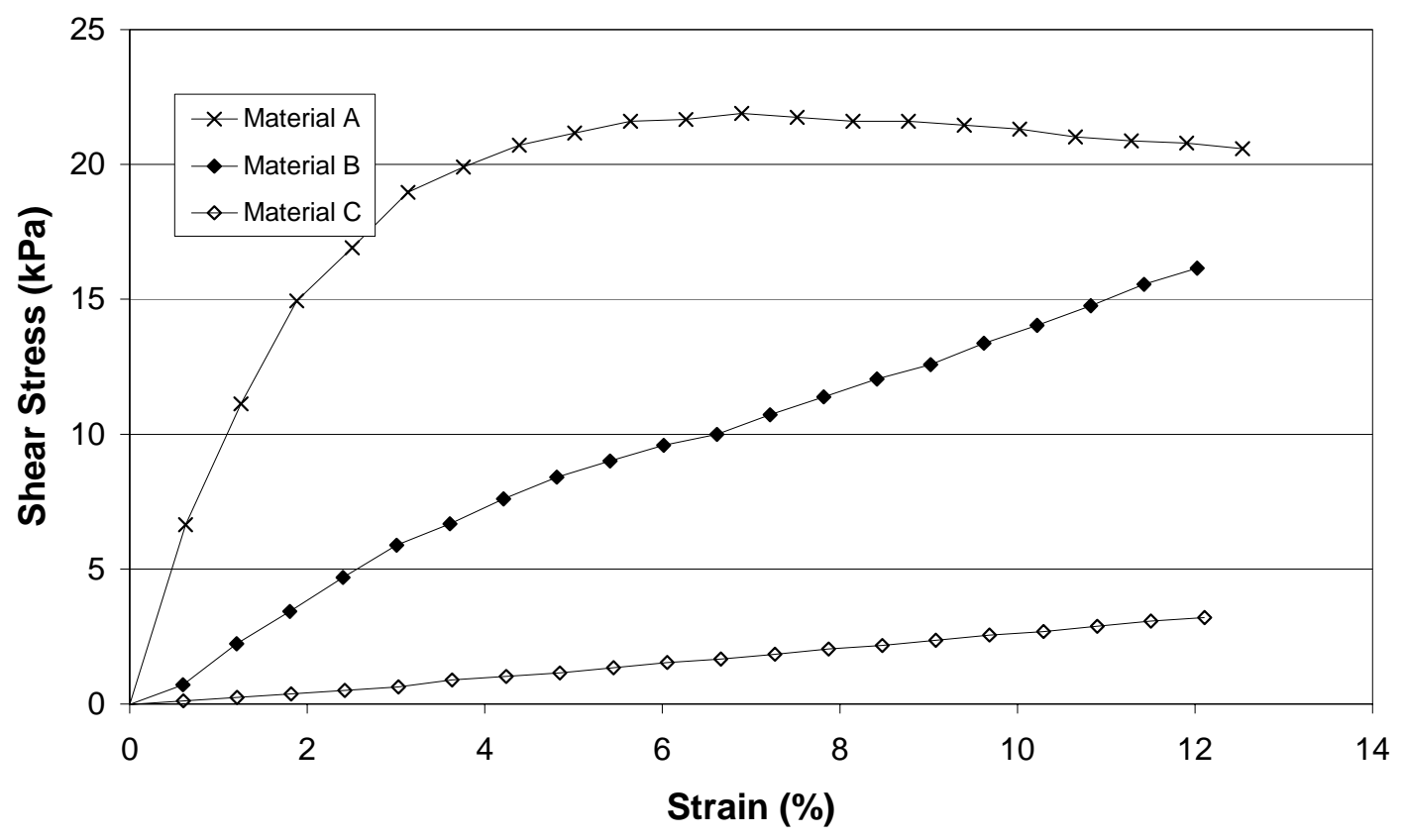

Figure 4.136: Pullout test results for materials A, B, and C-silt interfaces at $S_{n}=69 \mathrm{kPa}$ and silt $15 \%$ water content. 


\section{PULLOUT TEST RESULTS}

Silt-Geosynthetic Interface, $\sigma_{\mathrm{n}}=103.4 \mathrm{kPa}, 0 \%$ water content

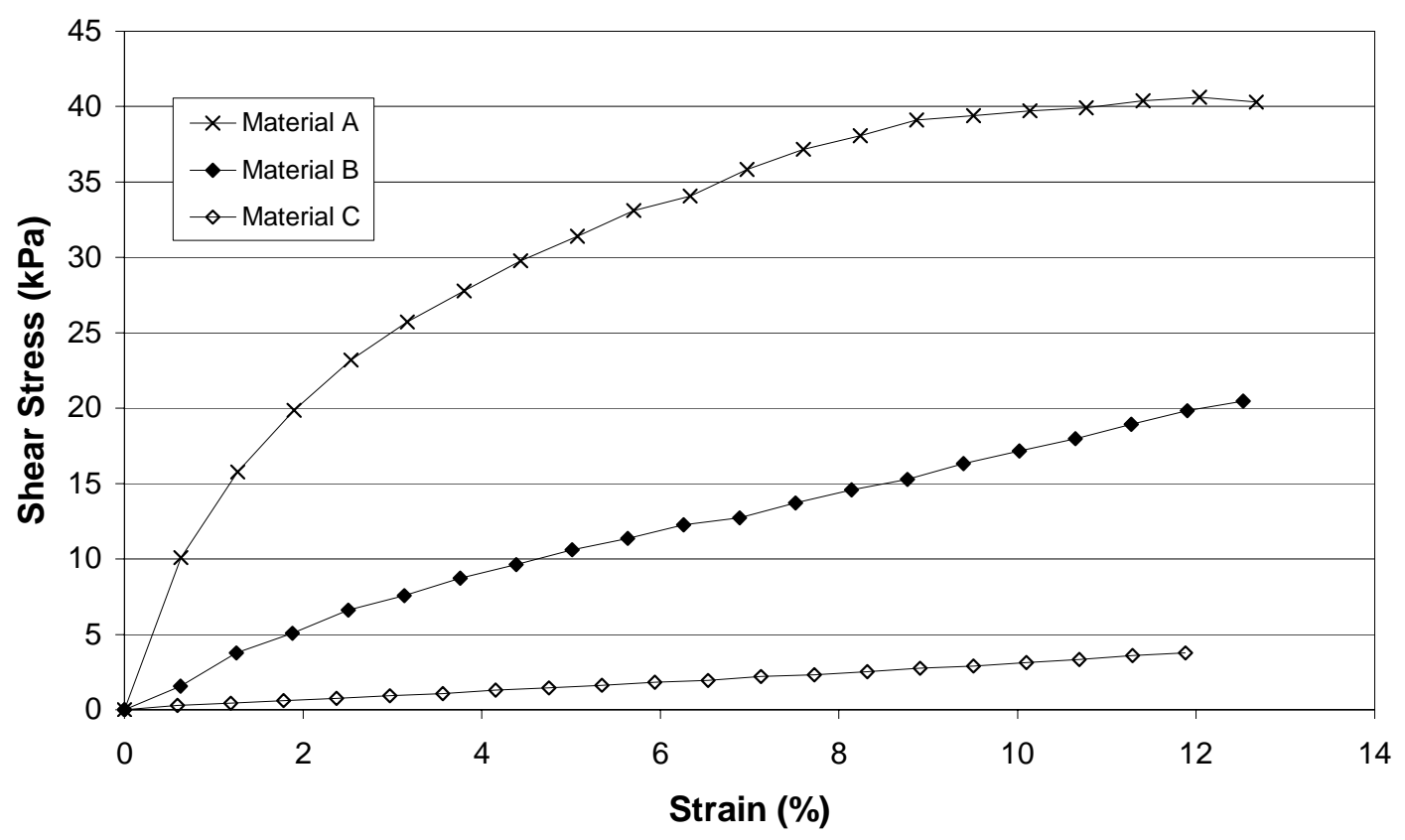

Figure 4.137: Pullout test results for materials A, B, and C-silt interfaces at $S_{n}=103.4 \mathrm{kPa}$ and silt $0 \%$ water content. 
PULLOUT TEST RESULTS

Silt-Geosynthetic Interface, $\sigma_{\mathrm{n}}=103.4 \mathrm{kPa}, 10 \%$ water content

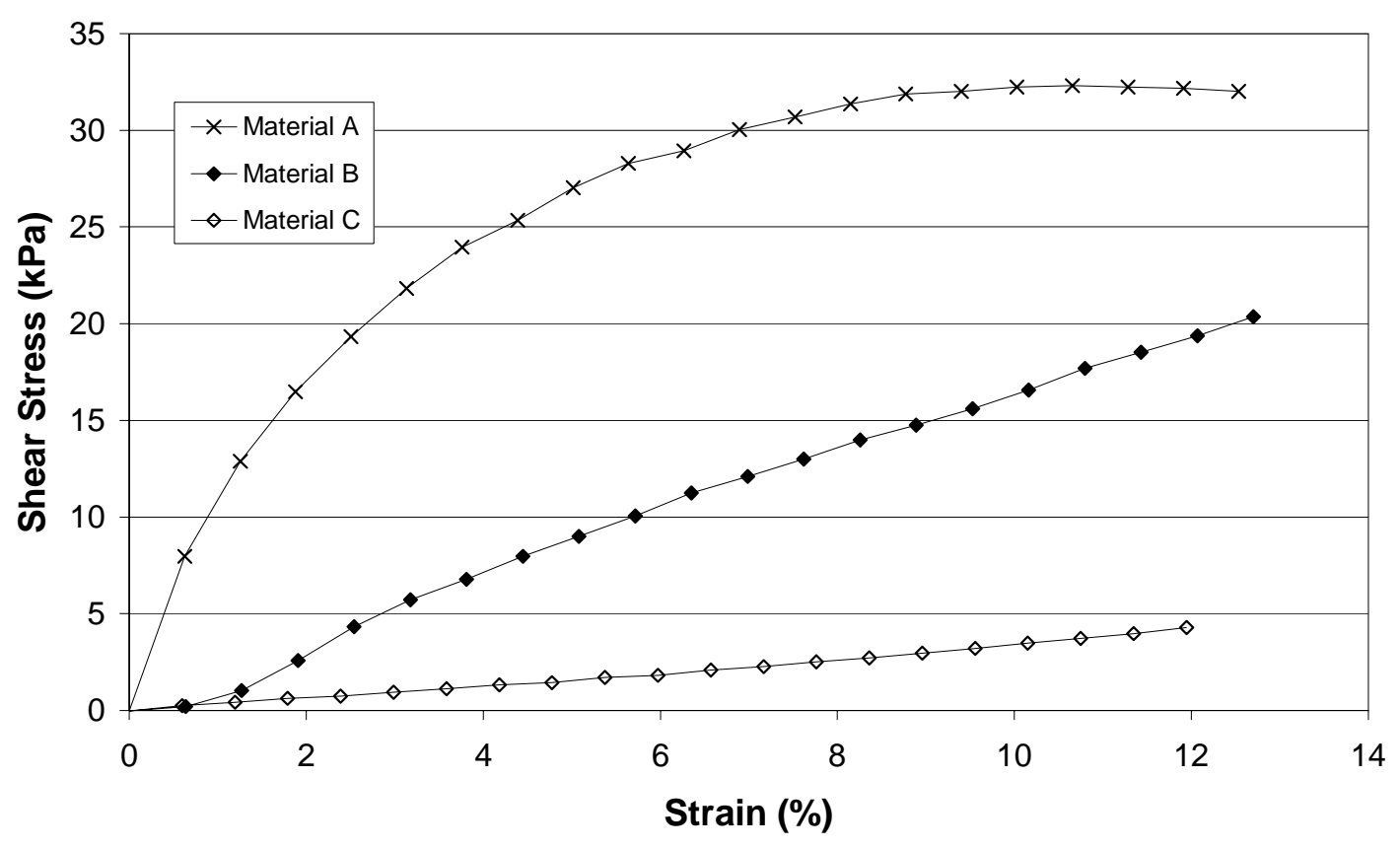

Figure 4.138: Pullout test results for materials A, B, and C-silt interfaces at $S_{n}=103.4 \mathrm{kPa}$ and silt $10 \%$ water content. 


\section{PULLOUT TEST RESULTS}

Silt-Geosynthetic Interface, $\sigma_{\mathrm{n}}=103.4 \mathrm{kPa}, 15 \%$ water content

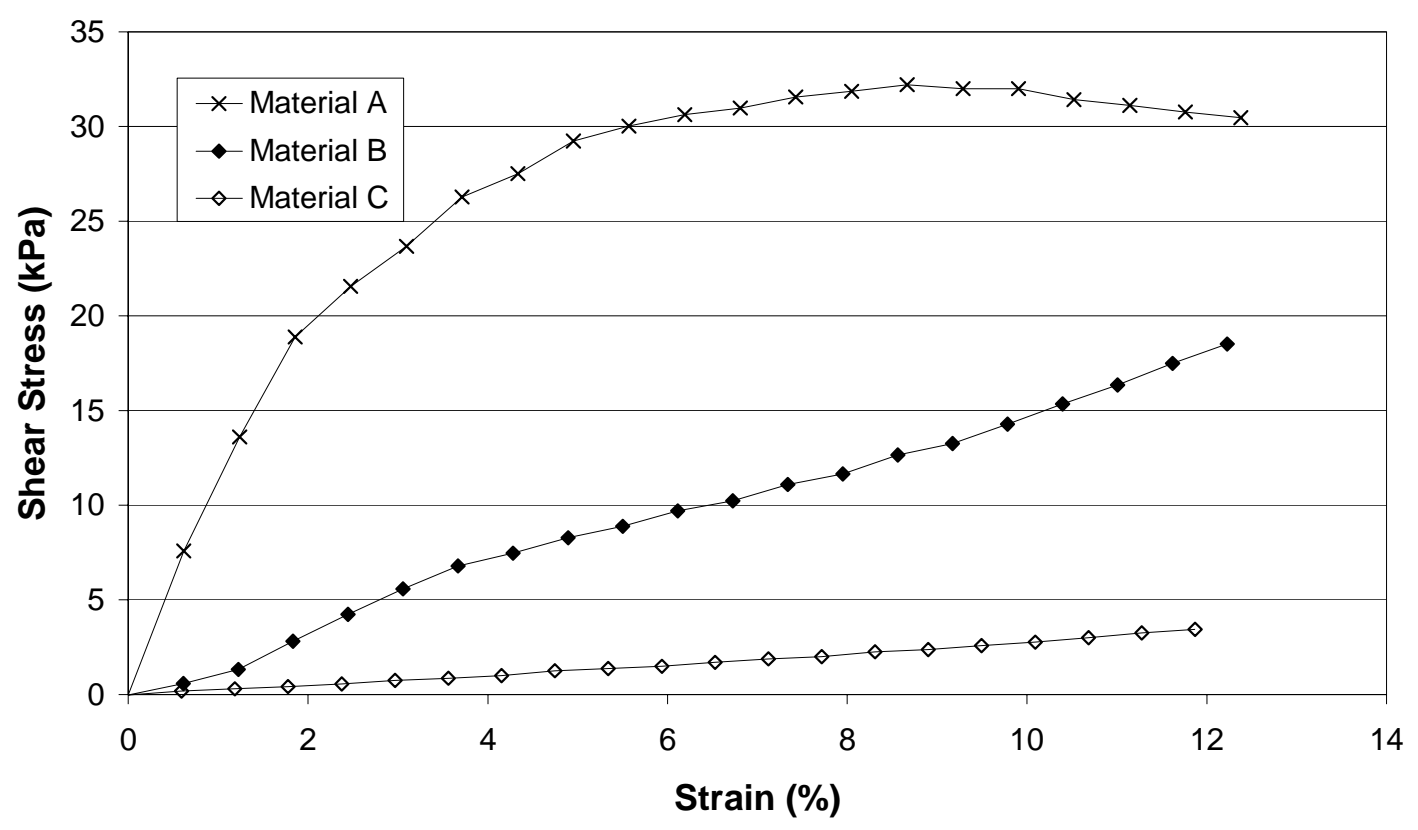

Figure 4.139: Pullout test results for materials A, B, and C-silt interfaces at $S_{n}=103.4 \mathrm{kPa}$ and silt $15 \%$ water content. 


\subsection{Effects of Moisture Content on Pullout Test Results}

Figures 4.140, 4.141 and 4.142 show pullout test results for material A-silt interface at three different normal stresses and $0 \%, 10 \%$ and $15 \%$ water contents. These results consistently show a decrease in shear stress failure values as the water content increases.

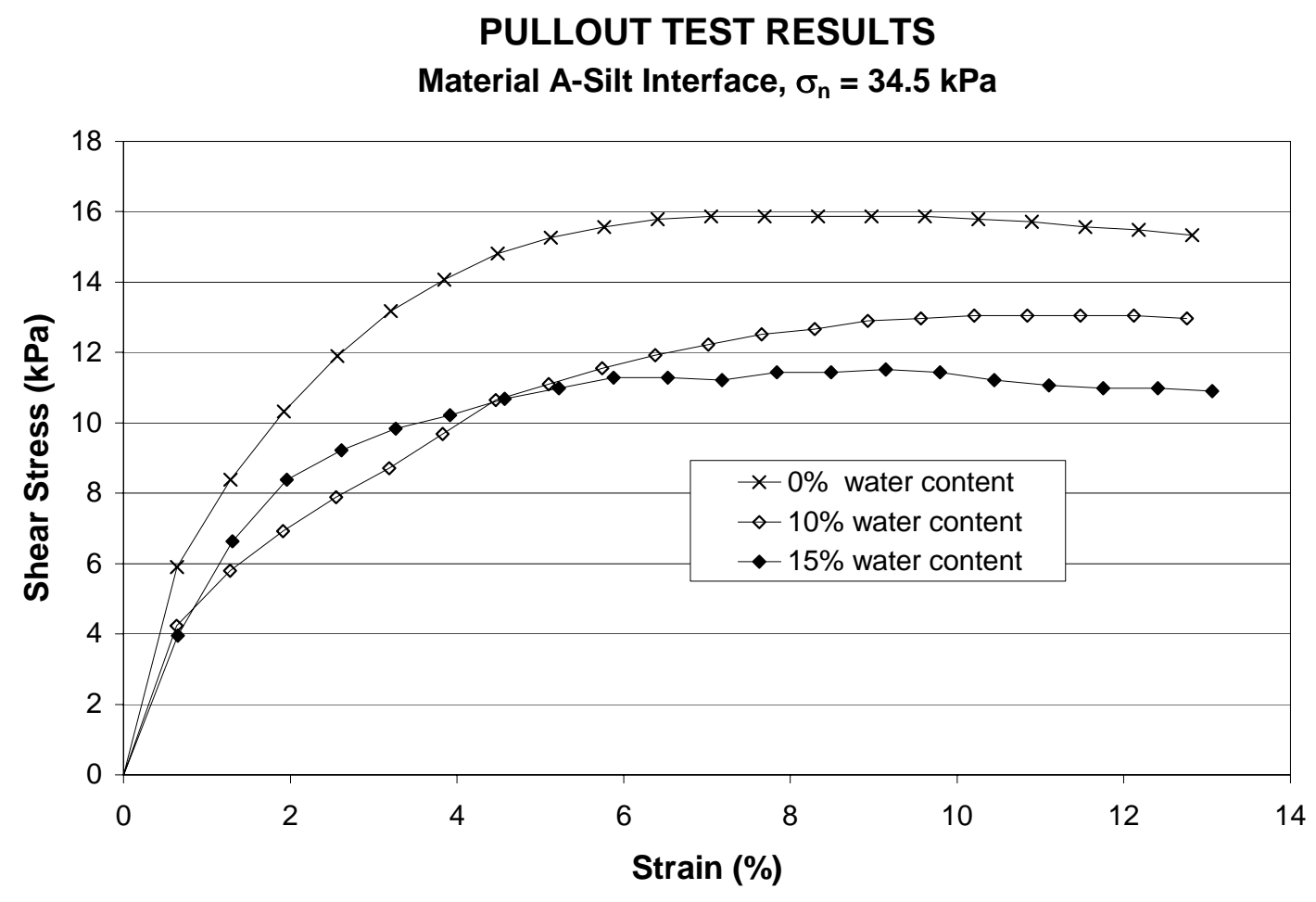

Figure 4.140: Pullout test results for material A-silt interface at 0, 10, and $15 \%$ water contents and $S_{n}=34.5 \mathrm{kPa}$. 


\section{PULLOUT TEST RESULTS}

Material A-Silt Interface, $\sigma_{\mathrm{n}}=69 \mathrm{kPa}$

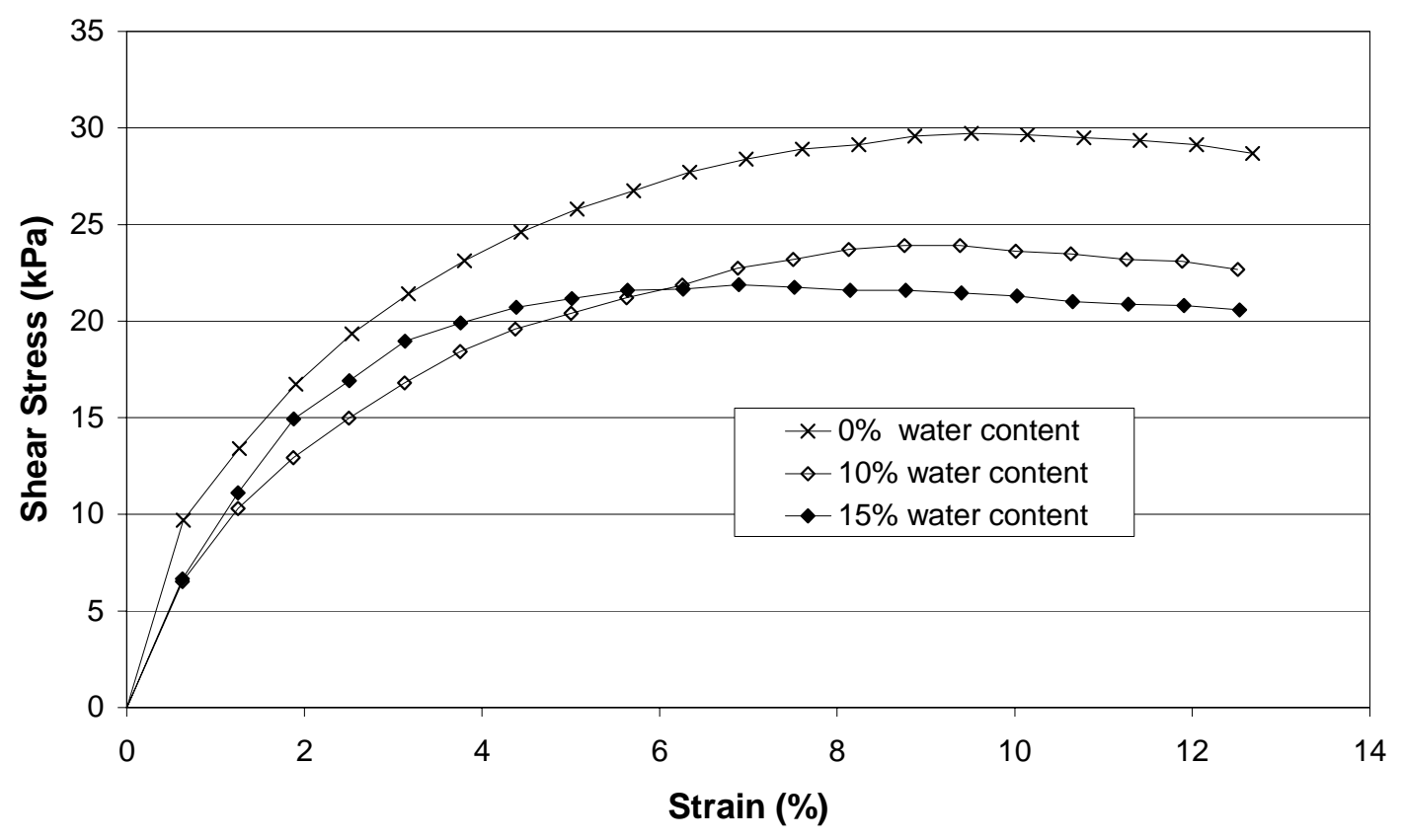

Figure 4.141: Pullout test results for material A-silt interface at 0,10 , and $15 \%$ water contents and $\mathrm{S}_{\mathrm{n}}=69 \mathrm{kPa}$. 


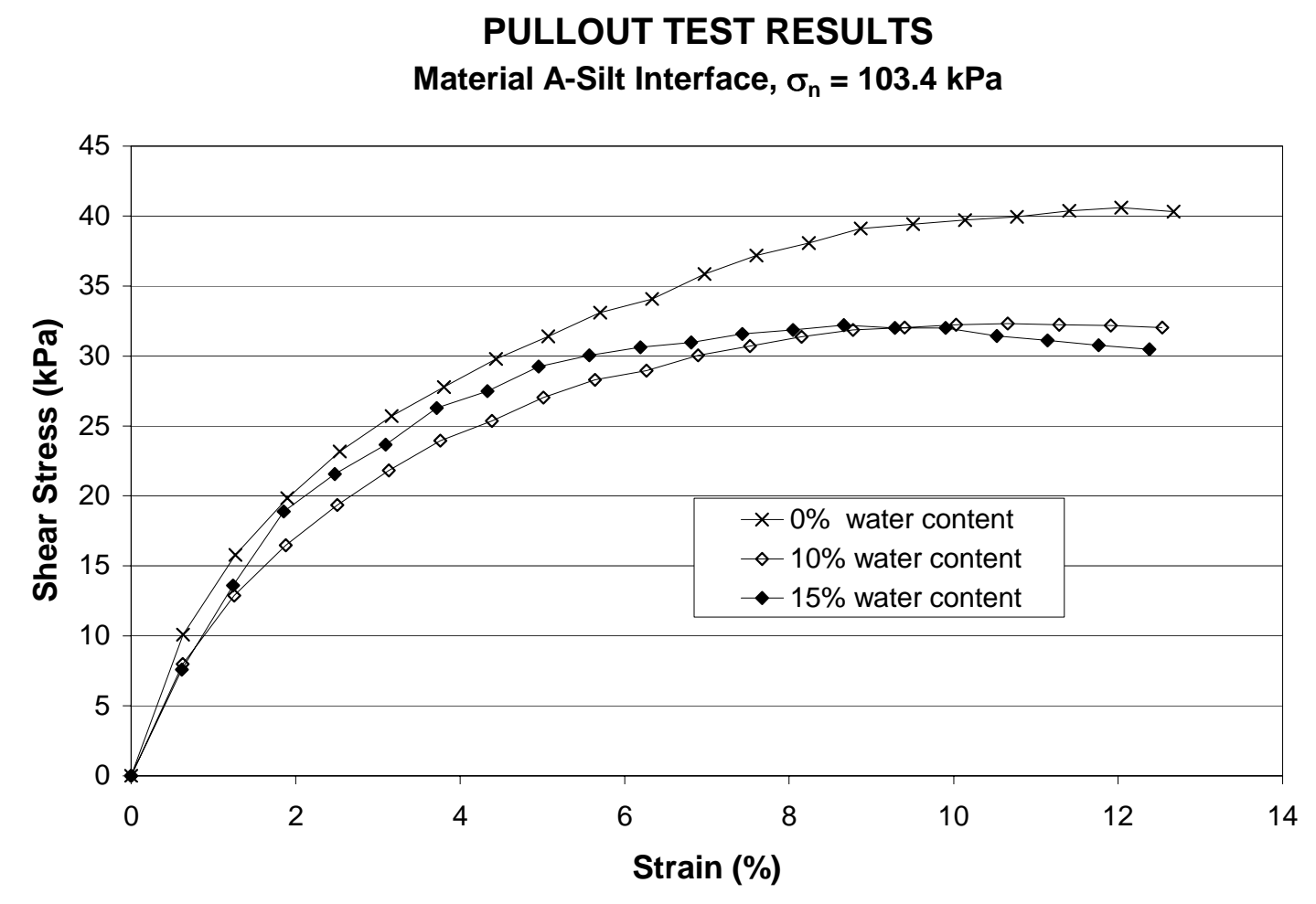

Figure 4.142: Pullout test results for material A-silt interface at 0,10 , and $15 \%$ water contents and $S_{n}=103.4 \mathrm{kPa}$. 
Figures 4.143, 4.144 and 4.145 show pullout test results for material B-silt interface at different normal pressures and water contents of 0, 10 and 15\%. These results illustrate a decrease in shear stress failure values as water content is increased except when using a normal stress of $69 \mathrm{kPa}$. In this case the shear stress failure values for 10 and 15\% water content are very similar in number. However, the shear stress failure value for $15 \%$ water content is higher than that of the $10 \%$ water content.

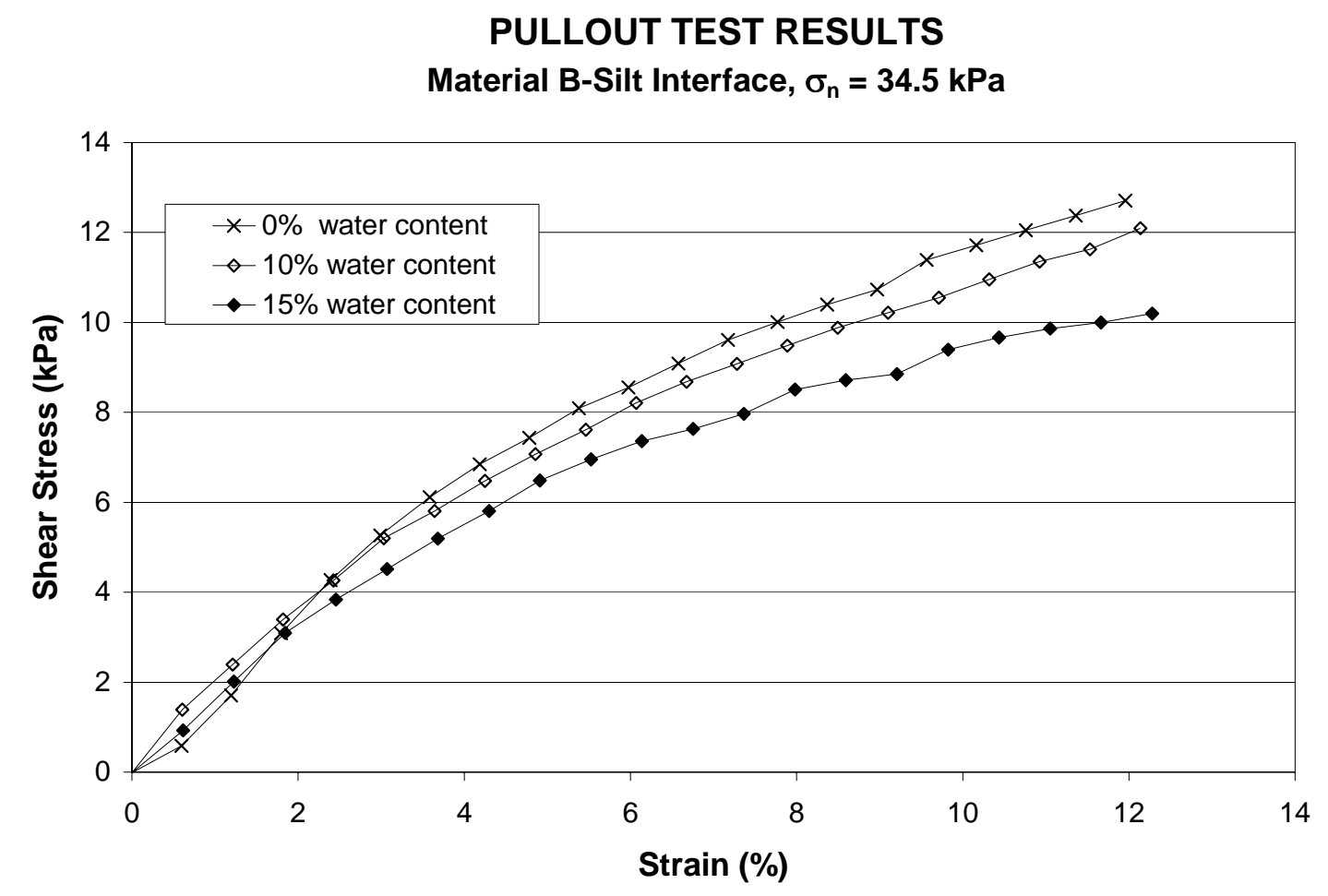

Figure 4.143: Pullout test results for material B-silt interface at $S_{n}=34.5 \mathrm{kPa}$ with 0,10 and $15 \%$ water contents. 


\section{PULLOUT TEST RESULTS}

Material B-Silt Interface, $\sigma_{\mathrm{n}}=69 \mathrm{kPa}$

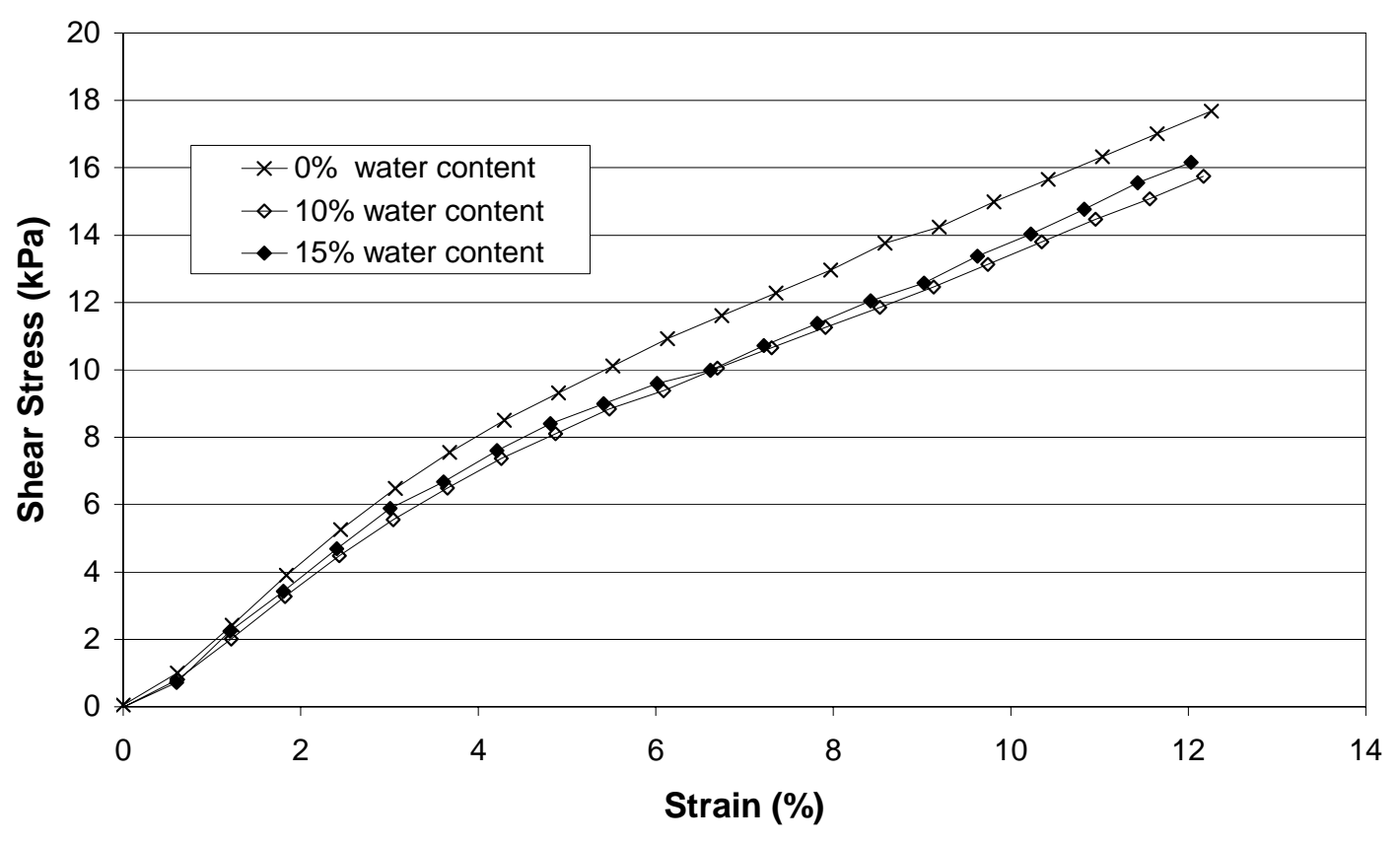

Figure 4.144: Pullout test results for material B-silt interface at $S_{n}=69 \mathrm{kPa}$ with 0,10 and $15 \%$ water contents. 
PULLOUT TEST RESULTS

Material B-Silt Interface, $\sigma_{\mathrm{n}}=103.4 \mathrm{kPa}$

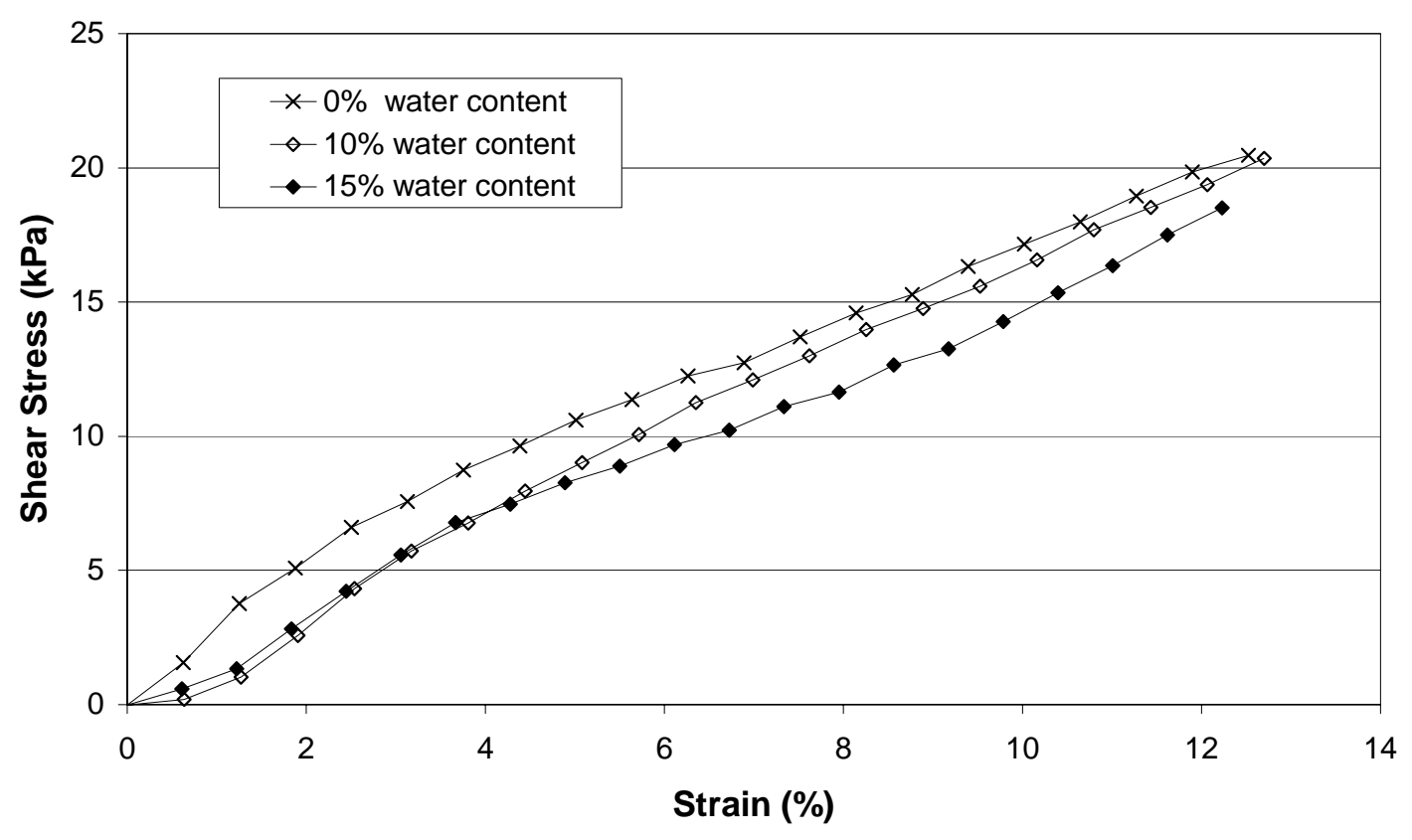

Figure 4.145: Pullout test results for material B-silt interface at $S_{n}=103.4 \mathrm{kPa}$ with 0,10 and $15 \%$ water contents. 
Figures 4.146, 4.147 and 4.148 show pullout test results for material C-silt interface with different normal stresses and at 0,10 and 15\% water content. These results do not show any consistent influences of water content on interface properties.

\section{PULLOUT TEST RESULTS}

\section{Material C-Silt Interface, $S_{n}=34.5 \mathrm{kPa}$}

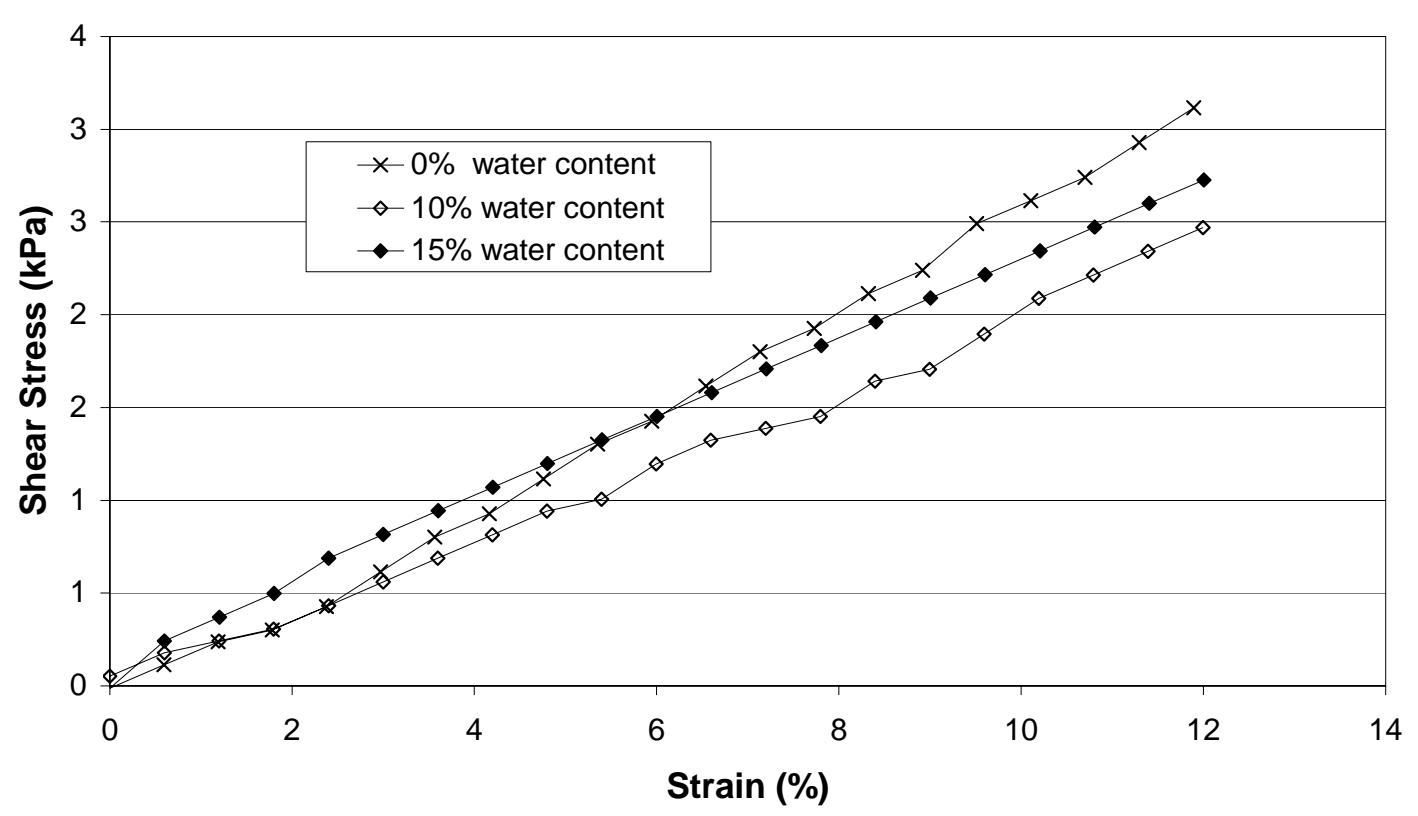

Figure 4.146: Pullout test results for material C-silt interface at $S_{n}=34.5 \mathrm{kPa}$ with 0,10 and $15 \%$ water contents. 
PULLOUT TEST RESULTS

Material C-Silt Interface, $S_{n}=69 \mathrm{kPa}$

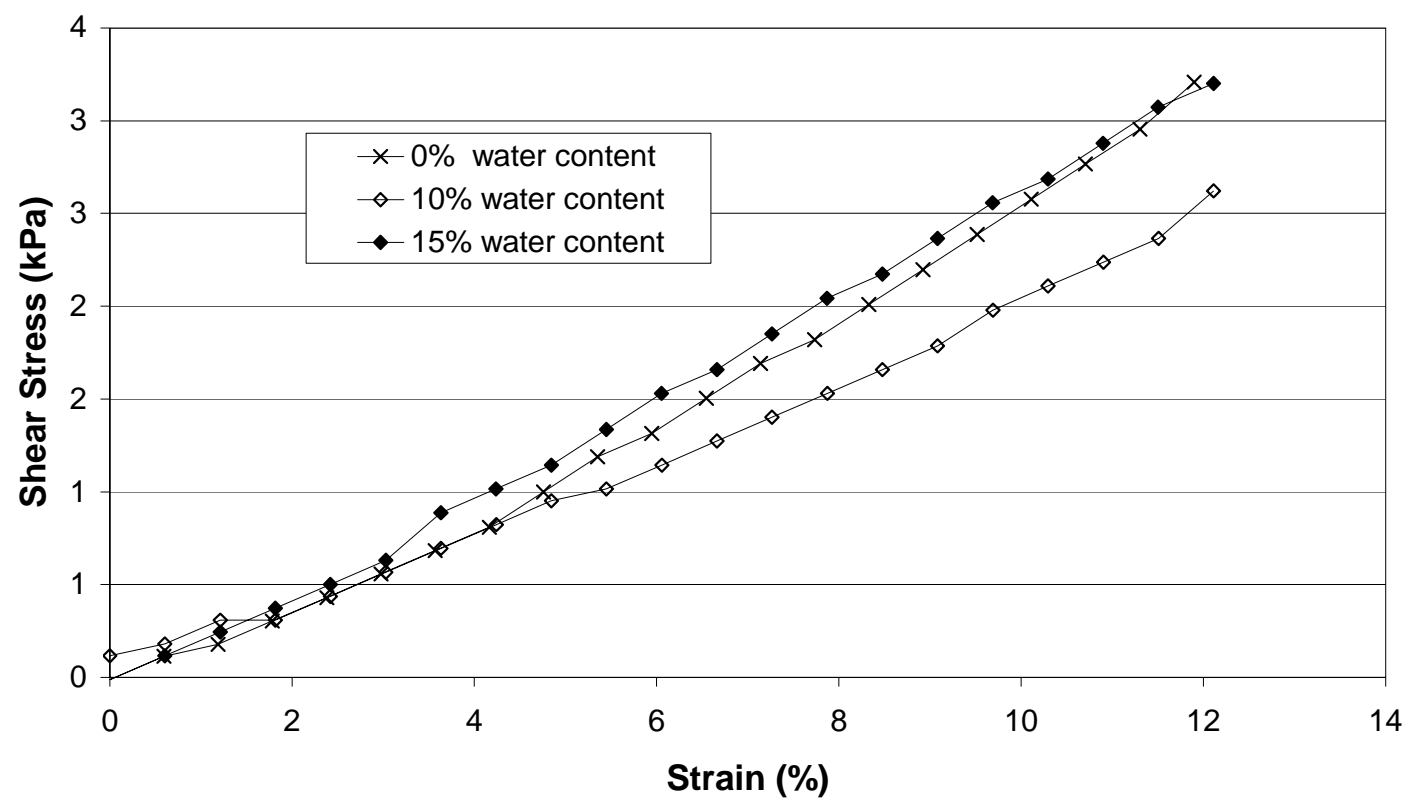

Figure 4.147: Pullout test results for material $C$-silt interface at $S_{n}=69 \mathrm{kPa}$ with 0,10 and $15 \%$ water contents. 
PULLOUT TEST RESULTS

\section{Material C-Silt Interface, $S_{n}=103.4 \mathrm{kPa}$}

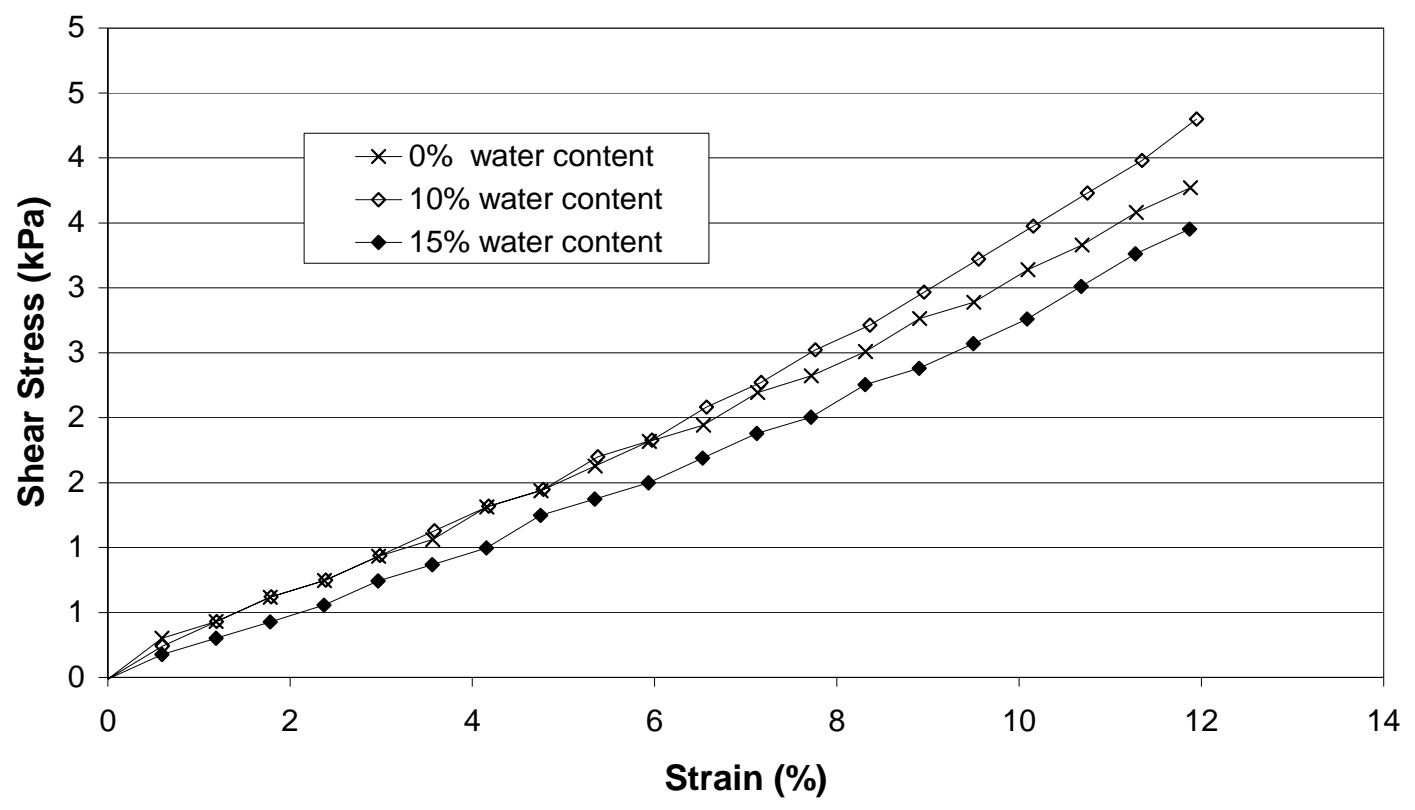

Figure 4.148: Pullout test results for material $C$-silt interface at $S_{n}=103.4 \mathrm{kPa}$ with 0,10 and $15 \%$ water contents. 
Material B was the only geosynthetic tested using sand, silt and clay. Figures 4.149, 4.150 and 4.151 show the pullout test results for these interfaces under different normal stresses and with water contents of 0,10 and $15 \%$. These results show a decrease in shear stress failure values as water content of the soil increases except under a low normal stress.

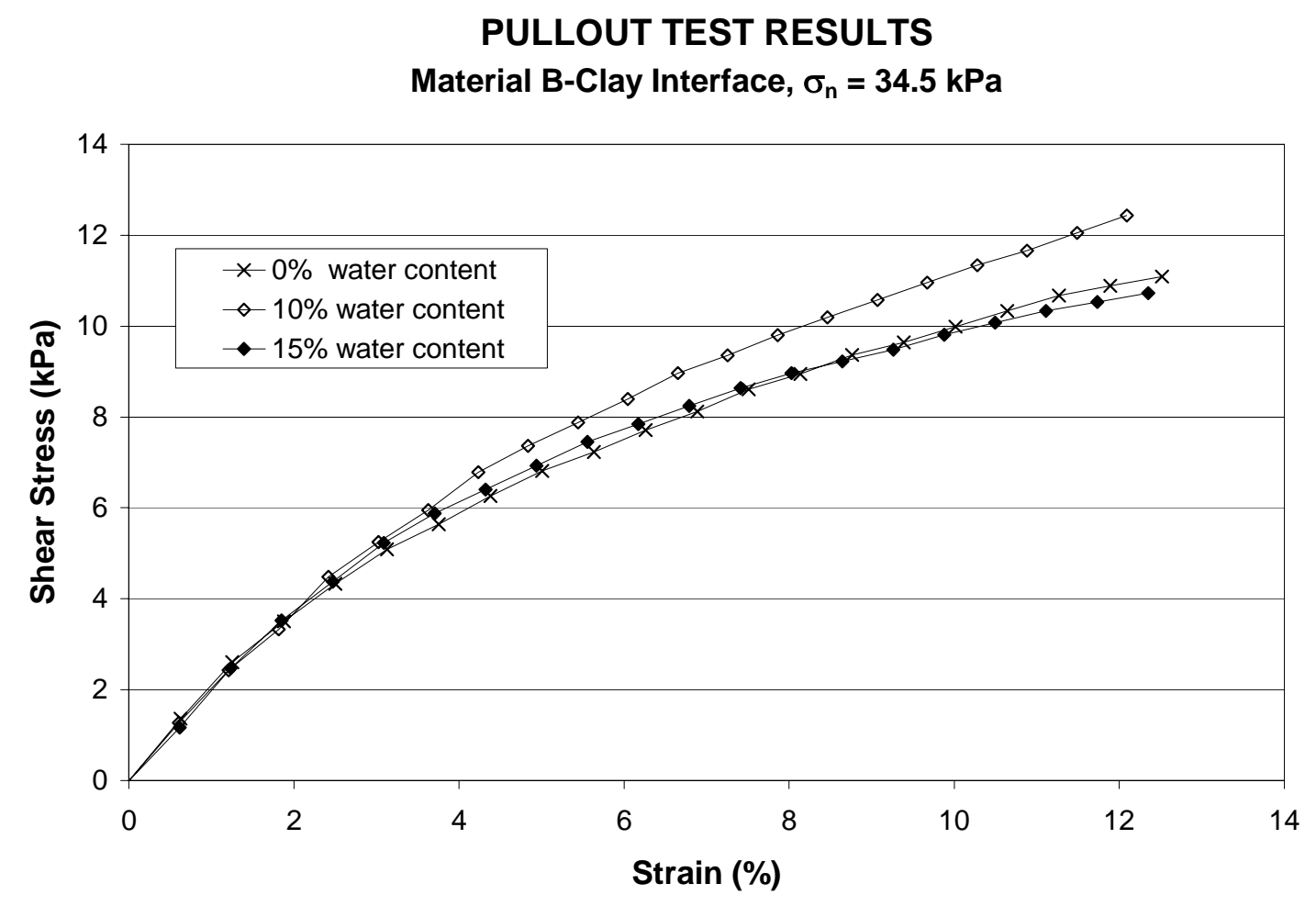

Figure 4.149: Pullout test results for material B-clay interface at $S_{n}=35.4 \mathrm{kPa}$ and 0,10 and $15 \%$ water contents. 


\section{PULLOUT TEST RESULTS}

Material B-Clay Interface, $\sigma_{\mathrm{n}}=69 \mathrm{kPa}$

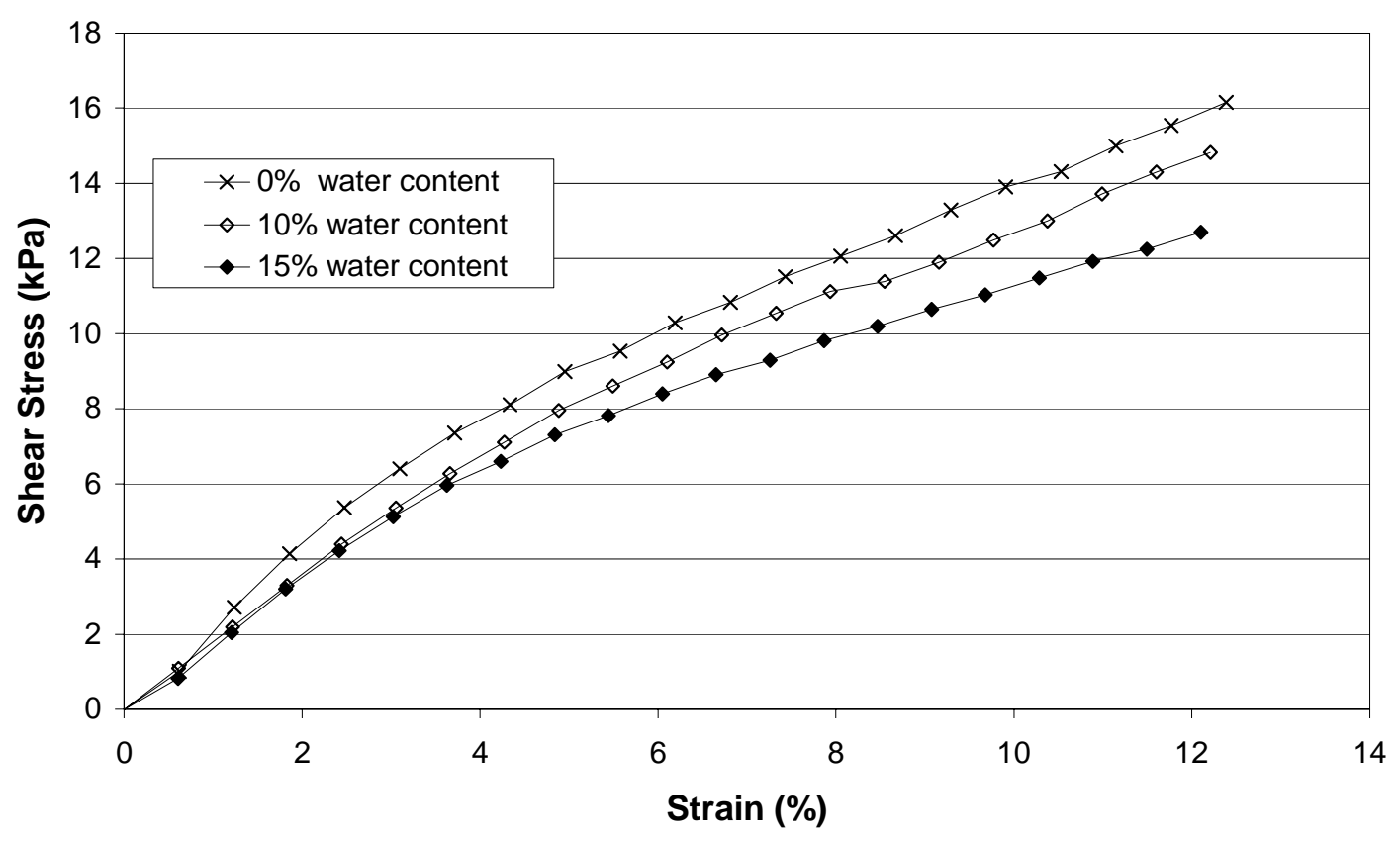

Figure 4.150: Pullout test results for material B-clay interface at $S_{n}=69 \mathrm{kPa}$ and 0,10 and $15 \%$ water contents. 


\section{PULLOUT TEST RESULTS}

Material B-Clay Interface, $\sigma_{\mathrm{n}}=103.4 \mathrm{kPa}$

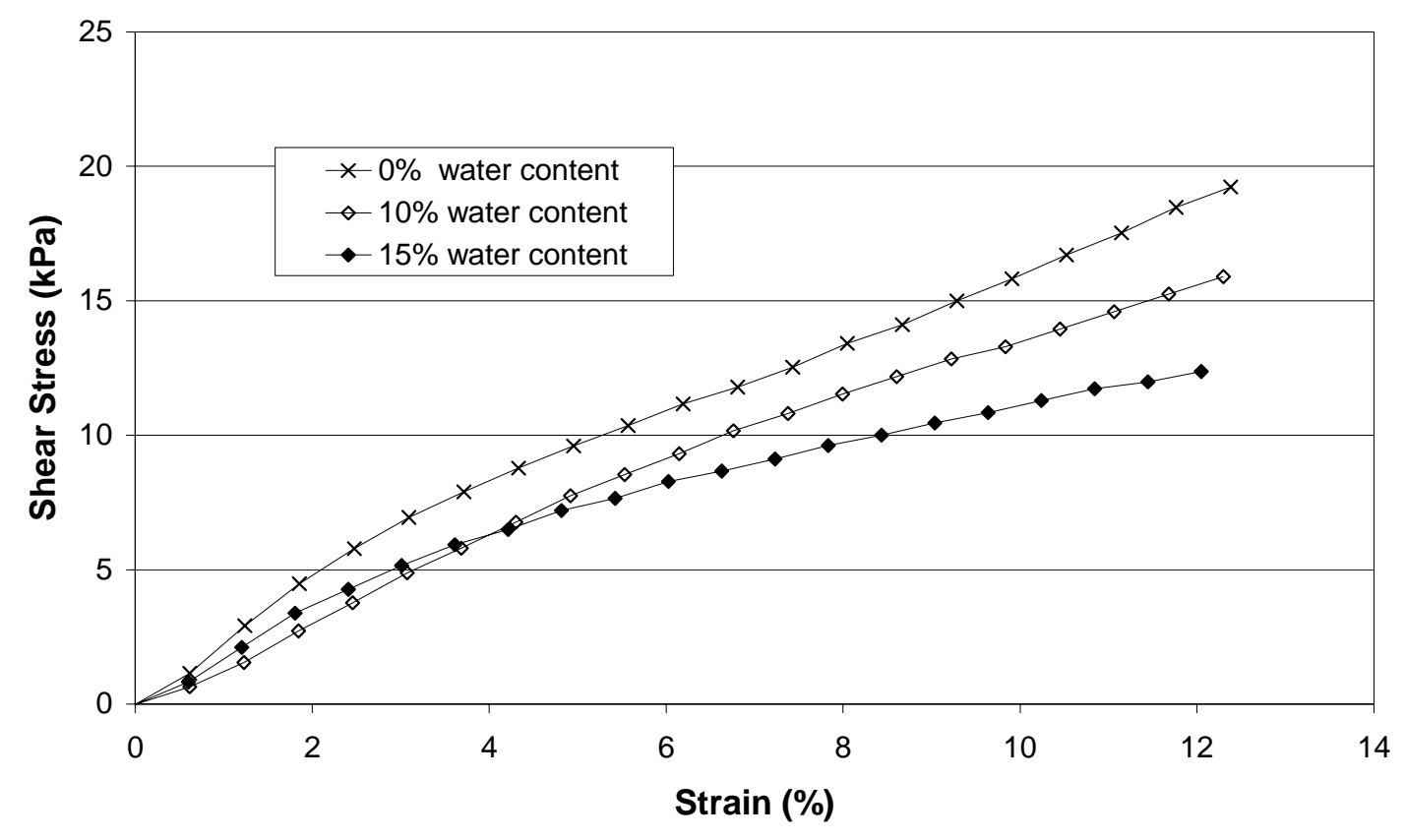

Figure 4.151: Pullout test results for material B-clay interface at $S_{n}=103.4 \mathrm{kPa}$ and 0,10 and $15 \%$ water contents. 


\subsection{Comparison of Direct Shear and Pullout Test Results}

This section compares the direct shear test results with the pullout test results. All comparisons done are with a sand-geosynthetic interface. This is because sand was the only soil tested with geosynthetics in direct shear testing. The normal stresses used for

pullout testing were $34.5 \mathrm{kPa}$ (5 psi), $69 \mathrm{kPa}$ (10 psi) and $103.4 \mathrm{kPa}(15 \mathrm{psi})$. The normal stresses used for direct shear testing were $35.3 \mathrm{kPa}$ (5.1 psi), $69.6 \mathrm{kPa}$ (10.1 psi) and $103.9 \mathrm{kPa}$ (15.1 psi). There direct shear normal stresses were used because they were the closest values to the pullout normal stresses that could be reached. The difference is small enough to neglect and the average of the two normal stress values will be used in this section; $34.9 \mathrm{kPa}$ (5.06 psi), $69.3 \mathrm{kPa}$ (10.05 psi) and $103.9 \mathrm{kPa}$ (15.07 psi).

Figures 4.152, 4.153 and 4.154 compare the pullout and direct shear test results for the three geosynthetic materials at the same normal stress. When comparing the geosynthetics at the same normal stresses the direct shear stress failure values are more similar to each other than the pullout shear stress failure values. 
COMPARISON OF PULLOUT AND DIRECT SHEAR TEST RESULTS

Geosynthetic-Sand Interface, $\sigma_{\mathrm{n}}=34.9 \mathrm{kPa}$

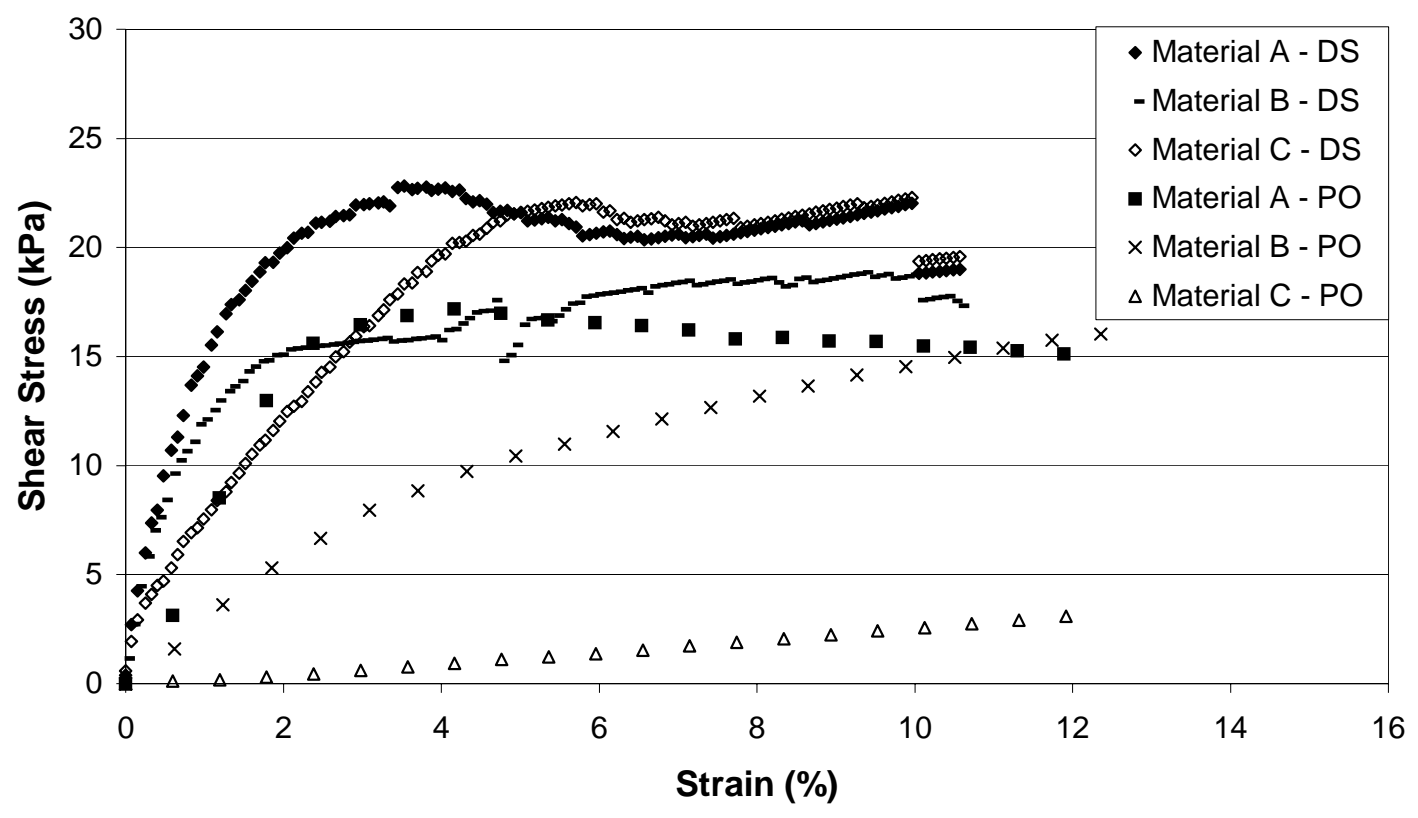

Figure 4.152: Pullout and direct shear test results for geosynthetic-sand interfaces at $\mathrm{S}_{\mathrm{n}}=$ 34.9 kPa. 


\section{COMPARISON OF PULLOUT AND DIRECT SHEAR TEST RESULTS}

Geosynthetic-Sand Interface, $\sigma_{n}=69.3 \mathrm{kPa}$

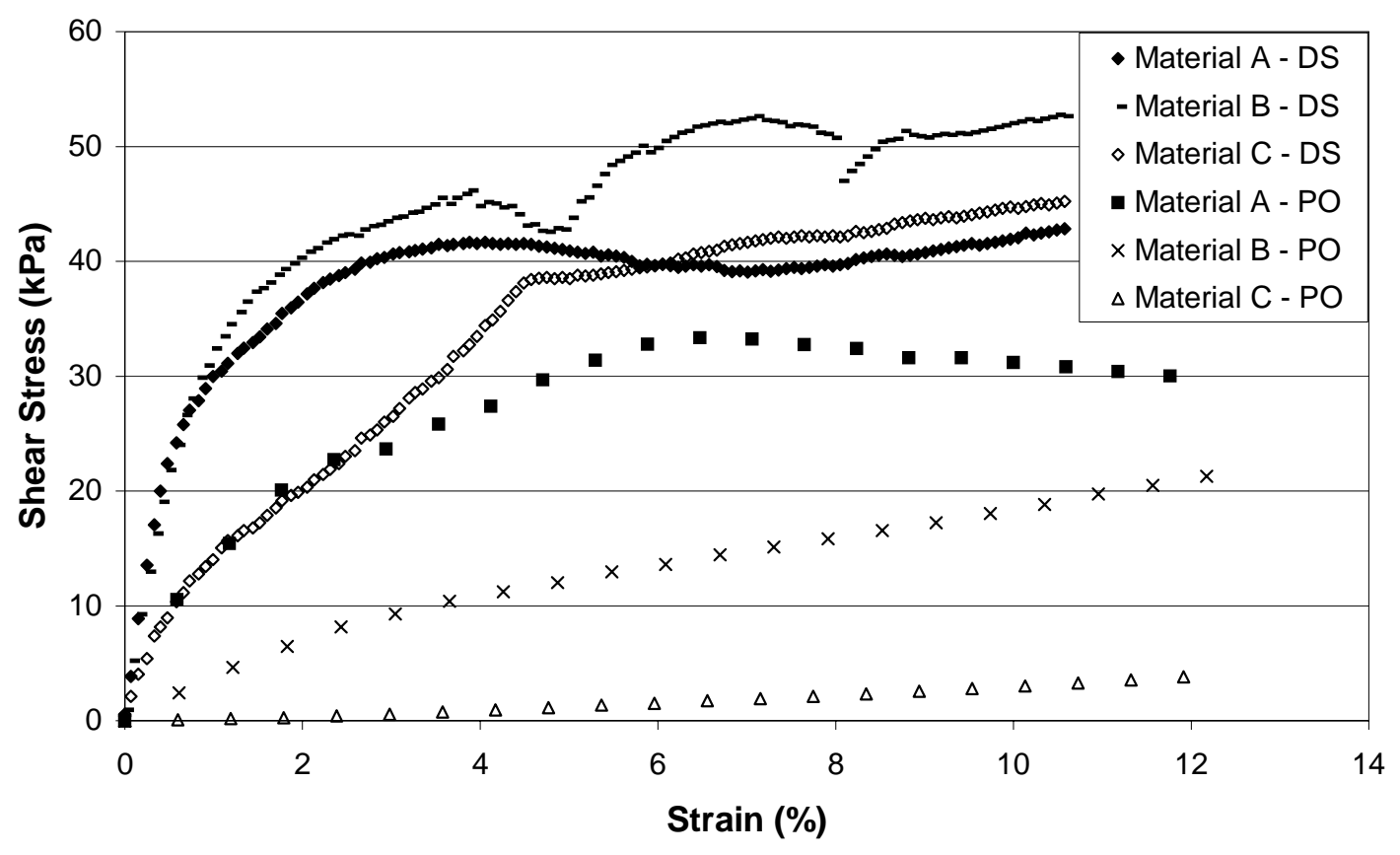

Figure 4.153: Pullout and direct shear test results geosynthetic-sand interfaces at $S_{n}=69.3$ kPa. 
COMPARISON OF PULLOUT AND DIRECT SHEAR TEST RESULTS Geosynthetic-Sand Interface, $\sigma_{\mathrm{n}}=103.7 \mathrm{kPa}$

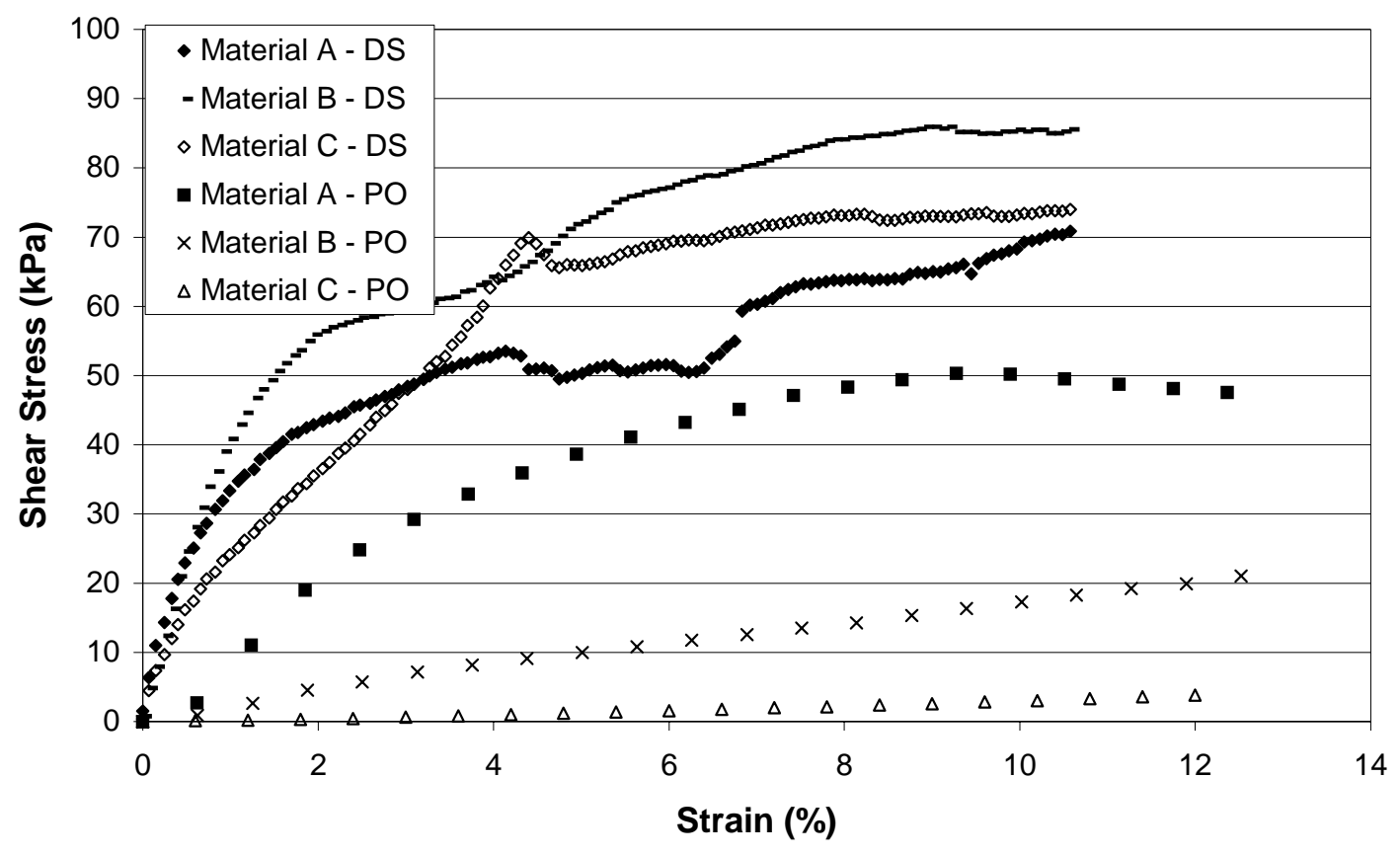

Figure 4.154: Pullout and direct shear results for geosynthetic-sand interfaces at $S_{n}=103.7$ kPa. 
Figures 4.155, 4.156 and 4.157 compare pullout and direct shear test results. Each graph compares a different geosynthetic material at all three normal stresses. The pullout shear stress failure values seem to drop dramatically as the geosynthetic tensile strength decreases. However, the direct shear failure values do not.

\section{COMPARISON OF PULLOUT AND DIRECT SHEAR TEST RESULTS Material A-Sand Interface}

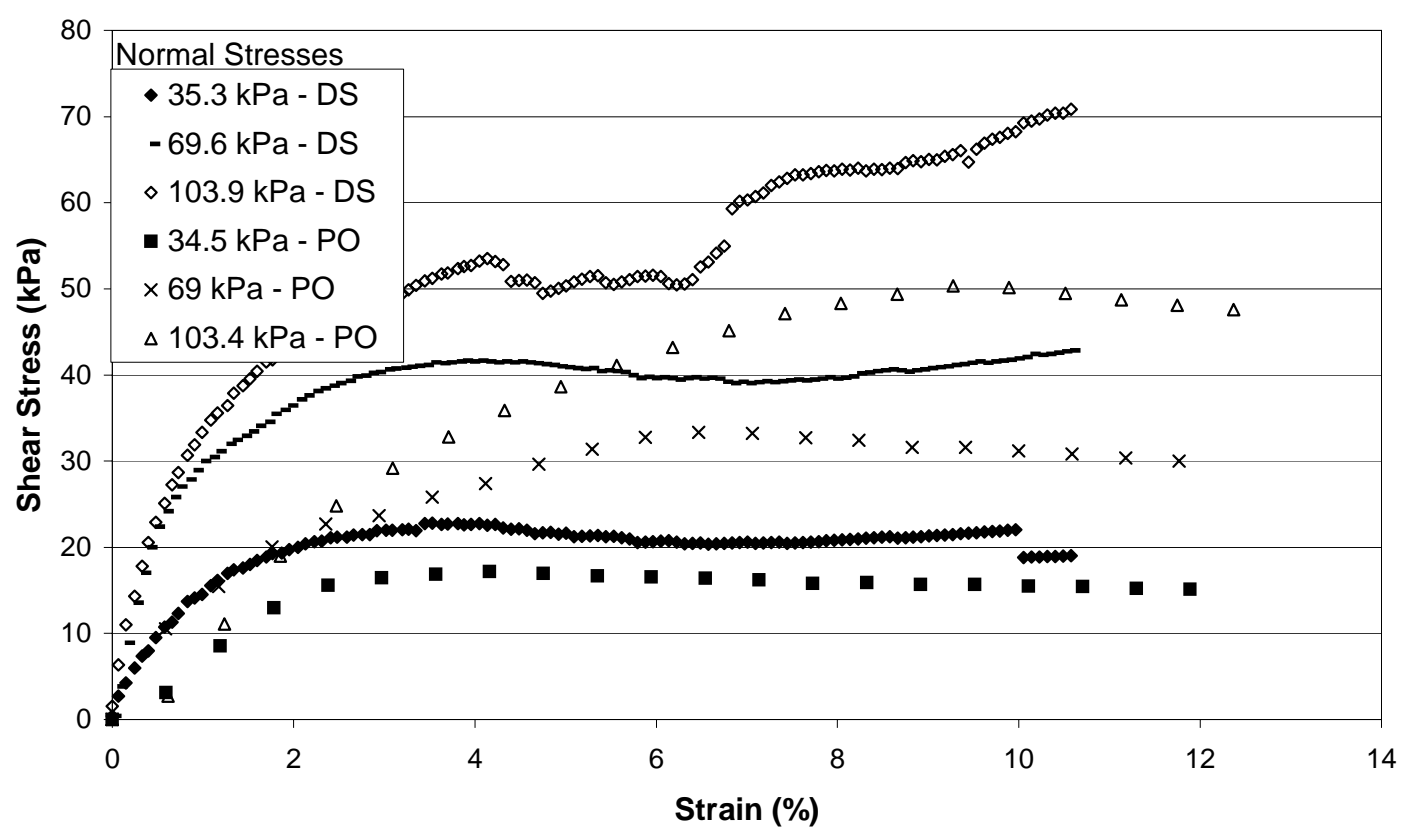

Figure 4.155: Pullout and direct shear test results for material A -sand interface with $0 \%$ water content. 


\section{COMPARISON OF PULLOUT AND DIRECT SHEAR TEST RESULTS}

\section{Material B-Sand Interface}

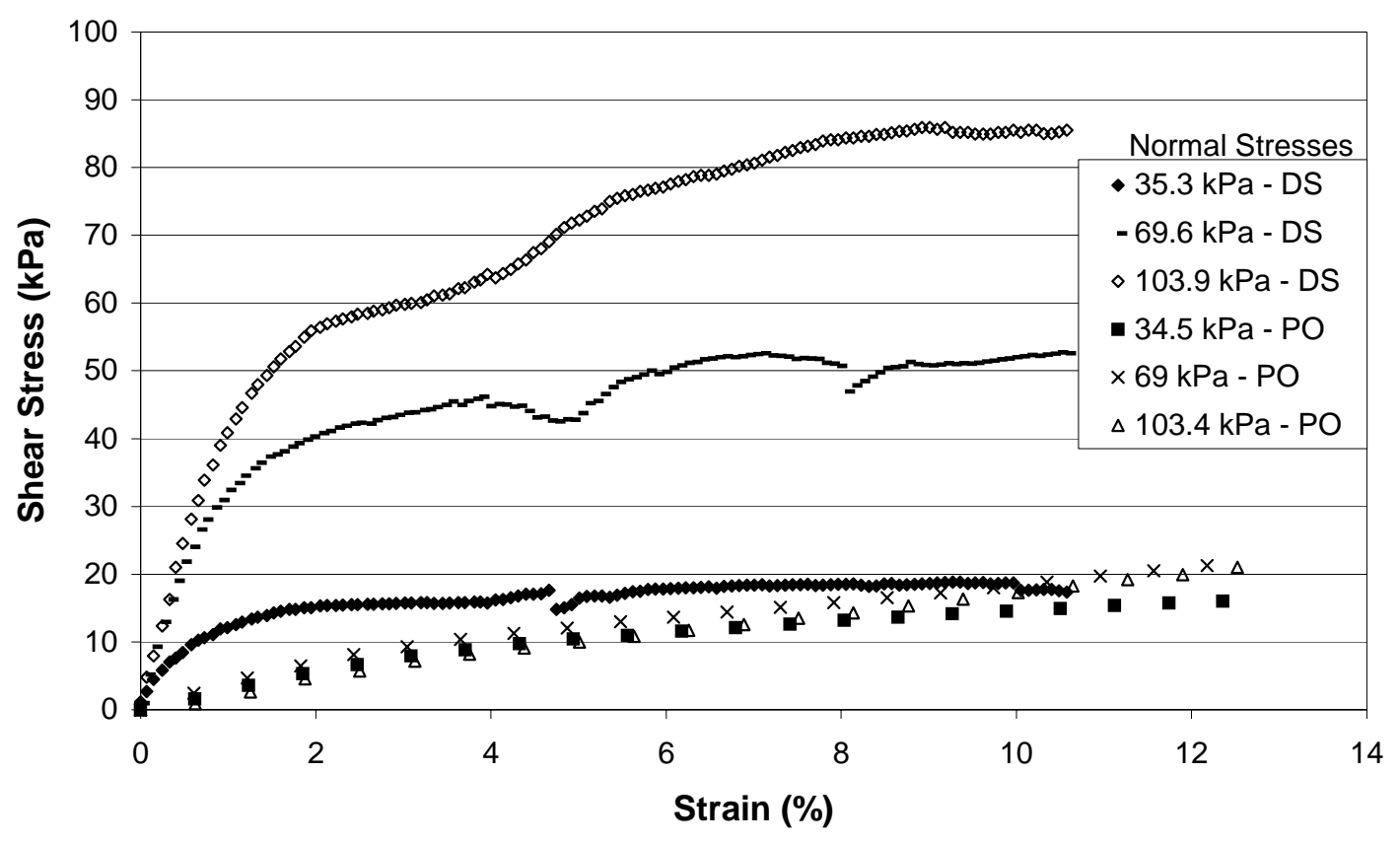

Figure 4.156: Pullout and direct shear test results for material B-sand interface with $0 \%$ water content. 


\section{COMPARISON OF PULLOUT AND DIRECT SHEAR TEST RESULTS Material C-Sand Interface}

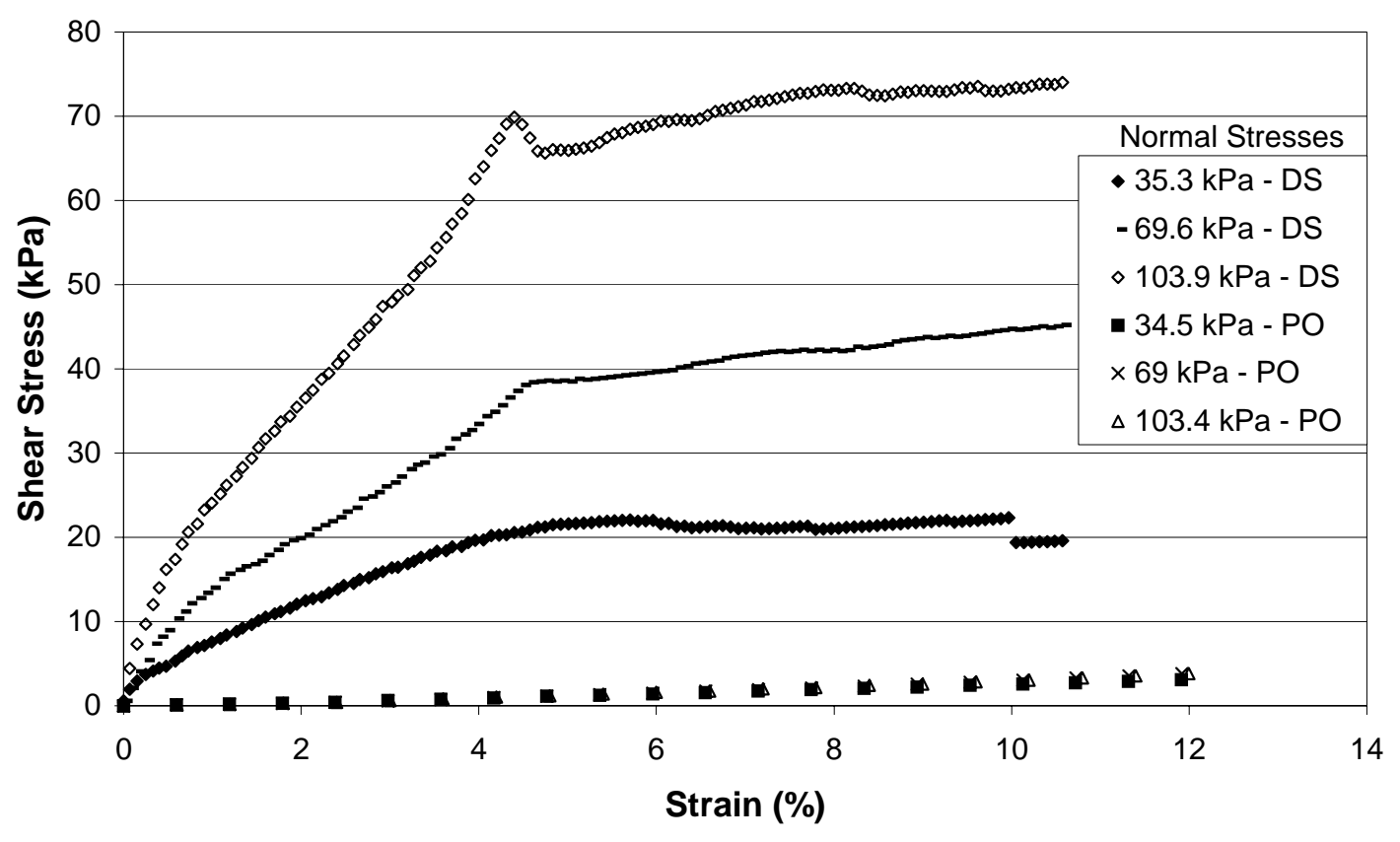

Figure 4.157: Pullout and direct shear test results for material C -sand interface with $0 \%$ water content. 


\section{CHAPTER 5: SUMMARY AND CONCLUSIONS}

\subsection{Summary}

The purpose of this study was to investigate soil-geosynthetic interface properties. This was done using a laboratory test program consisting of direct shear and pullout testing. These tests were used to find the angle of friction, effective cohesion and shear stress values at failure of the interfaces. Knowing these interface properties is essential for the investigation. Three geosynthetics were used for direct shear and pullout testing. Two of these geosynthetics were geogrids (material A and B). The third geosynthetic material was a geotextile (material C). Properties of these geosynthetics can be found in Table 3.1.

Direct shear testing consisted of different interface combinations sand, silt and clay soils and three different geosynthetic materials were tested using dry sand. These geosynthetics are referred to as material A, B and C. The soil-soil interfaces were tested at 0,10 and $15 \%$ water content. Each of these interfaces was run at a minimum of three different normal stresses: $35.3 \mathrm{kPa}$ (5.1 psi), $69.6 \mathrm{kPa}$ (10.1 psi) and $103.9 \mathrm{kPa}$ (15.1 psi). Each specimen configuration was run twice, to ensure reliability, and a new geosynthetic sample was used for each test.

Two pullout devices one with box dimensions of $18^{\prime \prime} \times 12^{\prime \prime} \times 6^{\prime \prime}(45.7 \mathrm{~cm} \times 30.5$ $\mathrm{cm} \times 15.2 \mathrm{~cm})$ and another with box dimensions of 48" x 18" x 6" $(122 \mathrm{~cm} \times 45.7 \mathrm{~cm} \times$ $15.2 \mathrm{~cm}$ ) were designed and built specifically for this study. This was done to explore the effects of specimen size and boundary conditions. The smaller pullout box was referred to as pullout box A and the larger was referred to as pullout box B. Instrumentation for measuring load and displacement was completed. The normal stress on the soilgeosynthetic interface was applied by using rubber airbags. These airbags were built to fit the pullout devices. A clamping mechanism was designed to prevent synthetic/clamp separation. A guide system was positioned to avoid rotation of the clamp/geosynthetic unit during testing.

Three soils were used for pullout testing: sand, silt and clay. The silt and clay were tested at three different water contents (0,10 and 15\%). Each interface was also run at 
three normal stresses: $34.5 \mathrm{kPa}$ (5 psi), $69 \mathrm{kPa}$ (10 psi) and $103.4 \mathrm{kPa}(15 \mathrm{psi})$. Each specimen configuration was run twice and a new geosynthetic sample was used for each test. A summary of results can be found in Table 5.1. This includes geosynthetic material properties and direct shear and pullout angles of friction and effective cohesions. 
Table 5.1: Summary of direct shear and pullout test results with geosynthetic material properties

\begin{tabular}{|c|c|c|c|c|c|c|c|c|c|c|}
\hline \multirow[b]{2}{*}{$\begin{array}{c}\text { Geosynthetic } \\
\text { Material }\end{array}$} & \multirow[b]{2}{*}{$\begin{array}{c}\text { Tensile } \\
\text { Strength } \\
(\mathrm{kN} / \mathrm{m})\end{array}$} & \multirow{2}{*}{$\begin{array}{c}\text { Grid } \\
\text { Aperture } \\
\text { Size, MD } \\
(\mathrm{mm})\end{array}$} & \multirow{2}{*}{$\begin{array}{c}\text { Grid } \\
\text { Aperture } \\
\text { Size, } \\
\text { XMD } \\
(\mathrm{mm})\end{array}$} & \multirow[b]{2}{*}{$\begin{array}{c}\text { Mass per } \\
\text { Unit Area } \\
\left(\mathrm{g} / \mathrm{m}^{2}\right)\end{array}$} & \multirow[b]{2}{*}{$\begin{array}{l}\text { Soil } \\
\text { Type }\end{array}$} & \multirow[b]{2}{*}{$\begin{array}{c}\text { Water } \\
\text { Content } \\
(\%)\end{array}$} & \multicolumn{2}{|c|}{ PULLOUT } & \multicolumn{2}{|c|}{ DIRECT SHEAR } \\
\hline & & & & & & & $\begin{array}{c}\text { Angle of } \\
\text { Friction } \\
\text { (degrees) }\end{array}$ & $\begin{array}{c}\text { Effective } \\
\text { Cohesion } \\
(\mathrm{kPa})\end{array}$ & $\begin{array}{l}\text { Angle of } \\
\text { Friction } \\
\text { (degrees) }\end{array}$ & $\begin{array}{c}\text { Effective } \\
\text { Cohesion } \\
(\mathrm{kPa})\end{array}$ \\
\hline \multirow{4}{*}{$A$} & \multirow{4}{*}{120} & \multirow{4}{*}{65} & \multirow{4}{*}{20} & \multirow{4}{*}{415} & Sand & 0 & 26.01 & 0 & 25.4 & 0 \\
\hline & & & & & \multirow{3}{*}{ Silt } & 0 & 19.21 & 4.5 & - & - \\
\hline & & & & & & 10 & 15.46 & 3.9 & - & - \\
\hline & & & & & & 15 & 16.78 & 1.1 & - & - \\
\hline \multirow{7}{*}{ B } & \multirow{7}{*}{35} & \multirow{7}{*}{40} & \multirow{7}{*}{25} & \multirow{7}{*}{170} & Sand & 0 & 12.21 & 0 & 31.5 & 0 \\
\hline & & & & & \multirow{3}{*}{ Silt } & 0 & 4.22 & 9.3 & - & - \\
\hline & & & & & & 10 & 5.00 & 7.4 & - & - \\
\hline & & & & & & 15 & 4.06 & 7.5 & - & - \\
\hline & & & & & \multirow{3}{*}{ Clay } & 0 & 4.60 & 7.4 & - & - \\
\hline & & & & & & 10 & 1.94 & 9.9 & - & - \\
\hline & & & & & & 15 & 1.01 & 9.4 & - & - \\
\hline \multirow{4}{*}{ C } & \multirow{4}{*}{0.36} & \multirow{4}{*}{ N/A } & \multirow{4}{*}{ N/A } & \multirow{4}{*}{$310^{*}$} & Sand & 0 & 2.11 & 0 & 29.5 & 0 \\
\hline & & & & & \multirow{3}{*}{ Silt } & 0 & 0.33 & 2.19 & - & - \\
\hline & & & & & & 10 & 1.10 & 1.1 & - & - \\
\hline & & & & & & 15 & 0.29 & 2.1 & - & - \\
\hline \multirow{3}{*}{\multicolumn{6}{|c|}{ Sand-Sand Interface }} & 0 & $\overline{-}$ & $\overline{-}$ & 26.7 & 0 \\
\hline & & & & & & 10 & - & - & 24.1 & 5.5 \\
\hline & & & & & & 15 & - & - & 23.1 & 5.6 \\
\hline \multirow{3}{*}{\multicolumn{6}{|c|}{ Silt-Silt Interface }} & 0 & $\overline{-}$ & $\overline{-}$ & 30.2 & 0.6 \\
\hline & & & & & & 10 & - & - & 26.2 & 4.9 \\
\hline & & & & & & 15 & - & - & 22.3 & 12.2 \\
\hline \multirow{3}{*}{\multicolumn{6}{|c|}{ Clay-Clay Interface }} & 0 & $\overline{-}$ & - & 31.7 & 2.9 \\
\hline & & & & & & 10 & - & - & 29.4 & 9.6 \\
\hline & & & & & & 15 & - & - & 20.6 & 3.5 \\
\hline
\end{tabular}

*Value was calculated in laboratory. 


\subsection{Conclusions}

Conclusions drawn from direct shear tests and pullout tests are listed in this section. Conclusions from the comparison of direct shear and pullout test results are also included in this section.

\subsubsection{Conclusions for Direct Shear Test Results}

Conclusions drawn from direct shear testing are listed below.

- Angle of friction values for sand-geosynthetic interfaces are similar to the angle of friction values of the sand-sand interfaces, Table 5.1.

- Angle of friction values for sand-geosynthetic interfaces do not seem to be affected by the tensile strength of the geosynthetic, Table 5.1.

- Shear stress values at failure for material A and B interfaces typically increase as tensile strength decreases, Figures 4.49, 4.50 and 4.51.

- Angle of friction values typically increase as the percentage of clay in the soil increases, Table 5.1.

- Effective cohesion values typically increase as water content in the soil increases, Table 5.1.

\subsubsection{Conclusions for Pullout Test Results}

Conclusions drawn from pullout testing are listed below.

- Shear stress values at failure increase as the normal stress increases, Figures 4.52 through 4.111.

- Angle of friction values increase as the tensile strength of the geosynthetics increase, Table 5.1.

- Water content and soil type do not affect geosynthetic property influences, Figures 4.128 through 4.139 . 
- Angle of friction values typically decrease for soil-geosynthetic interfaces as the amount of clay in a soil increases, Table 5.1.

- Effective cohesion values typically increase as the amount of clay in a soil increases, Table 5.1.

- Shear stress values at failure typically decrease as the percentage of clay in the soil increases, Figures 4.113 through 4.127.

- The water content of the soil seems to have no effect on shear stress failure values when testing soil-material C interfaces, Figures 4.146, 4.147, and 4.148.

- Shear stress values at failure for soil-material A and soil-material B interfaces typically decrease as soil moisture content increases, Figures 4.140 through 4.145 and 4.149, 4.150 and 4.151.

\subsubsection{Conclusions for the Comparison of Direct Shear and Pullout Test Results}

Conclusions drawn from pullout vs. direct shear testing are listed below.

- The pullout angle of friction values decrease with tensile strength of the geosynthetic while direct shear angle of friction values remain relatively steady, Table 5.1.

- The pullout shear stress values at failure drop dramatically as the geosynthetic tensile strength decreases but the direct shear shear stress values at failure do not, Figures 4.155, 4.156 and 4.157.

- Shear stress failure values are less similar, for different normal stresses, in direct shear testing than pullout testing, Figures 4.152 through 4.157.

\subsection{Recommendations}

The following recommendations are made for future testing.

- Complete a study with the larger pullout device containing pullout box B. This will enable results from pullout box B to be compared with the results from 
pullout box A and the effects of specimen size and boundary conditions to be explored.

- Perform a computer modeling study to simulate laboratory tests using Finite Element method and compare these results with the laboratory results.

- Use additional geosynthetic materials in direct shear and pullout testing. This will allow the effects of geosynthetic material properties to be explored further. 


\section{REFERENCES}

Al-Qadi and Appea, 2003. “Eight-Year Field Performance of A Secondary Road Incorporating Geosynthetics at the Subgrade-Base Interface.” Proceedings of the 2003 Transportation Research Board Meeting, Washington, D.C.

Allen, T.M., Christopher, B.R., and Holtz, R.D., 1992. "Performance of a 12.6m High Geotextile Wall in Seattle, Washington.” Geosynthetic-Reinforced Soil Retaining Walls, Wu, J.T.H. Balkema Publishers, Rotterdam.

Alobaidi, I.M., Hoare, D.J. and Ghataora, G.S., 1997. “Load Transfer Mechanism in Pull-Out Tests.” Geosynthetics International, Vol. 4, No. 5, pp. 509-521.

Ashmawy, Cira, Gunaratne, and Lai, 2003. “Factors Controlling the Internal Stability and Deformation of Geogrid-Reinforced Bridge Abutments” Proceedings of the 2003 Transportation Research Board Meeting, D.C.

American Society for Testing and Materials (ASTM D-5321), 2001. "Standard Test Method for Determining the Coefficient of Soil and Geosynthetic or Geosynthetic and Geosynthetic Friction by the Direct Shear Method”. ASTM Standards in Building Codes, 38 ${ }^{\text {th }}$ Edition, Vol. 4, pp. 297-302, West Conshohocken, PA.

Bauer, G.E. and Zhao, Y., 1993. "Evaluation of Shear Strength and Dilatancy Behavior of Reinforced Soil from Direct Shear Tests.” Geosynthetic Soil Reinforcement Testing Procedures, ASTM STP 1190, S.C. Jonathan Cheng, Ed., American Society for Testing and Materials, Philadelphia.

Cazzuffi, D., Picarelli, L., Ricciuti, A., and Rimoldi, P., 1993. “Laboratory Investigations on the Shear Strength of Geogrid Reinforced Soils.” Geosynthetic Soil Reinforcement Testing Procedures, ASTM STP 1190, S.C. Jonathan Cheng, Ed., American Society for Testing and Materials, Philadelphia. 
Cleveland, G.S., Lytton, R. L., and Button, J.W., 2003. "Reinforcing Benefits of Geosynthetic Materials in Asphalt Concrete Overlays using Pseudo Strain Damage Theory." Proceedings of the 2003 Transportation Research Board Meeting, D.C.

Collin, J.G. and Berg, R.R., 1993. "Comparison of Short-Term and Long-Term Pullout Testing of Geogrid Reinforcements.” Geosynthetic Soil Reinforcement Testing Procedures, ASTM 1190, S.C. Jonathan Cheng, Ed., American Society for Testing and Materials, Philadelphia.

Dove, J.E., and Frost, J.D., 1999. "Peak Interface Friction Behavior of Smooth Geomembrane-Particle Interface”. Journal of Geotechnical Engineering, Vol. 125, No. 7. pp. 544-555.

Elias, V., Yuan, Z., Swan, Jr., R.H., and Bachus, R.C. (1998). “Development of Protocols for Confined Extension/Creep Testing of Geosynthetics for Highway Applications,” Report FHWA-RD-97-143, Federal Highway Administration.

Farrag, K., Acar, Y.B., and Juran, I., 1993. "Pull-Out Resistance of Geogrid Reinforcements.” Geotextiles and Geomembranes 12, pp. 133-159.

Farrag K. and Griffin, P., 1993. "Pull-out Testing of Geogrids in Cohesive Soils.” Geosynthetic Soil Reinforcement Testing Procedures, ASTM STP 1190, S.C. Jonathan Cheng, Ed., American Society for Testing and Materials, Philadelphia.

Gurung, N., 2000. “A Theoretical Model for Anchored Geosynthetics in Pull-Out Tests.” Geosynthetics International, Vol. 7, No. 3, pp. 269-284.

Gurung, N. and Iwao, Y., 1998. "Pull-out test analysis for geo-reinforcement." Geotextiles and Geomembranes 17, pp. 157-170 
Hori, K., Kishida, H., Tateyama, M. and Tatuoka, F., 1994. “Computerized Design Method for Geosynthetic-reinforced soil retaining walls for railway embankments.” Proceedings of the Seiken Symposium, Tokyo, Japan, A. A. Balkema Publishers, Rotterdam.

Ingold, T.S., 1994. The Geotextiles and Geomembranes Manual. Elsevier, UK.

Koener, R.M., 1998. Designing with Geosynthetics. Prentice-Hall, New Jersey.

Kutay, E.M, and Aydilek, A.H,. 2003. "Hydraulic Compatibility of Geotextile Drains with Fly Ash in Pavement Structures.” Proceedings of the 2003 Transportation Research Board Meeting, D.C.

Kuo, C. and Hsu, T., 2003. “Traffic Induced Reflective Cracking on Pavements with Geogrid-Reinforced Asphalt Concrete Overlay.” Proceedings of the 2003 Transportation Research Board Meeting, D.C..

Lopes, M.L. and Ladeira, M., 1996. "Role of Specimen Geometry, Soil Height and Sleeve Length on the Pull-Out Behavior of Geogrids.” Geosynthetics International, Vol. 3, No. 6, pp. 701-719.

Madhav, M.R., Gurung, N., and Iwao, Y., 1998. “A Theoretical Model for the Pull-Out Response of Geosynthetic Reinforcement.” Geosynthetics International, Vol. 5, No. 4, pp. 399-424.

Matsuoka, H., Liu, S., Sun, D., and Nishikata, U., “Development of a New In-Situ Direct Shear Test,” Geotechnical Testing Journal, GTJODJ, Vol. 24, No. 1, March 2001, pp. 92-102 
Miki, H., Kudo, K., Taki, M., Fukuda, N., Iwasaki, K, and Nishimura, J., 1994. “The facing's retaining effect of steep slope reinforced embankment,” Proceedings of the Seiken Symposium, Tokyo, Japan, A. A. Balkema Publishers, Rotterdam.

Moss, A.L. (1999). "Interfacial Shear Strength of Geosynthetics Using the Cylinder Direct Shear Test,” Utah State University, Logan, Utah.

Moss, A.L. and Anderson, L.R. (2000). “Cylinder Direct Shear: A New Test Method,” Geotechnical Special Publication, No. 103, pp. 106-116

Raju, D.M. and Fannin, R.J., 1997. “Monotonic and Cyclic Pull-out Resistance of Geogrids.” Geotechnique 47, No. 2, pp. 331-337.

Razaqpur, A.G., Bauer, G.E., Halim, A.O.A. and Zhao, Y., 1993. "Pullout Resistance and Load-Slip Response of Mechanically Damaged Geogrids.” Geosynthetic Soil Reinforcement Testing Procedures, ASTM STP 1190, Philadelphia.

Tatsuoka, F. and Leshchinsky, D., 1994. "Recent Case Histories of Permanent Geosynthetic-Reinforced Soil Retaining Walls,” Proceedings of the Seiken Symposium, Tokyo, Japan, A. A. Balkema Publishers, Rotterdam.

Tateyama, M., Murata, O., Watanabe, K. and Tatsuoka, F., 1994. “Geosyntheticsreinforced retaining walls for bullet train yard in Nagoya,” Proceedings of the Seiken Symposium, Tokyo, Japan, A. A. Balkema Publishers, Rotterdam.

Tingle, Jeb S. and Webster, Steve L., 2003. "Review of Corps of Engineers Design of Geosynthetic Reinforced Unpaved Roads.” Proceedings of the 2003 Transportation Research Board Meeting, D.C. 
Wathugala, G.W., Huang, B., and Pal, S., 1996. "Numerical Simulation of Geosynthetic-Reinforced Flexible Pavements.” Transportation Research Record 1534. 58-65.

Yuan, Z., Moore, J.K., and Swan Jr., R.H., 2003. "Pullout Resistance of Geogrid in Expanded Clay Lightweight Aggregate Material.” Proceedings of the 2003 Transportation Research Board Meeting, D.C. 